\title{
Cytomegalovirus mRNA transcripts and anti- cytomegalovirus antibodies as markers of the balance between cytomegalovirus and host immunity
}

Citation for published version (APA):

Goossens, V. J. (2003). Cytomegalovirus mRNA transcripts and anti-cytomegalovirus antibodies as markers of the balance between cytomegalovirus and host immunity. [Doctoral Thesis, Maastricht University]. Universiteit Maastricht. https://doi.org/10.26481/dis.20031030vg

Document status and date:

Published: 01/01/2003

DOI:

10.26481/dis.20031030vg

Document Version:

Publisher's PDF, also known as Version of record

Please check the document version of this publication:

- A submitted manuscript is the version of the article upon submission and before peer-review. There can be important differences between the submitted version and the official published version of record. People interested in the research are advised to contact the author for the final version of the publication, or visit the DOI to the publisher's website.

- The final author version and the galley proof are versions of the publication after peer review.

- The final published version features the final layout of the paper including the volume, issue and page numbers.

Link to publication

\footnotetext{
General rights rights.

- You may freely distribute the URL identifying the publication in the public portal. please follow below link for the End User Agreement:

www.umlib.nl/taverne-license

Take down policy

If you believe that this document breaches copyright please contact us at:

repository@maastrichtuniversity.nl

providing details and we will investigate your claim.
}

Copyright and moral rights for the publications made accessible in the public portal are retained by the authors and/or other copyright owners and it is a condition of accessing publications that users recognise and abide by the legal requirements associated with these

- Users may download and print one copy of any publication from the public portal for the purpose of private study or research.

- You may not further distribute the material or use it for any profit-making activity or commercial gain

If the publication is distributed under the terms of Article $25 \mathrm{fa}$ of the Dutch Copyright Act, indicated by the "Taverne" license above, 


\title{
Cytomegalovirus mRNA transcripts and
} anti-cytomegalovirus antibodies as markers of the balance between cytomegalovirus and host immunity

\author{
Valère J. Goossens
}



Cytomegalovirus mRNA transcripts and anti-cytomegalovirus antibodies as markers of the balance between cytomegalovirus and host immunity

\author{
PROEFSCHRIFT
}

Ter verkrijging van de graad van doctor

aan de Universiteit Maastricht, op gezag van de Rector Magnificus,

Prof. Dr. A. C. Nieuwenhuijzen Kruseman, volgens het besluit van het

College van Decanen, in het openbaar te verdedigen op

donderdag 30 oktober 2003 om 12.00 uur

door

Valère Joseph Goossens 


\section{Promotor}

Prof. Dr. C.A. Bruggeman

\section{Co-promotor}

Dr. M.H.L. Christiaans

\section{Beoordelingscommissie}

Prof. Dr. J.W. Cohen Tervaert (voorzitter)

Prof. Dr. R.A. Donckerwolcke

Dr. S. van der Geest

Prof. Dr. P. Goubau (Université Catholique Louvain-la-Neuve)

Prof. Dr. K.M. Leunissen

ISBN 90-5681-181-9 


\section{Contents}

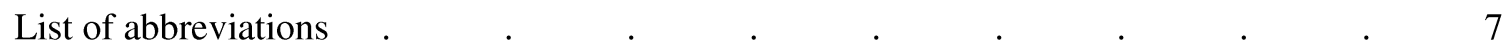

\section{CHAPTER 1}

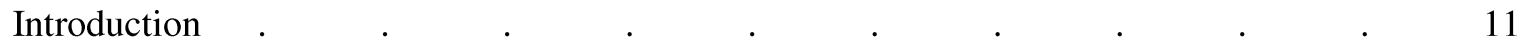

1.1 Cytomegalia in historical perspective . $\quad . \quad$. $\quad$. $\quad$. $\quad$. 11

1.2 Biology and structure of human cytomegalovirus $\quad . \quad$. $\quad$. $\quad$. $\quad$. 13

1.3 Viral replication and molecular biology of human CMV $\quad$. $\quad$. $\quad 15$

1.4 Clinical manifestations of human CMV infection _ . $\quad$. $\quad . \quad$. 17

1.5 Common CMV diagnostic procedures . $\quad . \quad$. $\quad$. $\quad . \quad$. $\quad 22$

1.5.1 CMV detection by conventional cell culture and/or DEAFF . . $\quad 22$

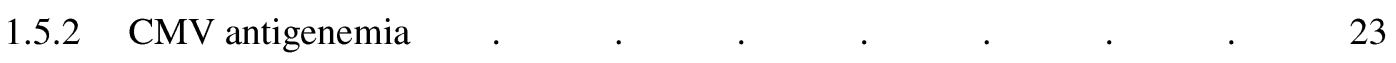

1.5.3 CMV DNA detection by PCR assays . . . . . . . . $\quad$. $\quad 23$

$\begin{array}{llllll}\text { 1.5.4 CMV mRNA detection by NASBA assays } \quad . \quad & \text {. } & \text {. } & 24\end{array}$

1.5.5 Immunological response to CMV infection . . . . . . 26

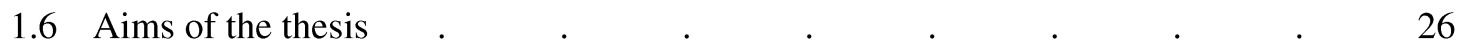

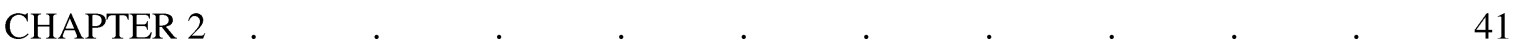

Early detection of cytomegalovirus in renal transplant recipients:

comparison of PCR, NASBA, pp65 antigenemia, and viral culture

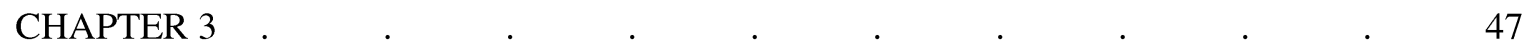

Diagnostic value of nucleic-acid-sequence-based amplification for the detection of cytomegalovirus infection in renal and liver transplant recipients 
Different profiles of cytomegalovirus RNA transcripts and

anti-cytomegalovirus $\operatorname{IgM}$ antibodies in renal transplant recipients

CHAPTER 5

Onset and duration of cytomegalovirus immediate early 1

mRNA expression in blood of renal transplant recipients

CHAPTER 6

A delay in CD4 cell response after initiation of highly active

antiretroviral therapy is associated with the presence of

anti-cytomegalovirus but not with anti-herpes simplex virus antibodies

\section{CHAPTER 7}

Summary, general discussion and conclusions

Samenvatting

Dankwoord / acknowledgments .

Curriculum vitae

Publications 


\section{List of abbreviations}

AG : antigenemia

AIDS : acquired immunodeficiency syndrome

AU/ml : antibody units per milliliter

BMT : bone marrow transplant

CID : cytomegalic inclusion disease

CMV : cytomegalovirus

CPE : cytopath(ogen)ic effect

D : donor

DEAFF : detection of early antigen fluorescent foci

ds : double stranded

E : early

EBV : Epstein-Barr virus

ELISA : enzyme-linked immunosorbent assay

$\mathrm{gB}:$ glycoprotein B

GCV : ganciclovir

HAART : highly active antiretroviral therapy

HCMV : human cytomegalovirus

HHV : human herpesvirus

HIV : human immunodeficiency virus

HSV : herpes simplex virus

ICS : internal calibration standard

IE : immediate early

IE1 : immediate early 1 (mRNA)

IF : immunofluorescent

Ig : immunoglobulin

$\mathrm{IR}_{\mathrm{L}}$ : internal long repeat sequence

$\mathrm{IR}_{\mathrm{S}}$ : internal short repeat sequence

ISC : internal system control

KSHV : Kaposi's sarcomaherpesvirus

L : late

LTx : liver transplant

MEIA : microparticle enzyme immunoassay

MIE : major immediate early

MMF : mycophenolate mofetil

mRNA : messenger RNA

NASBA : nucleic acid sequence-based amplification

NFkB : nuclear factor kappa B

NK : natural killer

NPV : negative predictive value

PBS : phosphate buffered saline

PCR : polymerase chain reaction

PI : protease inhibitor

PMN(L) : polymorphonuclear leukocytes

PPV : positive predictive value

$\mathrm{R}$ : receptor

$\mathrm{RT}$ : reverse transcriptase

RTx : renal transplant

SE : standard error of the mean

SGV : salivary gland virus

SOT : solid organ transplant

ss : single stranded

$\mathrm{TR}_{\mathrm{L}}$ : terminal long repeat sequence

$\mathrm{TR}_{\mathrm{S}}$ : terminal short repeat sequence

UL : unique long domain

US : unique short domain

$\mathrm{VC}$ : viral culture

VZV : varicella zoster virus 
Chapter 1

INTRODUCTION 



\section{Introduction}

The herpesviruses belong to a large family of DNA viruses and there are well over 100 identified herpesviruses [126]. Herpesviruses are characterized by a worldwide occurrence. Infections with these viruses have been described in almost all animal species and the host range spans the whole spectrum of warm- and cold-blooded vertebrates and invertebrates.

For the human host, there are at least eight known herpesviruses: herpes simplex virus (HSV)-1, HSV2, varicella zoster virus (VZV), cytomegalovirus (CMV), Epstein-Barr virus (EBV), human herpesvirus (HHV)-6, HHV-7, and Kaposi's sarcomaherpesvirus (KSHV) or HHV-8. They are grouped into three subfamilies based on viral characteristics and pathogenesis. The alpha herpesvirus subfamily comprises HSV-1, HSV-2 and VZV, the beta herpesvirus subfamily comprises CMV, HHV-6 and HHV-7 while EBV and HHV-8 represent the gamma herpesviruses. Herpesviruses vary largely in their biological properties. Some, like HSV-1 and HSV-2, have a wide host cell range, have a high multiplication rate and rapidly destroy infected cells, while others, like CMV, have a narrow host cell range, multiply slowly, remain cell associated for a long period and the infected cells frequently become enlarged (cytomegalia). Although all herpesviruses remain latent in a specific set of cells, the exact cell in which they remain latent varies from one virus to another. For example, HSV-1, HSV-2 and VZV remain in neurons during latency while EBV establishes latency in B-lymphocytes [127]. Cytomegalovirus can be maintained in latent form in secretory glands, lymphoreticular cells, kidneys, and other tissues [127].

\subsection{Cytomegalia in historical perspective}

Large inclusion-bearing cells (now known as a typical effect of CMV infected cells) were first documented by Ribbert [120] who observed them in the kidneys of a stillborn infant with syphilis in 1881. He described the inclusion as a homogeneous body in the nucleus that was separated by a clear area from the nuclear membrane. His observation was not reported until 1904, when the first illustrations of these 'protozoan-like' cells in the kidneys, lungs, and liver of another stillborn infant with syphilis were published by Jesionek [74]. In the viscera of these infants, large cells with a 20-30 $\mu \mathrm{m}$ diameter and prominent intranuclear inclusion bodies were described. This unusual histopathological change is now recognized as being caused by CMV. In 1904 however, it was assumed that the large inclusion-bearing cells observed at autopsy was from a protozoa (incorrectly named Entamoeba mortinatalium). In 1905, 'protozoan-like' cells were also described in parotid tissue removed from a 4-month-old infant [158].

In 1921, Goodpasture [47] introduced the term 'cytomegalia' to describe these enlarged cells. He also concluded that, within these enlarged cells, protozoan parasites were not present. In addition, he also noted that the microscopic nuclear changes resembled those described in varicella skin lesions [47]. Also in 1921, Lipschutz [91] reported that similar inclusions were associated with lesions in humans and rabbits infected with herpes simplex. A viral aetiology of 'cytomegalia' was postulated in 1925 in a study of similar cells from the viscera of an adult [162]. Confirmation of the viral aetiology of 'cytomegalia' was found already in 1926. At that time, Cole demonstrated that a filterable agent was present in salivary gland tissue from a guinea pig positive for intranuclear inclusions. Even after filtration through a Berkefeld $\mathrm{N}$ filter, this agent retained its infectivity and induction of 'cytomegalia', indicating viral activity [27].

Isolation of the causative virus had not been accomplished for an additional three decades. However, around 1956, isolation of the host-specific virus was described independently by three American groups of workers [172]. Margaret G. Smith of St Louis, Michigan, USA, first propagated a murine virus from salivary gland tissue [143] and then isolated a virus from humans in tissue culture [144]. 
Initial isolation of the human virus was also achieved by Thomas H. Weller and co-workers in Boston, Massachusetts, USA, and by W.P. Rowe and co-workers of Bethesda, Maryland, USA (table 1).

It is not so well known that, already early in the fifties, Smith had obtained an agent from human uterine cell culture inoculated with salivary gland material of an infant and carried it for more than a dozen passages [67]. The lesions produced were similar to those produced by the mouse salivary gland virus, but the human agent did not grow in mouse tissue, and the mouse CMV did not grow in human tissue. Smith's paper describing her findings was rejected by a journal on the incorrect ground that she might have been growing the mouse agent in human tissues. It was not until 1954, after Smith reisolated human CMV from the salivary gland of one dead infant and from the kidney of another infant who had died of cytomegalic inclusion disease, that her paper was accepted and published in 1956 [144].

In January 1955, a microcephalic 3-month-old infant with hepatosplenomegaly, cerebral calcification and chorioretinitis was admitted to the Children's Hospital in Boston. A liver biopsy was undertaken and cultures of human embryonic skin-muscle tissue were inoculated with a suspension of the liver tissue. By day 12, Weller and co-workers [170] observed within these cultures focal collections of swollen, rounded translucent cells which later contained refractile pigment granules. The foci produced by the virus (termed the Davis strain) increased in size and number. Subcultures of this micro-organism could be easily obtained and, when stained, intranuclear inclusions were prominent in the swollen cells thereby confirming that the first isolation of the causative virus from an infant surviving cytomegalic inclusion disease (CID) had achieved.

Shortly thereafter, Rowe and his co-workers, working on adenoviruses, isolated three viruses that were different from adenoviruses in that they induced large, intranuclear inclusions in cultured human fibroblasts. The cytopathic changes in cultures of this agent, termed AD169, were similar to those produced by the Davis strain. Rowe et al. [129] then described the isolation of the AD169 agent as resembling 'salivary gland virus' (SGV). Their development of a complement fixation reaction with the AD169 virus was an important contribution, since it established a high prevalence of past infection with CMV in adults.

By 1960, agents termed 'salivary gland virus (SGV)' or 'cytomegalic inclusion disease virus' were being propagated by several groups. Comparing the capacity of sera from patients with CID to neutralize both CID virus and the SGV agent, antigenic variations were detected. Weller et al. [171] reacted sera from two babies (named Davis and Esp.) with isolates from themselves, with isolates from each other, and with Rowe's isolate from adenoids AD169. The homologous serum-virus pairs produced the highest titer. Serum from Davis did not neutralize the Esp. and AD169 isolates, whereas it neutralized the Davis isolate at a high dilution. Later on, with this antigenic diversity in mind, and because the human virus was not confined to the salivary glands, the term 'cytomegalovirus' was proposed by Weller and is still in use [171]. While it is now established that different strains vary in the nature of their cytopathic activity in vitro, an unanswered question is whether or not they also vary in terms of their pathogenicity in vivo.

Parenthetically, CMV and Pope John Paul II even reached the New York Times in June 1981 [105]. Following an assassination attempt at May $13^{\text {th }} 1981$, the pope underwent emergency surgery including splenectomy. After receiving 10 transfusions, the pope developed persistent fever, pneumoniae with respiratory failure, liver failure and nearly died as a result of transfusion-transmitted CMV infection. 


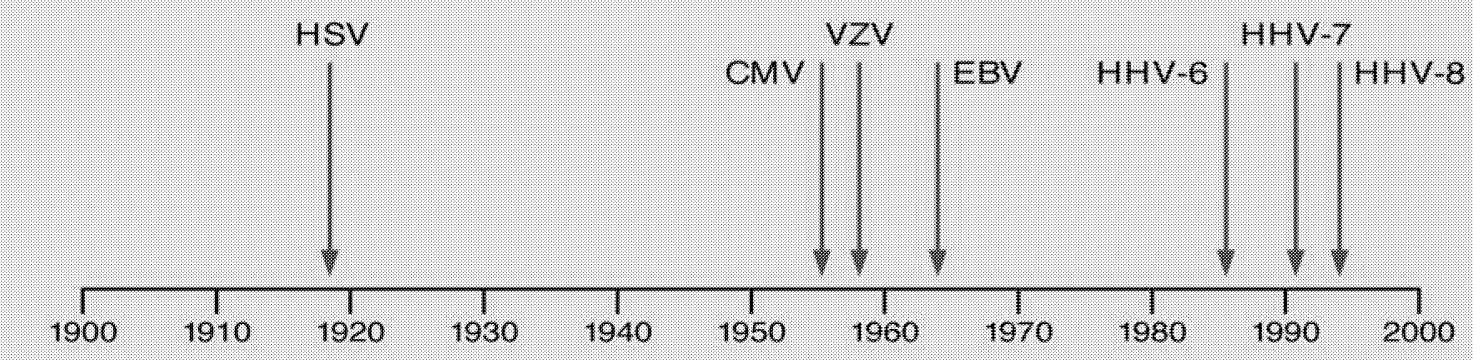

\section{Fig. 1. First detection of human herpesviruses}

For a graphical overview of the first detection of CMV and the other herpesviruses, see fig. 1. Note that, after detection of HSV that was already achieved in 1918, CMV was detected as second member of the group of herpesviruses and that isolation of most of the human herpesviruses is from recent date.

Table 1: Laboratory strains of human CMV

\begin{tabular}{|l|l|l|}
\hline $\begin{array}{l}\text { Name of } \\
\text { CMV strain }\end{array}$ & Origin (of first isolation) & Reference \\
\hline AD169 & $\begin{array}{l}\text { Tonsillectomy-adenoidectomy, } \\
\text { 7-year-old girl }\end{array}$ & 129,176 \\
\hline Colburn & Brain biopsy of a 6-year-old boy with clinical encephalopathy & 106 \\
\hline Davis & $\begin{array}{l}\text { Liver biopsy, 3-month-old girl with microencephaly and other } \\
\text { symptoms resembling congenital toxoplasmosis }\end{array}$ & 170,171 \\
\hline Esp. & Urine of living infant suspected of suffering from C.I.D. & 171 \\
\hline Kerr & Urine of living infant suspected of suffering from C.I.D. & 171 \\
\hline Merlin & Urine of congenitally infected infant & 178 \\
\hline T-27 & & 2 \\
\hline TB40 & Troat swab of a bone marrow transplant recipient & 180 \\
\hline Toledo & & 115 \\
\hline Towne & Urine, man with congenital cytomegalic inclusion disease & 113 \\
\hline VHL & & 181 \\
\hline
\end{tabular}

In the American Type Culture Collection, the AD169 strain, the Davis strain and the Towne strain are deposit as strain VR-538, VR-807 and VR-977 respectively.

\subsection{Biology and structure of human cytomegalovirus}

Human CMV that is a member of the human herpesvirus family is designated as human herpesvirus 5 (HHV-5). CMV is the largest member of the herpesvirus family. For a graphic presentation of the CMV morphology, see fig 2. As with the other herpesviruses, the structure of the viral particle is that of a DNA-containing core in a $100-\mathrm{nm}$ diameter icosahedral capsid that is surrounded by a tegument or matrix [96, 174]. The capsid and the tegument are enclosed in a lipid bilayer outer envelope carrying a number of virally encoded glycoproteins. Mature virions range in size from 150 to $200 \mathrm{~nm}$ [174]. 
The outer envelope of the virus, which is derived from the host cell nuclear membrane, contains multiple virally encoded glycoproteins. Of these envelope proteins, CMV glycoprotein B $(\mathrm{gB})$, or gpUL55 [89], is the major envelope glycoprotein of CMV [44] and up to $50 \%$ of the protein mass of the viral envelope is represented by $\mathrm{gB}$. CMV $\mathrm{gB}$ is a $150-\mathrm{kd}$ multifunctional glycoprotein that is likely to play a role in virion penetration into cells, transmission from cell to cell, fusion of infected cells $[104]$ and is a prominent target for the neutralizing antibody response $[23,32,108,109]$. As is true for other herpesvirus $\mathrm{gB}$ homologs, $\mathrm{CMV} \mathrm{gB}$ is an essential gene and strains lacking gB cannot be propagated [179]. Anti-gB monoclonal antibodies with neutralizing activity block CMV infection at the level of virus entry [104] and a soluble form of CMV gB blocks virus entry and infection [175]. However, although humoral responses are important in control of disease, they clearly are inadequate in preventing transplacental infection, which can occur even in women who are CMV-seropositive. DNA sequence analysis has revealed four distinct CMV gB genotypes [184].

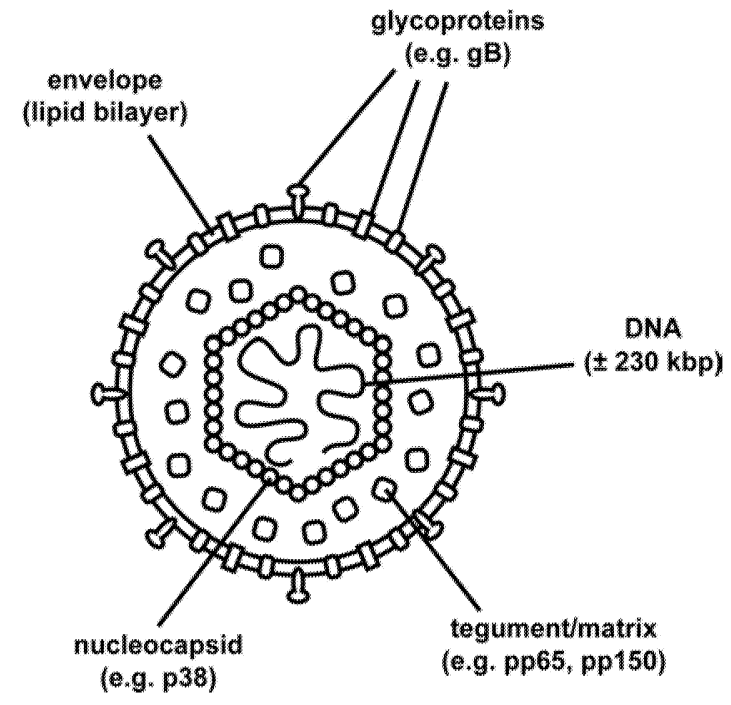

Fig. 2. Graphic presentation of CMV morphology

The viral tegument, a proteinaceous layer between the envelope and the inner capsid, is constituted of about 20 proteins. These viral proteins that anchor the envelope to the inner capsid are referred to as matrix proteins with pp65 (ppUL83) and pp150 (ppUL32) as major representatives. Pp65, or the lower matrix protein, is one of the most extensively studied proteins. It is of special importance in the diagnostic setting. During active infection pp65 is detectable in nuclei of polymorphonuclear cells [50, 87]. The development of the CMV-pp65 antigenemia method enables the early and rapid diagnosis of CMV infection [160]. In vitro, pp65 is abundantly produced in infected fibroblasts. The expression level of pp65 in infected cells is lower if low-passage clinical strains are used [72]. Furthermore, infection by a low multiplicity of the virus results in less production of pp65 [77]. In infected cells, pp65 is the major phosphate acceptor [21, 125] and has kinase activity [137], and autophosphorylation capacity [137]. After viral entry pp65 is immediately translocated to the nucleus [87]. In the nucleus pp65 can bind to metaphase chromosomes, but pp65 has no DNA binding capacity [33]. During viral replication pp65 is located in specific nuclear compartments [134]. Although pp65 is not required for viral replication in vitro [137], viral replication is markedly reduced in its absence. Pp150 or basic phosphoprotein is another phosphate acceptor in the tegument, it is incorporated preferentially into virions rather than dense bodies, and is estimated to make up about $20 \%$ of the virion mass [182]. Acquisition of pp150 starts in the nucleus [65]. Experiments with antisense pp150 mRNA reveals an essential role for this protein in late stage virus maturation [97].

The inner capsid or nucleocapsid is approximately $100 \mathrm{~nm}$ in diameter and is composed of 162 capsomers. Gibsen et al. provided the initial characterization of the protein constituents of the CMV 
capsids [43, 44, 70, 71]. One of these is a nonstructural phosphoprotein of 37 to $45 \mathrm{kd}$, called B-capsid assembly protein $[45,71,124]$, and is derived from the carboxyl-terminal half of human CMV UL80 (UL80A) by an autocatalytic protease $[124,135,169]$. In addition to a role in maturation, the B-capsid assembly protein remains associated with an alternative capsid form that matures as noninfectious enveloped particles $[70,71]$.

Table 2 gives an overview of immunogenic human CMV proteins that are subject of this thesis.

Table 2: Description of important immunogenic human CMV proteins and their function/activity.

\begin{tabular}{|c|c|c|c|c|c|}
\hline Gene & Protein & Description & Localization & Function/activity & References \\
\hline UL32 & pp150 & $\begin{array}{l}\text { Basic } \\
\text { phosphoprotein }\end{array}$ & Tegument & Virus maturation & $\begin{array}{l}65,67,97,103, \\
182\end{array}$ \\
\hline UL55 & $\mathrm{gB}$ & $\begin{array}{l}\text { Major envelope } \\
\text { glycoprotein }\end{array}$ & Envelope & $\begin{array}{l}\text { Virion penetration in cells; } \\
\text { Transmission from cell to } \\
\text { cell; } \\
\text { Fusion of infected cells }\end{array}$ & $\begin{array}{l}44,58,67,89, \\
103,104,175, \\
179\end{array}$ \\
\hline UL65 & pp67 & & Tegument & & 103,192 \\
\hline UL80A & pp38 & $\begin{array}{l}\text { B-capsid } \\
\text { assembly } \\
\text { protein }\end{array}$ & Nucleocapsid & Virus maturation & $\begin{array}{l}45,58,70,71, \\
103,124,135, \\
169\end{array}$ \\
\hline UL83 & pp65 & $\begin{array}{ll}\begin{array}{l}\text { Lower } \\
\text { protein }\end{array} & \\
\end{array}$ & Tegument & $\begin{array}{l}\text { Phosphate acceptor; } \\
\text { Kinase activity; } \\
\text { Auto-phosphorylation } \\
\text { capacity; } \\
\text { Chromosome-binding }\end{array}$ & $\begin{array}{l}4,21,33,67, \\
103,110,111, \\
125,137,157, \\
160\end{array}$ \\
\hline UL123 & $\begin{array}{l}\text { pp72 } \\
\text { IE1 }\end{array}$ & $\begin{array}{l}\text { Immediate } \\
\text { early } 1 \text { protein }\end{array}$ & & Transcription regulator & $58,67,103$ \\
\hline
\end{tabular}

\subsection{Viral replication and molecular biology of human CMV}

The DNA-containing core of CMV consists of a double-stranded DNA genome of 230 kilobase pairs, capable of encoding more than 200 potential protein products. In 1990, the complete DNA sequence of AD169, with a total genome size of 229354 base pairs and 189 unique potentially protein-coding genes, was published by Chee and colleagues [176]. Although the function of most of these proteins remains unclear, an understanding of the process of viral replication provides insights into molecular mechanisms of antiviral therapy and protective immunity. CMV replicates very slowly in cell culture, mirroring its very slow pattern of growth in vivo.

The genome of CMV is linear and is composed of a unique long domain (UL) and a unique short (US) domain. Both ends of these domains are flanked by a repeat sequence, an internal and terminal long repeat sequence and an internal and terminal short repeat sequence, $\mathrm{IR}_{\mathrm{L}}, \mathrm{TR}_{\mathrm{L}}$, and $\mathrm{IR}_{\mathrm{S}}, \mathrm{TR}_{\mathrm{S}}$ respectively. The UL domain and US domain can be arranged head to tail or head to head and in the order UL-US or US-UL. In this way, four different isomers of the human CMV genome can be formed $[102,103]$. As with many viruses, small parts of DNA, not directly necessary for replication in vitro can be lost after serial propagation [153]. For example, the laboratory CMV strain AD169 as well as the low-passage clinical isolate Toledo had lost a part of the CMV genome compared to clinical isolates; AD169 misses a region of about $15 \mathrm{kbp}$ representing at least 19 genes and Toledo misses a region of about $13 \mathrm{kbp}$ [26]. Both regions are located in the same part of the viral genome. 
Initial events of the virus growth cycle in infected cells consist of attachment of CMV to the cell surface followed by penetration into the cell. Attachment proceeds rapidly and efficiently in both permissive and nonpermissive cells, suggesting that the receptor(s) for CMV are widely distributed on many different cell types $[38,41,121,142]$. Attachment to the cell surface is followed by penetration, even within 5 minutes of exposure to virus [141]. This virus entry is $\mathrm{pH}$ independent and occurs by direct fusion of the viral envelope with the host cell membrane [29]. Heparan sulfate proteoglycans have been reported to serve as primary attachment sites for CMV [177].

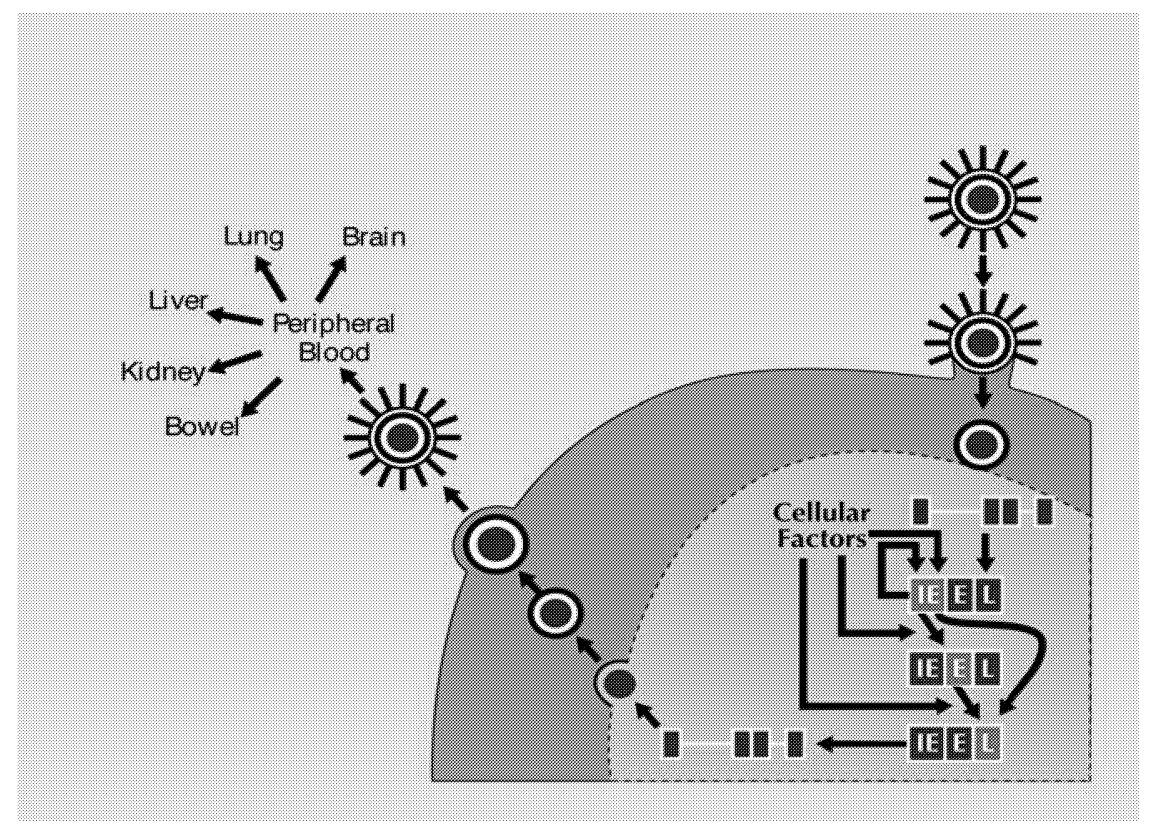

Fig. 3. Virus growth cycle with attachment to and penetration into infected cells, immediate early (IE), early $(E)$ and late $(L)$ gene transcription, assembly of new virions and dissemination into the blood and target tissues.

After entering of CMV into the host cell, the replication cycle of CMV is regulated in 3 phases: the immediate early, early and late phase ultimately resulting in the production of new virus particles leaving the infected cell (fig 3). Immediate early (IE) gene transcription occurs in the first 4 hours following entry of the virus in the cell and includes the major IE genes UL123/122 (IE1/IE2) and auxiliary IE genes, such as UL36 to UL38, UL155 to UL119, IRS1/TRS1, and US3. In contrast to transcription in the early and late phases, the transcription of immediate early genes does not depend on de novo protein synthesis. The major immediate early promoter of this region of the CMV genome is, due to the concentration of binding sites for NFkB as for other cellular transcription factors, one of the most powerful eukaryotic promoters described in nature. This unusually strong activity has been exploited in modern biotechnology as a useful promoter for driving gene expression in gene therapy and vaccination studies. The proteins encoded by the immediate early genes, e.g. immediate early 1 $(72 \mathrm{kd})$ and immediate early $2(86 \mathrm{kd})$ are important regulators of transcription of viral early genes. IE1 expression continues troughout infection, whereas IE2 expression decreases during the early phase of infection and rises again late in infection $[188,190]$. Although it is IE2 that is likely to be the major regulatory protein for viral early and late gene expression, IE1 functions as an accessory protein and IE2 acts more effeciently in the presence of IE1 [187, 189]. IE1 plays a positive feed-back role in activation of IE1/IE2 promoter-enhancer expression [186] and directly influences gene expression via a number of different transcription factors, including NFkB [183, 185, 191]. Expression of early CMV proteins results in more transcription factors and enzymes, among them the DNA polymerase. Finally, the late gene products are made approximately 24 hours after infection, and these proteins are mainly structural proteins that are involved in virion assembly and egress. Production of new infectious viral 
particles as in acute CMV infection requires the production of subsequently immediate early, early and late gene products. Synthesis of late gene products is highly dependent on viral DNA replication and can be blocked by inhibitors of viral DNA polymerase, such as ganciclovir (GCV). During latency, no new infectious viral particles can be detected, despite genomic CMV DNA is present.

Nevertheless, during CMV latency, similar as in a step model for HSV latency [82], CMV infected cells may express IE mRNA and their protein products but at levels insufficient for early gene expression [155]. However, when perturbated during reactivation, IE gene expression may be upregulated such that some early gene products may be synthesized $[139,156]$. Some cells may accumulate sufficient early mRNAs to threshold levels to permit DNA replication and some late gene expression. This may result in few infectious virions which initiate infection in new cells, leading to the lytic cascade and production of viral particles. Evidence has accumulated that human CMV remains latent in lineage-committed myeloid cells, including progenitors that give rise to granulocytes, macrophages, and dendritic cells [59, 139, 147], and possibly endothelial cells [140]. In latently infected progenitor cells, viral gene expression is restricted to sense and/or antisense latencyassociated transcripts that have been observed in both natural and experimental infection [59, 78, 79].

Recent investigations into the molecular biology of CMV have revealed the presence of many viral gene products, which appear to modulate host inflammatory and immune responses. Even during immediate early gene expression, CMV can efficiently block the presentation of immediate early antigens, the first viral proteins to be produced. The CMV genome encodes at least 4 genes involved in downregulating surface expression of HLA class I molecules. In addition, it sequesters CC chemokines, induces Fc receptors, interferes with induction of HLA class II antigens, and can inhibit natural killer cell activity. Together, these mechanisms probably contribute to the ability of CMV to persist in its host and may play a role in the immunopathology of CMV disease [100].

\subsection{Clinical manifestations of human CMV infection}

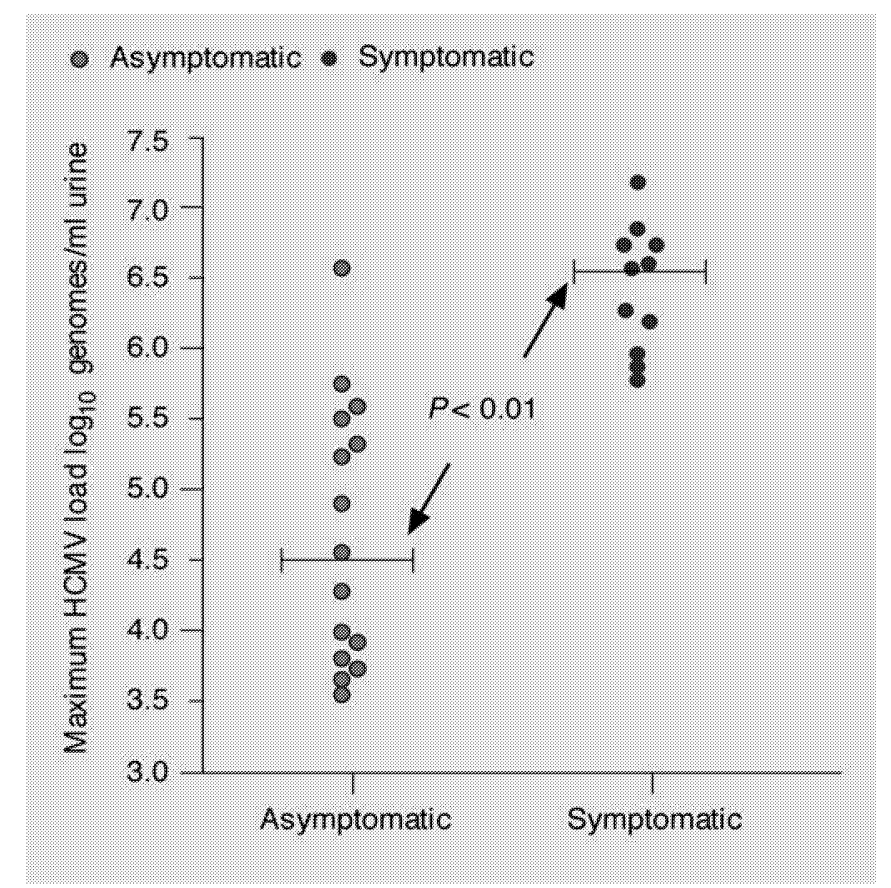

Fig. 4. Correlation of urinary CMV load with clinical disease in renal transplant recipients. 
In table 3 an overview of clinical manifestations of human CMV infection is given.

Primary infection occurs when the host acquires human CMV for the first time and mounts an immune response. In normal immunocompetent and healthy subjects most CMV infections are asymptomatic. Only occasionally, a CMV-associated syndrome of fever, abnormal values on liver function tests, and atypical lymphocytosis will develop [152]. This 'CMV mononucleosis', with symptoms similar to those of EBV induced mononucleosis, was first described by Kaariainen et al. [76] and is also known as the postperfusion syndrome occurring after blood transfusions.

More recently, CMV has emerged as an important opportunistic infection of hosts with impaired cellular immunity [62]. There is evidence that during a period of impaired immunity, the quantity of CMV in blood and in other body fluids, e.g. urine (fig. 4) increases and correlates with the likelihood of developing disease. Data suggest that the probability of CMV disease increases dramatically when viral load reaches a certain threshold. A graphical representation of how certain thresholds of viral replication could lead to viraemic spread and pathology [58] is shown in fig. 5. The analogy used is two baths with represent local and target organs for CMV replication. The tap represents production of virus, the plughole represents the immune system, and the overflow represents the viraemic spread in the case of local replication or pathological manifestations of CMV replication in the target organs. In the context of the renal transplant recipients, local infection within the kidney could reach a level which exceeds the level controlled by the immune system and hence allows viraemic spread of infection to other target organs. Therefore, viraemia is associated with increased viral disease since virus will be disseminated to multiple target organs. Within the target organ, the immune system can again control the level of replication. If the threshold viral load is exceeded in this target organ, then it may set in train a series of events leading to pathological consequences either through direct viral replication or through immunopathologic mechanisms.

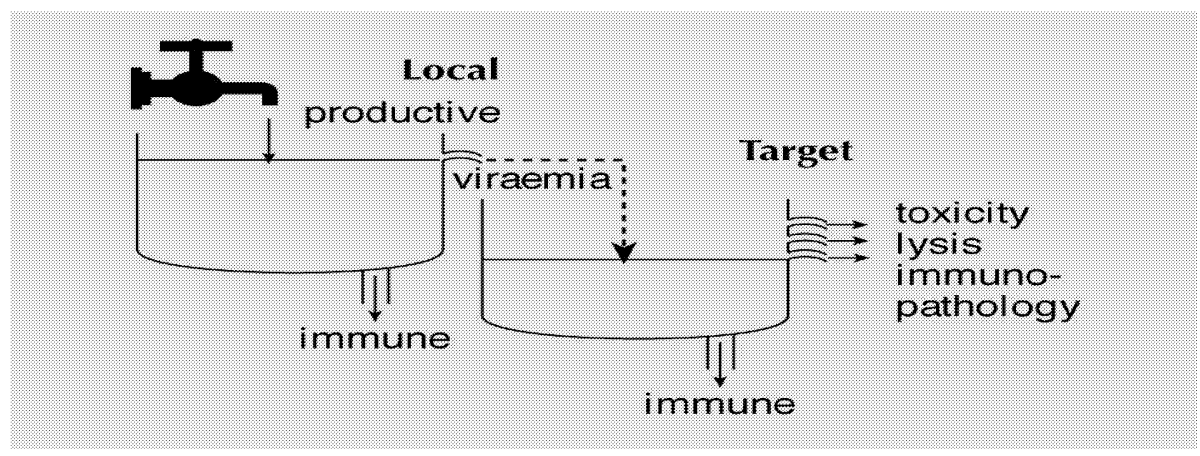

Fig. 5. Schematic representation of the threshold theory of how viral replication may lead to pathological consequences.

A special group of immunocompromised patients are the unborn children. The immune system of unborn children is immature in several aspects compared with that in adults. Overall, $T$ cell function, B cell function, the function of Natural Killer (NK) cells, and phagocytic defences are impaired in the fetus and partly also in the neonate [118]. Between $0.2 \%$ and $2.2 \%$ of infants born in the United States are infected by CMV in utero [149]. In European countries, screening of neonates for congenital CMV infection showed an overall incidence between $0.1 \%$ and $1 \%[1,3,7,49,56,60]$. The incidence is higher in younger mothers in which the CMV seroprevalence is lower and the risk for primary CMV infection is higher [3]. The clinical findings associated with intrauterine infection can vary from mild disease, with symptoms of hepatosplenomegaly, thrombocytopenia, petechia, microcephaly, chorioretinitis, and hepatitis, to severe life-threatening organ dysfunction with mortality rates of $11 \%$ to $20 \%$ [24]. Another $8 \%$ to $60 \%$ become infected during the first 6 months of life as 
result of infection acquired during birth or following breast-feeding [119, 148]. Clinical findings associated with CMV infection during or after birth in non-premature babies are usually mild.

In addition to the CMV mononucleosis syndrome, congenital CMV infections and perinatal CMV infections, CMV produces several other clinical entities. CMV is a major cause of interstitial pneumonia in individuals who are immunosuppressed because of congenital immunodeficiency, acquired immunodeficiency syndrome (AIDS), organ or bone marrow transplantation, or malignancy [35]. Pneumonia can also occur in apparently immunocompetent infants with perinatally acquired CMV infection [35].

Chorioretinitis occurs in $17 \%$ to $41 \%$ of newborns with symptomatic congenital CMV infection. In the 1980s, CMV retinitis emerged as a common manifestation of CMV disease in patients with severe immunosuppression, especially bone marrow transplant recipients and AIDS patients [35].

CMV hepatitis in recipients of bone marrow, lung, or heart transplants, patients with malignant disease or AIDS, or healthy individuals with a primary CMV infection is usually manifested by mild hepatic enlargement and mild elevation of serum liver enzyme levels accompanied by fever and lymphopenia or lymphocytosis. Jaundice and hyperbilirubinemia usually do not occur, and severe hepatitis or cirrhosis are rare. Hepatic necrosis and liver failure due to CMV hepatitis have not been well documented $[35,68,168]$

Gastrointestinal disease causing esophagitis, gastritis, gastroenteritis, small bowel obstruction, colitis, proctitis, pancreatitis, and haemorrhage have been associated with CMV infection in immunocompromised patients, especially patients with AIDS and those who have had bone marrow, renal, or liver transplantation [68].

Central nervous system involvement is well known in congenital CMV infections [61]. Postnatally, CMV meningoencephalitis appears to be rare, yet well documented [35]. There is growing recognition of CMV encephalitis in patients with AIDS. Up to $50 \%$ of such patients may show evidence of CMV infection of the central nervous system at autopsy [35].

Myocarditis has been described as a rare complication of both congenital CMV disease and the CMV mononucleosis syndrome. Myocarditis has also been seen in renal and heart transplant recipients [35].

Evidence of involvement of the organs of the endocrine system is well described in both congenital and postnatally acquired disseminated CMV infections. Involvement of the adrenal, pituitary, thyroid, and parathyroid glands has been encountered.

Cutaneous manifestations of CMV infections are uncommon but have been described. These are most notable in infants with symptomatic congenital infection who exhibit nonpalpable petechiae or purpura, usually as a result of thrombocytopenia [35].

In addition to the direct end-organ diseases caused by CMV, this virus is associated statistically with graft rejection, accelerated atherosclerosis and infectious complications, collectively termed the 'indirect effects' of CMV [130, 180]. Graft rejection is a common phenomenon across organ groups, the incidence of which varies according to organ type. At 5 years post-transplantation, the incidence of chronic rejection in liver transplants is $5-10 \%$ [12, 13, 173], but can be as high as $25-60 \%$ in heart transplants $[5,9,11,31,66,107], 40-50 \%$ in renal transplants $[8,25]$ and $50-60 \%$ in lung transplants $[52,63,64,98,154,167]$. In each organ type, characteristic pathological features are intimal proliferation and occlusion resulting in vanishing bile duct in liver transplants, in coronary artery disease in heart transplants, in glomerular sclerosis and tubular epithelial cell atrophy in renal transplants, and in obliterative bronchiolitis in lung transplants. The underlying pathophysiological process is that of atherosclerosis, involving injury, inflammation, cellular infiltration, degeneration and 
thrombosis. It is possible that CMV triggers the biological and biochemical cascade which leads to chronic graft rejection. The following effects of CMV may contribute: alteration of vascular smooth muscle cell growth, alteration of lipid metabolism, alteration of cytokines and their mediators, procoagulant effect, infection and alteration of leukocyte phenotype and function, activation of leukocytes to express maladaptive responses. Other studies have also shown that CMV infection or disease is a significant risk for acute rejection in recipients of cardiac [39, 92], pulmonary [6], renal $[19,40,95,117]$, liver [40] or solid organ transplant recipients [69].

Infectious complications in the early post-transplant period, such as fungal infections, are major barriers to treatment success and have a high mortality rate due to both diagnostic and therapeutic difficulties. CMV disease is a strong independent risk factor for invasive fungal disease and parasitic infections [145] in transplant recipients. This was confirmed by multivariate analysis $[42,159]$ and placebo-controlled ganciclovir [166] and CMV Ig [146] trials. The mechanism by which CMV infection could facilitate such infections remains speculative. The virus may disrupt integumentary surfaces in the lung, predisposing to superinfection, or it may cause alteration in humoral and cellmediated immunity $[37,93,114,138]$.

Recent reports indicate that additional groups of patients with more subtle immune defects, such as intensive care patients and cancer patients receiving chemotherapy, are at increased risk of developing symptomatic CMV infection [73, 84].

As mentioned previously, HIV infection and its immunosuppression as expressed by decreased CD4 cells, is an important predisposing factor for development of CMV disease. Besides this interaction between HIV-1 and CMV, also an interaction between CMV and HIV-1 has been demonstrated in numerous epidemiological, pathological and in-vitro molecular studies as listed by Kovacs [80] and reviewed by Griffiths [57]. In addition, various studies have demonstrated that CMV infection is associated with a more rapid progression of HIV-disease [20, 36, 131]. However, there are conflicting data as to whether or not this adverse effect of CMV is mediated via a more rapid loss of CD4 cells.

Table 3: Clinical manifestation of human CMV infection in different subgroups of patients at risk, e.g. AIDS-patients, bone marrow transplant recipients (BMT), solid organ transplant recipients (SOT) and intrauterine infected children with cytomegalic inclusion disease (CID). 


\begin{tabular}{|c|c|c|c|}
\hline $\begin{array}{l}\text { Involved } \\
\text { tract/organ/tissue }\end{array}$ & Clinical manifestation & Patients predominantly at risk & References \\
\hline Asymptomatic & None & $\begin{array}{l}\text { Normal healthy and } \\
\text { immunocompetent subjects }\end{array}$ & $24,58,67$ \\
\hline $\begin{array}{l}\mathrm{CMV}- \\
\text { mononucleosis }\end{array}$ & $\begin{array}{l}\text { Fever } \\
\text { Lymphadenopathy } \\
\text { Pharyngitis } \\
\text { Rash }\end{array}$ & $\begin{array}{l}\text { Normal healthy and } \\
\text { immunocompetent } \\
\text { adolescents/adults }\end{array}$ & $\begin{array}{l}24,58,67,76 \\
105,152\end{array}$ \\
\hline Respiratory & Pneumonitis & $\begin{array}{l}\text { BMT } \\
\text { SOT }\end{array}$ & $\begin{array}{l}24,35,58,67, \\
168\end{array}$ \\
\hline Eye & $\begin{array}{l}\text { Optic atrophy } \\
\text { Retinitis }\end{array}$ & $\begin{array}{l}\text { AIDS } \\
\text { CID }\end{array}$ & $24,35,58,67$ \\
\hline Ear & $\begin{array}{l}\text { Deafness } \\
\text { Hearing loss }\end{array}$ & CID & $24,58,67$ \\
\hline Gastrointestinal tract & $\begin{array}{l}\text { Colitis } \\
\text { Esophagitis } \\
\text { Gastritis } \\
\text { Haemorrhage } \\
\text { Perforation } \\
\text { Proctitis } \\
\text { Ulcerations } \\
\text { Vasculitis }\end{array}$ & $\begin{array}{l}\text { AIDS } \\
\text { BMT } \\
\text { SOT }\end{array}$ & $24,58,67,68$ \\
\hline Liver & Hepatitis & Liver transplant recipients & $\begin{array}{l}24,35,58,67 \\
68,168\end{array}$ \\
\hline Pancreas & Pancreatitis & $\begin{array}{l}\text { AIDS } \\
\text { BMT } \\
\text { CID } \\
\text { SOT }\end{array}$ & 24,67 \\
\hline Neurological & $\begin{array}{l}\text { Calcifications } \\
\text { Guillain-Barré } \\
\text { Hydrocephalus } \\
\text { Meningo-Encephalitis } \\
\text { Mental retardation } \\
\text { Microcephalus }\end{array}$ & $\begin{array}{l}\text { AIDS } \\
\text { CID } \\
\text { Healthy subjects }\end{array}$ & $\begin{array}{l}24,35,58,61, \\
67\end{array}$ \\
\hline Cardiological & Myocarditis (rare) & $\begin{array}{l}\text { CID } \\
\text { Healthy subjects } \\
\text { SOT }\end{array}$ & $35,58,67$ \\
\hline Endocrine system & $\begin{array}{l}\text { Adrenal, } \\
\text { Pituitary, } \\
\text { Parathyroid and } \\
\text { Thyroid glands } \\
\end{array}$ & $\begin{array}{l}\text { CID } \\
\text { Disseminated CMV }\end{array}$ & 67 \\
\hline Skin & $\begin{array}{l}\text { Petechiae } \\
\text { Purpurae } \\
\text { Rash (rare) } \\
\text { Vasculitis } \\
\end{array}$ & $\begin{array}{l}\text { AIDS } \\
\text { CID }\end{array}$ & $24,35,67$ \\
\hline Bone marrow & $\begin{array}{l}\text { Haemolytic anaemia } \\
\text { Leukopenie } \\
\text { Thrombocytopenie }\end{array}$ & $\begin{array}{l}\text { BMT } \\
\text { CID } \\
\text { Healthy subjects } \\
\text { SOT }\end{array}$ & $24,58,67$ \\
\hline Placenta & $\begin{array}{l}\text { Inflammation } \\
\text { Villitis }\end{array}$ & CID & 67 \\
\hline Immune system & $\begin{array}{l}\text { Immunosuppression } \\
\text { Superinfections }\end{array}$ & $\begin{array}{l}\text { AIDS } \\
\text { BMT } \\
\text { SOT }\end{array}$ & $\begin{array}{lll}24, & 58, & 67, \\
180 & & \end{array}$ \\
\hline Various & $\begin{array}{l}\text { Allograft rejection } \\
\text { Atherosclerosis } \\
\text { Chromosome damage } \\
\text { Graft-versus-host }\end{array}$ & $\begin{array}{l}\text { BMT } \\
\text { SOT }\end{array}$ & $\begin{array}{lrr}24, & 58, & 67 \\
130, & 180\end{array}$ \\
\hline
\end{tabular}




\subsection{Common CMV diagnostic procedures}

As for all viruses infections, there are two potential strategies for providing a diagnosis of CMV infection: the detection of virus or its components (antigens or genome) or the demonstration of a specific immune response (antibody response). A wide variety of approaches can be used to identify emerging CMV biologic activity (i.e. viral gene expression, replication and dissemination) and to discriminate between subclinical and symptomatic infection (i.e. relevant viral activity), since only the latter would require intervention.

\subsubsection{CMV detection by conventional cell culture and/or DEAFF}

Active CMV replication results in shedding of the virus into various bodily secretions such as e.g. blood, urine, liquor and saliva. The presence of infectious virus in these secretions can be demonstrated by inoculation of samples on cells that are highly permissive for CMV replication, i.e. human embryonic fibroblasts. In the conventional cell culture, these cultures are screened frequently (up to six weeks) for the appearance of the typical cytopathogenic effect (CPE) caused by active replication of the virus. Results of viral culture can also be obtained by an immunohistochemical staining procedure that is performed after one or two days of culture [46]. This technique is called: detection of early antigen fluorescent foci (DEAFF) or shell vial culture. The monoclonal antibodies used in this procedure are directed against the IE- 1 protein of the virus. The presence of infectious virus in blood of immunocompromised individuals, as detected by the viral culture procedures, is a significant risk for the onset of symptomatic infection, especially in bone marrow transplant recipients $[94,99]$. The characteristics of both CMV culture assays are summerized in table 4 .

Table 4: Characteristics of the conventional cell culture, DEAFF and pp65-antigenemia

\begin{tabular}{|l|l|l|l|}
\hline & $\begin{array}{l}\text { Conventional cell } \\
\text { culture }\end{array}$ & DEAFF & Antigenemia \\
\hline Turnaround time & 2 - 6 weeks & 18 - 48 hours & 5 hours - overnight \\
\hline Sample processing & $\begin{array}{l}\text { Recovery of PMN } \\
\text { within a few hours }\end{array}$ & $\begin{array}{l}\text { Recovery of PMN within } \\
\text { a few hours }\end{array}$ & $\begin{array}{l}\text { Recovery of PMN } \\
\text { within 4-6 hours }\end{array}$ \\
\hline Reproducibility & Low & Unknown & Few data, relatively low \\
\hline $\begin{array}{l}\text { Equipment and } \\
\text { facilities needed }\end{array}$ & $\begin{array}{l}\text { Cell-culture facility, } \\
\text { light microscopy }\end{array}$ & $\begin{array}{l}\text { Cell-culture facility, } \\
\text { IF microscopy }\end{array}$ & $\begin{array}{l}\text { Cytospin; IF or light } \\
\text { microscopy }\end{array}$ \\
\hline Advantages & $\begin{array}{l}\text { Virus isolate available } \\
\text { for further testing }\end{array}$ & $\begin{array}{l}\text { Can be used with non- } \\
\text { blood samples; rapidity } \\
\text { of procedure }\end{array}$ & $\begin{array}{l}\text { Rapidity of procedure; } \\
\text { quantitative results }\end{array}$ \\
\hline Disadvantages & $\begin{array}{l}\text { Low sensitivity; very } \\
\text { slow CPE; risk of } \\
\text { bacterial or fungal } \\
\text { contamination; rapid } \\
\text { loss of viability in } \\
\text { (some) clinical } \\
\text { specimens }\end{array}$ & $\begin{array}{l}\text { Low sensitivity; risk of } \\
\text { cell toxicity with blood } \\
\text { samples; rapid loss of } \\
\text { viability in clinical } \\
\text { specimens; not practical } \\
\text { for large numbers of } \\
\text { samples }\end{array}$ & $\begin{array}{l}\text { Requires rapid samples } \\
\text { processing for reliable } \\
\text { quantitation; not usable } \\
\text { in leukopenic samples: } \\
\text { not practical for large } \\
\text { numbers of samples }\end{array}$ \\
\hline
\end{tabular}

$\mathrm{IF}=$ immunofluorescent $\mathrm{CPE}=$ cytopathic effect $\mathrm{PMN}=$ polymorphonuclear cells. 


\subsubsection{CMV antigenemia}

Since the CMV antigenemia assay was first described in The Netherlands in 1988 by Van der Bij et al. [160], numerous studies have confirmed its clinical relevance for the diagnosis of active CMV infection $[4,110,111,157]$.

The pp65 antigenemia assay is an immunocytochemical method. In the assay, leukocytes are directly stained with labelled monoclonal antibodies directed against a structural virus protein, pp65. The pp65 antigenemia assay consists of four steps $[75,157,160]$ :

- Isolation of leukocytes by dextran separation and preparation of slides. There should be at least 200000 leukocytes per slide and at least two slides should be read.

- Fixation of slide with formaldehyde

- Immunostaining using monoclonal antibodies directed against pp65

- Reading and quantification.

The assay can be performed in one day and generates quantitative results, usually expressed as the number of pp65-antigen positive cells per 50000 polymorphonuclear leukocytes. The characteristics of the pp65-antigenemia assay are summerized in table 4.

\subsubsection{DNA detection by PCR assays}

The purpose of a polymerase chain reaction (PCR) is to produce by exponential amplification large numbers of copies of a specified DNA sequence or gene (fig 6a), even though present in rare amounts in a mixture. This is done by a chain of consecutive cycling reactions, developed in 1985 by Karry Mullis of the Cetus Corporation in California [132]. There are three major steps in a PCR: denaturation, annealing and extension (fig 6b), which are repeated for $30-50$ cycles. This is done on an automated thermocycler, which can heat and cool the tubes with the reaction mixture in a very short time. The first step is a denaturation step at high temperature, e.g. $95^{\circ} \mathrm{C}$ at which the DNA double strand melts open to single stranded DNA. The second step is the annealing phase in which the primers, each consisted of a small single stranded DNA fragment of about 20 nucleotides, anneal specific in a complementary manner to the melted single stranded DNA, according to the complementary base pairing of the DNA. In this way, annealing, mostly done at lower temperature, e.g. $50{ }^{\circ} \mathrm{C}$, results in the forming of a little piece of double stranded DNA (template and primer). Annealing only happens in case the selected template is present in the reaction tube. The third step is the extension step in which a DNA polymerase is used to extend the annealed primers complementary to the viral DNA genome target [133]. Extension results in the forming of newly synthesized double stranded DNA-fragments or amplicons, and is mostly done at a temperature of $72{ }^{\circ} \mathrm{C}$, which is the ideal working temperature of the polymerase enzyme. Characteristic for the PCR procedure is the use of the enzyme Taq DNA polymerase, which can withstand the high temperatures, used for denaturation of DNA. Undertaken a second PCR assay using amplicons from a foregoing PCR as template, can increase the overall sensitivity of detection (nested PCR). This uses a different set of PCR primers internal to the first set, and therefore can act as a confirmation of the correct amplicon produced by the first round reaction. The correct choice of primers is an important determinant of the success of any PCR. Clearly, the nucleic acid sequence of at least a part of the viral genome needs to be known, and primers must target a well-conserved region. For CMV-PCR, different parts of the CMV genome have been chosen as targets, but there is no obvious advantage in any particular one. The product of any specific PCR reaction has a known size, which can be determined by agarose gelelectrophoresis using a DNA molecular weight ladder as reference. Specific detection of the amplified DNA fragment by hybridization with a nucleic acid probe is also possible and can be undertaken within a microtitre plate format, with a colorimetric end-point, and read in a standard spectrophotometer [48]. Many commercial PCR assays employ this system. 
A

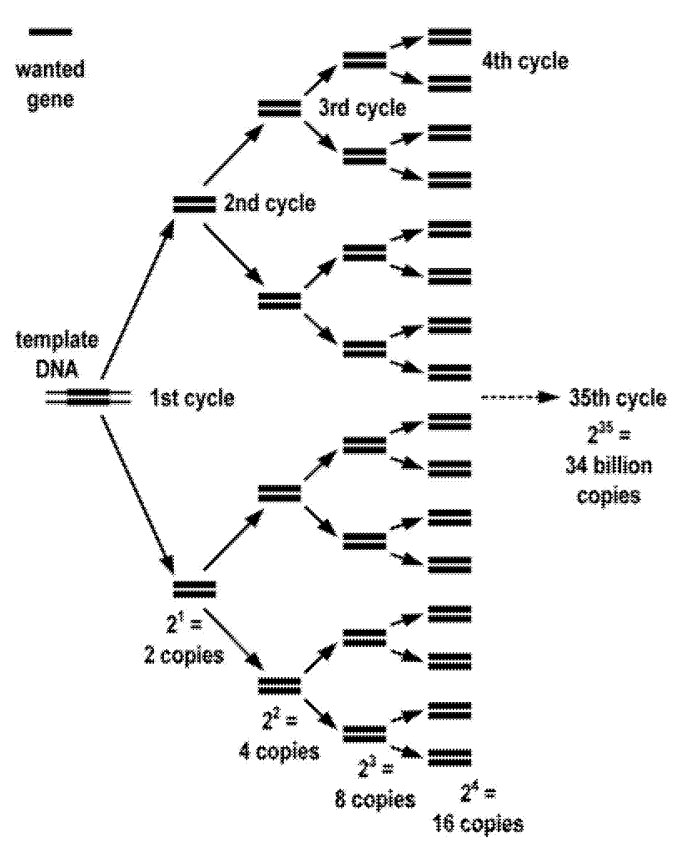

B

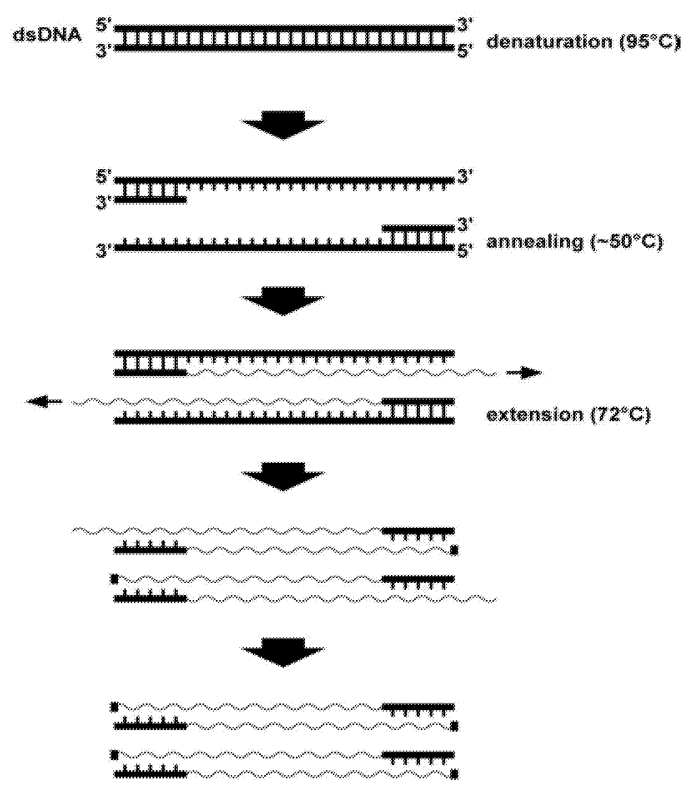

Fig 6. Exponential amplification of target DNA (fig. 6A) by repetitive cycles of denaturation, annealing and extension (fig. $6 B$ ).

\subsubsection{CMV mRNA detection by NASBA assays}

"Nucleic acid sequence-based amplification" (NASBA) [28] is a sensitive transcription-based amplification system for the specific replication of target nucleic acids in vitro followed by detection of the amplified products (amplicons). NASBA is an isothermal method of nucleic acid amplification taking place at one temperature $\left(41{ }^{\circ} \mathrm{C}\right)$ and is particularly well suited for the amplification of RNA analytes [193]. Prior to amplification, the target nucleic acid first has to be isolated. A very rapid and simple method now widely used for the isolation of nucleic acids was first described by Boom and colleagues [17]. This isolation method is based on the ability of silica to bind nucleic acid in the presence of high concentrations of the chaotropic reagent guanidine isothiocyanate. The denaturating properties of guanidine isothiocyanate form the basis for the release of nucleic acids by lysing cells or disrupting viral or bacterial particles. As this reagent also denatures DNases and RNases, degradation of the nucleic acids because of these activities is prohibited. Calibrator RNA molecules, which are identical to the target mRNA except for an internal sequence rearrangement, function as internal calibrator and are added to the sample containing the target mRNA. The target CMV mRNA, e.g. immediate early 1 or pp67, and the calibrator RNA are then amplified together through the coordinated activities of three enzymes (avian myeloblastosis virus-reverse transcriptase, RNase $\mathrm{H}$ and T7 DNA dependent RNA polymerase) and two selected primers [34]. Both amplified products are detected separately by electrochemiluminescence [161]. The original amount of the target CMV mRNA is determined from the ratio of the signal of the sample CMV mRNA divided by the signal of the internal calibrator. The application of NASBA in renal transplant recipients with CMV infection is first reported in our laboratory by Blok $[14,15]$. A graphic overview of the principle of the NASBA amplification technology is given in fig. 7. 


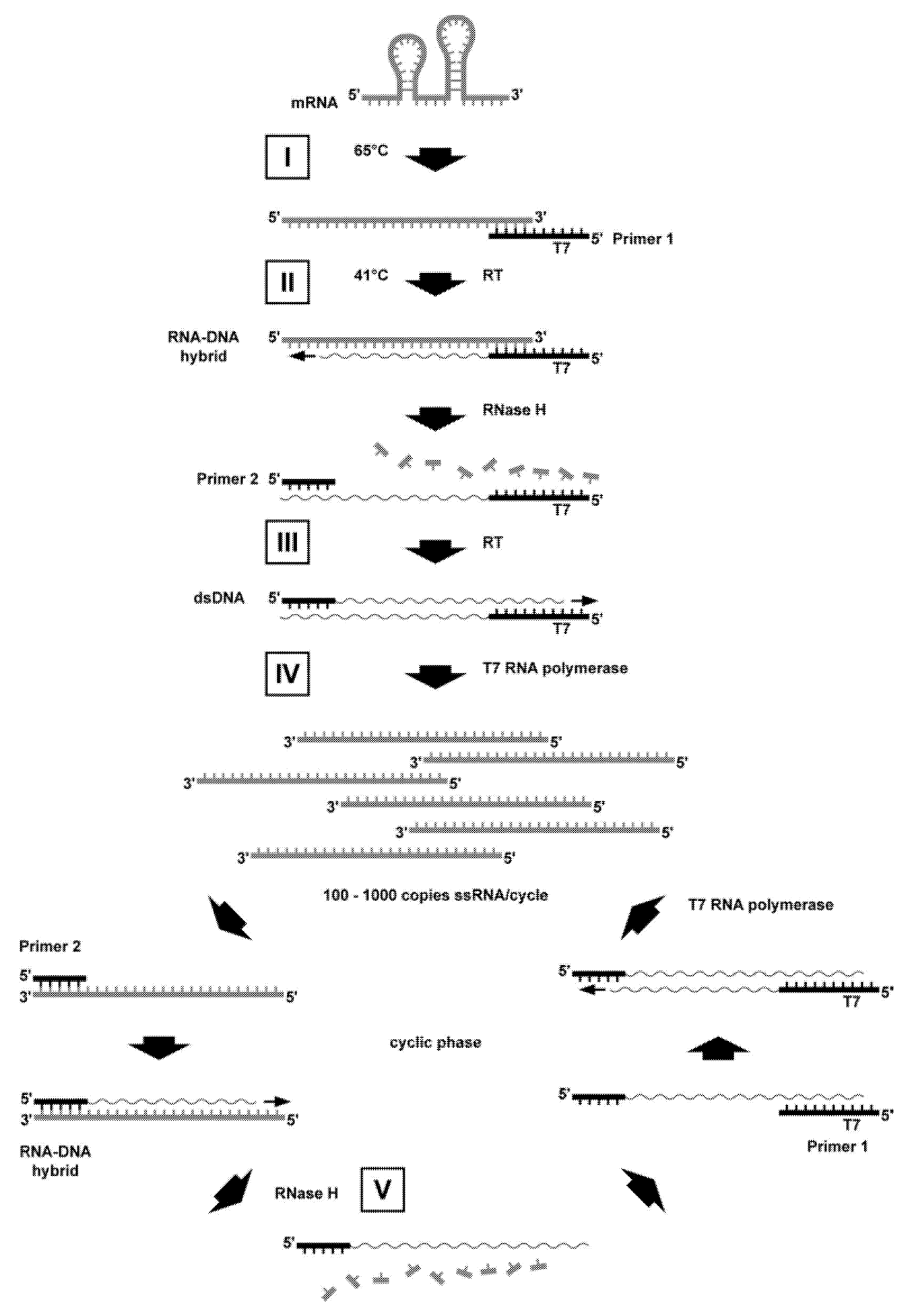

Fig 7. Isothermal amplification of RNA by NASBA: I = Denaturation of secondary structures in the single stranded (ss) mRNA molecule. II = Annealing of primer 1, containing a T7 RNA polymerase promoter region (T7), followed by elongation by the avian myeloblastosis virus reverse transcriptase (RT), and degradation of the RNA in the DNA-RNA hybrid by RNase H. III = Annealing of primer 2, followed by elongation by the RT-enzyme. This results in the formation of double stranded (ds) DNA. $I V=$ Synthesis of $100-1000$ ssRNA molecules by the dsDNA-dependent T7 RNA polymerase. $V=$ Repetition of the previous steps for about 1.5 hours. This yields about $10^{12}$ molecules of sSRNA. 


\subsubsection{Immunological response to CMV infection}

Infection of an individual with CMV is followed by humoral and cellular immune responses. Following primary infection with CMV, production of immunoglobulin (Ig) G (IgG) and IgM antibodies and cell mediated responses such as cytotoxic $\mathrm{T}$ cell responses, activation of natural killer (NK) cells and antibody-dependent killer cells occur [128]. Virions and CMV infected cells are attacked by macrophages, polymorphonuclear granulocytes, monocytes and natural killer cells. These non-specific cellular immune responses are of crucial importance in primary infections. Cellular immunity to CMV is also mediated by both cytotoxic T (CD8) lymphocytes and T helper (CD4) lymphocytes. CD8 $\mathrm{T}$ cells have cytolytic activity on infected cells and recognize viral antigens presented by MHC class I molecules. CD4 $\mathrm{T}$ cells have regulatory functions and recognize viral antigens presented by MHC class II molecules.

The cellular immunity is supported by the humoral immune responses. After primary CMV infection, CMV-specific IgM, IgG and IgA antibodies can be detected [10]. Antibody response to CMV is thought to play a role in the elimination of free circulating virus particles. Antibodies mediate antibody-dependent cellular cytotoxicity and complement activation, and can enhance phagocytosis of infected cells. Beneficial effects of hyperimmune anti-CMV globulin for preventing active infections and for the treatment of CMV pneumonitis have been described [30].

Several different formats have been used to detect CMV specific antibodies in blood of CMV infected subjects. These have included immune hemagglutination, latex agglutination, immunofluorescence, virus neutralization, radioimmunoassay, and enzymimmunoassays [151]. In the past, antigenic substrate for these assays consists mostly of lysates of virus-infected cells. More recently, several reports have demonstrated the suitability of recombinant antigens as well as peptide fragments of CMV proteins in diagnostic assays of CMV-specific IgG antibodies [83, 85, 86, 163].

For most viral infections, especially the detection of specific $\operatorname{IgM}$ antibodies has been somewhat problematic [136]. However, important progress has been achieved for detection of human CMV specific IgM antibodies. Since 1982, radioimmunoassays have been shown to have sufficient sensitivity and specificity for the detection of CMV-specific IgM antibodies in all populations studied thus far $[22,53,54,55,116]$. Current CMV-specific IgM utilizes an enzymimmunoassay format in most commercially available assays. Estimated sensitivity varies in different populations, but, overall, the sensitivity of the assays range between $50 \%$ and $90 \%$ in immunocompetent adults with acute CMV infection [90, 150]. Since 1992, antigenic materials composed of peptides or purified recombinant proteins produced through molecular biology offer an attractive alternative for the detection of CMVspecific IgM $[72,81,88,90,112,122,123,164,165]$.

\subsection{Aims of the thesis}

Human cytomegalovirus causes a lifelong persistent infection that is usually well controlled by the host immune system. However, in patients with defective immunity, CMV remains a major clinical problem. Therefore, especially in immunocompromised patients as organ transplant recipients and HIV infected patients, early identification and monitoring of CMV activity is recommended. Monitoring for CMV infection is usually performed by screening blood samples for the presence of infectious virus, viral constituents and/or specific CMV IgM and IgG antibodies.

Several years ago, detection of viral DNA, e.g. by polymerase chain reaction assays, has been introduced for identification of CMV infection in clinical practice. However, since CMV may persist for life in circulating and other cells, detection of viral DNA or DNA fragments in blood may be of 
limited diagnostic value. More recently, quantification of CMV-DNA in serial blood samples seems to be clinically more relevant $[16,18]$.

However, even with high viral loads in the systemic circulation, local immune responses in target tissues may be able to prevent virus load reaching the critical levels required to cause disease [58]. Rather than detecting CMV-DNA or antigen in the circulation, RNA expression is considered to directly reflect CMV biologic activity in vivo [101]. In this way, there is a complex and dynamic balance between CMV gene expression and host immune defences [51].

The aim of this thesis is to study the dynamic interaction between CMV and the human host immune defences. Besides other diagnostic parameters, especially the significance and clinical relevance of CMV mRNA expression and anti-CMV humoral immune responses will be evaluated in renal transplant recipients, liver transplant recipients and in HIV-1 infected patients treated with highly active anti-retroviral therapy (HAART). The outline of the study is as follows:

Chapter 1 consists of a general introduction into the world of human cytomegalovirus, including a historical perspective, the biology and structure of CMV, the replication and molecular biology of $\mathrm{CMV}$, the clinical manifestation of CMV infection and common CMV diagnostic procedures.

In chapter 2 we compare the value of different diagnostic tests for early detection of CMV infection in renal transplant recipients. For this purpose the following tests were used: DNA detection by PCR, detection of immediate early 1 mRNA and pp67 mRNA by NASBA, detection of pp65 protein by antigenemia testing, and detection of CMV by culturing the virus on fibroblasts.

In chapter 3 we focus on the diagnostic value of NASBA for the detection of CMV infection, not only in renal transplant recipients, but also in liver transplant recipients and compare these data with results obtained by other tests, among them antigenemia and antibody response.

In chapter 4 we study differences in the profiles of CMV RNA transcripts and anti-CMV IgM antibodies in renal transplant recipients with productive CMV infection, and in renal transplant recipients with a non-productive CMV infection.

In chapter 5 we compare, not only the onset, but also the duration of IE1 mRNA expression in blood (cells) in different subgroups of renal transplant recipients. We investigate whether or not the IE1 mRNA expression is correlated with differences in patient characteristics and/or differences in use of immune suppressiva. In addition, and for the first time as far as we know, attention has been given to the expression of IE1 mRNA in different CMV gB genotypes.

In chapter 6 we study whether seropositivity for CMV and other herpesviruses (HSV-1 and HSV-2) influences the CD4 cell response after successful initiation of highly active antiretroviral therapy in HIV-1 infected patients. Therefore, in an observational clinical cohort of $128 \mathrm{HIV}-1$ seropositive patients, participating in the national ATHENA project, the CD4 cell count and HIV-1 viral loads were measured at least every 3 months. The CD4 cell response was analysed in CMV seropositive and in CMV seronegative patients for as long as the HIV-1 viral load remained continuously undetectable.

Chapter 7 consists of a general discussion and conclusions of this thesis. 


\section{References}

1. Ahlfors K, Ivarsson SA, Harris S. Report on a long-term study of maternal and congenital cytomegalovirus infection in Sweden. Review of prospective studies available in literature. Scand J Infect Dis 1999;31:443-457.

2. Andersen HK. Serologic differentiation of human cytomegalovirus strains using rabbit hyperimmune sera. Brief report. Arch Gesamte Virusforsch 1971;33:187-191.

3. Andersen HK, Brostrom K, Hansen KB, Leerhoy J, Pedersen M, Osterballe O, Felsager U, Mogensen S. A prospective study on the incidence and significance of congenital cytomegalovirus infection. Acta Paediatr Scand 1979;68:329-336.

4. Baldanti F, Revello MG, Percivalle E, Gerna G. Use of the human cytomegalovirus (HCMV) antigenemia assay for diagnosis and monitoring of HCMV infections and detection of antiviral drug resistance in the immunocompromised. J Clin Virol 1998;11:51-60.

5. Balk AH, Weimar W. Chronic heart graft rejection in the clinical setting. In: Organ Transplantation: Long-term Results (Paul LC, Solez K, ed) New York: Marcel Dekker, 1992;pp187-195.

6. Bando K, Paradis IL, Komatsu K, Konishi H, Matsushima M, Keena RJ, Hardesty RL, Armitage JM, Griffith BP. Analysis of time-dependent risks for infection, rejection, and death after pulmonary transplantation. J Thorac Cardiovasc Surg 1995;109:49-57; discussion 57-59.

7. Barbi M, Binda S, Primache V, Clerici D. Congenital cytomegalovirus infection in a northern Italian region. NEOCMV Group. Eur J Epidemiol 1998;14:791-796.

8. Benfield MR, McDonald R, Sullivan EK, Stablein DM, Tejani A. The 1997 Annual Renal Transplantation in Children Report of the North American Pediatric Renal Transplant Cooperative Study (NAPRTCS). Pediatr Transplant 1999;3:152167.

9. Berry GJ, Rizeq MN, Weiss LM, Billingham ME. Graft coronary disease in pediatric heart and combined heart-lung transplant recipients: a study of fifteen cases. J Heart Lung Transplant 1993;12:S309-S319.

10. Betts RF, Schmidt SG. Cytolytic IgM antibody to cytomegalovirus in primary cytomegalovirus infection in humans. J Infect Dis 1981;143:821-826.

11. Billingham ME. Pathology of graft vascular disease after heart and heart-lung transplantation and its relationship to obliterative bronchiolitis. Transplant Proc 1995;27:2013-2016.

12. Blakolmer K, Seaberg EC, Batts K, Ferrell L, Markin R, Wiesner R, Detre K, Demetris A. Analysis of the reversibility of chronic liver allograft rejection implications for a staging schema [published erratum in Am J Surg Pathol 2000;24:164]. Am J Surg Pathol 1999;23:1328-1339.

13. Blakolmer K, Jain A, Ruppert K, Gray E, Duquesnoy R, Murase N, Starzl TE, Fung JJ, Demetris AJ. Chronic liver allograft rejection in a population treated primarily with tacrolimus as baseline immunosuppression: long-term follow-up and evaluation of features for histopathological staging. Transplantation 2000;69:2330-2336.

14. Blok MJ, Goossens VJ, van Herle SJ, Top B, Tacken N, Middeldorp JM, Christiaans MH, van Hooff JP, Bruggeman CA. Diagnostic value of monitoring human cytomegalovirus late pp67 mRNA expression in renal allograft recipients by nucleic acid sequence-based amplification. J Clin Microbiol 1998;36:1341-1346.

15. Blok MJ, Christiaans MH, Goossens VJ, van Hooff JP, Top B, Middeldorp JM, Bruggeman CA. Evaluation of a new method for early detection of active cytomegalovirus infections. A study in kidney transplant recipients. Transpl Int 1998;11(suppl 1):S107-S109.

16. Boeck M, Boivin G. Quantitation of cytomegalovirus: Methodologic aspects and clinical application. Clin Microbiol Rev 1998; 11:533-554.

17. Boom R, Sol CJA, Salimans MMM, Hansen CL, Wertheim-van Dillen PME, Noordaa van der J. Rapid and simple method for the purification of nucleic acids. J Clin Microbiol 1990;28:495-503.

18. Boom R, Sol C, Weel J, Gerrits Y, De Boer M, Werthein-Van Dillen P. A highly sensitive assay for the detection and quantification of human cytomegalovirus DNA in serum and plasma by PCR and electrochemiluminescence. J Clin Microbiol 1999; 37:1489-1497. 
19. Bouedjoro-Camus MC, Novella JL, Toupance O, Wynckel A, Carquin J, Jolly D, Chanard J. Cytomegalovirus infection, a risk factor for acute graft rejection in renal transplant recipients. A case-controlled study. Presse Med 1999;28:619-624.

20. Bowen EF, Wilson P, Cope A, Sabin C, Griffiths P, Davey C, Johnson M, Emery V. Cytomegalovirus retinitis in AIDS patients: influence of cytomegaloviral load on response to ganciclovir, time to recurrence and survival. AIDS 1996;10:15151520 .

21. Britt WJ and Auger D. Human cytomegalovirus virion-associated protein with kinase activity. J Virol 1986; 59:185-188.

22. Britt WJ, Vugler L: Antiviral antibody responses in mothers and their newborn infants with clinical and subclinical congenital cytomegalovirus infections. J Infect Dis 1989; 161:214-219.

23. Britt WJ, Vugler L, Butfiloski EJ, Stephens EB. Cell surface expression of human cytomegalovirus (HCMV) gp55-116 $(\mathrm{gB})$ : use of HCMV-recombinant vaccina virus-infected cells in analysis of the human neutralizing antibody response. J Virol 1990;64:1079-1085.

24. Britt WJ, Alford CA. Cytomegalovirus. In: Fields BN, Knipe DM, Chanock RM, et al, eds. Fields Virology. $3^{\text {rd }}$ ed. Vol.2 New York: Raven Press 1996; 3:2493-2523.

25. Cecka M. Clinical outcome of renal transplantation. Factors influencing patient and graft survival. Surg Clin North Am 1998;78:133-148.

26. Cha TA, Tom E, Kemble GW, Duke GM, Mocarski ES, Spaete RR. Human cytomegalovirus clinical isolates carry at least 19 genes not found in laboratory strains. J Virol 1996; 70:78-83.

27. Cole R, Kuttner AG: A filterable virus present in the submaxillary glands of guinea pigs. J Exp Med 1926;44:855-873.

28. Compton J. Nucleic acid sequence-based amplification. Nature 1991;350:91-92.

29. Compton T, Nepomuceno RR, Nowlin DM. Human cytomegalovirus penetrates host cells by pH-independent fusion at the cell surface. Virology 1992;191:387-395.

30. Condie RM, O'Reilly RJ. Prevention of cytomegalovirus infection by prophylaxis with intravenous, hyperimmune, native unmodified cytomegalovirus globulin. Am J Med 1984;26:134-141.

31. Cramer DV. Cardiac graft atherosclerosis. In: Organ Transplantation: Long-term Results (Paul LC, Solez K, ed) New York: Marcel Dekker, 1992;pp173-195.

32. Cremer NE, Cossen CK, Shell GR, Pereira L. Antibody response to cytomegalovirus polypeptides captured by monoclonal antibodies on the solid phase in enzyme immunoassays. J Clin Microbiol 1985;21:517-521.

33. Dal Monte P, Bessia C, Landini MP, Michelson S. Expression of human cytomegalovirus ppUL83 (pp65) in a stable cell line and its association with metaphase chromosomes. J Gen Virol 1996; 77:2591-2596.

34. Deiman B, van Aarle P, Sillekens P. Characteristics and applications of nucleic acid sequence-based amplification (NASBA). Molecular Biotechnology 2002;20:163-179.

35. Demmler GJ: Acquired cytomegalovirus infections. Textbook of Pediatric Infectious Disease. Feigin RD, Cherry JD (eds). Philadelphia, WB Saunders Co, 3rd Ed, Vol 2, 1992, pp 1532-1547

36. Detels R, Leach CT, Hennessey K, Liu Z, Visscher BR, Cherry JD. Persistent cytomegalovirus infection of semen increases risk of AIDS. J Infect Dis 1994;169:766-768.

37. Dummer JS, Ho M, Rabin B, Griffith BP, Hardesty RL, Bahnson HT. The effect of cytomegalovirus and Epstein-Barr virus infection on T lymphocyte subsets in cardiac transplant patients on cyclosporine. Transplantation 1984;38:433-435.

38. Einhorn L, Gadler H, Wahren B. Adsorption of purified human cytomegalovirus and induction of early antigens in different cells. J Med Virol 1982;10:225-234.

39. Everett JP, Hershberger RE, Norman DJ et al. Prolonged cytomegalovirus infection with viremia is associated with development of cardiac allograft vasculopathy. J Heart Lung Transplant 1992;11:S133-S137.

40. Fietze E, Prosch S, Reinke P, Stein J, Docke WD, Staffa G, Loning S, Devaux S, Emmrich F, von Baehr R, et al. Cytomegalovirus infection in transplant recipients. The role of tumor necrosis factor. Transplantation 1994;58:675-680. 
41. Fioretti A, Furukawa T, Santoli D, Plotkin SA. Nonproductive infection of guinea pig cells with human cytomegalovirus. J Virol 1973;11:998-1003.

42. George MJ, Snydman DR, Werner BG, Griffith J, Falagas ME, Dougherty NN, Rubin RH. The independent role of cytomegalovirus as a risk factor for invasive fungal disease in orthotopic liver transplant recipients. Boston Center for Liver Transplantation CMVIG-Study Group. Cytogam, MedImmune, Inc. Gaithersburg, Maryland. Am J Med 1997;103:106-113.

43. Gibson W. Structural and nonstructural proteins of strain Colburn cytomegalovirus. Virology 1981;111:516-537.

44. Gibson W. Protein counterparts of human and simian cytomegaloviruses. Virology 1983;128:391-406.

45. Gibson W, Marcy AI, Comolli JC, Lee J. Identification of precursor to cytomegalovirus capsid assembly protein and evidence that processing results in loss of its carboxy-terminal end. J Virol 1990;64:1241-1249.

46. Gleaves CA, Smith TF, Shuster EA, Pearson GR. Comparison of standard tube and shell vial cell culture techniques for the detection of cytomegalovirus in clinical specimens. J Clin Microbiol 1985;21:217-221.

47. Goodpasture EW, Talbot FB: Concerning the nature of protozoan-like' cells in certain lesions in infancy. Am J Dis Children 1921;21:415-425.

48. Gor D, Lee D, Emery VC. Detection of human cytomegalovirus polymerase chain reaction products using oligonucleotide probes directly conjugated to alkaline phophatase. Journal of Virological Methods 1996;61:145-150.

49. Gouarin S, Palmer P, Cointe D, Rogez S, Vabret A, Rozenberg F, Denis F, Freymuth F, Lebon P, Grangeot-Keros L. Congenital HCMV infection: a collaborative and comparative study of virus detection in amniotic fluid by culture and by PCR. Journal of Clinical Virology 2001;21:47-55.

50. Grefte JMM, van der Gun BFT, Schmolke S, van der Giessen M, van Son WJ, Plachter B, Jahn G, The TH. The lower matrix protein pp65 is the principal viral antigen present in peripheral blood leukocytes during an active cytomegalovirus infection. J Gen Virol 1992; 73:923-932.

51. Greyer AE. The dynamic balance between HCMV gene expression and host immune defenses. PhD thesis Vrije Universiteit Amsterdam 2001.

52. Griffith BP, Hardesty RL, Armitage JM, Hattler BG, Pham SM, Keenan RJ, Paradis I. A decade of lung transplantation. Ann Surg 1993;218:310-318; discussion 318-320.

53. Griffiths PD: The presumptive diagnosis of primary cytomegalovirus infection in early pregnancy by means of a radioimmunoassay for specific IgM antibodies. Br J Obstet Gynaecol 1981;88:582-587.

54. Griffiths PD, Stagno S, Pass RF, Smith RJ, Alford CA: Congenital cytomegalovirus infection: diagnostic and prognostic significance of the detection of specific IgM antibodies in cord serum. Pediatrics 1982;69:544-549.

55. Griffiths PD, Stagno S, Pass RF, Smith RJ, Alford CA: Infection with cytomegalovirus during pregnancy: specific IgM antibodies as a marker of recent primary infection. J Infect Dis 1982;145:647-653.

56. Griffiths PD, Baboonian C, Rutter D, Peckham C. Congenital and maternal cytomegalovirus infections in a London population. Br J Obstet Gynaecol 1991;98:135-140.

57. Griffiths PD. Studies of viral co-factors for human immunodeficiency virus in vitro and in vivo. J Gen Virol 1998;79:213-220.

58. Griffiths PD in Cytomegalovirus, chapter 2C in Principles and Practice of Clinical Virology, fourth edition. Edited by AJ Zuckerman, JE Banatvala and JR Pattison. 2000. John Wiley \& Sons, Ltd.

59. Hahn G, Jores R, Mocarski ES. Cytomegalovirus remains latent in a common precursor of dendritic and myeloid cells. Proc Natl Acad Sci USA 1998; 95:3937-3942.

60. Halwachs-Baumann G, Genser B, Danda M, Engele H, Rosegger H, Folsch B, Maurer U, Lackner H, Truschnig-Wilders M. Screening and diagnosis of congenital cytomegalovirus infection: a 5-y study. Scand J Infect Dis 2000;32:137-142.

61. Hanshaw JB, Dudgeon JA, Marshall WC. Viral diseases of the fetus and newborn. Philadelphia, WB Saunders Co, $2^{\text {nd }}$ Ed, 1985. 
62. Hanshaw JB: Cytomegalovirus infections. Textbook of Pediatric Infectious Diseases. Feigin RD, Cherry JD (eds). Philadelphia, WB Saunders Co, 2nd Ed, 1987

63. Haverich A. Experience with lung transplantation. Ann Thorac Surg 1999;67:305-312.

64. Heng D, Sharples LD, McNeil K, Stewart S, Wreghitt T, Wallwork J. Bronchiolitis obliterans syndrome: incidence, natural history, prognosis, and risk factors. J Heart Lung Transplant 1998;17:1255-1263.

65. Hensel G, Meyer H, Gartner S, Brand G, Kern HF. Nuclear localization of the human cytomegalovirus tegument protein pp150 (ppUL32). J Gen Virol 1995; 76:1591-1601.

66. Heublein B, Haverich A, Borst HG. Long-term follow-up after orthotopic heart transplantation. Thorac Cardiovasc Surg 1990;38:285-290.

67. Ho M. Biology and Infection; second edition (1991). Plenum Publishing Corporation; 233 Spring Street, New York, N.Y. 10013.

68. Ho M: Advances in understanding cytomegalovirus infection after transplantation. Transplant Proc 1994; 26(suppl):7-11

69. Husni RN, Gordon SM, Longworth DL, Arroliga A, Stillwell PC, Avery RK, Maurer JR, Mehta A, Kirby T. Cytomegalovirus infection is a risk factor for invasive aspergillosis in lung transplant recipients. Clin Infect Dis 1998;26:753755.

70. Irmiere A, Gibson W. Isolation and characterization of a noninfectious virion-like particle released from cells infected with human strains of cytomegalovirus. Virology 1983;130:118-133.

71. Irmiere A, Gibson W. Isolation of human cytomegalovirus intranuclear capsids, characterization of their protein constituents, and demonstration that the B-capsid assembly protein is also abundant in noninfectious enveloped particles. $\mathrm{J}$ Virol 1985;56:277-283.

72. Jahn G, Scholl BC, Traupe B, Fleckenstein B. The two major structural phosphoproteins (pp65 and pp150) of human cytomegalovirus and their antigenic properties. J Gen Virol 1987; 68:1327-1337.

73. Jahn G. High incidence of CMV reactivation in blood and lung of surgical intensive care patients. J Clin Virol 1999;12(2):102.

74. Jesionek and Kiolemenoglou. Über einen Befund von protozoën-artigen Gebilden in den Organen eines hereditärluetischen Fötus (in German). Munch Med Wsc 1904;51:1905-1907.

75. Jiwa NM, van de Rijke FM, Mulder A, van der Bij W, The TH, Rotbarth PH, Velzing J, van der Ploeg M, Raap AK: An improved immunochemical method for the detection of human cytomegalovirus antigens in peripheral blood leukocytes. Histochemistry 1989;91:345-349.

76. Kaariainen L, Klemola E, Paloheimo J: Rise of cytomegalovirus antibodies in an infectious-mononucleosis-like syndrome after transfusion. BMJ 1966; 2:1270-1272

77. Klages S, Ruger B, Jahn G. Multiplicity dependent expression of the predominant phosphoprotein pp65 of human cytomegalovirus. Virus Res 1989; 12:159-168.

78. Kondo K, Kaneshima H, Mocarski ES. Human cytomegalovirus latent infection of granulocyte-macrophage progenitors. Proc Natl Acad Sci USA 1994;91:11879-11883.

79.Kondo K, Xu J, Mocarski ES. Human cytomegalovirus latent gene expression in granulocyte-macrophage progenitors in culture and in seropositive individuals. Proc Natl Acad Sci USA 1996;93:11137-11142.

80. Kovacs A, Schluchter M, Easley K, Demmler G, Shearer W, La Russa P, Pitt J, Cooper E, Goldfarb J, Hodes D, Kattan M, McIntosh K. Cytomegalovirus infection and HIV-1 disease progression in infants born to HIV-1 infected women. Pediatric Pulmonary and Cardiovascular Complications of Vertically Transmitted HIV Infection Study Group. N Engl J Med 1999;341:77-84.

81. Kraat YJ, Stals S, Landini MP, Bruggeman CA: Cytomegalovirus IgM antibody detection: Comparison of five assays. New Microbiol 1993;16:297-307. 
82. Kramer MF, Coen DM. Quantification of transcripts from the ICP4 and thymidine kinase genes in mouse ganglia latently infected with herpes simplex virus. J Virol 1995;69:1389-1399.

83. Kropff B, Landini MP, Mach M: An ELISA using recombinant proteins for the detection of neutralizing antibodies against human cytomegalovirus. J Med Virol 1993;39:187-195.

84. Kutza AS, Muhl E, Hackstein H, Kirchner H, Bein G. High incidence of active cytomegalovirus infection among septic patients. Clin Infect Dis 1998;26,1076-1082.

85. Landini MP, Guan MX, Jahn G, Lindenmaier W, Mach M, Ripalti A, Necker A, Lazzarotto T, Plachter B. Large-scale screening of human sera with cytomegalovirus recombinant antigens. J Clin Microbiol 1990;28:1375-1379.

86. Landini MP, Ripalti A, Sra K, Pouletty P: Human cytomegalovirus structural proteins: immune reaction against pp 150 synthetic peptides. J Clin Microbiol 1991;29:1868-1872.

87. Landini MP, Percivalle E, DiMatteo A, Morini F, Gerna G. Nuclear expression of the lower matrix protein of human cytomegalovirus in peripheral blood leukocytes of immunocompromised viraemic patients. J Gen Virol 1992; 73:437-442.

88. Landini MP: Antibody responses to human cytomegalovirus proteins. Rev Med Virol 1992;2:63-72.

89. Landini MP, Spaete RR. Human cytomegalovirus structural proteins: a report of the first nomenclature workshop. In: Michelson S, Plotkin SA, eds. Multidisciplinary approaches to understanding cytomegalovirus disease. Amsterdam: Elsevier; 1993:65-74.

90. Lazzarotto T, Dalla Casa B, Campisi B, Landini MP: Enzyme-linked immunoadsorbent assay for the detection of cytomegalovirus-IgM: comparison between eight commercial kits, immunofluorescence, and immunoblotting. J Clin Lab Anal 1992;6:216-218

91. Lipschutz B. Untersuchungen uber die Aetiologie der Krankheiten d. herpes genitalis, etc. Arch Dermatol Syphilol $1921 ; 136: 428-482$.

92. Loebe M, Schuler S, Zais O, Warnecke H, Fleck E, Hetzer R. Role of cytomegalovirus infection in the development of coronary artery disease in the transplanted heart. J Heart Transplant 1990;9:707-711.

93. Maher P, O'Toole CM, Wreghitt TG, Spiegelhalter DJ, English TA. Cytomegalovirus infection in cardiac transplant recipients associated with chronic T cell subset ratio inversion with expansion of a Leu-7+ TS-C+ subset. Clin Exp Immunol $1985 ; 62: 515-524$.

94. Manez R, Kusne S, Rinaldo C, Aguado JM, St George K, Grossi P, Frye B, Fung JJ, Ehrlich GD. Time to detection of cytomegalovirus (CMV) DNA in blood leucocytes is a predictor for the development of CMV disease in CMV-seronegative recipients of allografts form CMV-seropositive donors following liver transplantation. J Infect Dis 1996;173:1072-1076.

95. Massy ZA, Guijarro C, Wiederkehr MR, Ma JZ, Kasiske BL. Chronic renal allograft rejection: immunologic and nonimmunologic risk factors. Kidney Int 1996;49:518-524.

96. Mc Gavran MH, Smith MG: Ultrastructural, cytochemical and microchemical observations on cytomegalovirus (salivary gland virus) infection of human cells in tissue culture. Exp Mol Pathol 1965;4:1-10.

97. Meyer H, Ripalti A, Landini MP, Radsak K, Kern HF, Hensel G. Human cytomegalovirus late-phase maturation is blocked by stable expressed UL32 antisense mRNA in astrocytoma cells. J Gen Virol 1996; 78:2621-2631.

98. Meyers BF, Lynch J, Trulock EP, Guthrie TJ, Cooper JD, Patterson GA. Lung transplantation: a decade of experience. Ann Surg 1999;230:362-370; discussion 370-371.

99. Meyers JD, Ljungman P, Fisher LD. Cytomegalovirus excretion as a predictor of cytomegalovirus disease after marrow transplantation: importance of cytomegalovirus viremia. J Infect Dis 1990;162:373-380.

100. Michelson S. Human cytomegalovirus escape from immune detection. Intervirology 1999;42:301-307.

101. Middeldorp JM, Sillekens P, Lunenberg J. Diagnosis of active HCMV infection: the mRNA approach. Organs and Tissues 2000; 2:99-107.

102. Mocarski ES. Cytomegalovirus biology and replication. In Roizman B, Whitley RJ, Lopez C. The human herpesviruses. New York: Raven Press 1993; 173-226. 
103. Mocarski E. Cytomegaloviruses and their replication. In: Fields BN, Knipe DM, Chanock RM, et al, eds. Fields Virology. $3^{\text {rd }}$ ed. Vol.2 New York: Raven Press 1996; 3:2447-2492.

104. Navarro D, Paz P, Tugizov S, Topp K, La Vail J, Pereira L. Glycoprotein B of human cytomegalovirus promotes virion penetration into cells, transmission of infection from cell to cell, and fusion of infected cells. Virology 1993;197:143-158.

105. New York Times June 25, 1981.

106. Nigida SM Jr, Falk LA, Wolfe LG, Deinhardt F, Lakeman A, Alford CA. Experimental infection of marmosets with a cytomegalovirus of human origin. J Infect Dis 1975;132:582-586.

107. Pavie A, Dorent R, Reagan M, Akthar R, Leger P, Vaissier E, Levasseur JP, Bors V, Gandjbakhch I. La Pitie heart transplantation: 30-year single center clinical experience. Clin Transpl 1998;:311-314.

108. Pereira L, Hoffman M, Gallo D, Cremer N. Monoclonala antibodies to human cytomegalovirus: three surface membrane proteins with unique immunological and electrophoretic properties specify cross-reactive determinants. Infect Immun 1982;36:924-932.

109. Pereira L, Hoffman M, Tatsuno M, Dondero D. Polymorphism of human cytomegalovirus glycoproteins characterized by monoclonal antibodies. Virology 1984;139:73-86.

110. Perez JL, Salva J, Niubo J. The antigenemia test for cytomegalovirus. Enferm Infecc Microbiol Clin 1994;12:251-261.

111. Perol Y, Caro V, Mazeron MC. Cytomegalovirus antigenemia assay: therapeutic usefulness and biological significance. Nouv Rev Fr Hematol 1993;35:95-98.

112. Plachter B, Wieczorek L, Scholl BC, Ziegelmaier R, Jahn G: Detection of cytomegalovirus antibodies by an enzymelinked immunosorbent assay using recombinant polypeptides of the large phosphorylated tegument protein pp150. J Clin Microbiol 1992;30:201-206.

113. Plotkin SA, Furukawa T, Zygraich N, Huygelen C. Candidate cytomegalovirus strain for human vaccination. Infect Immun 1975;12:521-527.

114. Pollard RB, Arvin AM, Gamberg P, Rand KH, Gallagher JG, Merigan TC. Specific cell-mediated immunity and infections with herpes viruses in cardiac transplant recipients. Am J Med 1982;73:679-687.

115. Quinnan GV Jr, Delery M, Rook AH, Frederick WR, Epstein JS, Manischewitz JF, Jackson L, Ramsey KM, Mittal K, Plotkin SA, et al. Comparative virulence and immunogenicity of the Towne strain and a nonattenuated strain of cytomegalovirus. Ann Intern Med 1984;101:478-483.

116. Rasmussen L, Kelsall D, Nelson R, Carney W, Hirsch M, Winston D, Preiksaitis J, Merigan TC. Virus-specific IgG and IgM antibodies in normal and immunocompromised subjects infected with cytomegalovirus. J Infect Dis 1982;145:191-199.

117. Reinke P, Fietze E, Ode-Hakim S, Prosch S, Lippert J, Ewert R, Volk HD. Late-acute renal allograft rejection and symptomless cytomegalovirus infection. Lancet 1994;344:1737-1738.

118. Remington JS, Klein JO (eds.). Infectious Diseases of the Fetus and Newborn Infant. Philadelphia: WB Saunders Co. 1995

119. Reynolds DW, Stagno S, Hosty TS, Tiller M, Alford CA. Maternal cytomegalovirus excretion and perinatal infection. N Engl J Med 1973;289:1-5.

120. Ribbert H: Über protozoenartige Zellen in der Niere eines syphilitischen Neugeborenen und in der Parotis von Kindern (in German). Zentralbl Allg Pathol u Pathol Anat 1904;15:945-948.

121. Rice GP, Schrier RD, Oldstone MB. Cytomegalovirus infects human lymphocytes and monocytes: virus expression is restricted to immediate-early gene products. Proc Natl Acad Sci USA 1984;81:6134-6138.

122. Ripalti A, Dal Monte P, Boccuni MC, Campanini F, Bergamini G, Lazzarotto T, Campisi B, Ruan Q, Landini MP: Prokaryotic expression of a large fragment of the most antigenic cytomegalovirus DNA-binding protein (ppUL44) and its reactivity with human antibodies. J Virol Methods 1994;46:39-50. 
123. Ripalti A, Ruan Q, Boccuni C, Campanini F, Bergamini G, Landini MP: Construction of polypeptide fusion antigens of human cytomegalovirus ppUL32: Reactivity with human antibodies. J Clin Microbiol 1994;32:358-363.

124. Robson L, Gibson W. Primate cytomegalovirus assembly protein: genome location and nucleotide sequence. J Virol 1989;63:669-676.

125. Roby $\mathrm{C}$ and Gibson W. Characterization of phosphoproteins and protein kinase activity of virions, noninfectious enveloped particles, and dense bodies of human cytomegalovirus. J Virol 1986; 59:714-727.

126. Roizman B. The family Herpetoviridae: general description, taxonomy and classification. In The Herpesviruses (ed. B. Roizman), pp. 1-23. Plenum Press, London, 1982.

127. Roizman B. In Fields Virology, Third edition. Chapter 71. Edited by B.N. Fields, D.M. Knipe, P.M. Howley, et al. Lippincott - Raven Publishers, Philadelphia 1996.

128. Rook AH. Interactions of cytomegalovirus with the human immune system. Rev Inf Dis 1988;10:S460-S467.

129. Rowe WP, Hartley JW,Waterman S et al.: Cytopathic agent resembling human salivary gland virus recovered from tissue cultures of human adenoids.Proc Soc Exp Biol Med 1956;92:418-424.

130. Rubin RH. The indirect effects of cytomegalovirus infection on the outcome of organ transplantation. JAMA 1989;261:3607-3609.

131. Sabin CA, Phillips AN, Lee CA, Janossy G, Emery V, Griffiths PD. The effect of CMV infection on progression of human immunodeficiency virus disease in a cohort of haemophilic men followed for up to 13 years from seroconversion. Epidemiol Infect 1995;114:361-372.

132. Saiki RK, Scharf S, Faloona F, Mullis KB, Horn GT, Erlich HA, Arnheim N. Enzymatic amplification of beta-globin genomic sequences and restriction site analysis for diagnosis of sickle cell anemia. Science 1985;230:1350-1354.

133. Saiki RK, Gelfand DH, Stoffel S, Scharf SJ, Higuchi R, Horn GT, Mullis KB, Erlich HA. Primer-directed enzymatic amplificaton of DNA with a thermostable DNA polymerase. Science 1988;239:487-491.

134. Sanchez V, Angeletti PC, Engler JA, Britt WJ. Localization of human cytomegalovirus structural proteins to the nuclear matrix of infected human fibroblasts. J Virol 1998; 72:3321-3329.

135. Schenk P, Woods AS, Gibson W. The 45-kilodalton protein of cytomegalovirus (Colburn) B-capsids is an aminoterminal extension form of the assembly protein. J Virol 1991;65:1525-1529.

136. Schmidt NJ. Rapid viral diagnosis. Med Clin North Am 1983;67:953-972.

137. Schmolke S, Kern HF, Drescher P, Jahn G, Plachter B. The dominant phosphoprotein pp65 (UL83) of human cytomegalovirus is dispensable for growth in cell culture. J Virol 1995; 69:5959-5968.

138. Schooley RT, Hirsch MS, Colvin RB, Cosimi AB, Tolkoff-Rubin NE, McCluskey RT, Burton RC, Russell PS, Herrin JT, Delmonico FL, Giorgi JV, Henle W, Rubin RH. Association of herpesvirus infections with T-lymphocyte-subset alterations, glomerulopathy, and opportunistic infections after renal transplantation. N Engl J Med 1983;308:307-313.

139. Sinclair J, Sissons P. Latent and persistent infections of monocytes and macrophages. Intervirology 1996;39:293-301.

140. Sinzger C, Jahn G. Human cytomegalovirus cell tropism and pathogenesis. Intervirology 1996;39:302-319.

141. Smith JD, de Harven E. Herpes simplex virus and human cytomegalovirus replication in WI-38 cells. II. An ultrastructural study of viral penetration. J Virol 1974;14:945-956.

142. Smith JD. Human cytomegalovirus: demonstration of permissive epithelial cells and nonpermissive fibroblastic cells in a survey of human cell lines. J Virol 1986;60:583-588.

143. Smith MG: Propagation of salivary gland virus of the mouse in tissue cultures. Proc Soc Exp Biol Med 1954;86:435-440.

144. Smith MG: Propagation in tissue cultures of a virus from human salivary gland virus disease. Proc Soc Exp BiolMed 1956;92:424-430. 
145. Snydman DR, Werner BG, Heinze-Lacey B, Berardi VP, Tilney NL, Kirkman RL, Milford EL, Cho SI, Bush HL Jr, Levey AS, et al. Use of cytomegalovirus immune globulin to prevent cytomegalovirus disease in renal-transplant recipients. N Engl J Med 1987;317:1049-1054.

146. Snydman DR, Werner BG, Dougherty NN, Griffith J, Rubin RH, Dienstag JL, Rohrer RH, Freeman R, Jenkins R, Lewis WD, et al. Cytomegalovirus immune globuline prophylaxis in liver transplantation. A randomized, double-blind, placebocontrolled trial. The Boston Center for Liver Transplantation CMVIG Study Group. Ann Intern Med 1993;119:984-991.

147. Soderberg-Naucler C, Nelson JY. Human cytomegalovirus latency and reactivation - A delicate balance tween the virus and its host's immune system. Intervirology 1999;42:314-321.

148. Stagno S, Reynolds DW, Pass RF, Alford CA. Breast milk and the risk of cytomegalovirus infection. N Engl J Med 1980;302:1073-1076.

149. Stagno S, Pass RF, Dworsky ME, Alford CA. Maternal cytomegalovirus infection and perinatal transmission. In: Knox GE, ed. Clinical obstetrics and gynecology. Philadelphia: JB Lippincott; 1982:563-576.

150. Stagno S, Tinker MK, Elrod C, Fuccillo D, Cloud G, O'Beirne AJ: Immunoglobulin M antibodies detected by enzymelinked immunosorbent assay and radioimmunoassay in the diagnosis of cytomegalovirus infections in pregnant women and newborn infants. J Clin Microbiol 1985;21:930-935.

151. Stagno S, Pass RF, Britt WJ: Cytomegalovirus. In: Schmidt NJ, Emmons RW, eds. Diagnostic procedures for viral, ricketsial and chlamydial infections. 6th ed. Washington, DC: American Public Health Association; 1989:321-378.

152. Sterner G, Agell BO, Wahren B, Espmark A. Acquired cytomegalovirus infection in older children and adults. Scand J Infect Dis 1970;2:95-103.

153. Stinski MF, Mocarski ES, Thomsen DR, Urbanowski ML. DNA of human cytomegalovirus: size heterogeneity and defectiveness resulting from serial undiluted passage. J Virol 1979; 31:231-239.

154 Sundaresan S. Bronchiolitis obliterans. Semin Thorac Cardiovasc Surg 1998;10:221-226.

155. Sweet C. The pathogenicity of cytomegalovirus. FEMS Microbiology reviews 1999;23:457-482.

156. Taylor-Wiedeman J, Sissons P, Sinclair J. Induction of endogenous human cytomegalovirus gene expression after differentiation of monocytes from healthy carriers. J Virol 1994;68:1597-1604.

157. The TH, van den Berg AP, Harmsen MC, van der Bij W, van Son W. The cytomegalovirus antigenemia assay: a plea for standardization. Scand J Infect Dis Suppl 1995;99:25-29.

158. Tietze A: Ein Protozoenbefund in einer erkrankten Parotitis (in German). Mitteilungen aus den Grenzgebieten der Medizin und Chirurgie.1905;14:303-310.

159. Tollemar J, Ringden O, Bostrom L, Nilsson B, Sundberg B. Variables predicting deep fungal infections in bone marrow transplant recipients. Bone Marrow Transplant 1989;4:635-641.

160. Van der Bij W, Torensma R, van Son WJ, Anema J, Schirm J, Tegzess AM, The TH. Rapid immunodiagnosis of active cytomegalovirus infection by monoclonal antibody staining of blood leucocytes. J Med Virol 1988; 25:179-188.

161. Van Gemen B, Van Beuningen R, Nabbe A, van Strijp D, Jurriaans S, Lens P, Kievits T. A one-tube quantitative HIV-1 RNA NASBA nucleic acid amplification assay using electrochemiluminescent (ECL) labelled probes. J Virol Methods 1994;49:157-168.

162. Von Glahn WC, Pappenheimer AM: Intranuclear inclusions in visceral disease. Am J Pathol 1925;1:445-465.

163. Vornhagen R, Baur A, Jahn G, Hinderer W, Nebel-Schickel H, Horn J, Wolf H, Sonneborn HH. Recombinant antigens in viral diagnostics. Bietr Infusionsther Tranfusionsmed 1992;30:78-81.

164. Vornhagen R, Plachter B, Hinderer W, The TH, Van Zanten J, Matter L, Schmidt CA, Sonneborn HH, Jahn G: Early serodiagnosis of acute human cytomegalovirus infection by enzyme-linked immunosorbent assay using recombinant antigens. J Clin Microbiol 1994; 32:981-986. 
165. Vornhagen R, Hinderer W, Sonneborn HH, Bein G, Matter L, The TH, Jahn G, Plachter B: The DNA-binding protein pUL57 of human cytomegalovirus is a major target antigen for the immunoglobulin $\mathrm{M}$ antibody response during acute infection. J Clin Microbiol 1995;33:1927-1930.

166. Wagner JA, Ross H, Hunt S, Gamberg P, Valantine H, Merigan TC, Stinson EB. Prophylactic ganciclovir treatment reduces fungal as well as cytomegalovirus infections after heart transplantation. Transplantation 1995;60:1473-1477.

167. Wahlers T, Haverich A, Schafers HJ, Hirt SW, Fieguth HG, Jurmann M, Zink C, Borst HG. Chronic rejection following lung transplantation. Incidence, time pattern and consequences. Eur J Cardiothorac Surg 1993;7:319-323.

168. Weiner RS, Bortin MM, Gale RP, Gluckman E, Kay HE, Kolb HJ, Hartz AJ, Rimm AA. Interstitial pneumonitis after bone marrow transplantation. Assessment of risk factors. Ann Intern Med 1986; 104:168-175

169. Welch AR, McNally LM, Gibson W. Cytomegalovirus assembly protein nested gene family: four 3'-coterminal transcripts encode four in-frame, overlapping proteins. J Virol 1991;65:4091-4100.

170. Weller TH, Macauley JC,Craig JM, Wirth P: Isolation of intranuclear inclusion producing agents from infants with illnesses resembling cytomegalic inclusion disease. Proc Soc Exp Biol Med 1957;94:4-12.

171. Weller TH, Hanshaw JB, Scott DE: Serologic differentiation of viruses responsible for cytomegalic inclusion disease. Virology 1960;12:130-132.

172. Weller TH. Cytomegaloviruses: the difficult years. J Infect Dis 1970;122:532-539.

173. Wiesner RH, Batts KP, Krom RA. Evolving concepts in the diagnosis, pathogenesis, and treatment of chronic hepatic allograft rejection. Liver Transpl Surg 1995;5:388-400.

174. Wright HT Jr, Goodheart CR, Lielausis A: Human cytomegalovirus. Morphology by negative staining. Virology 1964;23:419-424.

175. Boyle KA, Compton. Receptor-binding properties of a soluble form of human cytomegalovirus glycoprotein B. J Virol $1998 ; 72: 1826-1833$

176. Chee MS, Bankier AT, Beck S et al. Analysis of the protein coding content of the sequence of human cytomegalovirus strain AD169. Curr Top Microbiol Immunol 1990;154:125-169.

177. Compton T, Nowlin DM, Cooper NR. Initiation of human cytomegalovirus infection requires initial interaction with cell surface heparan sulfate. Virology 1993;193:834-841.

178. Davison AJ, Akter P, Cunningham C, Dolan A, Addison C, Dargan DJ, Hassan-Walker AF, Emery VC, Griffiths PD, Wilkinson GWG. Homology between the human cytomegalovirus RL11 gene family and human adenovirus E3 genes. J Gen Virol 2003;84:657-663.

179. Hobom U, Brune W, Messerle M, Hahn G, Koszinowski UH. Fast screening procedures for random transposon libraries of cloned herpesvirus genomes: mutational analysis of human cytomegalovirus envelope glycoprotein genes. J Virol 2000;74:7720-7729.

180. Sinzger C, Schmidt K, Knapp J, Kahl M, Beck R, Waldman J, Hebart H, Einsele H, Jahn G. Modification of human cytomegalovirus tropism through propagation in vitro is associated with changes in the viral genome. J Gen Virol $1999 ; 80: 2867-2877$.

181. Waldman WJ, Sneddon JM, Stephens RE, Roberts WH. Enhanced endothelial cytopathogenicity induced by a cytomegalovirus strain propagated in endothelial cells. J Med Virol $1989 ; 28$ :223-230.

182. Benko DM, Haltiwanger RS, Hart GW, Gibson W. Virion basic phosphoprotein form human cytomegalovirus contains O-linked N-acetyl-glucosamine. Proc Natl Acad Sci USA 1988;85:2573-2577.

183. Biegalke BJ, Geballe AP. Sequence requirements for activation of the HIV-1 LTR by human cytomegalovirus. Virology 1991;183:381-385.

184. Chou SW, Dennison KM. Analysis of interstrain variation in cytomegalovirus glycoprotein B sequences encoding neutralization-related epitopes. J Infect Dis 1991;163:1229-1234. 
185. Mocarski ES, Abenes GB, Manning WC, et al. Molecular genetic analysis of cytomegalovirus gene regulation in growth, persistence and latency. Curr Top Microbiol Immunol 1990;154:47-74.

186. Mocarski ES, Kemble GW, Lyle JM, Greaves RF. A deletion mutant in the human cytomegalovirus gene encoding IE1(491aa) is replication defective due to a failure in autoregulation. Proc Natl Acad Sci USA 1996;93:11321-11326.

187. Spector DH. Activation and regulation of human cytomegalovirus early genes. Intervirology 1996;39:361-377.

188. Stamminger T, Puchtler E, Fleckenstein B. Discordant expression of the immediate-early 1 and 2 gene regions of human cytomegalovirus at early times after infection involves posttranscriptional processing events. J Virol 1991;65:2273-2282.

189. Stenberg RM. The human cytomegalovirus major immediate-early gene. Intervirology 1996;39:343-349.

190. Stenberg RM, Depto AS, Fortney J, Nelson JA. Regulated expression of early and late RNAs and proteins from the human cytomegalovirus immediate-early gene region. J Virol 1989;63:2699-2708.

191. Walker S, Hagemeier C, Sissons JG, Sinclair JH. A 10-base-pair element of the human immunodeficiency virus type 1 long terminal repeat (LTR) is an absolute requirement for transactivation by the human cytomegalovirus 72-kilodalton IE1 protein but can be compensated for by other LTR regions in transactivation by the 80-kilodalton IE2 protein. J Virol 1992;66:1543-1550.

192. Davis MG, Huang ES. Nucleotide sequence of a human cytomegalovirus DNA fragment encoding a 67-kilodalton phosphorylated viral protein. J Virol 1985;56:7-11.

193. Romano JW, Williams KG, Shurtliff RN, Ginocchio C, Kaplan M. NASBA technology: isothermal RNA amplification in qualitative and quantitative diagnostics. Immunol Invest 1997;26:15-28. 
Chapter 2

\title{
EARLY DETECTION OF CYTOMEGALOVIRUS IN RENAL TRANSPLANT RECIPIENTS: COMPARISON OF PCR, NASBA, PP65 ANTIGENEMIA, AND VIRAL CULTURE
}

\author{
Valère J. Goossens ${ }^{1}$, Marinus J. Blok ${ }^{1}$, Maarten H.L. Christiaans ${ }^{2}$, Peter Sillekens ${ }^{3}$, \\ Jaap M. Middeldorp ${ }^{3}$, Cathrien A. Bruggeman ${ }^{1}$ \\ ${ }^{1}$ Department of Medical Microbiology, University Hospital Maastricht \\ ${ }^{2}$ Department of Internal Medicine, University Hospital Maastricht \\ ${ }^{3}$ NASBA Development Unit, Organon Teknika, Boxtel, The Netherlands
}

Transplantation Proceedings 2000; 32: 155-158 



\title{
Early Detection of Cytomegalovirus in Renal Transplant Recipients: Comparison of PCR, NASBA, pp65 Antigenemia, and Viral Culture
}

\author{
V.J. Goossens, M.J. Blok, M.H.L. Christiaans, P. Sillekens, J.M. Middeldorp, and C.A. Bruggeman
}

\begin{abstract}
TFECTION with human cytomegalovirus (CMV) is common and usually subclinical. However, serious CMV infection is possible in immunocompromised individuals (eg, transplant recipients, HIV-infected patients, and pregnant women). After kidney or other solid organ transplantation, more frequent organ rejection and a higher mortality rate are seen in CMV-positive patients than in CMV-negative patients. The higher mortality rate as well as organ rejection can both be prevented in part by early antiviral treatment. However, early treatment requires early diagnosis. The purpose of this study was to select tests that allow for detection of CMV as early as possible after transplantation. We therefore compared the value of DNA detection by polymerase chain reaction (PCR), detection of immediate early 1 (IE1) mRNA and pp67 mRNA by nucleic acid sequence-based amplification (NASBA), detection of pp65 protein by antigenemia testing, and detection of CMV by culturing.
\end{abstract}

\section{DESIGN OF THE STUDY}

Thirty consecutive patients who received a kidney transplant during the period between July and November 1997, were investigated prospectively during the first 2 months postoperatively. Follow-up and sampling were done twice a week during the hospitalization period (generally at 3 to 5 weeks) after transplantation. After this period, specimens were collected at least monthly. A total of 304 specimens were screened prospectively for the presence of CMV by cell culture, pp65-antigenemia, IE1 mRNA, and pp67 mRNA. PCR was done retrospectively.

\section{MATERIALS AND METHODS PCR}

PCR amplification and detection of CMV DNA was done with a commercially available quantitative PCR detection kit (BioSource, Etten-Leur, The Netherlands), following the instructions of the manufacturer. Extraction was done after adding 20,000 copies of the internal calibration standard (ICS) to each sample. The purified nucleic acids were resuspended in $200 \mu \mathrm{L}$ of sterile water. PCR was done with $5 \mu \mathrm{L}$ of the $200 \mu \mathrm{L}$ of extracted DNA, which contained 500 copies of the ICS. After an initial denaturation step at $95^{\circ} \mathrm{C}$ for 2.5 minutes, the following temperature profile was used for 32 cycles: denaturing during 25 seconds at $94^{\circ} \mathrm{C}$; annealing during 25 seconds at $60^{\circ} \mathrm{C}$; and extension during 1 minute at $72^{\circ} \mathrm{C}$. Due to our special interest in detection of CMV as early as possible, we used this PCR only qualitatively, with a dilution of 1:20 for the denaturated PCR mix and a dilution of 1:80 for the 500 ICS copies.

\section{NASBA for pp67 mRNA and IE1 mRNA}

Isolation, amplification, and detection of pp67 mRNA, expressed from the UL65 open reading frame of human CMV, was done following the instructions of the manufacturer (NucliSens CMV pp67 Organon Teknika, Boxtel, The Netherlands). The use of the pp67 NASBA system for control RNA has been described elsewhere. ${ }^{1}$ Isolation, amplification, and detection of IE1 mRNA transcripts was done as described for pp67 mRNA. Only the differences are mentioned here. For amplification, two primers directed to exon 4 of the major immediate early gene were used. Also, a specific IE1 NASBA system for control RNA and corresponding probes were used. $^{2}$ Interpretation of the emitted signals of wild type (WT) and system control (SC) copies compared to cutoff was similar for pp67 and IE1. However, results were only accepted as valid if the sum of the WT signal and the SC signal was at least 10,000.

\section{pp65-Antigenemia Assay}

The pp65 antigen (ppUL83) was detected immunocytochemically. Leukocytes $\left(2 \times 10^{5}\right)$ were isolated from whole EDTA blood using dextran and centrifuged onto a glass slide within 4 hours after collection. The cells were subsequently fixed for 10 minutes in $0.37 \%$ formaldehyde and incubated with anti-pp65 mouse monoclonal antibodies, as described previously. ${ }^{1}$ After incubation with horseradish peroxidase-coupled rabbit antimouse IgG (Dako A/S, Glostrup, Denmark), the substrate 3-amino-9-ethylcarbazole was added to stain the pp65-positive cells. Finally, slides were examined microscopically and the results expressed as number of pp65positive cells per $5 \times 10^{4}$ granulocytes.

\section{Cell Culture}

For the detection of infectious CMV in blood, both conventional cell culture and detection of early antigen fluorescent foci (DEAFF) were performed, as described by Kraat et al. ${ }^{3}$ Leukocytes were purified from whole EDTA blood using dextran. Ap-

From the Departments of Medical Microbiology (V.J.G., M.J.B., C.A.B.) and Internal Medicine (M.H.L.C.), University Hospital Maastricht, Maastricht, The Netherlands; and NASBA Development Unit, Organon Teknika, Boxtel, The Netherlands (P.S., J.M.M.).

Address reprint requests to Dr Valère J. Goossens, Department of Medical Microbiology, University Hospital Maastricht, PO Box 5800, 6202 AZ, Maastricht, The Netherlands. 
Table 1. First Day of Detection of Cytomogalovirus

\begin{tabular}{|c|c|c|c|c|c|c|}
\hline Patient (Years/Month-Day/Gender) & $\begin{array}{l}\text { Serostatus Donor } \\
\text { and Receptor }\end{array}$ & IE1 mRNA & pp67 mRNA & $\begin{array}{c}\text { pp65 } \\
\text { antigenemia }\end{array}$ & PCR & Viral Culture \\
\hline \multicolumn{7}{|c|}{ (A) 7 positive patients detected by all methods } \\
\hline $37 / 11-29 / M$ & $D^{+} R^{-}$ & 25 & 35 & $35(259)^{*}$ & 28 & 32 \\
\hline $48 / 7-1 / \mathrm{M}$ & $D^{+} R^{-}$ & 16 & 30 & $27(168)^{*}$ & 27 & 27 \\
\hline $33 / 8-10 / F$ & $D^{+} R^{-}$ & 30 & 40 & $33(78)^{\star}$ & 30 & 26 \\
\hline $30 / 7-22 / \mathrm{M}$ & $D^{+} R^{-}$ & 48 & 48 & $48(68)^{*}$ & 48 & 48 \\
\hline 46/3-21/M & $D^{+} R^{-}$ & 44 & 55 & $44(10)^{*}$ & 44 & 44 \\
\hline $32 / 9-26 / \mathrm{M}$ & $D^{+} R^{+}$ & 15 & 26 & $22(58.4)^{\star}$ & 22 & 26 \\
\hline $60 / 8-16 / \mathrm{M}$ & $D^{-} R^{+}$ & 43 & 54 & $54(1.3)^{\star}$ & 43 & 54 \\
\hline Mean (range) & & $32(15-48)$ & $41(26-55)$ & $38(22-54)$ & $35(22-48)$ & $37(26-54)$ \\
\hline \multicolumn{7}{|c|}{ (B) 15 positive patients missed by at least one test } \\
\hline $81 / 11-25 / \mathrm{M}$ & $D^{+} R^{-}$ & 20 & Neg & Neg & 48 & Neg \\
\hline $39 / 2-5 / M$ & $D^{+} R^{-}$ & 23 & Neg & Neg & 26 & 26 \\
\hline 71/7-26/M & $\mathrm{D}^{+} \mathrm{R}^{-}$ & 54 & $\mathrm{Neg}$ & $\mathrm{Neg}$ & $\mathrm{Neg}$ & Neg \\
\hline $47 / 3-5 / F$ & $\mathrm{D}^{+} \mathrm{R}^{+}$ & 22 & $\mathrm{Neg}$ & $40(4)^{\star}$ & 36 & 36 \\
\hline 70/11-1/M & $\mathrm{D}^{+} \mathrm{R}^{+}$ & 37 & 37 & $\mathrm{Neg}$ & Neg & Neg \\
\hline $47 / 1-4 / F$ & $\mathrm{D}^{+} \mathrm{R}^{+}$ & 48 & 48 & $48(7)^{\star}$ & 48 & $\mathrm{Neg}$ \\
\hline 56/5-19/M & $\mathrm{D}^{+} \mathrm{R}^{+}$ & Neg & Neg & Neg & Neg & 26 \\
\hline $37 / 3-4 / F$ & $\mathrm{D}^{-} \mathrm{R}^{+}$ & 22 & Neg & Neg & Neg & $\mathrm{Neg}$ \\
\hline $46 / 6-21 / M$ & $\mathrm{D}^{-} \mathrm{R}^{+}$ & 28 & 52 & Neg & 35 & Neg \\
\hline $29 / 5-6 / M$ & $\mathrm{D}^{-} \mathrm{R}^{+}$ & 36 & Neg & $\mathrm{Neg}$ & $\mathrm{Neg}$ & Neg \\
\hline $48 / 6-17 / \mathrm{M}$ & $\mathrm{D}^{-} \mathrm{R}^{+}$ & 47 & 47 & Neg & $\mathrm{Neg}$ & $\mathrm{Neg}$ \\
\hline $69 / 3-24 / F$ & $D^{-} R^{-}$ & 1 & Neg & $\mathrm{Neg}$ & Neg & Neg \\
\hline $45 / 9-8 / F$ & $D^{-} R^{-}$ & 4 & 39 & $\mathrm{Neg}$ & $\mathrm{Neg}$ & Neg \\
\hline $54 / 7-20 / M$ & $\mathrm{D}^{-} \mathrm{R}^{-}$ & 28 & $\mathrm{Neg}$ & Neg & Neg & $\mathrm{Neg}$ \\
\hline $67 / 12-7 / F$ & $D^{-} R^{-}$ & Neg & Neg & Neg & 15 & Neg \\
\hline
\end{tabular}

${ }^{\star}$ Maximum number of positive cells per 50,000 granulocytes.

proximately $2 \times 10^{5}$ leukocytes were screened in duplicate for the presence of CMV by inoculation of human embryo fibroblast monolayers. Also, DEAFF was performed in duplicate after 2 days of cultivation, using monoclonal antibody E13 (Biosoft, Paris, France), which is directed against CMV IE antigen. The cell cultures were observed twice per week during a period of 6 weeks for the appearance of a typical cytopathic effect (CPE) of replicating CMV. After 3 weeks, cells were trypsinized and added to fresh fibroblast monolayers.

\section{RESULTS}

Of the 304 samples investigated, 87 samples were positive for at least one test. However, a cluster of 13 samples was contaminated with IE1 mRNA and was therefore not included in the analysis. Of the remaining 291 samples, 74 were positive for at least one test. Of these samples, 49 were positive for PCR, whereas 33 and 26 were positive for antigenemia and viral culture, respectively. There was a large difference in positivity between both NASBA tests, pp67 mRNA and IE1 mRNA, with 33 and 66 positive samples, respectively. Of the 30 patients investigated, 22 were positive for CMV (Table 1) in at least one test. Thirteen patients were positive for PCR compared to 9 and 10 positive patients for antigenemia and viral culture, respectively. NASBA found 12 patients to be positive for pp67 mRNA and 20 patients positive for IE1 mRNA. In 7 patients, all five tests used became positive at least once (Table 1, part A). The maximal values of antigenemia ranged from 1.3 to 259 (median 68). In these 7 patients, the first signs of CMV infection were detected slightly earlier by PCR (mean 35, range 22 to 48 ) than by viral culture (mean 37 , range 26 to 54 ) and antigenemia (mean 38, range 22 to 54). Results of the NASBA show that IE1 mRNA (mean 32, range 15 to 48 ) was detected earlier than pp67 mRNA (mean 41, range 26 to 55 ). In 15 other patients, at least one test failed to be positive (Table 1, part B). Also, in this group, IE1 NASBA became positive first and detected most patients. Eighteen of 291 samples were positive only for IE1 mRNA (Table 2). For 10 of these samples, the IE1 NASBA became positive prior to PCR. This difference resulted in 7 patients in a diagnostic advantage of 3 to 28 days. In 5 patients only IE1 mRNA was positive.

\section{DISCUSSION}

Several methods are available for early detection of CMV infection, the oldest of which is the conventional viral culture with CPE detection. In this study, 22 samples were positive with this test. A disadvantage of this test is that results can only be obtained after 1 to 6 weeks of culture. With DEAFF, results can be obtained after 2 days. In our study, only 11 samples were DEAFF-positive. The combination of conventional viral culture and shell viral culture resulted in culturing CMV in 26 samples. Antigenemia was positive in 33 samples. In agreement with an earlier study, ${ }^{1}$ we found a good correlation between the number of pp65-positive leukocytes and the clinical status of the patient before and after treatment with ganciclovir. 
Table 2. Confirmation of 18 samples positive only for IE1 mRNA

\begin{tabular}{|c|c|c|c|c|}
\hline $\begin{array}{c}\text { Patient } \\
\text { (Years/Month-Day/Gender) }\end{array}$ & Serostatus & $\begin{array}{c}\text { IE1 mRNA First Positive at } \\
\text { Day(s): }\end{array}$ & $\begin{array}{l}\text { Confirmation by Other Test(s) } \\
\text { First Positive at Day: }\end{array}$ & Difference (Days) \\
\hline \multirow[t]{2}{*}{$48 / 7-1 / M$} & \multirow[t]{2}{*}{$\mathrm{D}^{+} \mathrm{R}^{-}$} & \multirow[t]{2}{*}{16} & $27(P C R+A G+V C)^{*}$ & 11 \\
\hline & & & 30 (pp67) & 14 \\
\hline $81 / 11-25 / \mathrm{M}$ & $\mathrm{D}^{+} \mathrm{R}^{-}$ & 20 and 41 & 48 (PCR) & 28 \\
\hline $39 / 2-5 / M$ & $\mathrm{D}^{+} \mathrm{R}^{-}$ & 23 & $26(P C R+V C)$ & 3 \\
\hline \multirow[t]{3}{*}{$37 / 11-29 / M$} & \multirow{3}{*}{$D^{+} R^{-}$} & \multirow[t]{3}{*}{25} & 28 (PCR) & 3 \\
\hline & & & 32 (VCR) & 7 \\
\hline & & & $35(\mathrm{pp} 67+\mathrm{AG})$ & 10 \\
\hline \multirow[t]{2}{*}{$32 / 9-26 / M$} & \multirow[t]{2}{*}{$\mathrm{D}^{+} \mathrm{R}^{+}$} & \multirow[t]{2}{*}{15 and 19} & $22(P C R+A G)$ & 7 \\
\hline & & & $26(p p 67+V C)$ & 11 \\
\hline \multirow[t]{2}{*}{$47 / 3-5 / F$} & \multirow[t]{2}{*}{$\mathrm{D}^{+} \mathrm{R}^{+}$} & \multirow[t]{2}{*}{22 and 29} & $36(P C R+V C)$ & 14 \\
\hline & & & 40 (AG) & 18 \\
\hline \multirow[t]{2}{*}{$46 / 6-21 / M$} & \multirow[t]{2}{*}{$\mathrm{D}^{-} \mathrm{R}^{+}$} & \multirow[t]{2}{*}{28} & 35 (PCR) & 7 \\
\hline & & & 52 (pp67) & 24 \\
\hline $45 / 9-8 / F$ & $\mathrm{D}^{-} \mathrm{R}^{-}$ & 4 & 39 (pp67) & 35 \\
\hline $71 / 7-26 / M$ & $D^{+} R^{-}$ & 54 & - & \\
\hline $37 / 3-4 / F$ & $\mathrm{D}^{-} \mathrm{R}^{+}$ & 22,26 , and 29 & - & \\
\hline $29 / 5-6 / M$ & $\mathrm{D}^{-} \mathrm{R}^{+}$ & 36 & - & \\
\hline $69 / 3-24 / F$ & $D^{-} R^{-}$ & 1 & - & \\
\hline $54 / 7-20 / M$ & $D^{-} R^{-}$ & 28 & - & \\
\hline
\end{tabular}

${ }^{*} \mathrm{AG}$, antigenemia; VC, viral culture.

For several years, molecular diagnostic tests for detection of CMV viral pp67 mRNA, viral DNA, and viral immediate early 1 mRNA have also been available. The results obtained with the pp67 NASBA are very similar to those from viral culture and antigenemia. First, the numbers of samples and patients that were positive with these three different tests were almost similar, with pp67 mRNA having somewhat higher sensitivity. Second, the first day of positivity was similar for these three tests with means at days 37,38 , and 41 posttransplantation, respectively (Table 1, part A). However, a positive result for the viral culture will always take an additional 2 days to 6 weeks due to the required incubation time. pp67 NASBA missed only a few low positive antigenemias (with values of between 1.2 and 12.5) in five patients. But, in four of these five patients, the next sample, taken 3 to 4 days later, was positive by pp67 NASBA. Together, this makes pp67 NASBA a good equivalent for viral culture and antigenemia. PCR was positive in 49 samples and this was even higher than the 44 positive results with viral culture, antigenemia, and/or pp67 NASBA together. Fifteen patients (Table 1) were positive for viral culture, antigenemia, and/or pp67 NASBA. Of these 15 patients, 11 were positive for PCR including 6 high-risk transplantations $\left(\mathrm{D}^{+} \mathrm{R}^{-}\right)$and all antigenemia-positive patients. Of these 15 patients, 4 were PCR-negative, each of whom was a seropositive receptor with a low-risk transplantation and no antigenemia-positive results. However, based on 27 samples and 9 patients positive with other tests and negative for PCR, the sensitivity of PCR was not as high as expected. IE1 mRNA NASBA is a very sensitive diagnostic method for early detection of CMV after kidney transplantation. ${ }^{2}$ Also, in this study, more samples (66 of 291) were positive with IE1 NASBA than with any other method used. This means that, of 74 samples positive for one or more tests, $66(89 \%)$ were positive for IE1 NASBA. In almost all positive patients, IE1 NASBA was the first positive test. This is best illustrated in the group of seven patients positive for each test (Table 1, part A). In six of these patients, IE1 NASBA was the first positive test, whereas, in one patient, the result of the positive conventional culture was obtained only after IE1 NASBA was already positive. Also, in Table 1 (part B), IE1 NASBA was positive in 13 of 15 patients and, in each of these 13 patients, this was always the first positive signal. Thus, IE1 NASBA allowed early detection of ongoing CMV infection and brought forth an early-alert signal to the clinician. This allows for an intensified diagnostic investigation and, eventually, early antiviral treatment. Although IE1 NASBA seems to have advantages compared to the other tests, the significance of a positive IE1 NASBA is not always clear. As described previously by Blok et $\mathrm{al}^{2}{ }^{2} \mathrm{a}$ positive IE1 NASBA signal is not always an indication of an active infection with CMV. In five patients, only IE1 NASBA was positive, whereas all other tests remained negative. The relevance of these isolated positive samples remains to be clarified in further studies.

\section{CONCLUSION}

Viral culture, pp65-antigenemia, and the recently available pp67 mRNA NASBA were comparable for detection of $\mathrm{CMV}$ in our group of 30 renal transplant recipients. Both the first day of detection (means 37,38, and 41) and number of positive samples $(26,33$, and 33$)$ and positive patients $(10,9$, and 12) were similar for viral culture, pp65-antigenemia, and pp67 NASBA methods. Compared to these three tests, PCR performed better and detected CMV in 13 of 30 
renal transplant recipients. The difference was even greater when considering the detection of a total of 49 positive samples. Also, the first day of detection (mean 35) was slightly earlier for PCR. IE1 NASBA was the most sensitive test and detected approximately $90 \%$ of all positive samples and positive patients. In most patients, IE1 NASBA precedes PCR and all other positive results. This makes IE1 NASBA the first diagnostic clue for detection of CMV infection and permits intensified diagnostic investigation and, subsequently, early antiviral treatment. However, the significance of some positive IE1 NASBA results is not yet clear and needs further investigation. In conclusion, both PCR and IE1 NASBA are very promising for sensitive and early detection of CMV infection in renal transplant recipients.

\section{ACKNOWLEDGMENTS}

The authors thank Kees Vink for critical reading of the manuscript and helpful discussions. We also thank the technicians of the virology diagnostic lab for performing the antigenemia and viral culture analyses, and Bieke Vanherle for help with the PCR and NASBA assays.

\section{REFERENCES}

1. Blok MJ, Goossens VJ, Vanherle SJV, et al: J Clin Microbiol 36:1341, 1998

2. Blok MJ, Christiaans MHL, Goossens VJ, et al: Transplantation 67:1274, 1999

3. Kraat YJ, Christiaans MHL, Nieman FHM, et al: Transplant Int 7:362, 1994 
Chapter 3

\title{
DIAGNOSTIC VALUE OF NUCLEIC-ACID-SEQUENCE-BASED AMPLIFICATION FOR THE DETECTION OF CYTOMEGALOVIRUS INFECTION IN RENAL AND LIVER TRANSPLANT RECIPIENTS
}

\author{
Valère J. Goossens ${ }^{1}$, Marinus J. Blok ${ }^{1}$, Maarten H.L. Christiaans ${ }^{2}$, Johannes P. van Hooff ${ }^{2}$, \\ Peter Sillekens ${ }^{5}$, K. Hockerstedt ${ }^{4}$, Irmeli Lautenschlager ${ }^{3}$, Jaap M. Middeldorp ${ }^{5}$, \\ Cathrien A. Bruggeman ${ }^{1}$ \\ ${ }^{1}$ Department of Medical Microbiology, University Hospital Maastricht \\ ${ }^{2}$ Department of Internal Medicine, University Hospital Maastricht \\ ${ }^{3}$ Department of Virology, University Hospital Helsinki, Finland \\ ${ }^{4}$ Transplantation and Liver Surgery Unit, University Hospital Helsinki, Finland \\ ${ }^{5}$ Organon Teknika BV, Boxtel, The Netherlands
}





\title{
Diagnostic Value of Nucleic-Acid-Sequence- Based Amplification for the Detection of Cytomegalovirus Infection in Renal and Liver Transplant Recipients
}

\author{
Valère J. Goossens ${ }^{a}$ Marinus J. Blok ${ }^{a}$ Maarten H.L. Christiaans ${ }^{b}$ \\ Johannes P. van Hooff ${ }^{b}$ Peter Sillekens ${ }^{e}$ K. Höckerstedt ${ }^{d}$ \\ Irmeli Lautenschlager ${ }^{c}$ Jaap M. Middeldorpe Cathrien A. Bruggemana \\ a Department of Medical Microbiology and bepartment of Internal Medicine, University Hospital Maastricht, \\ Maastricht, The Netherlands; 'Department of Virology and dTransplantation and Liver Surgery Unit, \\ Department of Surgery, University Hospital Helsinki, Helsinki, Finland, and e Organon Teknika BV, \\ Boxtel, The Netherlands
}

\section{Key Words}

$\mathrm{CMV} \cdot$ Screening $\cdot \mathrm{mRNA} \cdot$ Immediate early gene products $\cdot$ pp $67 \cdot$ PCR $\cdot$ Antigenemia

\begin{abstract}
To evaluate the diagnostic value of nucleic-acid-sequence-based amplification (NASBA) for the detection of cytomegalovirus (CMV) infection in transplant recipients, we compared immediate early 1 (IE1) and late pp67 mRNA detection by NASBA with the antigenemia assay, $P C R$ and viral culture in 72 renal transplant (RTx) recipients and with antigenemia and serology in 25 liver transplant (LTX) recipients. Antigenemia, viral culture and pp67 NASBA were almost equivalent for the detection of CMV in RTx recipients. In LTx recipients, antigenemia detected more positive samples and more positive recipients compared to pp67 NASBA. In RTx recipients, PCR detected more positive samples and positive recipients compared to pp67 NASBA, antigenemia and viral culture. Also the first day of detection was slightly earlier for
\end{abstract} PCR. However, IE1 NASBA was the most sensitive test

The first two authors contributed equally to this work.

\begin{tabular}{ll}
\hline KARGER & (c) 2000 S. Karger AG, Basel \\
Fax + 41 61300-5526/99/0426-0373 $\$ 17.50 / 0$ \\
$\begin{array}{l}\text { E-Mail karger@karger.ch } \\
\text { www.karger.com }\end{array}$ & $\begin{array}{l}\text { Accessible online at: } \\
\text { www.karger.com/journals/int }\end{array}$
\end{tabular}

and detected $96 \%$ of all positive samples and positive transplant recipients. In addition, IE1 NASBA preceded PCR and all other positive results. This makes IE1 NASBA a very attractive screening test for the early detection of CMV infection.

Copyright (C) 2000 S. Karger AG, Basel

\section{Introduction}

Infection with human CMV is common and usually subclinical. However, serious CMV infection is possible in immunocompromised individuals, e.g. transplant recipients, HIV-infected patients and pregnant women [1]. After kidney, liver or other solid-organ transplantation, organ rejection occurs more frequently and a higher mortality rate is seen for $\mathrm{CMV}$-positive recipients compared to $\mathrm{CMV}$-negative recipients. The higher mortality rate as well as organ rejection can both be prevented by early antiviral treatment [2]. However, effective treatment requires an early diagnosis. In previous studies [3-5], we evaluated the diagnostic value of nucleic acid amplification tests for the early detection of CMV IE1 and late viral pp67 mRNA and viral DNA, using nucleic-acid-se-

Valère J. Goossens

Department of Medical Microbiology, University Hospital Maastricht PO Box 5800

NL-6202 AZ Maastricht (The Netherlands)

Tel. +31 4338 76644, Fax +314338 76643, E-Mail vvgo@lmib.azm.nl 
quence-based amplification (NASBA) and PCR, respectively. We compared these results with antigenemia, viral culture and/or serology. This comparison was done for either renal or liver transplant recipients. In this paper we report an overview of the results obtained for 97 transplant recipients of both groups and discuss the value of the methods used.

\section{Patients and Methods}

\section{Patients and Specimens}

Three groups of transplant recipients were studied. The first group consisted of 42 renal transplant recipients (RTx1). A total of 489 whole-blood samples were prospectively collected after kidney transplantations carried out at the Department of Internal Medicine, University Hospital Maastricht, between January 1995 and July 1996. The recipients could be grouped according to the CMV serostatus of the recipient $(\mathrm{R})$ and donor (D) before transplantation. This resulted in the following distribution of recipients over the different serogroups: $13 \mathrm{D}+/ \mathrm{R}+; 8 \mathrm{D}+/ \mathrm{R}-; 13 \mathrm{D}-/ \mathrm{R}+; 8 \mathrm{D}-/ \mathrm{R}-$. Heparinized whole-blood and serum specimens were collected weekly from inpatients and at every subsequent outpatient visit. Specimens were screened prospectively for the presence of CMV by viral culture and pp65 antigenemia. In addition, $1 \mathrm{ml}$ of heparinized blood was added to $9 \mathrm{ml}$ of NASBA lysis buffer and stored at $-70^{\circ}$ until analysis.

In a second group of 30 renal transplant recipients (RTx2), a total of 291 EDTA blood specimens were prospectively collected after kidney transplantations carried out at the Department of Internal Medicine, University Hospital Maastricht, between July 1997 and November 1997. All these samples were collected twice weekly during the first 2 months after transplantation. The $\mathrm{D} / \mathrm{R}$ serostatus distribution in $\mathrm{RT} 2$ was $6 \mathrm{D}+/ \mathrm{R}+$; $9 \mathrm{D}+/ \mathrm{R}-$; $8 \mathrm{D}-/ \mathrm{R}+; 7 \mathrm{D}-/ \mathrm{R}-$.

The third group consisted of 25 liver transplant recipients (LTX). A total of 291 blood samples were prospectively collected after liver transplantations carried out at the Helsinki University Hospital between December 1996 and November 1997. The D/R serostatus distribution in LTx recipients was $12 \mathrm{D}+/ \mathrm{R}+$; $4 \mathrm{D}+/ \mathrm{R}-$; $6 \mathrm{D}-/ \mathrm{R}+$; $2 \mathrm{D}-/ \mathrm{R}-; 1 \mathrm{D}$ ?/R+.

\section{pp65 Antigenemia Assay}

The pp65 antigen (ppUL83), a major early protein, was detected immunocytochemically in leukocytes isolated from whole-blood samples using antibodies directed against pp65. This assay was performed essentially as described by van der Bij et al. [6]. Briefly, leukocytes were isolated from whole blood and centrifuged onto a glass slide within $4 \mathrm{~h}$ after collection. The cells were subsequently fixed, and pp 65 was demonstrated by a monoclonal antibody and immunoperoxidase staining. Finally, the slides were examined microscopically. The results were expressed as the number of positive cells per 50,000 leukocytes.

\section{Viral Culture}

For the detection of infectious CMV in blood, both conventional cell culture with detection of cytopathic effect (CPE) and shell vial culture with detection of early antigen fluorescent foci (DEAFF) were performed as described previously [7]. Briefly, leukocytes were purified from whole blood using dextran. Approximately 200,000 leuko- cytes were screened in duplicate for the presence of CMV by inoculation of human embryo fibroblast monolayers. Cell cultures were observed twice a week during a period of 6 weeks for the appearance of a typical CPE on replicating CMV. Also DEAFF was performed in duplicate after 2 days of culture, using the monoclonal antibody E13 (Biosoft, Paris, France) to the CMV immediate early (IE) antigen. For analysis, DEAFF and CPE results were combined to give one outcome for the viral culture. The viral culture assays were routinely performed for the RTx recipients but not for the LTx recipients.

\section{Serology}

Sera of RTx1 and LTx recipients were tested retrospectively to obtain more information about viral activity, in addition to antigenemia and other assays. For the qualitative detection of IgM antibodies against $\mathrm{CMV}$ in serum, the $\mathrm{Im}^{\circledR} \mathrm{X} \mathrm{CMV}$ assay (Abbott Laboratories, Abbott Park, Ill., USA) was used, while IgG was semiquantitatively measured by AXSym ${ }^{\circledR}$ (Abbott). Both tests are based on the microparticle enzyme immunoassay (MEIA) technology.

\section{NASBA for pp67 $m R N A$ and IE $1 m R N A$}

Isolation, amplification and detection of pp67 mRNA, expressed from the UL65 open reading frame of human CMV, was done following the instructions of the manufacturer (NucliSens ${ }^{\circledR}$ CMV pp67 Organon Teknika, Boxtel, The Netherlands). The assay includes an internal system control (ISC) which serves as a positive control for isolation, amplification and detection; technical details are described elsewhere [3]. Isolation, amplification and detection of IE1 mRNA transcripts were done essentially as described for pp67 mRNA. Except that for the IE1 amplification two primers directed to exon 4 of the major IE gene were used. Also for IE1 NASBA, a specific ISC was developed [4].

\section{Polymerase Chain Reaction}

Detection of CMV DNA was done with Viral Quant ${ }^{\circledR}$, a quantitative PCR detection kit (BioSource, Etten-Leur, The Netherlands), following the instructions of the manufacturer. However, after adding 20,000 copies of the internal Calibration Standard (ICS) to each sample, nucleic acid isolation was performed essentially as described by Boom et al. [8]. The purified nucleic acids were resuspended in $200 \mu \mathrm{l}$ of sterile water of which $5 \mu \mathrm{l}$ was used for PCR. After an initial denaturation step at $95^{\circ}$ for $2.5 \mathrm{~min}$, the following temperature profile was used for 32 cycles: denaturing during $25 \mathrm{~s}$ at $94^{\circ}$, annealing during $25 \mathrm{~s}$ at $60^{\circ}$ and extension during $1 \mathrm{~min}$ at $72^{\circ}$. Due to our special interest for detection of CMV as early as possible, we used this PCR and microplate detection system only qualitatively at the lowest recommended dilution of 1:20 for detection of the amplified DNA and a dilution of 1:80 for the specific detection of the ICS copies.

\section{Definition of CMV infection}

To allow a comparison of the results of the three groups of transplant recipients to be made, CMV infection was defined by at least one positive result for one or more of the following items: antigenemia, viral culture, IE1 NASBA, p67 NASBA.

\section{Mathematics}

Diagnostic values, including sensitivities, specificities, positive predictive values (PPV) and negative predictive values (NPV) of IE1 NASBA, pp67 NASBA, viral culture and PCR were calculated with antigenemia as reference test. 
Table 1. RTx1, RTx2 and LTx recipients, and samples positive for antigenemia, viral culture, pp67 NASBA, PCR and IE1 NASBA

\begin{tabular}{|c|c|c|c|c|}
\hline Test & RTxl & $\mathrm{RT} \times 2$ & LTx & Total \\
\hline \multicolumn{5}{|l|}{ Viral culture } \\
\hline Positive samples & 36 & 26 & & \\
\hline Positive recipients, $\%$ & $36(15 / 42)$ & $33\left(10^{1 / 30)}\right.$ & not tested & $35(25 / 72)$ \\
\hline \multicolumn{5}{|l|}{ Antigenemia } \\
\hline Positive samples & 32 & 33 & 47 & 112 \\
\hline Positive recipients, $\%$ & $21(9 / 42)$ & $30(9 / 30)$ & $68(17 / 25)$ & $36(35 / 97)$ \\
\hline \multicolumn{5}{|l|}{ pp67 NASBA } \\
\hline Positive samples & 36 & 33 & 32 & 101 \\
\hline Positive recipients, $\%$ & $31(13 / 42)$ & $40(12 / 30)$ & $52(13 / 25)$ & $39(38 / 97)$ \\
\hline \multicolumn{5}{|l|}{$P C R$} \\
\hline Positive samples & & 49 & & \\
\hline Positive recipients, $\%$ & not tested & $43(13 / 30)$ & not tested & $43(13 / 30)$ \\
\hline \multicolumn{5}{|l|}{ IEI-NASBA } \\
\hline Positive samples & 164 & 66 & 132 & 362 \\
\hline Positive recipients, $\%$ & $62(26 / 42)$ & $67(20 / 30)$ & $88(22 / 25)$ & $70(68 / 97)$ \\
\hline \multicolumn{5}{|l|}{ Total } \\
\hline Positive samples & 167 & 74 & 136 & 377 \\
\hline Positive recipients, $\%$ & $64(27 / 42)$ & $73(22 / 30)$ & $88(22 / 25)$ & $73\left(71^{2} / 97\right)$ \\
\hline
\end{tabular}

Numbers of positive recipients are shown in parentheses.

1 In 1 RTx recipient, at the moment of sampling of the first positive viral culture, IE1 mRNA was still undetectable. However, at the time the positive result of the conventional culture became available, IE1 NASBA was already positive in later samples.

2 Only 3 RTx recipients, 2 with only 1 sample positive for viral culture, and 1 recipient with only 1 sample positive for PCR, were IE1 NASBA negative.

Table 2. Maximal antigenemia levels (expressed as number of positive cells per 50,000 leukocytes) detected in 18 RTx and 17 LTx recipients with primary or secondary infection

\begin{tabular}{llll}
\hline & RTx1 & RTx2 \\
\hline D+R- recipients & $67,14,8,1,0.33,0.33$ & $259,168,78,68,10$ & $100,85,50,50$ \\
D+R+ recipients & $15,3,0.33$ & $58,7,4$ & $150,100,50,40,30,30,20,20,10$ \\
D-R+ recipients & no positive results & 1 & $600,150,100,8$ \\
\hline
\end{tabular}

\section{Results}

Antigenemia was positive in 21,30 and $68 \%$ of 42 RTx1, 30 RTx2 and 25 LTx recipients, respectively (table 1). Antigenemia was also more frequently positive in primary $(65 \%, 15 / 23$ recipients) than in secondary infections (43\%, 20/47 recipients). For RTx recipients, the maximal detected levels for antigenemia were higher in 11 primary infections than in 7 secondary infections. In 17 LTx recipients, the maximal detected levels for antigenemia were high in both primary and secondary CMV

NASBA for CMV Detection in Transplant Recipients infections (table 2). In $18 \mathrm{RTx}$ recipients, primary and secondary CMV infections were detected by antigenemia at a mean of 40 days (range 22-69) after transplantation (table 3).

Viral culture was positive in $35 \%$ of $\mathrm{RTx}$ recipients (table 1$)$ and was more frequently positive in primary $(72 \%$, $13 / 18$ recipients) than in secondary infections $(40 \%, 12 /$ 30 recipients). Compared to antigenemia, the sensitivity, specificity, PPV and NPV of viral culture were respectively $89,86,69$ and $96 \%$ (table 4). In $16 \mathrm{RTx}$ recipients positive for both viral culture and antigenemia, primary and

Intervirology 1999;42:373-38 
Table 3. The onset of CMV infection (mean and range in parentheses), expressed as first day of positivity after transplantation, in $\mathrm{RTx}$ recipients as detected by viral culture (day of sampling), antigenemia, pp67 NASBA, PCR and IE1 NASBA

\begin{tabular}{llll}
\hline Test & RTx1 $(\mathrm{n}=26)$ & $\mathrm{RTx2}(\mathrm{n}=22)$ & Antigenemia+ $(\mathrm{n}=18)^{1}$ \\
\hline Viral culture & $43(19-69)$ & $35(26-54)$ & $38(23-69)$ \\
Antigenemia & $41(28-69)$ & $39(22-54)$ & $40(22-69)$ \\
pp67 NASBA & $42(21-75)$ & $43(26-55)$ & $42(26-75)$ \\
PCR & not tested & $35(15-48)$ & $35(22-48)$ \\
IE1 NASBA & $33(11-69)$ & $30(1-54)^{2}$ & $33(15-69)$ \\
\hline
\end{tabular}

Selection of antigenemia-positive recipients in both RTx groups.

2 IE1: 1 recipient was positive at day 1 , another at day 4 and 18 recipients became positive between day 15 and 54 after transplantation.
Table 4. Diagnostic values of viral culture, pp67 NASBA, PCR and IE1 NASBA compared to antigenemia in RTx1 $(n=42), \operatorname{RTx} 2(n=$ $30)$ and LTx $(n=25)$ recipients

\begin{tabular}{lcccc}
\hline Test and group & Sensitivity, $\%$ & Specificity, $\%$ & PPV, $\%$ & NPV, $\%$ \\
\hline Viral culture & & & & \\
RTx 1 & 89 & 82 & 57 & 96 \\
RTx2 & 89 & 90 & 80 & 95 \\
Mean & 89 & 86 & 69 & 96 \\
\hline pp67 NASBA & & & & \\
RTx 1 & 100 & 88 & 69 & 100 \\
RTx2 & 89 & 81 & 67 & 94 \\
LTx & 71 & 88 & 92 & 58 \\
Mean & 87 & 86 & 76 & 84 \\
\hline PCR & & & & \\
RTx2 & 100 & 81 & 69 & 100 \\
\hline IE1 NASBA & & & & \\
RTx1 & 100 & 55 & 38 & 100 \\
RTx2 & 100 & 48 & 45 & 100 \\
LTx & 100 & 38 & 77 & 100 \\
Mean & 100 & 47 & 53 & 100 \\
& & & &
\end{tabular}

secondary CMV infections were detected by viral culture (day of sampling) at a mean of 38 days (range 23-69) after transplantation (table 3). In the RTx group, combination of conventional cell culture and shell vial culture resulted in culturing CMV in 62 samples (table 1). Of these 62 positive samples, 58 (94\%) were detected by CPE and only 25 (40\%) were detected by DEAFF.

pp67 NASBA was positive in 31, 40 and 52\% of RTx 1 , RTx2 and LTx recipients (table 1), respectively, and was more frequently positive in primary infections $(70 \%, 16 /$ 23 recipients) than in secondary infections (47\%, 22/47 recipients). Compared to antigenemia, the sensitivity, specificity, PPV and NPV of pp67 NASBA were 87,86 , 76 and $84 \%$, respectively (table 4). In 17 RTx recipients positive for both pp67 NASBA and antigenemia, the primary and secondary CMV infection was detected by pp67 NASBA at a mean of 42 days (range 26-75) after transplantation (table 3). For renal transplant recipients, the results obtained with the pp67 NASBA are similar to those from viral culture (day of sampling) and antigenemia. First, the number of samples and recipients that were positive with these 3 different tests were almost similar (table 1). In about $80 \%$ of these samples, a positive result for pp67 NASBA, antigenemia or viral culture was confirmed by at least one of the other two tests. Secondly, the distribution of the first day of positivity is similar for these 3 tests (table 3). However, a positive result of the viral culture will always take an additional delay of 2 days (for DAEFF) to 6 weeks (for CPE) due to the required incubation time. Of 112 antigenemia positive samples, 44 were negative for pp67 NASBA (table 5), predominantly in samples with low antigenemia levels. However, in 6 LTx recipients, all treated with ganciclovir, also some pp67 NASBA-negative samples with high antigenemia results (up to 100) were seen.

PCR results were only available for the RTx 2 group. Of the $30 \mathrm{RTx} 2$ recipients, 13 (43\%) were positive for PCR (table 1). Compared to antigenemia, the sensitivity, specificity, PPV and NPV of PCR were respectively 100 , 81,69 and $100 \%$ (table 4). In $9 \mathrm{RT} 22$ recipients positive for both PCR and antigenemia, primary and secondary CMV infections were detected by PCR at a mean of 35 days (range 22-48) after transplantation (table 3). The number of RTx2 recipients positive for PCR (13) was not significantly different compared to antigenemia (9), viral culture (10) and pp67 NASBA (12). However, in these recipients, PCR was positive in 49 samples compared to 33, 26 and 33 samples for antigenemia, viral culture and 

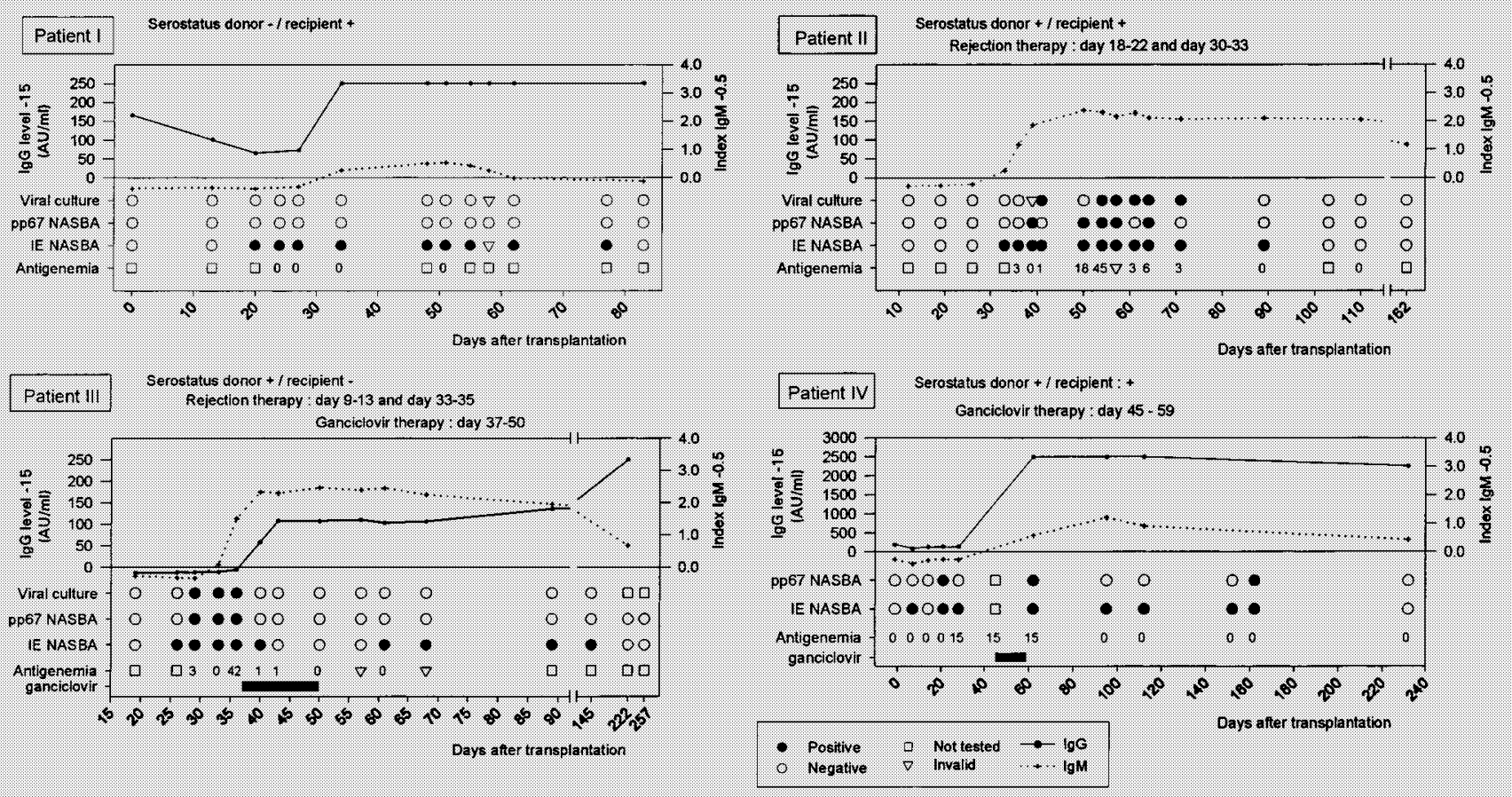

Fig. 1. Typical examples of results obtained by the pp65 antigenemia assay, viral culture, serology, IE1 and pp67 NASBA in 3 RTx recipients (patients I, II and III) and 1 LTx recipient (patient IV). In RTx recipients, the indicated rejection therapy consisted of three doses of methylprednisolone. To indicate very low antigenemia levels, the antigenemia results are expressed as the number of pp65-positive cells per 150,000 leukocytes. Results from the ImX CMV assay were expressed as index values. Sera with IgM index values $\geq 0.500$ were

pp67 NASBA, respectively (table 1). PCR detected even more positive samples (49) than the 44 positive samples obtained with viral culture, antigenemia and/or pp67 NASBA together. Fifteen RTx2 recipients were positive for viral culture, antigenemia and/or pp67 NASBA. Of these 15 recipients, 11 were positive for PCR including all (6) high-risk transplantations (D+R-) and all (9) antigenemia-positive recipients.

IE1 NASBA was positive in 62,67 and $88 \%$ of RTx 1 , RTx2 and LTx recipients, respectively (table 1), and was detected in almost all primary $(96 \%, 22 / 23$ recipients) and secondary (98\%, 46/47 recipients) CMV infections. Compared to antigenemia, the sensitivity, specificity, PPV and NPV of IE1 NASBA were 100, 47, 53 and 100\%, respectively (table 4). In 18 RTx recipients positive for both IE1 NASBA and antigenemia, CMV infection was detected by IE1 NASBA at a mean of 33 days (range 1569 ) after transplantation (table 3). In 94\% (46/49) of pos-

itive RTx and in all 22 positive LTx recipients, IE1 NASBA was the first test to become positive. IE1 NASBA could detect CMV several days to several weeks before all other tests, and especially in individual RTx recipients, this diagnostic advantage was up to 28 days compared to viral culture (day of sampling), antigenemia and PCR and up to 35 days compared to pp67 NASBA. Of all samples positive for at least one test, $96 \%(362 / 377)$ were detected by IE1 NASBA (table 1). In the three groups of RTx1, RTx2 and LTx recipients, there were samples that were only positive for IE1 NASBA. In part, these positive IE1 NASBA results were confirmed later on by other tests, including pp67 NASBA, antigenemia, viral culture and PCR. In other recipients, positive IE1 NASBA results could not be confirmed by antigenemia, viral culture or pp67 NASBA, but were confirmed by a serological response with the appearance of anti-CMV IgM antibodies and/or a significant increase in anti-CMV

NASBA for CMV Detection in Transplant

Intervirology 1999;42:373-381

considered positive. The levels of anti-CMV IgG were expressed as s $\geq 15 \mathrm{AU} / \mathrm{ml}$ were considered positive. The viral culture result ent (DEAFF and CPE results were combined to give a single outcome for viral culture). In patient III and IV, the black line indicates the period of antiviral therapy with ganciclovir. 
Table 5. Distribution of 134 samples positive for antigenemia (112) and/or pp67 NASBA (90)

\begin{tabular}{|c|c|c|c|c|c|c|c|c|}
\hline & \multicolumn{2}{|l|}{ RTXI } & \multicolumn{2}{|l|}{$\mathrm{RT} \times 2$} & \multicolumn{2}{|l|}{ LTx } & \multicolumn{2}{|l|}{ Total } \\
\hline & pp67+ & pp67- & pp $67+$ & pp67- & pp $67+$ & pp67- & pp67+ & pp67- \\
\hline \multicolumn{9}{|l|}{ Antigenemia negative } \\
\hline pp67 NASBA-positive samples & 7 & & 6 & & 9 & & 22 & \\
\hline \multicolumn{9}{|c|}{ Antigenemia result between 0.1 and 3.0} \\
\hline pp67 NASBA-positive samples & 11 & & 8 & & 0 & & 19 & \\
\hline pp67 NASBA-negative samples & & 14 & & 3 & & 3 & & 20 \\
\hline \multicolumn{9}{|c|}{ Antigenemia result between 3.1 and 10.0} \\
\hline pp67 NASBA-positive samples & 4 & & 8 & & 7 & & 19 & \\
\hline pp67 NASBA-negative samples & & 0 & & 2 & & 15 & & 17 \\
\hline \multicolumn{9}{|c|}{ Antigenemia result between 10.1 and 30.0} \\
\hline pp67 NASBA-positive samples & 2 & & 3 & & 3 & & 8 & \\
\hline pp67 NASBA-negative samples & & 0 & & 1 & & 4 & & 5 \\
\hline \multicolumn{9}{|l|}{ Antigenemia result higher than 30.0} \\
\hline pp67 NASBA-positive samples & 1 & & 8 & & 13 & & 22 & \\
\hline pp67 NASBA-negative samples & & 0 & & 0 & & 2 & & 2 \\
\hline Total & 25 & 14 & 33 & 6 & 32 & 24 & 90 & 44 \\
\hline
\end{tabular}

IgG antibodies (see patient I in fig. 1). In patient II in figure 1, the first and the last positive IE1 NASBA results were not confirmed by other tests. Also after treatment with ganciclovir, for several weeks to months (see patients III and IV in fig. 1), samples were positive only for IE1 NASBA and negative for antigenemia and viral culture.

\section{Discussion}

Several methods are available for the early detection of CMV infection. The oldest one is the conventional cell culture with CPE detection. A disadvantage of this test is that the results are obtained only 1-6 weeks after starting the culture. Using shell vial culture with DEAFF, results can be obtained within 2 days, but the number of positive samples is low. This means that for the early detection of CMV in RTx recipients, detection by CPE takes too long for clinical use and detection by DEAFF is too insensitive. Especially for blood cultures, such a difference between DEAFF and CPE has already been described [1]. The sensitivity of shell vial culture can probably be improved by increasing the number of polymorphonuclear leukocytes inoculated [9]. It is also important to reduce the transport time of specimens prior to culture to avoid false-negative culture results [10].
Due to its diagnostic accuracy, rapidity, quantitative nature and technical simplicity, the antigenemia assay is one of the cornerstone methods for diagnosis and management of active CMV infection in immunocompromised patients [11] and attempts are made at its standardization [12]. Besides this, the antigenemia assay was the only method used in both the RTx1 and RTx2 groups and in the LTx group. For both reasons, we used the antigenemia assay as the 'golden standard' to compare with viral culture, pp67 NASBA, PCR and IE1 NASBA. The described results of antigenemia-positive samples and recipients and a different distribution among RTx recipients with primary or secondary infection (table 5) are in agreement with others [13]. In our RTx and LTx recipients, a good correlation was also found between the number of pp65positive leukocytes and the clinical status of the recipient before and after treatment with ganciclovir (see for example patients III and IV in figure 1).

Detection of CMV late viral pp67 mRNA using the NASBA methodology has been possible for several years already [14]. For RTx recipients, pp67 NASBA is at least equivalent to antigenemia and viral culture. However, in LTx recipients more than in $\mathrm{RTx}$ recipients, antigenemiapositive but pp67 NASBA-negative samples were seen (table 5). Two main situations are responsible for the presence of such pp67-NASBA-negative, antigenemia-positive samples. First, this can happen very early in the infec- 
tion. However, this does not need to be a problem in clinical practice. This was demonstrated in $4 \mathrm{RTx}$ recipients in our study with one sample being negative for pp67 NASBA, but in each recipient already the next sample, taken 3-4 days later, was positive for pp67 NASBA. Secondly, after antiviral therapy, there is a difference in the disappearance of the antigenemia and the pp67 NASBA signals. Upon initiation of antiviral therapy, there is a block in the viral replication cycle and in the production of pp67 mRNA, a true late $(\gamma)$ marker. Due to the instability of mRNA, pp67 NASBA will soon become negative while the stabler pp65 protein is still present in polymorphonuclear leukocytes. In addition, the pp65 protein is transcribed from UL83, a gene with $\beta / \gamma$ characteristics [15], and cannot be considered a true late marker. Therefore, low levels of pp65 antigen cannot be used to monitor therapeutic efficacy. In general, for RTx recipients, pp67 NASBA is equivalent to antigenemia and viral culture for the early detection of CMV infection. In LTX recipients with primary CMV infection, all 4 recipients were positive for both antigenemia and pp67 NASBA. In LTx recipients with secondary CMV infection, pp67 NASBA was less frequently positive (47\%, 9/19 recipients) compared to antigenemia $(68 \%, 13 / 19$ recipients). This difference between pp67 NASBA and antigenemia in RTx and LTx recipients is most probably due to more frequent and early use of antiviral products in LTx recipients. It also reflects the great difference in clinical status and immunosuppression between RTx and LTx recipients. Especially LTx recipients are heavily immunosuppressed and are much more easily treated for CMV, because they are more at risk of developing a life-threatening infection. In fact, antiviral therapy with ganciclovir was given to $72 \%(18 /$ 25 ) of the LTx recipients (including all 15 recipients with symptomatic CMV infection and 3 recipients with ganciclovir prophylaxis during antirejection treatment) compared to only $14 \%(6 / 42)$ of the RTx 1 recipients.

Within the RTx2 group, PCR detected all the (high) risk recipients. These findings are in agreement with other results obtained with the same quantitative CMV DNA detection method [16]. However, due to 27 samples and 9 recipients positive for other tests but negative for PCR, the analytical sensitivity of PCR was not as expected. This is probably also the reason why the manufacturer modified the method afterwards by lowering the number of added ICS copies and increased the number of cycles. With this modified method, samples containing at least 3 copies per amplification (600 copies/ml) were detectable [16]. However, in general, the diagnostic value of monitoring CMV DNA remains in dispute, considering the

NASBA for CMV Detection in Transplant Recipients life-long persistence of CMV in the circulatory compartment.

IE1 mRNA NASBA is a very sensitive diagnostic method for the early detection of CMV activity after renal or liver transplantation. Of $22 \mathrm{LTx}$ recipients and $45 \mathrm{RTx}$ recipients positive for at least one test, only 3 were missed by IE1 NASBA. However, in these 3 RTx recipients, with only one sample positive for only one test, contamination of viral culture or PCR could not be excluded. In general, in RTx and LTx recipients, IE1 NASBA allows the quickest detection of an ongoing CMV infection, bringing an early alerting signal to the clinician. This permits an intensified diagnostic monitoring and possibly early antiviral treatment to be performed. Recently, with the quantification of IE1 and pp67 mRNA levels, differences between pp67 NASBA, antigenemia and IE1 NASBA became clearer [17]. In lung transplant recipients, IE1 NASBA became detectable days before pp67 NASBA and antigenemia. This was the result of a much higher level of IE1 mRNA. When antigenemia-positive cells or pp67 mRNA levels become detectable $(\geqslant 100$ pp67 mRNA molecules per milliliter), IE1 mRNA levels already exceed 10,000 mRNA molecules per milliliter. In addition, relapsing infection and ineffective therapy were paralleled by persisting IE1 mRNA levels $(>5,000 / \mathrm{ml})$, which disappeared only upon complete resolution of the infection. However, high IE1 mRNA levels were also observed in some patients whose CMV infection remained subclinical. The difference in the detectable level of 100 IE1 mRNA molecules per milliliter for NASBA [17] and in the detectable level of 600 copies of DNA molecules per milliliter for PCR [16] also contributes to higher numbers of samples and recipients being positive for IE1 NASBA compared to PCR.

Although IE1 NASBA has advantages compared to other tests, the significance of a positive IE1 NASBA is not always clear. In all three transplant recipient groups, a positive signal with IE1 NASBA was not always an indication of an active or symptomatic infection with CMV (e.g. patient I in fig. 1). The question can be raised whether IE1 NASBA is perhaps too sensitive for practical use and detects too many asymptomatic or subclinical infections. Indeed, some IE1 NASBA results could not be confirmed by other tests. On the other hand, no IE1 mRNA is detectable in healthy virus carriers [Middeldorp et al., in preparation]. In addition, there is increasing evidence that the presence of $\mathrm{IE}$ and/or E gene products is a key factor in some aspects of the pathogenesis of CMV infection. CMV infections cause major infectious complications after organ transplantation, and a variety of clinical manifesta- 
tions, such as fever, leukopenia, thrombopenia, encephalitis, retinitis, pneumoniae, hepatitis and glomerulopathy, have been described [18]. In kidney allografts, vascular changes, glomerulosclerosis and tubular atrophy are associated with chronic rejection, but the most characteristic long-term finding is interstitial fibrosis [19]. Some of these complications and findings can not be explained by productive viral replication with synthesis of new viral DNA and late gene products as structural viral proteins and resulting in 'virus plaques' in tissues with consequent loss of tissue and tissue function. More important is the activity of the immediate early and/or early gene products inducing many proinflammatory activities along with cytokines, chemokines and upregulation of adhesion molecules [20]. Also immune escape phenomena are already present in the immediate early/early phase [21]. In addition, sequence homology and immunologic cross-reactivity of immediate early antigens and HLA-DR antigens have been demonstrated [22]. At this moment, the clinical significance of the detection of IE1 mRNA with the IE1 NASBA is not fully understood, especially in patients negative for antigenemia/viral culture with or without antiviral prophylaxis or treatment. However, in the near future with the increasing prophylactic and therapeutic use of DNA-polymerase-blocking antiviral products, IE1 and other immediate early/early gene products can 'build up' behind the block of viral DNA synthesis [20]. Thereby, this antiviral block could extend and accentuate rather than prevent inflammatory responses, possibly leading to delayed or more chronic complications in the posttransplantation period.

\section{Conclusion}

Viral culture, pp65 antigenemia and late pp67 mRNA detection by NASBA are almost equivalent in the detection of CMV in RTx recipients, Not only the first day of detection, but also the number of positive samples and positive recipients are similar for viral culture, pp65 antigenemia and pp67 NASBA. PCR detected CMV in more samples and in more recipients than did these three tests. Also the first day of detection was slightly earlier for PCR. However, PCR missed some recipients that were positive in the other tests.

In RTx and LTx recipients, IE1 NASBA was the most sensitive test and detected $96 \%$ of the positive samples and positive recipients. In most recipients, IE1 NASBA precedes PCR and all other positive results. This makes IE1 NASBA a very attractive screening test for the detection of CMV infection and allows an intensified diagnostic investigation to be performed with possibly early antiviral treatment. With the high sensitivity and NPV of IE1 NASBA, a negative result rules out a CMV infection. However, the clinical significance of some positive IE1 NASBA results is not yet clear and needs further investigation. Therefore, at the moment, a positive IE1 NASBA should be used in combination with assays that are more specific for the detection of symptomatic CMV infection. As representative for immediate early gene and early gene products, IE1 NASBA may also provide more insight into the pathogenesis of CMV-related immunopathology.

\section{References}

1 Britt WJ, Alford CA: Cytomegalovirus; in Fields BN, Knipe DM, Howley PM (eds): Fields Virology. New York, Lippincott-Raven, 1996, pp 2493-2523.

2 Patel R, Snydman DR, Rubin RH, Ho M, Pescovitz M, Martin M, Paya CV: Cytomegalovirus prophylaxis in solid organ transplant recipients. Transplantation 1996;61:1279-1289.

3 Blok MJ, Goossens VJ, Vanherle SJV, Top B, Tacken N, Middeldorp JM, Christiaans MH, Van Hooff J, Bruggeman CA: Diagnostic value of monitoring human cytomegalovirus late pp67 mRNA expression in renal-allograft recipients by nucleic acid sequence-based amplification. J Clin Microbiol 1998;36:1341-1346.
4 Blok MJ, Christiaans MHL, Goossens VJ, Van Hooff JP, Sillekens P, Middeldorp JM, Bruggeman CA: Early detection of human cytomegalovirus infection after kidney transplantation by nucleic acid sequence-based amplification. Transplantation 1999;67:1274-1277.

5 Goossens VJ, Blok MJ, Christiaans MHL, Sillekens P, Middeldorp JM, Bruggeman CA: Early detection of cytomegalovirus in renal transplant recipients: Comparison of PCR, NASBA, pp65-antigenemia and viral culture. Transplant Proc, in press.

6 Van der Bij W, Schirm J, Torensma R, Van Son WJ, Tegzess AM, The TH: Comparison between viremia and antigenemia for detection of cytomegalovirus in blood. J Clin Microbiol 1988;26:2531-2535.
7 Kraat YJ, Christiaans MHL, Nieman FHM, van den Berg-Loonen PM, van Hooff JP, Bruggeman CA: Risk factors for cytomegalovirus infection and disease in renal transplant recipients: HLA-DR7 and triple therapy. Transplant Int 1994;7:362-367.

8 Boom R, Sol CJA, Salimans MMM, Jansen CL, Wertheim-van Dillen PME, van der Noordaa $\mathbf{J}$ : Rapid and simple method for purification of nucleic acids. J Clin Microbiol 1990;28:495503.

9 Reina J, Saurina J, Fernandez-Baca V, Blanco I, Munar M: An increase in the number of polymorphonuclear leukocytes inoculated on shellvial culture increases the sensitivity of this assay in the detection of cytomegalovirus in the blood of immunocompromised patients. Diagn Microbiol Infect Dis 1998;31:425-428. 
10 Roberts TC, Buller RS, Gaudreault-Keener M, Sternhell KE, Garlock K, Singer GG, Brennan DC, Storch GA: Effects of storage temperature and time on qualitative and quantitative detection of cytomegalovirus in blood specimens by shell vial culture and PCR. J Clin Microbiol 1997;35:2224-2228.

11 The TH, Harmsen MC, Van der Bij W, Van den Berg AP, Van Son WJ: Relationship between monitoring the viral load in blood, human cytomegalovirus pathophysiology and management strategies of patients after transplantation. Monogr Virol. Basel. Karger, 1998, vol 21, pp 270-279.

12 The TH, Van den Berg AP, Harmsen MC, Van der Bij W, Van Son WJ: The cytomegalovirus antigenemia assay: A plea for standardization. Scand J Infect Dis 1995; suppl 99:25-29.

13 Sharma AK, Taylor JD, Tong W, Brown MW, Sells RA, Bakran A: Utility of the pp65 direct antigenemia test in the diagnosis of cytomegalovirus (CMV) in renal transplant recipients. Transplant Proc 1997;29:799.
14 Gerna G, Baldanti F, Middeldorp JM, Furione M, Zavattoni M, Lilleri D, Revello MG: Clinical significance of expression of human cytomegalovirus pp67 late transcript in heart, lung, and bone marrow transplant recipients as determined by nucleic acid sequence-based amplification. J Clin Microbiol 1999;37:902-911.

15 Grefte JM, Van der Gun BT, Schmolke S, Van der Giessen M, Van Son WJ, Plachter B, Jahn $\mathrm{G}$, The TH: The lower matrix protein pp65 is the principal viral antigen present in peripheral blood leukocytes during an active cytomegalovirus infection. J Gen Virol 1992;73:29232932.

16 Reagen KJ, Cabradilla C, Shuman B, Stollar N, Laudemann J, Bai X, Hosler G, Scheuermann RH: Analytical performance of a quantitative CMV DNA detection method. Monogr Virol. Basel, Karger, 1998, vol 21, pp 252-261.

17 Middeldorp J: Direct quantification of human cytomegalovirus (HCMV) immediate early and late mRNA levels in the blood of HCMVinfected individuals using competitive NASBA (abstract G0-21) 7th Int Cytomegalovirus Workshop, Brighton, April 1999. J Clin Virol 1999; $12: 103$
18 Rubin RH: Impact of cytomegalovirus infection on organ transplant recipients. Rev Infect Dis 1990;12(suppl 7):S754-S766.

19 Lautenschlager I: Role of cytomegalovirus infection in the process of organ allograft rejection. Monogr Virol. Basel, Karger, 1998, vol 21, pp 142-157.

20 Grundy JE: Current antiviral therapy fails to prevent the pro-inflammatory effects of cytomegalovirus infection, whilst rendering infected cells relatively resistant to immune attack. Monogr Virol. Basel, Karger, 1998, vol 21, pp 67-89.

21 Miller DM, Sedmak DD: Cytomegalovirus persistence: escape from cell-mediated immunosurveillance. Monogr Virol. Basel, Karger, 1998, vol 21, pp 1-11.

22 Fujinami RS, Nelson JA, Walker L, Oldstone MBA: Sequence homology and immunologic crossreactivity of human cytomegalovirus with HLA-DR chain: A means for graft rejection and immunosuppression. J Virol 1988;62:100105 . 
Chapter 4

\title{
DIFFERENT PROFILES OF CYTOMEGALOVIRUS RNA TRANSCRIPTS AND ANTI-CYTOMEGALOVIRUS IgM ANTIBODIES IN RENAL TRANSPLANT RECIPIENTS
}

\author{
Valère J. Goossens ${ }^{1,2}$, Cornelis Vink ${ }^{1,2}$, Will Mullers ${ }^{1,2}$, Jaap M. Middeldorp ${ }^{3}$, \\ Cathrien A. Bruggeman ${ }^{1,2}$ \\ ${ }^{1}$ Department of Medical Microbiology, University Hospital Maastricht \\ ${ }^{2}$ Cardiovascular Research Institute Maastricht, University of Maastricht \\ ${ }^{3}$ Department of Pathology, University Hospital Vrije Universiteit, Amsterdam
}

Journal of Clinical Virology 2001; 23: 87-95 



\title{
Different profiles of cytomegalovirus RNA transcripts and anti-cytomegalovirus IgM antibodies in renal transplant recipients
}

\author{
V.J. Goossens a,b,*, C. Vink ${ }^{a, b}$, W. Mullers a,b , J.M. Middeldorp ${ }^{c}$, \\ C.A. Bruggeman ${ }^{\mathrm{a}, \mathrm{b}}$ \\ ${ }^{a}$ Department of Medical Microbiology, University Hospital Maastricht, PO Box 5800, 6202 AZ, Maastricht, The Netherlands \\ ${ }^{\mathrm{b}}$ Cardiovascular Research Institute Maastricht, University of Maastricht, Maastricht, The Netherlands \\ ${ }^{\mathrm{c}}$ Department of Pathology, University Hospital Vrije Universiteit, Amsterdam, The Netherlands
}

Received 13 March 2001; accepted 4 June 2001

\begin{abstract}
Background: a difference in anti-cytomegalovirus $\operatorname{IgM}$ antibody profile has been found between sera from acutely cytomegalovirus (CMV)-infected patients and sera from CMV-infected patients with subclinical infection. Objectives: the aim of this study is to investigate whether such different IgM antibody responses are correlated with differences in the expression of CMV immediate early and late mRNAs. Study design: we have investigated the anti-CMV IgM response in 46 renal transplant recipients by employing two commercially available IgM kits (AxSYM and IMX) as well as two novel enzyme-linked immunosorbent assays (ELISAs), which were developed using recombinant ppUL32 (pp150) and pUL80a (p38), respectively. The results were compared with four direct CMV diagnostic tests: pp65 antigenemia, viral culture and nucleic acid sequence-based amplification (NASBA), detecting either CMV immediate early 1 (IE1) mRNA (IE1-NASBA), or CMV pp67 (late) mRNA (pp67-NASBA). Results: analysis of all CMV-infected recipients $(n=28)$ showed that in 16 recipients (group I) more than one direct test became positive after transplantation, while in the other 12 recipients (group II), IE1-NASBA was the only direct test to become positive. In group I, 100, 81, 100 and 50\% of the recipients were IgM-positive with AxSYM, IMX, p38 and pp150, respectively. In group II, 100, 83, 17 and $83 \%$ of the recipients were IgM-positive with AxSYM, IMX, p38 and pp150, respectively. Conclusions: our data indicate that the IgM-response against p38 and pp150 differs significantly $(P<0.01)$ between group I recipients with productive CMV infection, and group II recipients with a non-productive CMV infection which may be of diagnostic and prognostic relevance. (C) 2001 Elsevier Science B.V. All rights reserved.
\end{abstract}

Keywords: CMV; UL32; UL80; Immediate early; pp67; NASBA

\footnotetext{
Abbreviations: CMV, cytomegalovirus; DEAFF, detection of early-antigen fluorescent foci; HCMV, human cytomegalovirus; IE1, immediate early 1; NASBA, nucleic acid sequence-based amplification; PCR, polymerase chain reaction.

* Corresponding author. Tel.: + 31-43-3876644; fax: + 31-43-3876643.

E-mail address: vvgo@lmib.azm.nl (V.J. Goossens).
}

1386-6532/01/\$ - see front matter (C) 2001 Elsevier Science B.V. All rights reserved.

PII: S1386-6532(01)00190-1 


\section{Introduction}

Cytomegalovirus (CMV) is an ubiquitous virus. Most infections with CMV occur without clinical symptoms. However, in immunocompromised individuals, such as organ transplant recipients, the virus may induce life-threatening disease. With the introduction of effective anti-CMV therapies, such as treatment with ganciclovir (Erice et al., 1987) and foscarnet (Knox et al., 1991), early diagnosis and differentiation between subclinical and high risk systemic productive infection is essential for effective clinical management of infection. Systemic productive infection is directly related with disease development and requires antiviral treatment. On the other hand, CMV infection frequently remains limited to early stages of infection not leading to disease and may be left untreated (Middeldorp et al., 2000; Vivarelli et al., 2000).

Specific diagnosis of active CMV infection is based on different approaches. The most direct approach is detection of infectious virus in patient material such as blood. While detection of infectious virus in blood leukocytes by either culture or shell vial assay (Gleaves et al., 1987) is still widely used, other more sensitive and/or more rapid direct detection techniques have been developed. Among them, detection of CMV lower matrix protein, pp65, in polymorphonuclear leukocytes (PMNL) was shown to be an early marker of active CMV infection (Gerna et al., 1991; The et al., 1990). Other assays are based on the polymerase chain reaction (PCR) and were used to detect viral DNA in leukocytes (Cope et al., 1997; Fox et al., 1992; Zipeto et al., 1992). More recently, detection of viral mRNA by RT-PCR or by nucleic acid sequence based amplification (NASBA) has proven to be a sensitive and powerful method for early detection of CMV infections. In particular, detection of CMV pp67 mRNA by NASBA was shown to be a sensitive marker for monitoring CMV infections in transplant recipients (Blok et al., 1998; Gerna et al., 1999; Oldenburg et al., 2000). Detection of CMV IE1 mRNA by NASBA was reported to have an even higher sensitivity (Goossens et al., 2000), although this sensitivity may be too high for clinical purposes, detecting many non-symptomatic or subclinical infections (Goossens et al., 1999).

In addition to direct assays for detecting CMV nucleic acids or protein, CMV infection can also be diagnosed indirectly through serology. CMVspecific immunoglobulin (Ig) $\mathrm{M}$ is a sensitive and specific indicator of active CMV infection, and is produced during primary infection and occasionally during reactivation of latent virus (Basson et al., 1989; Landini, 1993; Landini et al., 1995; Lazzarotto et al., 1998; Nielsen et al., 1988; Schoppel et al., 1998). Commercially available serologic assays are widely used to support diagnosis of CMV infection. However, detection of CMV IgM antibodies varies between the different commercial tests, most likely due to the use of different CMV antigens (Kraat et al., 1993). The use of viral lysates obtained from culture lysates of CMV infected fibroblasts, can lead to potential contamination with cellular proteins, resulting in false-positive reactions. The use of well-defined antigens can overcome such reactions (Greijer et al., 1999; Landini et al., 1995). In addition, the use of single, well-characterised viral proteins as antigens might provide more detailed insight in the immune response against the virus. Recombinant DNA technology offers the opportunity to generate specific viral antigens which are known to be prominent targets of the humoral response and may improve serodiagnostic procedures.

In this report, we describe the development and potential clinical use of two novel immunological assays (ELISAs) to detect anti-CMV IgM antibodies. The assays were generated using recombinant human CMV proteins containing parts of either the UL32-encoded basic phosphoprotein (ppUL32 or pp150) or the UL80a-encoded capsid assembly protein ( $\mathrm{pUL80a}$ or $\mathrm{p} 38$ ). The choice of p38 (pUL80a) and pp150 (ppUL32) recombinant proteins containing immunoreactive amino acid sequences is based on results of a preceding study (Kraat et al., 1996), in which it was shown that during acute CMV infections predominantly IgM antibodies against pp150 and p38 are developed. The two novel ELISAs were evaluated in a group of renal transplant recipients and compared with two commercially available anti-CMV IgM ELISAs as well as with several direct tests to 
detect CMV, including pp65 antigenemia, viral culture and nucleic acid sequence-based amplification (NASBA).

\section{Materials and methods}

\subsection{Patients and virologic monitoring}

The study group consisted of 46 patients who underwent renal transplantation in the Academic Hospital Maastricht, The Netherlands. All recipients were prospectively monitored for CMV infection on the basis of viral culture, pp65 antigenemia, IE1-NASBA and pp67-NASBA as described by Blok et al. (1998, 1999). As controls, serum samples from healthy blood donors obtained from a local transfusion centre (Red Cross Blood Centre, Hasselt, Belgium) were used.

For virologic monitoring of CMV infection, blood samples for detection of CMV infection in leukocytes were collected weekly during the hospitalisation period. Thereafter, the recipients were followed monthly. When clinical symptoms occurred, blood was again collected on a weekly basis. The recipients were followed during a period of up to 9 months post transplantation. Sera for antibody assays were collected and stored at $-70{ }^{\circ} \mathrm{C}$ until use.

\subsection{Antigenemia}

The presence of CMV pp65 (ppUL83) in polymorphonuclear leukocytes was determined as originally described by Van der Bij et al. (1988) using CMV pp65-specific monoclonal antibodies. The assay was performed as described by Blok et al. (1998).

\subsection{Detection of infectious virus}

For detection of infectious virus in blood leukocytes, both conventional cell culture and shell vial assay were performed as described earlier (Kraat et al., 1994). The cell cultures were observed weekly during a period of 6 weeks for the appearance of a cytopathic effect. In the shell vial assay, detection of early-antigen fluorescent foci
(DEAFF) was carried out by using monoclonal antibodies directed against IE1 antigen of CMV (monoclonal antibody E13; Biosoft, Paris, France).

\section{4. $N A S B A$}

Detection of viral pp67 late mRNA and IE1 mRNA in blood leukocytes was done by using NASBA, as described by Blok et al. (1998, 1999). For pp67 mRNA, the NucliSens CMV pp67 assay (Organon Teknika, Boxtel, The Netherlands) was used. Briefly, the assays were performed on a $1 \mathrm{ml}$ aliquot of lysed blood suspension ( $1 \mathrm{ml}$ of whole blood added to $9 \mathrm{ml}$ of NASBA lysis buffer). Nucleic acids were isolated by using the method described by Boom et al. (1990). System control RNA was added to the sample prior to isolation and subsequently served as a positive control for isolation, amplification and detection. Amplification products were detected by electro-chemiluminescence using capture probes coupled to magnetic beads and tris-[2,2-bipyridine]-ruthenium (II) complex-labelled oligonucleotide probes.

\subsection{CMV serology using commercially available} kits

Sera were tested for the presence of $\mathrm{IgG}$ and IgM antibodies against CMV by using two commercially available kits, the AxSYM and IMX CMV assay (Abbott Laboratories, North Carolina, IL). Both tests were based on micro particle enzyme immunoassay techniques. Sera with index values of $\geq 0.600$ for IMX were considered positive. Results from the AxSYM CMV IgG assay were expressed as numbers of antibody units (AU) per ml. Sera with IgG levels of $\geq 15 \mathrm{AU} / \mathrm{ml}$ were considered positive. For seropositive recipients, a 4-fold increase of anti-CMV IgG level compared with the pre-transplantation level was considered significant.

\subsection{Determination of $C M V$ infection}

Active CMV infection was defined by positive results for at least two blood samples in one or 
more of the direct tests used, i.e. viral culture, pp65 antigenemia and viral mRNA detection. CMV infection was further classified as a primary infection or reinfection depending on whether, using the AxSYM CMV IgG assay, the patient was seronegative or seropositive, respectively, before transplantation.

\subsection{The generation of plasmid constructs that express recombinant antigens}

Novel anti-CMV IgM ELISA assays were developed using recombinant fusion proteins, that were expressed in and purified from Escherichia coli. The expression plasmids were generated as follows. The DNA fragment encoding amino acids $98-358$ of the p38 (pUL80a) protein of the Towne strain of human CMV was generated by PCR amplification, using the following primers: 5'-TGAGTGAATTCGCGGACTACGTGGATCCCC-3' (P38-N2-EI) and 5'-AGCTTGAATTCCACCATGTCTTTGGGCGG-3' (P38-C2-EI). To facilitate cloning of the resulting PCR product, Eco RI restriction endonuclease cleavage sites (underlined) were introduced into the DNA primers. The PCR product was purified, digested with $E c o$ RI and cloned into the Eco RI site of vector pRSET $B$ (Invitrogen). In the resulting plasmid, the UL80a gene fragment is present at the $3^{\prime}$ end of, and in-frame with, a fragment encoding six histidines $(6 \mathrm{H})$. Similarly, a DNA fragment encoding amino acids $912-1048$ of the pp150 (ppUL32) protein of HCMV (Towne strain) was generated by PCR. The following oligonucleotides were used: 5'-TGGCAAAGCTTTGGTAGGTCGACCGCCCTC-3' (PP150-N2-HIII) and 5'-TCGTCAAGCTTCCTCCGTGTTCTTAATCTTCTCG-3' (PP150C2-HIII). Both primers contain HindIII restriction endonuclease cleavage sites (underlined). After amplification, the PCR product was purified, cleaved with HindIII and cloned into the HindIII site of vector pRSET B (Invitrogen). In the resulting plasmid, the UL32 gene fragment is present at the $3^{\prime}$-end of, and in-frame with, a fragment encoding $6 \mathrm{H}$. The integrity of the cloned PCR products was verified by DNA sequencing.

\subsection{The expression and purification of recombinant antigens}

E. coli BL21 (DE3) plys S containing the pRSET B-derived expression vectors was grown overnight at $37{ }^{\circ} \mathrm{C}$ in $\mathrm{TB}$ medium (Ausubel et al., 1998) containing ampicillin and chloramphenicol. Subsequently, the cultures were diluted 1:100 in fresh medium and incubated at $37{ }^{\circ} \mathrm{C}$ until the cultures reached an $\mathrm{OD}_{600}$ of 0.8 . Protein expression was induced by the addition of isopropyl- $\beta$-D-thiogalactopyranoside (IPTG) to a final concentration of $0.1 \mathrm{mM}$. After incubation at $37{ }^{\circ} \mathrm{C}$ for $3 \mathrm{~h}$, the bacteria were harvested by low-speed centrifugation. Purification of the $6 \mathrm{H}$-tagged proteins from the bacterial pellet was carried out by one-step affinity chromatography over $\mathrm{Ni}^{2+}$-chelating sepharose (Probond, Invitrogen). The purification was performed under denaturing conditions (in buffers containing $8 \mathrm{M}$ urea), essentially as described by the manufacturers of the column material. After purification, the proteins were renatured by gradual dilution of the urea by dialysis against PBS. The purity of the recombinant proteins was checked by SDS polyacrylamide gelelectrophoresis and staining with Coomassie Brilliant Blue. The proteins were estimated to have a purity of approximately 95\% (data not shown).

\subsection{Recombinant ELISA}

Recombinant ELISA was performed as described by Landini et al. (1995). Briefly, microtiter plates were coated with the CMV proteins in coating buffer (0.01 $\mathrm{M}$ phosphate buffer, $\mathrm{pH}$ 7.2) for $16 \mathrm{~h}$ at $4{ }^{\circ} \mathrm{C}$. The sera were diluted in phosphate buffered saline ( $\mathrm{pH}$ 7.2) (PBS) containing $0.1 \%$ Tween 20. After incubation at $37{ }^{\circ} \mathrm{C}$ for 1 $\mathrm{h}$, the wells were washed and incubated with HRP-conjugated rabbit antibody to human IgM $\mathrm{F}(\mathrm{ab})_{2}$ (DAKO) diluted in PBS containing 1\% BSA for $1 \mathrm{~h}$. The wells were washed, and incubated with $o$-phenylenediamine for $30 \mathrm{~min}$. Subsequently, the colouring reaction was stopped by adding $\mathrm{H}_{2} \mathrm{SO}_{4}$. The absorbance was measured at $620 \mathrm{~nm}$. 
For each sample, the immunoreaction level was measured by using dilutions of 1:20, 1:40, 1:80 and $1: 160$. The cut off values were determined by testing 100 serum samples that did not contain IgM to CMV. The mean absorbance values plus two standard deviations were less than an $\mathrm{OD}_{620}$ of 0.1 . For practical reasons, for each protein the cut off value was set at an $\mathrm{OD}_{620}$ of 0.1 . Reproducibility was controlled by using standard serum samples. In each test run, both positive and negative control samples were included. The runs were considered acceptable when the value of each control sample was within an interval of two S.D.s from the reliable mean value established earlier. To identify potential false-positive results caused by rheumatoid factors, selected sera were retested after treatment with RF absorbent (Behring, Marburg, Germany).

\subsection{Statistical analysis}

Data analysis was carried out using Pierson's $\chi^{2}$-test to compare proportions. Differences with a $P$-value of less than 0.05 were considered to be statistically significant.

\section{Results}

\subsection{Occurrence of $C M V$ infection in renal transplant recipients}

The occurrence of CMV infection in 46 renal transplant recipients was monitored on a regular basis. For the detection of active CMV infection, three types of direct tests were used: virus culture, pp65 antigenemia and viral mRNA detection (by IE1-NASBA and pp67-NASBA). Two commercially available assays were used as reference tests to detect IgM antibody development. The diagnostic value of $\operatorname{IgM}$ antibody detection using these commercially available tests, IMX and AxSYM tests was compared with two newly developed tests: (1) p38 ELISA which was developed using recombinant HCMV p38 protein; and (2) pp150 ELISA which was developed using recombinant HCMV pp150 protein.

In 28 out of the 46 recipients, active CMV infection was diagnosed. In six of the recipients primary CMV infection occurred. As shown in Table 1, all direct assays were positive for these six recipients with IE1-NASBA being the first test to become positive after transplantation (mean day 35; range $18-70)$. The other tests became positive at mean day 40 (range 24-70) for viral culture, day 42 (range 26-70) for pp65 antigenemia, day 43 (range 26-71) for pp67-NASBA, day 47 (range 35-73) for the AxSYM CMV IgM assay and day 49 (range 38-70) for the AxSYM CMV IgG assay. Further analysis of all CMV-infected recipients $(n=28)$ shows that in some of these recipients $(n=16)$ more than one direct test became positive after transplantation, while in others $(n=12)$ the IE1-NASBA was the only positive test. In all 28 recipients, a significant rise in $\mathrm{CMV} \mathrm{IgG}$ was recorded.

Table 1

Results of renal transplant recipients $(n=6)$ with primary CMV infection ${ }^{\mathrm{a}}$ and positive for all direct assays used

\begin{tabular}{|c|c|c|c|c|c|c|}
\hline \multirow[t]{2}{*}{ Patient number } & \multicolumn{6}{|c|}{ Post-transplantation day of first positive result ${ }^{\mathrm{c}}$} \\
\hline & IE1-NASBA & Viral culture & Antigenemia & pp67 NASBA & $\operatorname{IgM}^{b}$ & $\operatorname{IgG}^{b}$ \\
\hline B-2 & 26 & 28 & 28 & 28 & 35 & 39 \\
\hline F-5 & 18 & 26 & 26 & 26 & 39 & 39 \\
\hline S-14 & 21 & 24 & 31 & 35 & 38 & 38 \\
\hline C-21 & 25 & 32 & 35 & 32 & 35 & 46 \\
\hline S-31 & 70 & 70 & 70 & 76 & 73 & 70 \\
\hline B-34 & 59 & 63 & 63 & 63 & 63 & 63 \\
\hline Mean & 35 & 40 & 42 & 43 & 47 & 49 \\
\hline
\end{tabular}

a These patients were seronegative recipients receiving a kidney from a seropositive donor.

${ }^{\mathrm{b}} \mathrm{IgG}$ and IgM antibodies detected by AxSYM.

${ }^{c}$ The day after transplantation of the first positive result is given. 
In order to analyse the IgM response in CMVinfected recipients in more detail, we divided the 46 recipients in three groups on the basis of the results from the direct tests. Group I consisted of 16 recipients positive for IE1-NASBA and at least one other positive direct test. Group II consisted of 12 recipients positive for IE1-NASBA, but negative for all other direct tests used. Group III consisted of 18 recipients in which no direct tests, including viral culture, antigenemia, IE1-NASBA and pp67-NASBA, were found positive. For each group, we compared the results of the direct tests with the results of the IgM antibody tests (indirect tests).

3.2. IgM antibody response in recipients in which more than one direct test became positive (group I)

In 16 recipients, $\mathrm{CMV}$ infection was detected by more than one direct test (Table 2). In all these recipients the IE1-NASBA was positive. A positive result with the other direct tests was less frequently observed, i.e. 12 recipients were positive with pp67-NASBA, 10 with antigenemia, and only one with viral culture. In all 16 recipients, IgM antibodies were detected by both AxSYM and p38 ELISA. With the IMX assay, 13 recipients were found IgM positive, whereas eight out of 16 recipients became positive with the pp150 ELISA. All tests for anti-CMV IgM antibodies remained negative in all 18 group III recipients that did not give positive results in any direct assay used. This indicated that, in this study of renal transplant recipients, in recipients without active CMV infection, anti-CMV IgM antibodies were not produced (specificity for active infection $=100 \%$ ).

We found that in all group I recipients, IE1NASBA was the first test to become positive. The mean first day of positivity of all tests is given in Table 2. For IE1-NASBA, the mean first day of positivity was day 33 (range 18-70). For all other tests, the mean first day of positivity was between day 41 and day 45 after transplantation. Interestingly, in five recipients, IgM antibodies were detected simultaneously with the IE1-NASBA. The early IgM positivity was only observed in seropositive IgG recipients and never in seronegative recipients with a primary CMV infection (Table $1)$.

3.3. IgM antibody response in recipients in which the IE1-NASBA was the only positive direct test (group II)

In 12 recipients, IE1-NASBA was the only direct test to become positive after transplantation. All recipients belonging to this group (group II) were seropositive before transplantation. The mean first day of IE1-NASBA positivity was day 31 (range 11-67). This was similar to the result

Table 2

Detection of CMV infection in 16 renal transplant recipients (group I) positive for IE1-NASBA and at least one other direct test used

\begin{tabular}{|c|c|c|c|c|c|c|c|c|}
\hline \multirow[t]{2}{*}{ Test and results } & \multicolumn{4}{|c|}{ Number of recipients with positive 'direct tests' } & \multicolumn{4}{|c|}{ Number of recipients with positive IgM test } \\
\hline & IE1-NASBA & $\begin{array}{l}\text { pp65 } \\
\text { antigenemia }\end{array}$ & $\begin{array}{l}\text { Viral } \\
\text { Culture }\end{array}$ & pp67-NASBA & p38ELISA & $\begin{array}{l}\text { AxSYM } \\
\text { CMV IgM }\end{array}$ & $\begin{array}{l}\text { IMX CMV } \\
\text { IgM }\end{array}$ & $\begin{array}{l}\text { pp150 } \\
\text { ELISA }\end{array}$ \\
\hline Positive $^{\mathrm{a}}$ & 16 & 9 & 14 & 12 & 16 & 16 & 13 & 8 \\
\hline First positive test ${ }^{\mathrm{b}}$ & 16 & 1 & 1 & 0 & 3 & 5 & 3 & 3 \\
\hline $\begin{array}{l}\text { Day of first positive } \\
\text { test }^{\mathrm{c}} \text { range }\end{array}$ & $\begin{array}{l}33 \\
(18-70)\end{array}$ & $\begin{array}{l}41 \\
(26-70)\end{array}$ & $\begin{array}{l}42 \\
(24-70)\end{array}$ & $\begin{array}{l}43 \\
(26-76)\end{array}$ & $\begin{array}{l}41 \\
(17-87)\end{array}$ & $\begin{array}{l}42 \\
(17-76)\end{array}$ & $\begin{array}{l}43 \\
(35-73)\end{array}$ & $\begin{array}{l}45 \\
(33-87)\end{array}$ \\
\hline
\end{tabular}

${ }^{a}$ Number of recipients in which the test became positive after transplantation.

${ }^{\mathrm{b}}$ Number of recipients in which the test was the first positive test.

${ }^{\mathrm{c}}$ The day (mean) at which the first positive signal was detected. 
Table 3

Anti-CMV IgM antibody detection in renal transplant recipients $(n=12)$ positive for IE1-NASBA (group II) and negative for pp65-antigenemia, viral culture and pp67-NASBA

\begin{tabular}{|c|c|c|c|c|c|}
\hline & \multicolumn{5}{|l|}{ IgM test } \\
\hline & $\begin{array}{l}\text { AxSYM CMV } \\
\text { IgM }\end{array}$ & IMX CMV IgM & pp150 ELISA & p38 ELISA & $\begin{array}{l}\text { Number of recipients } \\
\text { positive for this } \\
\text { combination }\end{array}$ \\
\hline \multirow{5}{*}{$\begin{array}{l}\text { Combination of } \\
\text { positive/negative tests in } \\
\text { group II }\end{array}$} & + & + & + & + & 1 \\
\hline & + & + & + & - & 8 \\
\hline & + & + & - & - & 1 \\
\hline & + & - & + & + & 1 \\
\hline & + & - & - & - & 1 \\
\hline $\begin{array}{l}\text { Number of recipients } \\
\text { positive for this test }\end{array}$ & 12 & 10 & 10 & 2 & \\
\hline
\end{tabular}

from group I. As the detection of IE1 mRNA in blood in the absence of any other positive direct test is a rather unexplained phenomenon, we were interested to determine whether these recipients had developed a humoral response against CMV antigens. Indeed, a significantly increased $\operatorname{IgG}$ response could be detected in all group I and group II recipients. In addition, it was possible to detect IgM antibody responses in each of the group II recipients by using the AxSYM CMV IgM assay (Table 3). With both the IMX and the pp150 ELISA, we detected a rise in the level of IgM antibodies in the majority (10 out of 12) of the recipients. Interestingly, only two recipients were found positive with the $\mathrm{p} 38$ ELISA. This result contrasts with the finding of anti-CMV IgM antibodies in $100 \%$ of the group I recipients by this assay.

\section{Discussion}

We have monitored the anti-CMV IgM response in a group of 46 renal transplant recipients by using two commercially available IgM kits as well as two novel ELISAs based on pp150 (ppUL32) and p38 (pUL80a), which were shown to be immunodominant markers for the anti-CMV IgM response by earlier immunoblot studies (Kraat et al., 1996). The results from these assays were compared with those from four different direct CMV diagnostic tests: (1) pp65 antigenemia; (2) viral culture; (3) IE1 NASBA; and (4) pp67 NASBA. With the direct tests, positive results were obtained in $28(61 \%)$ of 46 recipients. Earlier studies in renal transplant recipients showed similar percentages of positive direct CMV tests (between 64 and 73\%), while in liver transplant recipients higher percentages were reported (Goossens et al., 1999). In this study of 46 renal transplant recipients, all $28 \mathrm{CMV}$-infected recipients were IE1-NASBA positive, whereas lower percentages of positivity were obtained with other tests (viral culture: $50 \%$; pp67-NASBA: $43 \%$; antigenemia: $32 \%$ ). Similar results were obtained in earlier studies in renal transplant recipients (Goossens et al., 2000) and in bone marrow transplant recipients (Gerna et al., 2000) in which the sensitivity of IE1-NASBA was higher than that of PCR and other direct tests.

The results obtained by the direct tests were compared with those from the IgM assays. In the present study, we used ELISA with purified recombinant $\mathrm{p} 38$ and pp150 and detected IgM antibodies in 28 out of 46 recipients (61\%). In all recipients with confirmed active CMV infection (as defined by a repeated positive result in one or more direct tests), IgM antibodies were detected. IgM antibodies were not detected in recipients with negative direct tests. These results confirm the specificity of the anti-CMV IgM assays and are in agreement with data of Greijer et al. (1999), Landini (1993) and earlier work from our own laboratory (Kraat et al., 1996). 
In this study, comparison of the IgM immune response against $\mathrm{p} 38$ and pp150 showed that the response differs significantly $(P$-value $<0.01)$ between group I recipients, which suffer from a productive CMV infection, and group II recipients, which only show the production of IE1 CMV mRNA in the absence of viral replication. In the first group, IgM antibodies against p38 were detected in all recipients, while only $50 \%$ of these recipients had antibodies against pp150. In contrast, in the recipients of group II, more IgM antibodies were detected against pp150 $(83 \%)$ than against p38 $(17 \%)$. Although, a productive infection was seen in group I recipients, as inferred from the presence of infectious virus and the expression of late CMV mRNA, it is likely that in group II recipients, an abortive CMV infection occurred, as reflected by the restricted expression of IE1 CMV mRNA only. In this way, the expression of viral mRNAs is correlated with the presence of anti-p38 and antipp150 IgM-antibodies. Expression of late viral mRNAs is correlated with a higher frequency of anti-p38 IgM antibodies compared with antipp150 IgM antibodies. In recipients with only expression of IE1 mRNA, there is a higher frequency of anti-pp150 IgM antibodies compared with anti-p38 $\operatorname{IgM}$ antibodies. The precise nature of the correlation is not yet clear. However, earlier studies have indicated that latent CMV carriers frequently have (high levels of) antipp150 antibodies, suggestive of high levels of Bcell memory for pp150. This may correlate with rapid induction of pp150 specific IgM upon virus reactivation (Greijer et al., 1999; Kraat et al., 1996).

Taken together, our data suggest that individual recipients develop antibody responses to different CMV antigens, which indicates the importance of using mixtures of viral antigens for IgM antibody detection. The combination of pp150 and p38 was found to be a useful combination to detect IgM antibodies in patients suffering from an active CMV infection. In addition, monitoring the $\operatorname{IgM}$ response to $\mathrm{p} 38$ and pp150 may be of value for diagnosis and prognosis of CMV infected transplant recipients.

\section{Acknowledgements}

The authors thank Professor Dr J. van Hooff, Dr M.H.L. Christiaans and colleagues of the Department of Internal Medicine, University Hospital Maastricht for the provision of clinical material, P. Sillekens (Organon Teknika) and M.J. Blok for their helpful discussions, and S.J.V. Vanherle for her outstanding technical assistance.

\section{References}

Ausubel FM, Brent R, Kingston RE, Moore DD, Seidman JG, Smith JA, Struhl K. Current Protocols in Molecular Biology, vol. 1. New York: Wiley, 1998.

Basson J, Tardy JC, Aymard M. Pattern of anti-cytomegalovirus IgM antibodies determined by immunoblotting. A study of kidney graft recipients developing a primary or recurrent CMV infection. Arch Virol 1989;108:259-70.

Blok MJ, Goossens VJ, Vanherle SJV, Top B, Tacken N, Middeldorp JM, Christiaans MH, Van Hooff J, Bruggeman CA. Diagnostic value of monitoring human cytomegalovirus late pp67 mRNA expression in renal-allograft recipients by nucleic acid sequence-based amplification. J Clin Microbiol 1998;36:1341-6.

Blok MJ, Christiaans MHL, Goossens VJ, van Hooff JP Sillekens P, Middeldorp JM, Bruggeman CA. Early detection of cytomegalovirus infection after kidney transplantation by nucleic acid sequence-based amplification. Transplantation 1999;67:1274-7.

Boom R, Sol CJA, Salimans MMM, Jansen CL, Wertheim-van Dillen PME, Van der Noordaa J. Rapid and simple method for purification of nucleic acids. $\mathrm{J}$ Clin Microbiol 1990;28:495-503.

Cope AV, Sabin C, Burroughs A, Rolles K, Griffiths PD, Emery VC. Interrelationships among quantity of human cytomegalovirus (HCMV) DNA in blood, donor-recipient serostatus, and administration of methylprednisolone as risk factors for HCMV disease following liver transplantations. J Infect Dis 1997;176:1484-90.

Erice A, Jordan MC, Chace BA, Fletcher C, Chinnock BJ, Balfour HH Jr. Ganciclovir treatment of cytomegalovirus disease in transplant recipients and other immunocompromised hosts. J Am Assoc 1987;257:3082-7.

Fox JC, Griffiths PD, Emery VC. Quantification of human cytomegalovirus DNA using the polymerase chain reaction. J Gen Virol 1992;73:2405-8.

Gerna G, Zipeto D, Parea M, Revello MG, Silini E, Percivalle E, Zavattoni M, Grossi P, Milanesi G. Monitoring of human cytomegalovirus infections and ganciclovir treatment in heart transplant recipients by determination of viremia, antigenemia, and DNAemia. J Infect Dis 1991;164:488-98. 
Gerna G, Baldanti F, Middeldorp JM, Furione M, Zavattoni M, Lilleri D, Revello MG. Clinical significance of expression of human cytomegalovirus pp67 late transcript in heart, lung, and bone marrow transplant recipients as determined by nucleic acid sequence-based amplification. J Clin Microbiol 1999;37:902-11.

Gerna G, Baldanti F, Lilleri D, Parea M, Alessandrino E, Pagani A, Locatelli F, Middeldorp J, Revello MG. Human cytomegalovirus immediate-early mRNA detection by nucleic acid sequence-based amplification as a new parameter for preemptive therapy in bone marrow transplant recipients. J Clin Microbiol 2000;38:1845-53.

Gleaves CA, Reed EC, Hackman RC, Meyers JD. Rapid diagnosis of invasive cytomegalovirus infection by examination of tissue specimens in centrifugation culture. Am $\mathbf{J}$ Clin Pathol 1987;88:354-8.

Goossens VJ, Blok MJ, Christiaans MH, van Hooff JP, Sillekens P, Höckerstedt K, Lautenschlager I, Middeldorp JM, Bruggeman CA. Diagnostic value of nucleic-acid-sequence-based amplification for the detection of cytomegalovirus infection in renal and liver transplant recipients. Intervirology 1999;42:373-81.

Goossens VJ, Blok MJ, Christiaans MHL, Sillekens P, Middeldorp JM, Bruggeman CA. Early detection of cytomegalovirus in renal transplant recipients: comparison of PCR, NASBA, pp65-antigenemia and viral culture. Transplant Proc 2000;32:155-8.

Greijer AE, van de Crommert JMG, Stevens SJC, Middeldorp JM. Molecular fine-specificity analysis of antibody responses to human cytomegalovirus and design of novel synthetic-peptide-based serodiagnostic assays. J Clin Microbiol 1999;37:179-88.

Knox KK, Drobyski WR, Carrigan DR. Cytomegalovirus isolate resistant to ganciclovir and foscarnet from a marrow transplant recipient. Lancet 1991;337:1292-3.

Kraat YJ, Stals FS, Landini MP, Bruggeman CA. Cytomegalovirus IgM antibody detection: comparison of five assays. Microbiologica 1993;16:297-307.

Kraat YJ, Christiaans MH, Nieman FH, van den BergLoonen PM, van Hooff JP, Bruggeman CA. Risk factors for cytomegalovirus infection and disease in renal transplant recipients: HLA-DR7 and triple therapy. Transplant Int 1994;7:362-7.

Kraat YJ, Stals FS, Christiaans MH, Lazzarotto T, Landini MP, Bruggeman CA. IgM antibody detection of ppUL80A and ppUL32 by immunoblotting: an early parameter for recurrent cytomegalovirus infection in renal transplant recipients. J Med Virol 1996;48:289-94.

Landini MP. New approaches and perspectives in cy- tomegalovirus diagnosis. Prog Med Virol 1993;40:157-77.

Landini MP, Lazzarotto T, Maine G, Ripalti A, Flanders R. Recombinant mono- and polyantigens to detect cytomegalovirus-specific immunoglobulin $\mathrm{M}$ in human sera by enzyme immunoassay. J Clin Microbiol 1995;33:253542.

Lazzarotto T, Ripalti A, Bergamini G, Battista MC, Spezzacatena P, Campanini F, Pradelli P, Varani S, Gabrielli L, Maine GT, Landini MP. Development of a new cytomegalovirus (CMV) immunoglobulin $\mathrm{M}$ (IgM) immunoblot for detection of CMV-specific IgM. J Clin Microbiol 1998:36:3337-41.

Middeldorp JM, Sillekens P, Lunenberg J. Diagnosis of active HCMV infection: the mRNA approach. Organs Tissues 2000;2:99-107.

Nielsen SL, Sorensen I, Andersen HK. Kinetics of specific immunoglobulins $\mathrm{M}, \mathrm{E}, \mathrm{A}$, and $\mathrm{G}$ in congenital, primary, and secondary cytomegalovirus infection studied by antibody-capture enzyme-linked immunosorbent assay. J Clin Microbiol 1988;26:654-61.

Oldenburg N, Lam KMC, Khan MA, Top B, Tacken NMM, McKie A, Mikhail GW, Middeldorp JM, Wright A, Banner NR, Yacoub M. Evaluation of human cytomegalovirus gene expression in thoracic organ transplant recipients using nucleic acid sequence-based amplification. Transplantation 2000;70:1209-15.

Schoppel K, Schmidt C, Einsele H, Hebart H, Mach M. Kinetics of the antibody response against human cytomegalovirus-specific proteins in allogeneic bone marrow transplant recipients. J Infect Dis 1998;178:1233-43.

The TH, van der Bij W, van den Berg AP, van der Giessen M, Weits J, Sprenger HG, van Son WJ. Cytomegalovirus antigenemia. Rev Infect Dis (Suppl 7) 1990;12:S734-44.

Van der Bij W, Schirm J, Torensma R, Van Son WJ, Tegzess $\mathrm{AM}$, The TH. Comparison between viremia and antigenemia for detection of cytomegalovirus in blood. J Clin Microbiol 1988;26:2531-5.

Vivarelli M, De Ruvo N, Lazzarotto T, Bellusci R, Landini MP, Varani S, Cavallari A. Abstension from treatment of low-level pp65 cytomegalovirus antigenemia after liver transplantation: a prospective study. Transplantation 2000;70:1183-7.

Zipeto D, Revello MG, Silini E, Parea M, Percivalle E, Zavattoni M, Milanesi G, Gerna G. Development and clinical significance of a diagnostic assay based on the polymerase chain reaction for detection of human cytomegalovirus DNA in blood samples from immunocompromised patients. J Clin Microbiol 1992;30:527-30. 
Chapter 5

\title{
ONSET AND DURATION OF CYTOMEGALOVIRUS IMMEDIATE EARLY 1 mRNA EXPRESSION IN BLOOD OF RENAL TRANSPLANT RECIPIENTS
}

\author{
Valère J. Goossens ${ }^{1}$, Maarten H.L. Christiaans ${ }^{2}$, Marinus J. Blok ${ }^{1}$, Peter H.W. Terporten ${ }^{1}$, \\ Peter Sillekens $^{3}$, Angela Lukacsi ${ }^{4}$, Johannes P. van Hooff ${ }^{2}$, Cathrien A. Bruggeman ${ }^{1}$ \\ ${ }^{1}$ Department of Medical Microbiology, University Hospital Maastricht \\ ${ }^{2}$ Department of Internal Medicine, University Hospital Maastricht \\ ${ }^{3}$ Department of Molecular Diagnostics, BioMérieux, Boxtel, The Netherlands \\ ${ }^{4}$ Department of Medical Microbiology and Immunology, University of Szeged, Hungary
}

Journal of Medical Virology

Accepted for publication 



\begin{abstract}
Human cytomegalovirus (CMV) messenger (m) RNA expression in circulating leukocytes directly reflects viral activity in the human host. In this study, sixty-nine patients were prospectively monitored for CMV infection and mRNA expression during the first year after renal transplantation. Of these 69 recipients, 58 (84\%) recipients were positive for CMV immediate early 1 (IE1) mRNA as detected by NASBA. The median onset of IE1 expression started at day 22 after transplantation and continued for a median duration of 82 days. IE1 mRNA expression started significantly earlier in recipients that developed an active CMV infection $(\mathrm{p}=0.001)$ and in mycophenolate mofetil (MMF) treated recipients $(\mathrm{p}=0.002)$. The duration of IE $1 \mathrm{mRNA}$ expression was significantly longer in recipients that previously had an early onset of IE1 mRNA expression $(\mathrm{p}=0.001)$ and in recipients with an active CMV infection $(p=0.007)$. Remarkably, longer prednisolone intake was correlated with a significantly $(p=0.02)$ shorter duration of IE1 expression compared to a longer duration of IE1 expression in recipients with only a short prednisolone intake. In recipients infected with glycoprotein $\mathrm{B}(\mathrm{gB})$ type $1 \mathrm{CMV}$ strains, the duration of IE1 expression was significantly $(\mathrm{p}=0.04)$ shorter compared to recipients infected with non-gB type 1 CMV strains (64 versus 150 days). Our study indicates that multiple factors play a role in the onset and/or duration of CMV IE1 mRNA expression, e.g. MMF treatment, prednisolone intake and gB type of the specific CMV strain. The clinical significance of these correlations remains to be studied in more detail.
\end{abstract}

\title{
Introduction
}

Previously, we described that cytomegalovirus (CMV) immediate early (IE) 1 mRNA detection by nucleic-acid sequence based amplification (NASBA) is a very sensitive diagnostic method for the early detection of human CMV infection in renal and liver transplant recipients [Blok et al., 1999; Goossens et al., 1999]. Especially for renal transplant recipients, it was demonstrated that the first positive results for CMV were found with IE1 NASBA mostly during the first month posttransplantation and that IE1 NASBA was already positive while all other CMV diagnostic tests were still negative. Thereafter, mostly during the second month posttransplantation, other CMV diagnostic tests, including antigenemia, viral culture and pp67 NASBA, became positive for several days to several weeks while IE1 NASBA was also positive. Finally, after antigenemia, viral culture and pp67 NASBA had returned to negative, IE1 NASBA remained positive for an additional period. However, it was not clear for how long IE1 NASBA was positive nor were external factors identified that correlated with the appearance and/or disappearance of IE1 expression.

Otherwise, there is increasing evidence that IE1 expression and the presence of immediate early and/or early gene products is a key factor in some aspects of the pathogenesis of CMV infection [Cinatl; 1999]. CMV infections cause major complications in organ transplant recipients, and a variety of clinical manifestations of CMV infection such as fever, leukopenia, thrombopenia, encephalitis, retinitis, pneumoniae, hepatitis and glomerulopathy have been described [Rubin; 1990]. In kidney allografts, expression of the CMV genome has been described during active and latent CMV infection and was correlated with tubular, glomerular and interstitial changes [Holma; 2000]. In part, these complications and findings are not explained by productive viral replication with synthesis of new viral DNA and late gene products. More important is the activity of the immediate early and/or early gene products inducing many pro-inflammatory activities with induction of cytokines, chemokines and up regulation of adhesion molecules [Grundy; 1998]. Also immune escape phenomenons are already present in the immediate early/early phase [Miller and Sedmak; 1998]. With increasing prophylactic and therapeutic use of DNApolymerase blocking antiviral products, IE1 and other immediate early/early gene products can still be synthesized and 'build up', whereas viral DNA synthesis is blocked [Grundy; 1998]. For a better understanding of the pathogenesis of CMV infection, more insight in IE1 mRNA expression is necessary.

In this study we investigated the possible correlation between the onset and duration of IE1 mRNA expression and a number of patients characteristics, including age and immunosuppressive therapy. In addition, the expression of IE1 mRNA in different CMV glycoprotein B $(\mathrm{gB})$ genotypes is considered. 


\section{Materials and Methods}

\section{Patients}

In the University Hospital Maastricht, 80 consecutive kidney transplant patients were investigated prospectively during the first twelve months post operation or until nephrectomy or death if this occurred within the first year following transplantation. Follow-up and sampling was done twice a week during hospital stay (mostly three to five weeks) after transplantation. After this period, specimens were collected at least monthly. All specimens were screened prospectively for the presence of CMV by viral culture, antigenemia, IE1 and pp67 NASBA. Eleven patients were excluded from this study since, mostly due to early nephrectomy or exitus, only low numbers of samples were available. The remaining 69 recipients, with a total of 1447 samples (ranging from 10 to 55 samples per patient) were available for analysis.

Maintenance of immunosuppression consisted of treatment with tacrolimus together with prednisolone. Dosing and monitoring of tacrolimus were as described earlier [van Hooff et al., 1999]. Prednisolone treatment was started initially with a steroid bolus of 125 to $250 \mathrm{mg}$ prednisolone around surgery followed by prednisolone $10 \mathrm{mg} /$ day for at least one week. Thereafter, but at different time points, the daily prednisolone intake was gradually decreased or stopped. In retransplant and/or hyperimmunized recipients and in recipients with rejection, mycophenolate mofetil (MMF) was added and recipients were maintained on a triple immunosuppressive drug regimen. If a patient showed signs of CMV disease, ganciclovir was given i.v. for at least 2 weeks until two subsequent blood samples were negative for the antigenemia assay. The perioperative protocol did not include routinely prophylactic anti-CMV therapy. However, patients with a primary $\mathrm{CMV}$ infection $(\mathrm{D}+, \mathrm{R}-)$ also received ganciclovir during rejection therapy with antithymocyte globulin, even in the absence of clinical signs of CMV disease. In addition, patients with positive antigenemia assay results during rejection also received ganciclovir.

\section{NASBA for CMV IE1 mRNA and pp67 mRNA}

In general, isolation, amplification and detection of CMV IE1 mRNA transcripts was done as described previously for pp67 mRNA [Blok et al., 1998]. For amplification, two primers directed to exon 4 of the major immediate early gene were used. Also, a specific IE1 NASBA system control RNA and corresponding probes were used [Blok et al., 1999]. Interpretation of the emitted signals of wild type and system control compared to the cut-off was similar for pp67 and IE1. Results were only accepted as valid if the sum of the wild type signal and the system control signal was at least 10000.

\section{Viral culture and pp65-antigenemia assay}

Both CMV assays were done as described previously by Kraat et al. [1994]. For the detection of infectious CMV in blood, both conventional cell culture with detection of cytopathic effect and shell vial culture with detection of early antigen fluorescent foci were undertaken. For the pp65-antigenemia assay, leukocytes were isolated from whole EDTA blood using dextran and centrifuged onto a glass slide within $4 \mathrm{~h}$ after collection. The cells were fixed subsequently for 10 minutes in $0.37 \%$ formaldehyde and incubated with anti-pp65 mouse monoclonal antibodies. After incubation with horseradish peroxidasecoupled rabbit antimouse IgG (Dako A/S, Glostrup, Denmark), the substrate 3-amino-9-ethylcarbazole was added to stain the pp65-positive cells. Finally, the slides were examined microscopically and the results expressed as the number of positive cells per 50,000 leukocytes [Van der Bij et al., 1988].

\section{gB typing}

Genotyping of CMV strains, isolated by conventional cell culture with detection of CPE, was done on the basis of sequence variation of the $\mathrm{gB}$ gene. This was done by polymerase chain reaction amplification and restriction fragment length polymorphism analysis as described by Lukacsi et al. [2001]. Primers for the 
amplification were selected from the gB sequences of HCMV strain AD169. Amplification products were subjected to restriction analysis by using Hinf I and $R s a$ I. Four different $\mathrm{gB}$ genotypes can be distinguished by different lenght of restriction fragments. In patients positive for shell vial culture but negative for conventional cell culture, no CMV strain was available for $\mathrm{gB}$ typing.

\section{Statistical Analysis}

For statistical analysis, SPSS version 10.0 for Windows (SPSS Inc., Chicago, Il) was used. Two-tailed bivariate analysis was performed using Mann-Whitney U test or Pearson correlation coefficient. Multivariate analysis was performed using backward stepwise Cox regression analysis on all parameters indicated in table 1 (except number of positive tests). Unless indicated otherwise data are given as median values. A p-value $\leq 0.05$ was considered statistically significant. P-values in the range $0.06-0.15$ were considered borderline.

\section{Results}

Sixty-nine renal transplant recipients were investigated prospectively for CMV infection by screening 1447 samples using viral culture, antigenemia, IE1 and pp67 NASBA. For viral culture, detection of early antigen fluorescent foci and cytopathic effect results were combined to give one outcome as described previously [Goossens et al., 1999]. Of these 69 patients, 11 patients were negative for CMV in all tests used while for 58 patients positive results were obtained for at least one of the tests. IE1 NASBA was positive in $58(84 \%)$ of these 69 patients, whereas for viral culture, antigenemia and pp67 NASBA 24 $(35 \%), 21(30 \%)$ and $22(32 \%)$ patients were positive, respectively. For each test, the day of sampling of the first positive blood sample, was defined as the day of onset. The day that the last positive blood sample of a patient was sampled, was defined as the day of disappearance. For each test, the duration (of positivity) was determined as the period between the day of onset and the day of disappearence.

In 15 patients, all four tests used for CMV detection became positive within 12 months post transplantation. As described previously [Goossens et al., 2000], IE1 NASBA was the first positive test with a median onset of positivity at day 21 post transplantation. All other tests became positive at a later median time point, i.e. 27, 33 and 40 days post transplantation for viral culture, antigenemia and pp67 NASBA respectively. The duration of the positivity of all tests was calculated. For the 15 patients that were positive for all four tests, the median duration of positivity was the longest for IE1-NASBA (75 days). All other tests were positive during a shorter period of time, i.e. 15, 29 and 19 days for viral culture, antigenemia and pp67 NASBA, respectively. All positive results for viral culture, antigenemia and pp67 NASBA were obtained within the period of IE1 NASBA positivity. In most patients, after viral culture, antigenemia and/or pp67 NASBA had returned to negative, the IE1 NASBA remained positive for an additional period of several weeks to several months.

To study the factors playing a role in the IE1 mRNA expression, we analyzed further the onset and duration of IE1 mRNA expression in 43 patients, with at least two IE1 NASBA positive samples. In these patients, the median onset of IE1 mRNA expression was at day 22 after transplantation and the median duration was 82 days. The interquartile range for the onset of IE1 mRNA expression was at day 15-36 after transplantation. The interquartile ranges for the duration of IE1 mRNA expression was 51-122 days. Differences in the median onset of IE1 mRNA expression were found in several subgroups of patients (table 1). Using multivariate analysis, the onset of IE1 mRNA expression was found to correlate with antigenemia positivity $(\mathrm{p}=0.001)$ and viral culture positivity $(\mathrm{p}=0.05)$. Eleven patients were treated with MMF in the posttransplant period. In this group of 11 patients, the median onset of IE1 mRNA expression was at day 16 whereas in patients without MMF treatment this was day 25 (table 1 ). This proved to be a statistically significant difference ( $\mathrm{p}=0.002)$ (fig. 1 ). In the MMF treated patients the median duration of IE1 expression was 95 days, whereas this was 75 days in the patients without MMF treatment. However, this difference was not statistically significant. For ten patients treated with ganciclovir, the median onset of IE1 mRNA expression was at day 21, compared to day 22 for 33 patients without ganciclovir 
treatment. The duration of IE1 mRNA expression in patients with or without ganciclovir treatment was 91 and 82 days respectively. These differences were not statistically significant.

Table 1. Median day of onset and duration of IE 1 mRNA expression in renal transplant recipients ${ }^{1}$

\begin{tabular}{|c|c|c|c|}
\hline Subgroups & $\begin{array}{c}\text { Number of } \\
\text { patients }\end{array}$ & $\begin{array}{c}\text { Median day of } \\
\text { onset }\end{array}$ & $\begin{array}{c}\text { Median day of } \\
\text { duration }\end{array}$ \\
\hline Gender of recipient: males / females & $26 / 17$ & $23 / 22$ & $84 / 75$ \\
\hline Age of recipient: $<60 / \geq 60$ years $^{2}$ & $30 / 13$ & $23 / 22$ & $79 / 106$ \\
\hline CMV serostatus of donor: positive / negative & $25 / 18$ & $22 / 22$ & $74 / 85$ \\
\hline $\begin{array}{l}\text { CMV serostatus of recipient: positive / } \\
\text { negative }\end{array}$ & $23 / 20$ & $22 / 23$ & $74 / 101$ \\
\hline Viral culture positive / negative & $23 / 20$ & $22 / 23$ & $96 / 78$ \\
\hline Antigenemia positive / negative & $21 / 22$ & $21 / 23$ & $106 / 73$ \\
\hline Pp67 NASBA positive / negative & $20 / 23$ & $21 / 22$ & $91 / 74$ \\
\hline Number of positive tests ${ }^{3}: \geq 3 / \leq 2$ & $20 / 23$ & $21 / 22$ & $108 / 71$ \\
\hline $\begin{array}{l}\text { Onset of IE } 1 \text { mRNA expression at post } \\
\text { transplantation day : } \\
-\quad \text { Between day } 1-16 \\
-\quad \text { Between day } 17-28 \\
-\quad \text { Between day } 30-198 \\
\end{array}$ & $\begin{array}{l}14 \\
15 \\
14\end{array}$ & & $\begin{array}{l}91 \\
75 \\
66\end{array}$ \\
\hline Use / no use of mycophenolate mofetil & $11 / 32$ & $16 / 25$ & $95 / 75$ \\
\hline Use / no use of ganciclovir & $10 / 33$ & $21 / 22$ & $91 / 82$ \\
\hline $\begin{array}{l}\text { Decrease of prednisolone intake to }<10 \\
\text { mg/day at posttransplantation day : } \\
-\quad \text { Between day } 6-21 \\
-\quad \text { Between day } 22-34 \\
-\quad \text { Between day } 35-219\end{array}$ & $\begin{array}{l}13 \\
17 \\
13\end{array}$ & $\begin{array}{l}17 \\
24 \\
22\end{array}$ & $\begin{array}{l}85 \\
74 \\
75\end{array}$ \\
\hline $\begin{array}{ll}\text { Prednisolone stop at posttransplantation day: } \\
\text { - } & \text { Between day } 6-56 \\
- & \text { Between day } 57-134 \\
- & \text { Between day } 144->366\end{array}$ & $\begin{array}{l}13 \\
13 \\
13 \\
\end{array}$ & $\begin{array}{l}21 \\
22 \\
25\end{array}$ & $\begin{array}{l}85 \\
74 \\
64 \\
\end{array}$ \\
\hline $\begin{array}{l}\text { Isolated CMV strains }{ }^{4}: \\
-\quad \text { gB type } 1 \\
-\quad \text { Non gB type } 1\end{array}$ & $\begin{array}{l}9 \\
8\end{array}$ & $\begin{array}{l}25 \\
18\end{array}$ & $\begin{array}{c}64 \\
150 \\
\end{array}$ \\
\hline \multicolumn{4}{|c|}{$\begin{array}{l}{ }^{1} \text { In this analysis } 43 \text { renal transplant recipients }(15 x D+R-, 10 \times D+R+, 13 x D-R+, 5 \times D-R-) \\
\text { least two samples positive for IE1 NASBA were included. } \\
{ }^{2} \text { This group included also the } 3 \text { patients with longest duration of IE } 1 \mathrm{mRNA} \text { expression. } \\
3 \text { Tests included were viral culture, antigenemia, pp } 67 \text { NASBA and IE } 1 \text { NASBA. } \\
{ }^{4} \text { Isolation of CMV in blood by conventional cell culture with detection of cvtopathic effect. }\end{array}$} \\
\hline
\end{tabular}

Since we were interested in the correlation between the different CMV detection tests used in this study, we also analyzed the correlation between duration of IE1 mRNA positivity and viral culture, antigenemia and/or pp67 NASBA. As shown in table 1, the median duration of IE1 mRNA expression was higher, namely 96, 106 and 91 days respectively when viral culture, antigenemia and pp67 NASBA were positive, compared to 78,73 and 74 days for patients negative for these tests. Similarly, the median duration of IE1 mRNA expression was higher in patients with 3 or 4 positive tests, namely 108 days, whereas this was 71 days in patients positive for only 1 or 2 tests. Using bivariate analysis (data not shown), these differences were statistically significant for the number of positive tests $(p=0.02)$, antigenemia positivity $(\mathrm{p}=0.03)$ and borderline significant for pp67 NASBA positivity $(\mathrm{p}=0.13)$ and for viral culture positivity $(\mathrm{p}=0.15)$. Using multivariate analysis a highly significant $(\mathrm{p}=0.007)$ correlation between the duration of IE1 mRNA expression and viral culture was confirmed (fig. 2). 
The duration of IE1 mRNA expression was also correlated with the time of onset of IE1 mRNA expression. After dividing the patients into three similar sized groups, IE1 mRNA could be detected during a median period of 91,75 and 66 days in patients in whom the onset of IE1 mRNA expression occurred between 1-16, 17-28 and 30-198 days posttransplantation, respectively (table 1). Using multivariate analysis, this inverse correlation between duration and time of onset of IE1 mRNA expression proved to be highly significant $(\mathrm{p}=0.001)$.

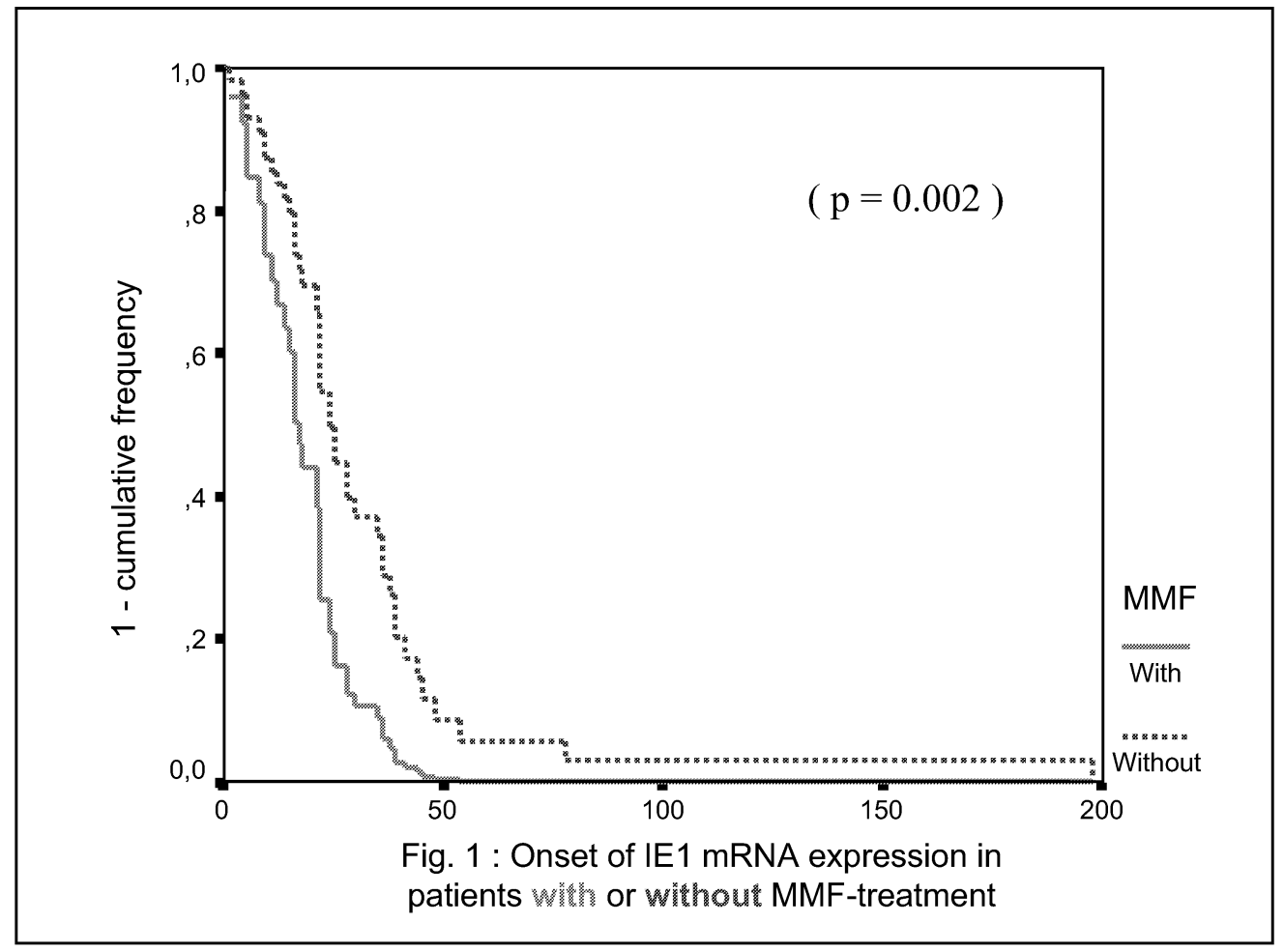

Fig. 1. Multivariate analysis of the significant $(p=0.002)$ correlation between the use of mycophenolate mofetil (MMF) and the onset of immediate early $1 \mathrm{mRNA}$ expression. The X-axis indicates the post transplantation day of the first positive IEI NASBA result.

For 30 patients at the age of 15 to 59 years, the median duration of IE1 mRNA expression was 79 days, compared to 106 days for 13 older patients at the age of 60-75 years (table 1). Within the latter group, also the three patients with longest duration of IE1 mRNA expression, e.g. 239, 257 and 264 days, were included.

All 43 patients were treated with prednisolone. In the first period after transplantation, patients received a daily prednisolone dosis of $10 \mathrm{mg} /$ day. Thereafter, the daily prednisolone intake was gradually decreased. The median day at which the daily prednisolone intake decreased to less than 10 or $5 \mathrm{mg} / \mathrm{day}$ was respectively at day 30 and day 81 after transplantation. The median day at which prednisolone was no longer administered to the patient was at day 100 after transplantation. If therapy with prednisolone was stopped before day 57, the median duration of IE1 mRNA expression was 85 days compared to 64 days in patients for whom therapy was stopped after day 134 (table 1). Multivariate analysis confirmed the association between the moment of prednisolone stop $(\mathrm{p}=0.04)$ and the duration of IE $1 \mathrm{mRNA}$ positivity. A similar result was obtained between the moment of prednisolone decrease below $10 \mathrm{mg} / \mathrm{day}(\mathrm{p}=0.02)$ and the duration of IE1 mRNA expression. Remarkably, the correlation found between prednisolone intake and duration of IE1 mRNA expression was inverse indicating that prolonged intake of prednisolone was associated with a shorter duration of IE1 mRNA expression.

Differences in onset and duration of IE1 mRNA expression were also found in patients infected with CMV strains with different $\mathrm{gB}$ types. In 9 of 17 patients in whom CMV was isolated from blood cells, gB 
type 1 was detected. In these patients, the median duration of IE1 mRNA expression was only 64 days compared to 150 days in 8 patients infected with a non-gB type $1 \mathrm{CMV}$ strain $(3 \mathrm{x}$ gB $2,3 \mathrm{x}$ gB 3 and $2 \mathrm{x}$ $\mathrm{gB} 4$ ) (table 1). The correlation between an infection with a CMV gB type 1 strain and a shorter duration of IE1 mRNA expression was significant ( $\mathrm{p}=0.04$ ). In the subgroup of patients infected with CMV strains of gB type 1, the median onset of IE1 mRNA expression was at day 25 compared to a median onset at day 18 for patients infected with non gB type 1 CMV strains. However, this difference in onset was not statistically significant. Similarly, in patients infected with gB type 1 CMV strains, no significant differences were found in the number of positive tests (table 1) and the maximal antigenemia levels (data not shown) compared to patients infected with non-gB type 1 CMV strains.

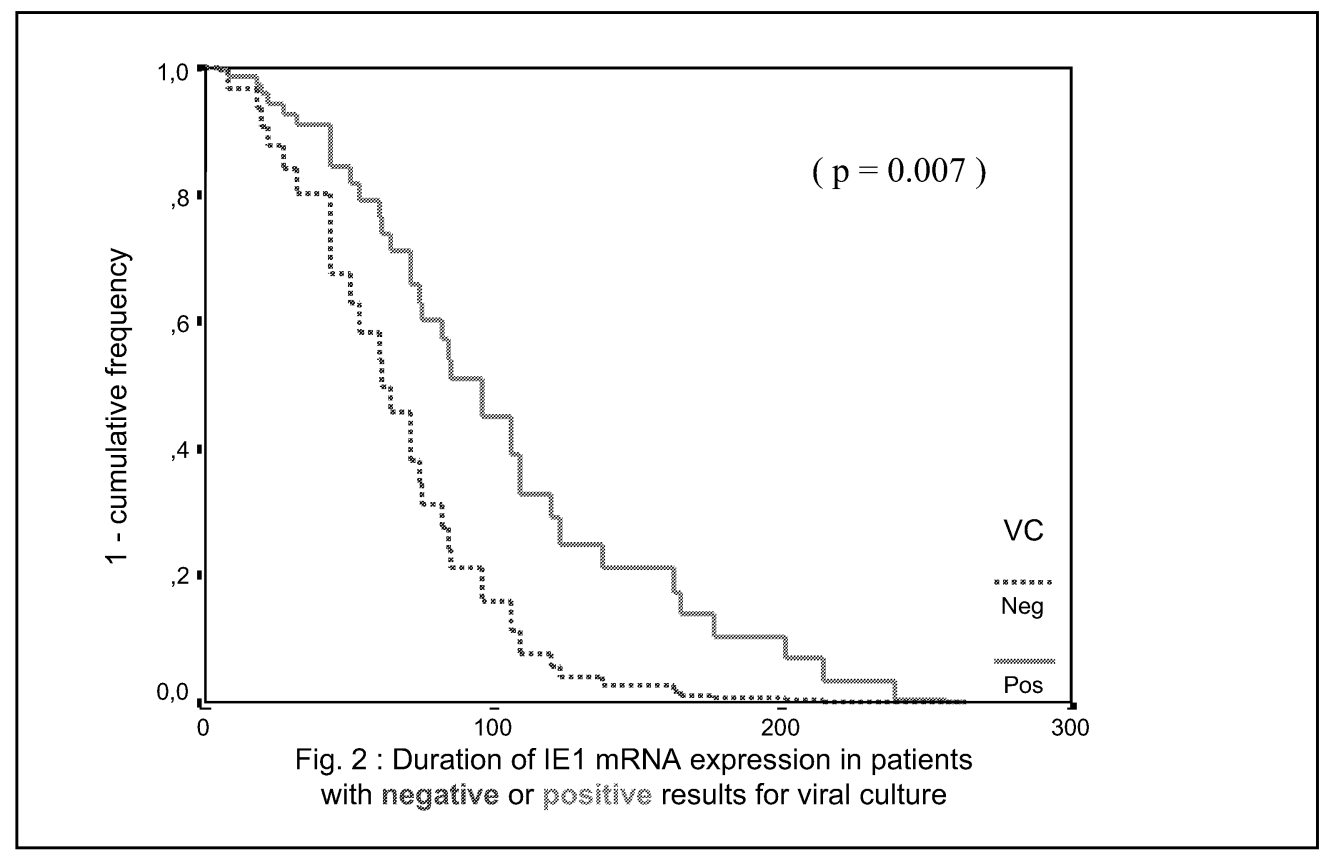

Fig. 2. Multivariate analysis of the significant $(p=0.007)$ correlation between the isolation of $C M V$ in blood and the duration of immediate early $1 \mathrm{mRNA}$ expression. The X-axis indicates the number of days between the first and the last positive IEI NASBA result.

\section{Discussion}

It has been reported that the detection of CMV IE1 mRNA in blood using NASBA is an early sign of CMV infection and precedes other tests, e.g. antigenemia, viral culture and pp67 NASBA [Goossens et al., 1999; Goossens et al., 2000]. In this study, these results were confirmed. In addition, all positive results of viral culture, antigenemia and pp67 NASBA were accompanied by and often even preceded by IE1 positivity. In this way, IE1 positivity can be seen as a "conditio sine qua non" for an active CMV infection.A similar IE1-based diagnostic approach is described by Greijer et al. [2002]. The importance of IE1 mRNA expression is indicated further by growing evidence that the pathogenic features of CMV are largely due to IE gene expression [Cinatl et al., 1999]. We were therefore interested in external factors influencing the appearence and the disappearence of IE1 mRNA. To study this, emphasis was placed on the results of recipients with at least two samples positive for IE1. An attempt was made to find out whether there were selected subgroups of patients with differences in the IE1 mRNA expression. To study such differences, we calculated for each selected subgroup the median value for onset and duration of IE1 mRNA expression. Statistical analysis was completed by bivariate and multivariate analysis.

It was found that, the onset of IE $1 \mathrm{mRNA}$ expression is earlier independently and significantly in patients treated with MMF ( $\mathrm{p}=0.002$ ) and in patients which will develop an active CMV infection as expressed by 
positive antigenemia $(p=0.001)$ and/or viral culture results $(p=0.05)$. MMF is an immunosuppressive agent that exerts relatively selective antiproliferative effects on $\mathrm{T}$ and $\mathrm{B}$ lymphocytes and has been successfully introduced into clinical practice with evident benefits for renal transplant recipients [Simmons et al., 1997]. MMF treatment not only results in a reduction of the incidence of acute rejections but also leads to reduction of late allograft loss [EMMCSG, 1999; Di Landro et al., 2000]. MMF also prevents CMVinduced chronic graft dysfunction [Giral et al., 2001]. Although various multicentre clinical MMF trials failed to show an increase of the overall incidence of CMV infection [TMMRTSG, 1996; Pirsch et al., 1997], it does appear that MMF increases the incidence of tissue invasive CMV disease [Sollinger et al., 1995; Moreso et al., 1998; Zanker et al., 1998; Sarmiento et al., 2000]. Recently it was also reported that the onset of CMV infection could be detected significantly earlier in MMF treated patients [Szymczakiewicz-Multanowska et al., 2001]. In our study, we found a similar correlation between MMF therapy and early CMV detection as expressed by early IE1 mRNA expression. Although our results suggest that MMF treatment may induce differences in IE1 mRNA expession, the exact mechanism by which MMF plays a role in CMV infection remains unclear.

Treatment with ganciclovir was not correlated with the onset and/or duration of IE1 mRNA expression. At first sight, this seems to be remarkably because ganciclovir is an antiviral product highly active against cytomegalovirus. Ganciclovir has been proven to be effective for prophylactic, preemptive and therapeutic use in patients with CMV infection [Singh, 2001]. However, the antiviral activity of ganciclovir is based on the inhibition of the viral DNA polymerase [Nevins et al., 1992], which activity is situated in the late phase of viral gene expression and viral replication. Therefore, ganciclovir is a strong and selective inhibitor of the viral DNA polymerase, but has no effect on the foregoing expression of IE1 mRNA.

For the duration of IE1 mRNA expression, remarkable differences were found that were correlated with age, prednisolone use, active CMV infection as expressed by positive viral cultures and the gB type of isolated CMV strains. There is a striking difference in the duration of IE1 mRNA expression in patients at the age of 15 to 59, compared to patients at the age of 60 tot 75 years old (table 1). The finding that age plays a role in (viral) infections is a known phenomenon. It is well-documented that immunocompetence, and especially thymic function, declines with age [Chakravarti and Abraham, 1999] and age-related T cell alterations are associated with prior CMV infection [Looney et al., 1999; Olsson et al., 2000]. Obviously, further investigations are needed to determine whether the immune control of CMV in elderly patients is ineffective, and whether this has pathological consequences [Emery; 2001].

Our findings concerning the influence of prednisolone on the IE1 mRNA expression are surprisingly. A potential role of prednisolone intake in the IE1 mRNA expression was suggested by the fact that the median day of prednisolone stop coincidenced with the median day of disappearence of IE1 NASBA positivity. However, the median values of the duration of IE1 mRNA expression indicated a correlation between longer prednisolone use and a decreased IE1 duration. This was confirmed by multivariate analysis revealing that prolonged prednisolone treatment was significantly associated with a shorter duration of IE $1 \mathrm{mRNA}$ expression. In the current literature, there is little information available about the interaction of glucocorticoids and CMV mRNA expression in human blood cells. In vitro, pharmacological concentrations of glucocorticoids increased the synthesis of human CMV immediate early proteins and antigens in human embryonic lung cells [Tanaka et al., 1984], and in differentiated monocytes [Lathey and Spector, 1991; Lee et al., 1999]. In vivo, a protective effect of glucocorticoids against CMV-induced lethality was described, although only in glucocorticoid deficient mice [Ruzek et al., 1999]. Nevertheless, detailed information is available about the interaction between glucocorticoids and nuclear factor kappa B (NFkB) and also about the interaction between NFkB and IE1 mRNA expression. The expression of IE1 in human CMV is under the control of a strong transcriptional enhancer [Boshart et al., 1985; Thomsen et al., 1984] referred to as the major immediate early (MIE) promoterenhancer. The unusually strong activity of this MIE promoter-enhancer is due to the presence of multiple binding sites for cellular transcription factors, e.g. NFkB [Prosch et al., 1995; Mocarski, 1996; Kanekiyo et al., 2001]. However, NFkB activation is inhibited by corticosteroids [Scheinman et al., 1995; Barnes, 1997; Wissink et al., 1998; Almawi and Melemedjian, 2002]. This means that in CMV infected patients 
without prednisolone intake, NFkB can activate the MIE promoter-enhancer resulting in increased expression of IE1 mRNA. Otherwise, we hypothesize that in CMV infected patients with prednisolone intake, activation of the MIE promoter-enhancer by NFkB will be blocked resulting in a decreased expression of IE1 mRNA. This hypothesis is in agreement with recent studies describing a reduced stimulation of the MIE promoter-enhancer by specific inhibition of NFkB signalling [Prosch et al., 2002] and an attractive anticytomegaloviral potential of NFkB blockade [Caposio et al., 2003]. Additional research is necessary to investigate whether there is also a direct effect of prednisolone repressing IE promoter activity.

An interesting finding is that statistically significant differences in the duration of IE $1 \mathrm{mRNA}$ expression were found in patients who were infected with either gB1 CMV strains or other gB CMV strains. In this study, $\mathrm{gB}$ genotyping was performed on extracts from low passage clinical isolates. Therefore, selection of particular strains with rapidly growing phenotypes cannot be excluded, although, according to Mousavi-Jazi et al. [2000], growth phenotypes of CMV isolates do not correlate with gB genotypes. In the literature, CMV infection with the gB1 CMV strain was associated with a lower mortality compared to infection with gB types 2-4 in bone marrow transplant recipients [Fries et al., 1994] and in HIV-infected patients [Bongarts et al., 1996]. Later on, this was confirmed by a significant predominance of gB type 2 in bone marrow transplant recipients with CMV disease [Hebart et al., 1997; Woo et al., 1997], but not in renal transplant recipients [Vogelberg et al., 1996; Woo et al., 1997]. In patients with advanced human immunodeficiency virus disease, viremia caused by $\mathrm{gB}$ group $2 \mathrm{CMV}$ strains is associated with higher risk of CMV retinitis than viremia caused by other CMV gB groups [Shepp et al., 1996]. Also a significant association of CMV gB type 3 and 4 with death from myelosuppression after marrow transplantation was found [Torok-Storb et al., 1997]. These in vivo studies suggest that, at least in some groups of immunocompromised patients, there is a more favorable clinical outcome in $\mathrm{gB}$ type 1 infected patients and a higher risk for symptomatic CMV infection or CMV disease in patients infected with gB types 2,3, or 4 . How $\mathrm{gB}$ contributes to these virulence differences is unknown but $\mathrm{gB}$ type $1 \mathrm{CMV}$ did not infect $\mathrm{T}$ lymphocytes whereas gB types 2 and 3 did [Sweet, 1999]. Further in vitro studies on the gB glycoprotein indicate that the interaction of $\mathrm{gB}$ with a yet unidentified cellular receptor, is an important mechanism by which CMV alters cellular gene expression [Simmen et al., 2001].

In conclusion, the present study demonstrates that IE1 mRNA expression starts earlier in MMF treated patients and in patients that will develop an active CMV infection. IE1 mRNA expression lasts longer in patients with early onset of the IE1 mRNA expression, and in patients with an active CMV infection. In contrast, prednisolone use appears to be correlated with a decreased duration of IE1 mRNA expression. Similarly, in patients infected with gB type 1 CMV strains, the duration of IE1 mRNA expression was significantly decreased compared to patients infected with non-gB type $1 \mathrm{CMV}$ strains. The onset and/or duration of CMV IE1 mRNA expression, and especially the precise role herein of CMV gB type and immune suppression, has to be evaluated further.

\section{Acknowledgements}

The authors thank Prof. R. Pusztai of the Department of Medical Microbiology and Immunobiology of the University of Szeged (Hungary) for her interest in the study. The genotyping of the isolated CMV strains was made possible by Grant OTKA-T26442 of the Hungarian Scientific Research Fund.

\section{References}

Almawi WY, Melemedjian OK. 2002. Negative regulation of nuclear factor-kappaB activation and function by glucocorticoids. J Molec Endocrin 28:69-78.

Barnes PJ. 1997. Molecules in focus: Nuclear Factor Kappa B. Int J Biochem Cell Biol 29:867-870.

Blok MJ, Goossens VJ, Vanherle SJV, Top B, Tacken N, Christiaans MH, Van Hooff J, Bruggeman CA. 1998. Diagnostic value 
of monitoring human cytomegalovirus late pp67 mRNA expression in renal-allograft recipients by nucleic acid sequence-based amplification. J Clin Microbiol 36(5):1341-1346.

Blok MJ, Christiaans MHL, Goossens VJ, Van Hooff JP, Sillekens P, Middeldorp JM, Bruggeman CA. 1999. Early detection of human cytomegalovirus infection after kidney transplantation by nucleic acid sequence-based amplification. Transplantation 67(9):1274-1277.

Bongarts A, von Laer D, Vogelberg C, Ebert K, von Lunzen J, Garwegg J, Vaith P, Hufert FT, Haller O, Meyer-Konig U. 1996. Glycoprotein B genotypes of human cytomegalovirus; distribution in HIV-infected patients. Scand J Infect Dis 28:447-449.

Boshart M, Weber F, Jahn G, Dorsch-Hasler K, Fleckenstein B, Schaffner W. 1985. A very strong enhancer is located upstream of an immediate early gene of human cytomegalovirus. Cell 41:521-530.

Caposio P, Di Nicola A, Riera L, Dreano M, Garotta G, Gribaudo G, Landolfo S. 2003. Inhibition of IKK2 activity inhibits human cytomegalovirus replication and virus-induced NF-kB activity. Abstract J.03 (p81) in the Abstract Book of the $9^{\text {th }}$ International Cytomegalovirus Workshop and $1^{\text {st }}$ International Betaherpesvirus Workshop May 20-25, 2003, Maastricht, the Netherlands.

Chakravarti B, Abraham GN. 1999. Aging and T-cell-mediated immunity. Mech Ageing Dev 108(3):183-206.

Cinatl J, Vogel JU, Kotchetkov R, Scholz M, Doerr HW.1999. Proinflammatory potential of cytomegalovirus infection. Intervirology 42:419-424.

Di Landro D, Sarzo G, Marchini F. 2000. New immunosuppressive treatment in kidney transplantation. Clin Nephrol 53:23-32.

Emery VC. 2001. Cytomegalovirus and the aging population. Drugs \& Aging 18:927-933.

European Mycophenolate Mofetil Cooperative Study Group. 1999. Mycophenolate mofetil in renal transplantation: 3-year results from the placebo-controlled trial. Transplantation 68:391-396.

Fries BC, Chou S, Boeckh M, Torok-Storb B. 1994. Frequency distribution of cytomegalovirus envelope glycoprotein genotypes in bone marrow transplant recipients. J Infect Dis 169:769-774.

Giral M, Nguyen JM, Daguin P, Hourmant M, Cantarovich D, Dantal J, Blancho G, Josien R, Ancelet D, Soulillou JP. 2001. Mycophenolate mofetil does not modify the incidence of cytomegalovirus (CMV) disease after kidney transplantation but prevents CMV-induced chronic graft dysfunction. J Am Soc Nephrol 12:1758-1763.

Goossens VJ, Blok MJ, Christiaans MHL, Van Hooff JP, Sillekens P, Höckerstedt K, Lautenschlager I, Middeldorp JM, Bruggeman CA. 1999. Diagnostic value of nucleic-acid-sequence-based amplification for the detection of cytomegalovirus infection in renal and liver transplant recipients. Intervirology 42:373-381.

Goossens VJ, Blok MJ, Christiaans MHL, Sillekens P, Middeldorp JM, Bruggeman CA. 2000. Early detection of cytomegalovirus in renal transplant recipients: comparison of PCR, NASBA, pp65 antigenemia, and viral culture. Transplant Proc 32:155-158.

Greijer AE, Adriaanse HMA, Dekkers CAJ, Mideldorp JM. 2002. Multiplex real-time NASBA for monitoring expression dynamics of human cytomegalovirus encoded IE1 and pp67 RNA. Journal of Clinical Virology 24:57-66.

Grundy JE. 1998. Current antiviral therapy fails to prevent the pro-inflammatory effects of cytomegalovirus infection, whilst rendering infected cells relatively resistant to immune attack. Monogr Virol, Basel, Karger 21:67-89.

Hebart H, Greif M, Krause H, Kanz L, Jahn G, Muller CA, Einsele H. 1997. Interstrain variation of immediate early DNA sequences and glycoprotein B genotypes in cytomegalovirus clinical isolates. Med Microbiol Immunol (Berl) 186(2-3):135-138.

Holma K, Törnroth T, Grönhagen-Riska C, Lautenschlager I. 2000. Expression of the cytomegalovirus genome in kidney allografts during active and latent infection. Transpl Int 13(Suppl 1):S363-S365.

Kanekiyo M, Itoh N, Kawasaki A, Tanaka J, Nakanishi T, Tanaka K. 2001. Zinc-induced activation of the human cytomegalovirus major immediate-early promoter is mediated by metallothionein and nuclear factor-kappaB. Toxocol Appl Pharmacol 173:146-153.

Kraat YJ, Christiaans MHL, Nieman FHM, van den Berg-Loonen PM, van Hooff JP, Bruggeman CA. 1994. Risk factors for cytomegalovirus infection and disease in renal transplant recipients: HLA-DR7 and triple therapy. Transpl Int 7:362-367.

Lathey JL, Spector SA. 1991. Unrestricted replication of human cytomegalovirus in hydrocortisone-treated macrophages. J Virol 65:6371-6375. 
Lee CH, Lee GC, Chan YJ, Chiou CJ, Ahn JH, Hayward GS. 1999. Factors affecting human cytomegalovirus gene expression in human monocyte cell lines. Mol Cells 9:37-44.

Looney RJ, Falsey A, Campbell D, Torres A, Kolassa J, Brower C, McCann R, Menegus N, McCormick K, Frampton M, Hall W, Abraham GN. 1999. Role of cytomegalovirus in the T cell changes seen in elderly individuals. Clinical Immunology 90:213219.

Lukacsi A, Tarodi B, Endreffy E, Babinszki A, Pal A, Pusztai R. 2001. Human cytomegalovirus gB genotype 1 is dominant in congenital infections in South Hungary. J Med Virol 65:537-542.

Mousavi-Jazi M, Sundqvist VA, Linde A, Wahren B, Brytting M. 2000. Growth phenotypes of cytomegalovirus isolates do not correlate with glycoprotein B, major immediate early genotypes or antiviral susceptibility. J Med Virol 62:117-126.

Miller DM, Sedmak DD.1998. Cytomegalovirus persistence: escape from cell-mediated immunosurveillance. Monogr Virol, Basel, Karger 21:1-11.

Mocarski ES. 1996. Cytomegaloviruses and their replication. In: Fields BN, Knipe DM, Chanock RM, et al, eds. Fields Virology. $3^{\text {rd }}$ ed. Vol.2 New York: Raven Press 3:2447-2492.

Moreso F, Seron D, Morales JM, Cruzado JM, Gil-Vernet S, Perez JL, Fulladosa X, Andres A, Grinyo JM. 1998. Incidence of leukopenia and cytomegalovirus disease in kidney transplants treated with mycophenolate mofetil combined with low cyclosporine and steroid doses. Clin Transplant 12:198-205.

Nevins TE, Dunn DL. 1992. Use of ganciclovir for cytomegalovirus infection. J Am Soc Nephrol 2(12 Suppl):S270-S273.

Olsson J, Wikby A, Johansson B, Lofgren S, Nilsson BO, Ferguson FG. 2000. Age-related change in peripheral blood Tlymphocyte subpopulations and cytomegalovirus infection in the very old: the Swedish longitudinal OCTO immune study. Mechanisms of Ageing and Development 121:187-201.

Pirsch JD, Miller J, Deierhoi MH, Vincenti F, Filo RS. 1997. A comparison of tacrolimus (FK506) and cyclosporine for immunosuppression after cadaveric renal transplantation. FK506 Kidney Transplant Study Group. Transplantation 63:977-983.

Prosch S, Staak K, Stein J, Liebenthal C, Stamminger T, Volk HD, Kruger DH. 1995. Stimulation of the human cytomegalovirus IE enhancer/promoter in HL-60 cells by TNF alpha is mediated via induction of NF-kappa B. Virology 208:197-206.

Prosch S, Wuttke R, Kruger DH, Volk HD. 2002. NF-kappa B--a potential therapeutic target for inhibition of human cytomegalovirus (re)activation? Biol Chem 383:1601-1609.

Rubin RH. 1990. Impact of cytomegalovirus infection on organ transplant recipients. Rev Infect Dis 12(suppl 7):S754-S766.

Ruzek MC, Pearce BD, Miller AH, Biron CA. 1999. Endogenous glucocorticoids protect against cytokine-mediated lethality during viral infection. J Immunol 162:3527-3533.

Sarmiento JM, Dockrell DH, Schwab TR, Munn SR, Paya CV.2000. Mycophenolate mofetil increases cytomegalovirus invasive organ disease in renal transplant patients. Clin Transplant 14:136-138.

Scheinman R, Cogswell P, Lofquist A, Baldwin A. 1995. Role of transcriptional activation of 1 kappa B alpha in mediation of immunosuppression by glucocorticoids. Science 270:283-286.

Shepp DH, Match ME, Ashraf AB, Lipson SM, Millan C, Pergolizzi R. 1996. Cytomegalovirus glycoprotein B groups associated with retinitis in AIDS. J Infect Dis 174(1):184-187.

Simmen KA, Singh J, Luukkonen BGM, Lopper M, Bittner A, Miller NE, Jackson MR, Compton T, Früh K. 2001. Global modulation of cellular transcription by human cytomegalovirus is initiated by viral glycoprotein B. Proc Natl Acad Sci USA 98(13):7140-7145.

Simmons WD, Rayhill SC, Sollinger HW. 1997. Preliminary risk-benefit assessment of mycophenolate mofetil in transplant rejection. Drug Saf 17(2):75-92.

Singh N. 2001. Preemptive therapy versus universal prophylaxis with ganciclovir for cytomegalovirus in solid organ transplant recipients. Clin Inf Dis 32:742-751.

Sollinger HW for the U.S. Renal Transplant Mycophenolate Mofetil Study Group. 1995. Mycophenolate mofetil for the prevention of acute rejection in primary cadaveric renal allograft recipients. Transplantation 60:225-232. 
Sweet C. 1999. The pathogenicity of cytomegalovirus. FEMS Microbiology Reviews 23:457-482.

Szymczakiewicz-Multanowska AM, Kuzniewski M, Zawilinska B, Zgorniak-Nowosielska I, Uracz D, Ignacak E, BetkowskaProkop A, Sulowicz W. 2001. Factors influencing prevalence and clinical course of cytomegalovirus (CMV) infection in kidney transplant patients. Przegl Lek 58:772-777.

Tanaka J, Ogura T, Kamiya S, Sato H, Yoshie T, Ogura H, Hatano M. 1984. Enhanced replication of human cytomegalovirus in human fibroblasts treated with dexamethasone. J Gen Virol 65:1759-1767.

The Tricontinental Mycophenolate Mofetil Renal Transplantation Study Group. 1996. A blinded, randomized clinical trial of mycophenolate mofetil for the prevention of acute rejection in cadaveric renal transplantation. Transplantation 61:1029-1037.

Thomsen DR, Stenberg RM, Goins WF, Stinski MF.1984. Promoter-regulatory region of the major immediate early gene of human cytomegalovirus. Proc Natl Acad Sci USA 81:659-663.

Torok-Storb B, Boeckh M, Hoy C, Leisenring W, Myerson D, Gooley T. 1997. Association of specific cytomegalovirus genotypes with death from myelosuppression after marrow transplantation. Blood 90(5):2097-2102.

Van der Bij W, Schirm J, Torensma R, Van Son WJ, Tegzess AM, The TH. 1988. Comparison between viremia and antigenemia for detection of cytomegalovirus in blood. J Clin Microbiol 26:2531-2535.

Van Hooff, JM Boots, EM van Duijnhoven, MH Christiaans. 1999. Dosing and management guidelines for tacrolimus in renal transplant patients. Transplant Proc 31(7A):54S-57S.

Vogelberg C, Meyer-Konig U, Hufert FT, Kirste G, von Laer D. 1996. Human cytomegalovirus glycoprotein B genotypes in renal transplant recipients. J Med Virol 50(1):31-34.

Wissink S, van Heerde EC, van der Burg B, van der Saag PT.1998. A dual mechanism mediates repression of NF-kappaB activity by glucocorticoids. Mol Endo 12:355-363.

Woo PC, Lo CY, Lo SK, Siau H, Peiris JS, Wong SS, Luk WK, Chan TM, Lim WW, Yuen KY. 1997. Distinct genotype distributions of cytomegalovirus (CMV) envelope glycoprotein in bone marrow and renal transplant recipients with CMV disease. Clin Diagn Lab Immunol 4(5):515-518.

Zanker B, Schneeberger H, Rothenpieler U, Hillebrand G, Illner WD, Theodorakis I, Stangl M, Land W. 1998. Mycophenolate mofetil-based, cyclosporine-free induction and maintenance immunosuppression: first-3-months analysis of efficacy and safety in two cohorts of renal allograft recipients. Transplantation 66:44-49. 
Chapter 6

\title{
A DELAY IN CD4 CELL RESPONSE AFTER INITIATION OF HIGHLY ACTIVE ANTIRETROVIRAL THERAPY IS ASSOCIATED WITH THE PRESENCE OF ANTI-CYTOMEGALOVIRUS BUT NOT WITH ANTI-HERPES SIMPLEX VIRUS ANTIBODIES
}

\author{
Valère J. Goossens ${ }^{1}$, Gerrit Schreij ${ }^{2}$, Siebe van der Geest ${ }^{2}$, Danitsja M. van Leeuwen ${ }^{1}$, \\ Dominique C. Baas ${ }^{1}$, Cathrien A. Bruggeman ${ }^{1}$, André J. van der Ven ${ }^{1}$ \\ ${ }^{1}$ Department of Medical Microbiology, University Hospital Maastricht \\ ${ }^{2}$ Department of Internal Medicine, University Hospital Maastricht
}



A delay in CD4 cell response after initiation of highly active antiretroviral therapy is associated with the presence of anti-cytomegalovirus but not with anti-herpes simplex virus antibodies

Valere 1. Goossens, Gernt Schrebl, Siebe van der Geest ${ }^{b}$ Danitsia M. van Leewenen, Dominique C. Baas", Cathrien A. Bruggeman and André I. van der Ven ${ }^{3}$

After the successful initiation of highly active antiretroviral therapy (HAART) in HIV-1-infected patients, the mean CD4 cell response was lower in cytomegalovirus (CMV)-seropositive patients than in $C M V$-seronegative patients $(P<0.05)$. The difference between the mean CD 4 cell counts of CMV-seronegative and CMV-seropositive patients was maximal $\left(163 \times 10^{6} / 1\right)$ at 76 weeks after the start of HAART, and decreased gradually thereafter. No association was found between herpes simplex virus types 1 and 2 serostatus and $\mathrm{CD} 4$ cell response.

The interaction between HIV -1 and cytomegalovirus (CMV) has been demonstrated in numerous epidemiological, pathological and in-vitro molecular studies [1]. Various studies have demonstrated that CMV infection is associated with a more rapid progression of HIV disease $[2-4]$. However, there are conflicting data as to wherher or not this adverse effect of CMV is mediated via a more rapid loss of CD4 cells. Apart from CMV, other herpesvinuses, such as herpes simplex virus type 1 (HSV-1) or type 2 (HSV-2), also are known to act as viral co-factors for HIV [5]. Most data, however, are derived from in-vitro studies and only very limited invivo data are available [6]. The multiple mechanisms by which different herpesviruses may interact with HIV have been reviewed by Griffiths [5]. In addition, antiherpes drugs may be able to inhibit the progression of HIV disease [7]. Conversely, most antiretroviral drugs only suppress HIV replication, and do not have a direct effect on herpesviruses. Highly active antiretroviral therapy (HAART) leads to the suppression of HIV replication and allows a recovery of the cellular immune functions. This immune recovery, expressed by an increase in the CD4 cell count in blood, is characterized by a better immunological control of opportunistic infections such as herpesvirus infections. However, in some patients the recovery of CD4 cells appears to be delayed or to remain incomplete. We therefore studied whether seropositivity for herpesviruses (CMV, HSV -1 and HSV-2) influences the CD4 cell response after the successful initiation of HAART in HIV-1-infected patients.

The study was conducted in the AIDS Clinic of the University Hospital Maastricht (the Netherlands), at which an observational clinical cohort of 128 HIV-1seropositive subjects participate in the national ATHE NA project [8]. All 128 subjects were treated with HAART. The HIV -1 viral load and CD4 cell count were measured at least exery 3 months. As HIV-1 replication itself can induce a decline in CD4 cells, only patients $(n=62)$ with undetectable HIV -1 viral loads, measured 24 weeks after the initiation of HAART, were included in this study. Thereafter, the patients were followed for as long as the viral load remained undetectable. After 52, 76, 100 and 124 weeks of HAART, viral load results were continuously undetectable in 48, 30, 23 and 21 patients, respectively. The serostatus of all patients was detemined at the onset of HAART. The presence of anti-CMV IgG antibodies was detected using the VIDAS CMV IgG assay (BioMerieux, 's Hertogenbosch, the Netherlands). HSV -1 and HSV -2 antibodies were detected using the SeroHSV1 and SeroHSV2 diagnostic kits (Sayyon Diagnostics Ltd., Ashdod, Israel). CMV seropositivity was found in 48 patients (group 1) and 14 patients were CMV-seronegative (group 2). The characteristics of groups 1 and 2 patients at the onset of HAART are described in Table 1. At that time, the group of CMVseropositive patients matched very well with the group of CMV-seronegative patients, and there were no differences between the two groups except for intravenous drug use and HSV -2 seropositivity.

The CD4 cell response after the intiation of HAART in groups 1 and 2 patients is demonstrated in Fig. 1. In the period between 12 and 76 weeks of HAART, the mean increase in CD4 cell counts for CMV-seropositive patients was $81 \times 10^{6} \mathrm{CD} 4$ cells $/$, compared with an increase of $241 \times 10^{6} \mathrm{CD} 4 \mathrm{cells} / 1$ for $\mathrm{CMV}$-sero- 
Table 1. Baselne characteristic of chomegalovirussecoposive (group 1 and cyomegalow vinus-seronegatve (group 2$)$ patents at the onset of highy actwe antretroviral therapy.

\begin{tabular}{|c|c|c|}
\hline Characteristcs & Croup 1 & Group 2 \\
\hline Number of patients & 46 & 14 \\
\hline Age (yours, mean - Sma & $43.9(11.2)$ & $4(.7,02.4)$ \\
\hline Male & $38(79 \%)$ & $1 /(79 \%)$ \\
\hline ADS dhognosis & $13(27 \%)$ & $4(29 \%)$ \\
\hline HV infection idays mear 458 & $1794(199)$ & $2009(+375)$ \\
\hline \multicolumn{3}{|l|}{ Transmission roule } \\
\hline Intravenous drug abuse & $4(8 \%)$ & $4(28.5 \%)$ \\
\hline Homobisexual & $29(60 \%)$ & $6(43 \%)$ \\
\hline ower & $1801 \%$ & $4(28.5 \%)$ \\
\hline Arvinetrowial nave & $36075 \%$ & $12(86 \%)$ \\
\hline \multicolumn{3}{|l|}{ Antretroviral regimens: } \\
\hline at least three drugs, including apl & $46[96 \%$ & 14000\% \\
\hline cou cell count mean $-5 B$ & $264 \div 29$ & $289(-48)$ \\
\hline Cob cell count mean -50$)$ & $919(073)$ & $992-198)$ \\
\hline CDA:CDB cell who mean 1 - SE & $0.286(-0.080)$ & $0.352(+0.112)$ \\
\hline HW 1 load mean 4 SE) & $196291(-35674)$ & $204724(466366)$ \\
\hline CMVIgG: mean \& $\$ D$ & $629( \pm 133)$ & $\mathrm{NA}$ \\
\hline HSW I seropositive & $3676 \%$ & $1,17,4)$ \\
\hline HSU 2 szaronoxinues & $25<3 \%$ & $3 / 28 \%$ \\
\hline
\end{tabular}

HSV, Herpes simplex wins; Protease inhbitor.

SEE Stwd dard eror of the mean. Signitant dfferences $(P<0.05)$ beween both groups onl

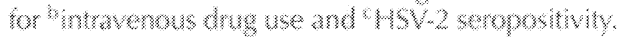
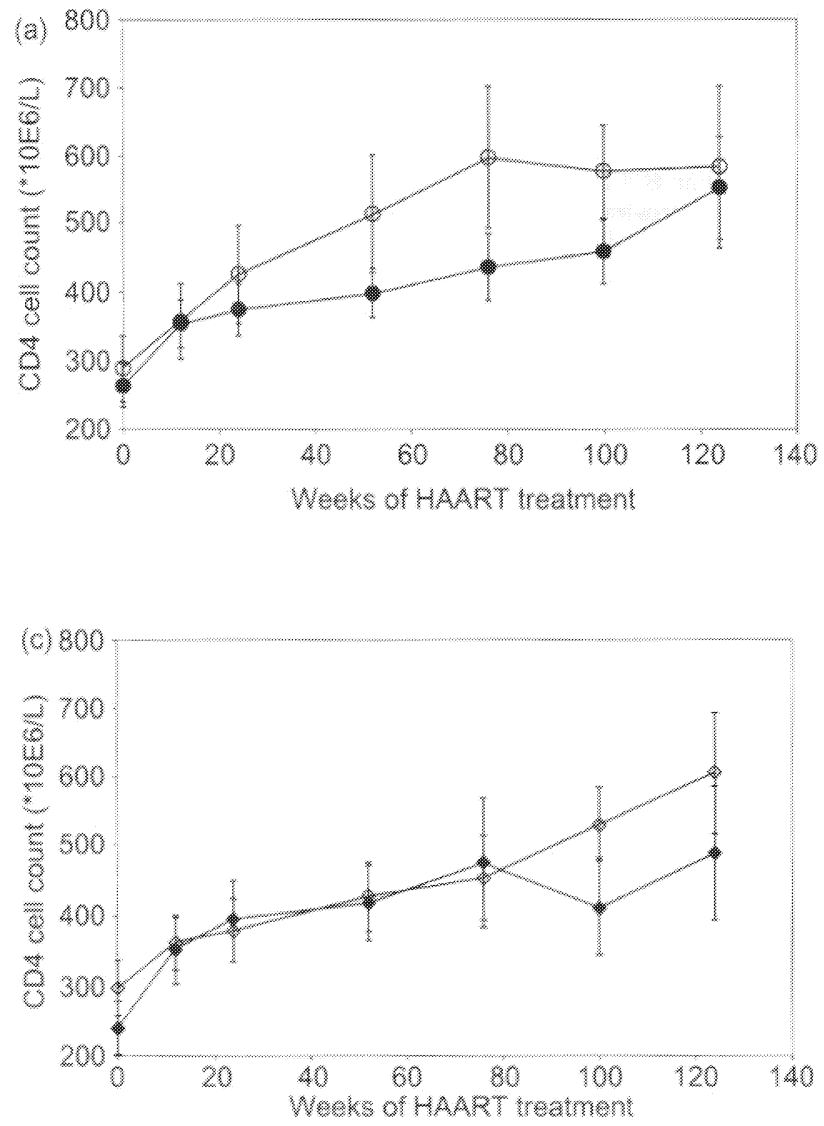

negative patients. Ar 76 weeks of HAART, there was a maximal difference of $163 \times 10^{6}$ cells $/$ between the mean CD4 cell counts of CMV-seronegative and CMV-seropositive patients. Also, the proportion of patients who attained CD4 cell levels of at least 500 and $600 \times 10^{6}$ cells/ at 76 weeks of HAART was

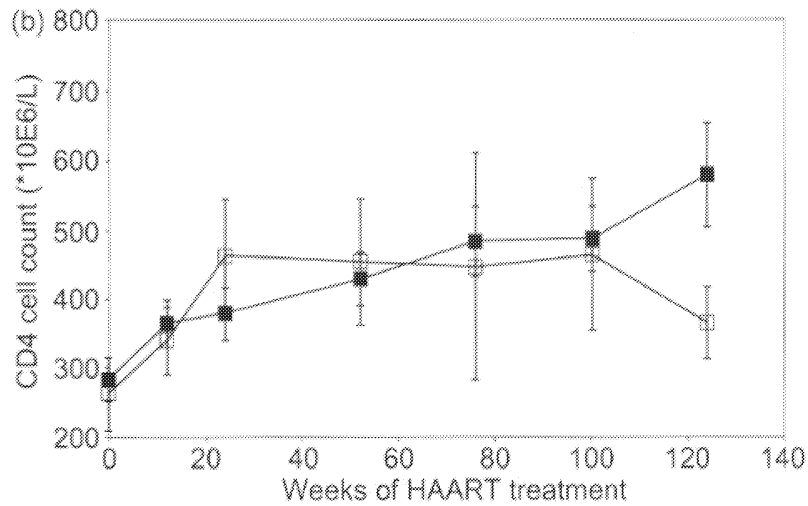

Fig. 1. Evolution of the CD4 cells In HV 1 patents at onset and ater $12,24,52,76,100$ and 124 wecks of highy actue antretrownal theapy according to cytomegalovius $(\alpha)$ herpes simplex virus type $1 \mathrm{~b}$ and herpes simplex wirus type 2 (c) serology. A these wimepoints, the mean number of $\mathrm{CD} 4$ cells were 264 and 289,354 and 357,374 and 426,398 and 514,435 and 598,458 and 576,552 and $583 \times 10^{6}$ cellst

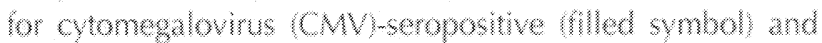
CMV-serongatve patents lopen symbol, respechely. CM-seropositive patients have a temporary but signticant $(P<0.05)$ delay in CD cell response compared wh CMV seronegatwe pathents (a). No signtwant dherences In CD4 cell counts were noted wh thegard to herpes simplex virus type 1 (HSV.1) (b) or type 2 (HSV-2) (c) serology. HAART, Hghly active antretrovid herapy.

significantly ( $P$ values of 0.05 and 0.01 , respectively) higher in the CMV wseronegative patient group than in the CMV-seropositive patient group (data not shown). For CMV-seronegative patients, a maximal, long-lasting and more or less constant level of CD4 cells was reached after 76 weeks of HAART. In contrast, for 
CMV-seropositive patients, the slower increase in $\mathrm{CDA}$ cell cownts continued wntl, at least 124 weeks after the intation of $\mathrm{HAART}, \mathrm{CD} 4$ cell levels were reached that were simbar to those for CMV-seronegative patents. CMV-seropositive patients thus show a temporm ary (mem 32 weeks; 95\% conhdence interval 1-94 weeks) but significant delay in recovery of $\mathrm{CD} 4 \mathrm{cell}$. In contrast to $\mathrm{CMV}$, no differences in mean $\mathrm{CD}$. cell counts were noted, associated with HSV 1 or HSV-2 serostatus. The temporary delay ${ }^{n} \mathrm{CD} 4$ cell response in CMV-seropositve patients is in agrecnent with the fudings of Kovace of a. (1). The authors described that CMV-infected chidren, who were born to HV-1infected women, were found to have lower CD4 cell counts und 15 months of age, in comparion with CMV-minfected chldren.

Several factors are known to infuence CD4 cell response, both HNV-related factors such as antretrovinal drugs, baselne plasma tral load and CD 4 cell coum, and non-HIV-related factors, such as age and sex 19,10]. Combined antretrovinal therapy of HIV-positive patients with reduced blood CD4 cell counts dramatically reduces vical teplication and results in an morease in both CD4 and CD8 lymphocytes in the blood $(11,12)$. In the present study, perfomed in well matched patient groups, none of these factors infum enced the CD4 cell responses, except the CMV serostatux. All patients, included, who were treated with mple ant-HIV therapy, including a protease mhibitor $(n=60)$ or nevirpine $(n=2)$, showed concinuously undetectable MV -1 vinl loads. It is therefore whlkely that the extent of virus suppression that was acheved during HAART difered between the two groups studied.

In conclusion, in the first 2 years after the indution of HAART in HV-1-infected patients, CMV-seroposiwive patients have a temporary but significant delay in $\mathrm{CD} 4$ cell count restontion in peripheral blood compared with CMV-seronegatve patent. No significant CD4 cell delay after HAART in HIV-1-infected paterts was found in HSV-1- or HSV-2-seroposivive patente compared will HSV-1- or $\mathrm{HSV}-2$-seronegatwe patients

Deparments of Medical Microbiology and bntemal Medicine, University Hospial Maastricht, Maastricht the Netherlands.

Received: 16 November 2001; revised: 22 March 2002; accepted: 8 April 2002.

\section{References}

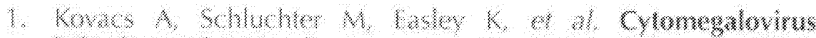
infection and HV. disease progresston in infant born 10 HV. infected women. N Ling// Med 1090, 34177 -84,

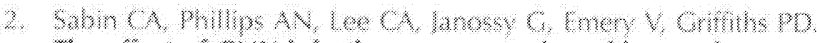
The effect of CMV infection on progressixn of human immuno

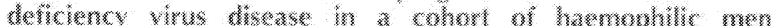
followed for up to 13 years from serocanverswon. Gyolowhol mke1 1996, $14: 361,-372$.

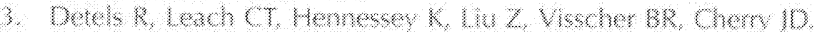
Persistent cylomegabvirus infecton of semen hereases risk of ADS. / Intect Dis 1994, $160,766-768$.

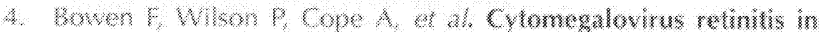
AIOS paterts: influence of cylomegaloviral load on response to ganciclovir, time to recurrence and survival, AlOS 1006, 10: $1855-1520$

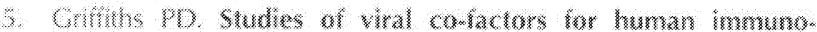
defciency verus in who and in who. Gen. Whol 1048, 79 . 213,220

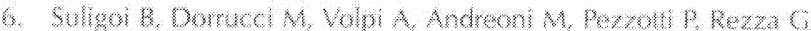
tor the twhan seroconvershn study. Absence of an efrect of

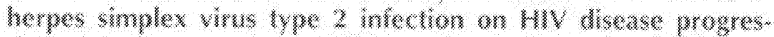
sion: data from a cohort of HIV posttve indivituals wibl known date of semoconversion. AlOS $2001,15: 113-135$.

*. Stein DS. craham WM merachon of herpes wheses wh WW:

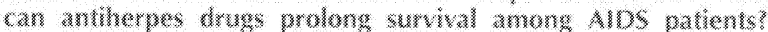
Rel Red Whol $1996,6: 163-172$.

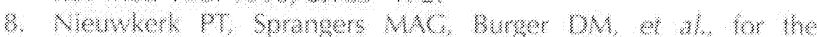
ATICSA project, Lmiled patient adherence 10 highly actwe antiretrowinal herapy for HW-1 werenen in an observational

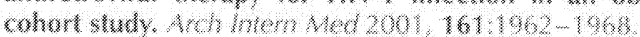

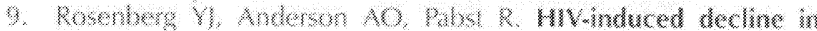

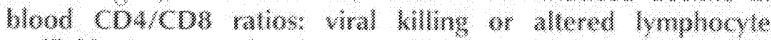

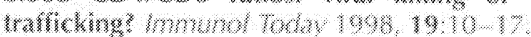

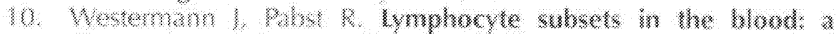

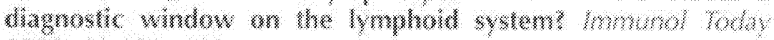
$1900,11,406-10$

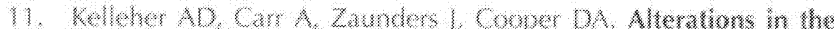
mmune response of hwman immunodeficiency virus (HW).

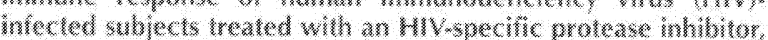

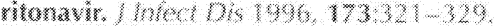

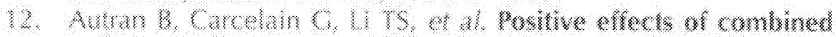

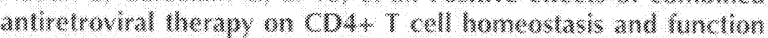

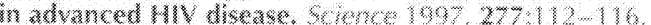


Chapter 7

SUMMARY, GENERAL DISCUSSION AND CONCLUSIONS 



\section{Summary, general discussion and conclusions}

Infections with human CMV are very common. In general, infections of immunocompetent individuals remain asymptomatic. In contrast, infections of immunocompromised patients, such as AIDS patients, solid organ and bone marrow transplant recipients, can result in a symptomatic infection and may even lead to death. While transplant recipients are highly at risk for pneumonitis and hepatitis, AIDS patients more often develop CMV colitis, retinitis and encephalitis. Currently, effective antiviral treatment is possible. At the moment, ganciclovir is the most commonly used antiviral drug for the prevention and treatment of symptomatic CMV infection. In the near future, oral drugs such as valganciclovir will propably become the most important antiviral treatment for CMV [103]. Antiviral treatment is most effective when the patient is treated at an early stage of infection $[12,38,39,82]$. In general, the preferred approach is therefore to initiate antiviral treatment before onset of apparent symptoms of infection. This preemptive strategy relies on the early detection of aberrant CMV activity using a diagnostic assay. On the other hand, due to adverse side effects of the drug and possible development of viral resistance against the drug, treatment of patients should be limited. Furthermore, delayed initiation of therapy may allow priming of host antiviral immune responses which may contribute to recovery and long-term control of the infection. Therefore, a diagnostic assay, or a combination of diagnostic assays, should: i) allow the clinician to detect an infection with CMV as early as possible, and ii) give additional information to the clinician whether or not the patient has developed an active CMV infection that might be treated with antiviral drugs.

In the following discussion we will focus on "classic" techniques for diagnosis of CMV infection such as virus culture and antigenemia and "newer" techniques such as PCR and NASBA. Beside general overview of these techniques and their use in the diagnostic laboratory, our results obtained and described in this thesis will be discussed.

\section{CMV culture}

Cytomegalovirus may be recovered from body fluids or tissues obtained by biopsy or at autopsy. Human CMV has been isolated from urine, blood, throat washings, saliva, tears, milk, stool [28], and vaginal or cervical secretions. Viremia, i.e. the presence of virus in blood/blood cells, is an indication of active CMV infection. It occurs in both asymptomatic and symptomatic infections. In general, the amount of viral particles in blood, is correlated with the severity of symptoms and clinical presentation of the CMV infection. To detect CMV in blood, EDTA blood and not heparin blood has to be collected since CMV is inhibited by heparin. It is then centrifuged at $400 \mathrm{x}$ g for $15 \mathrm{~min}$, and about $1 \mathrm{x}$ $10^{6}$ cells of the leukocyte-rich 'buffy-coat' are inoculated onto tube cell monolayer cultures. All samples submitted to the laboratory for virus isolation should be processed within a few hours after collection. Specimens submitted for CMV growth or identification must be inoculated onto human fibroblast cell monolayers. Fibroblast cultures may be obtained as primary cultures prepared from foreskin or embryonic skin and muscle, lung, testes, or myometrium [59] but also serially propagated diploid fibroblast cell strains can be used for isolation of CMV. Low-passage (10-24) cultures are known to be more susceptible than high passage cultures [59]. Fibroblast cultures inoculated with virus-containing material may show CPE in 3-4 days but usually it takes longer ( 1 to 2 weeks or even more), depending on the concentration of virus in the specimen [59]. The typical CMV-induced CPE in fibroblasts starts with foci of enlarged, rounded refractile cells that appear in the center rather than in the periphery of the cell monolayer. Affected cells characteristically follow the linear pattern in which fibroblasts align themselves. These foci will enlarge, coalesce, and may eventually destroy the monolayer, a process that may take 2-3 weeks. At times, foci of infection will enlarge but never involve the entire monolayer unless the infected cells are passed. Occasionally, CPE will not be produced in the originally inoculated cultures. When such cultures are trypsinized and planted on a 
fresh monolayer, CPE may occur. Even within different CMV strains, differences in CPE may occur. Most clinical isolates, as well as the Davies, Esp., and Kerr prototype laboratory strains cause early cell rounding. The nuclei are pushed to the periphery of the cell and are often distorted. A single prominent eosinophilic paranuclear inclusion develops. In contrast, AD169-infected cells retain their fibroblastic shape, nuclear morphology is maintained except for margination, and cytoplasmic inclusions are less distinct and are often bipolar. However, especially for clinical strains, it can take up to 6 weeks before the CPE is observed. Therefore, this technique is unsuitable for rapid diagnosis of CMV infection and early start of preemptive antiviral therapy.

The availability of specific antibodies against CMV antigens has stimulated many laboratories to circumvent the observation of cytopathology in inoculated cultures. In 1984, using a pool of seven CMV-specific monoclonal antibodies determined by immunofluorescence, Griffiths et al. [56] detected CMV antigens in human embryonic lung fibroblasts grown in slide chambers 4 hours after inoculation of patient material. This rapid assay, where a centrifugation step is included [60, 93], is commonly used and is based on the detection of immediate early and/or early antigens in infected cells. Using this rapid assay, also called shell vial assay or DEAFF, immediate early antigen in infected cells can be detected as early as $3 \mathrm{hr}$ after adsorption of laboratory-adapted strains such as AD169 strain, and from 6 to $12 \mathrm{hr}$ after inoculation with clinical specimens containing the virus. Routinely most specimens are incubated overnight after inoculation, after this anti CMV monoclonal antibody to immediate early and/or early antigens is added and antigen-containing cells are detected by indirect immunofluorescence or enzyme-linked detection [117]. It is interesting to note that no rapid virus assay covers all the positive specimens detected by conventional viral culture.

As described in chapter 3, we were able to detect CMV by viral culture in 62 blood samples. Of these 62 positive samples, $58(94 \%)$ were detected by CPE and $25(40 \%)$ were detected by DEAFF. Especially for blood cultures, such a difference between DEAFF and conventional culture has already been described [24]. The sensitivity of shell vial culture can probably be improved by increasing the number of leukocytes inoculated [102]. It is also important to reduce the transport time of specimens prior to culture to avoid false-negative culture results [109]. In our experience, a combination of a negative DEAFF result together with a positive CPE result is probably an indication for a rather low viral load compared to higher viral loads that give positive results in DEAFF and in CPE. From our and other data, it is clear that DEAFF is a significant advance in that it gives a rapid result without losing too much in sensitivity.

However, due to the relatively low levels of infectious virus in blood and body secretions, the sensitivity of both the "classical" technique i.e. detection of CPE and the rapid viral culture (DEAFF) are rather low $[89,94,126]$. Therefore, viral culture is of limited value for monitoring CMV infection, especially during antiviral therapy [11,37], and is accompanied by other, more sensitive and fast techniques such as antigenemia and molecular diagnostic assays for early detection of CMV. In chapter 2, 3 and 4 we present the results of our studies in renal and liver transplant recipients and compare CMV culture with the pp65-antigenemia assay and with molecular diagnostic assays such as PCR and NASBA.

\section{CMV pp65 antigenemia assay}

Several years ago, van der Bij et al. observed that CMV viremia was accompanied by the presence of pp65 antigen positive polymorphonuclear cells (PMNs) in blood [64, 138]. These CMV-antigen positive cells are easily detectable using a monoclonal antibody staining on fixed leukocyte preparations obtained by cytospin centrifugation. Multiple longitudinal studies have resulted in the development of (pre-emptive) therapeutic strategies, using the number of pp65 positive PMNs as a 
diagnostic criterion [14]. However, as PMNs are short-lived and lack the appropriate transcription factors, they rarely support productive CMV infection themselves [51]. The presence of pp65 antigen in the PMN nuclei is a reflection of recent antigen uptake at vascular endothelial sites of CMV replication $[50,105]$. The relative overproduction of pp65 protein and its strong nuclear localization signal are responsible for this phenomenon. As pp65 belongs to the delayed early class of CMV antigens [50,51], its presence in PMNs may reflect early stages of infection in the host, which makes it a suitable marker for early diagnosis. This fact, on the other hand, may also lead to positive antigenemia results in patients not developing a systemic productive (abortive) infection [30]. Consequently, low levels of pp65-positive PMN can be found in patients with a subclinical infection.

Futhermore, in solid organ transplant recipients with primary CMV infection, it has been reported that relatively high levels (>10 pp65 positive cells per 100000 PMNs) may persist or that levels even increase upon successful antiviral intervention [46]. In addition, a considerable number of modifications concerning every step in the protocol have been introduced in different laboratories, among them: the method used for the isolation of PMNs, the number of cells used for preparing slides, the use of different fixation methods, the use of different monoclonal antibodies and chromogenic versus fluorescent detection of positive cells, the use of different methods for scoring the number of positive cells $[5,33,45,64,104,149]$. Although introduction of these modifications was intended to improve the performance of the original assay, it resulted in substantial interlaboratory variations [130]. Nevertheless, its high diagnostic accuracy, rapidity and technical simplicity have made the CMV antigenemia assay one of the cornerstone methods for the diagnosis and management of active CMV infection in non-leukopenic immune compromised patients [11, 44, 128, 129, 137].

In our laboratory (chapter 3), the antigenemia assay is a common method used in renal transplant recipients. Therefore, we used the antigenemia assay as the 'golden standard' to compare with viral culture and with molecular diagnostic methods. The frequency of patients positive for the antigenemia assay was markedly different in renal transplant recipients (21-30\%) compared to liver transplant recipients $(68 \%)$. In renal transplant recipients, antigenemia was more frequently positive in primary $(65 \%)$ than in secondary infections $(18 \%)$. Also the maximal detected levels for antigenemia in renal transplant recipients were higher in primary than in secondary infections. In contrast, in liver transplant recipients, the frequency of antigenemia positivity and also the maximal detected levels for antigenemia were high in both primary and secondary CMV infections.

Our results confirm that in renal transplant recipients, severe CMV infection as reflected by high antigenemia peak values, is more or less restricted to high risk (CMV seronegative) transplant recipients that develop primary CMV infection after transplantation. In liver transplant recipients, severe CMV infection occurs more frequently and is present both in patients that were CMV seronegative before transplantation and in patients that were already CMV seropositive before transplantation. We also found a good correlation between the number of pp65-positive leukocytes and the clinical status of the recipient before and after treatment with ganciclovir.

\section{Molecular CMV diagnostic assays}

Transplant recipients with severe CMV infection and clinical symptoms are usually treated with antiviral drugs. However, antiviral treatment is most effective when treatment is initiated at an early stage of infection $[12,38,39,82]$. In general, molecular diagnostic assays are helpful for early detection of microorganisms. 
For several years, the following molecular diagnostic assays for qualitative detection of CMV DNA and CMV mRNA have been available and will be discussed: i) detection of viral DNA by PCR, ii) detection of pp67 mRNA by NASBA, and iii) detection of IE1 mRNA by NASBA.

\section{PCR assays}

Detection of CMV DNA by dot-blot methods [120, 140] have been completely superseded by polymerase chain reaction (PCR) assays. With PCR it is possible to amplify low concentrations of DNA exponentially to levels which can easily be detected. This is achieved by repetitive cycles of denaturation of DNA, annealing of specific primers and DNA synthesis. Each of these steps requires a different temperature. Characteristic for this procedure is the use of the enzyme Taq DNA polymerase which can withstand the high temperature used for denaturation of DNA. PCR was found to be a very sensitive assay for the detection of CMV DNA. However, most PCR methods are not standardized, which makes it difficult to compare the different studies in which the diagnostic value of PCR was evaluated.

Detection of CMV DNA does not always predict the onset of symptomatic infection, because DNA of latent virus can be detected as well $[32,44,151]$. Indeed, some authors have concluded that their nested PCR procedures do not provide prognostic information. In contrast, a non-nested PCR was found to produce good prognostic information in both transplant patients [67] and HIV-positive individuals [21]. The availability of fully quantitative PCR assays for CMV [42] offers, besides more detailed monitoring of transplant recipients, also further refining prognostic values and new insights in the pathogenesis of CMV infection.

Therefore, we investigated the usefulness of early detection of CMV DNA using a commercially available PCR test (BioSource, Etten-Leur, The Netherlands) with primers specific for a 254-bp amplicon in a conserved part of the CMV gB region. The number of samples that were positive in the PCR (49 out of 291) was higher compared to the number of samples positive for antigenemia (33) and viral culture (26). In addition, the number of renal transplant recipients positive for PCR (13 out of 30) was higher compared to the number of patients positive for antigenemia (9) and viral culture (10). Compared to antigenemia, the sensitivity, specificity, positive predictive value and negative predictive value of PCR were respectively 100, 81, 69 and 100\%. Within our group of renal transplant recipients, PCR detected all the (high) risk recipients. These findings were in agreement with other results obtained with the same CMV DNA detection method [101]. However, a considerable number of samples and recipients were positive for other tests but negative for PCR. That was probably also the reason why the manufacturer modified the method afterwards by lowering the number of added copies of the internal calibration standard and increasing the number of cycles. With this modified method, samples containing at least 3 copies per amplification $(600$ copies $/ \mathrm{ml})$ were detectable [101].

Although CMV is mainly a cell-associated virus, CMV-DNA can also be detected in cell-free body fluids, such as serum and plasma $[2,26,121]$. There is still an ongoing discussion whether to use serum or plasma samples, leukocyte samples or whole blood samples. In general, whole blood and leukocyte-based assays are more sensitive than the plasma-based assays. There is also a trend for earlier CMV positivity after transplantation and more rapid negativity after initiation of ganciclovir therapy for the tests performed on leukocytes [16]. The detection of viral DNA in whole blood appeared to be a good marker for monitoring the effect of antiviral therapy in both bone marrow transplant recipients [36] and solid organ transplant recipients [136]. From a technical point of view, the use of plasma has an advantage over the use of leukocytes in PCR [133]. Plasma PCR is easier to perform and plasma offers the benefit of easier specimen processing and handling; moreover, it is possible to detect CMV in neutropenic patients [57]. In addition, the detection of viral DNA in serum 
and plasma of solid organ transplant recipients appears to correlate better with symptomatic CMV infection than detection of viral DNA in leukocytes, particularly in transplant recipients with secondary infections $[13,29,34,40,61]$. However, it was recently found that CMV DNA in plasma and serum is highly fragmented and does not necessarily reflect the amount of infectious virus [18]. These observations probably have important consequences for studying CMV pathogenesis and interpreting CMV DNA detection in individual patient management.

For daily clinical practice, a selection has to be made for one or few available assays that are easy to perform and give sufficient information about the virus and its replication in the patient. Recently, also in our laboratory, there is an ongoing trend towards the use of a quantitative CMV viral load in plasma for monitoring CMV infected patients.

\section{pp67 NASBA}

More than viral DNA and protein, the presence of CMV encoded mRNA in blood and/or in other specimens directly reflects viral biological activity. Previous studies addressing CMV RNA expression in blood have mainly used reverse transcriptase PCR, a procedure which is rather tedious and complicated by the presence of viral DNA, limiting its use mainly to the analysis of spliced genes $[6$, $7,15,49,72,84,90,139]$ in research settings and mostly not in the diagnostic laboratory.

The first commercially available, internally controlled and standardized mRNA assay was the pp67 NASBA assay. It detects the true late mRNA, which codes for the matrix tegument protein pp67 of CMV, and is transcribed from the UL65 gene [27]. This gene is only expressed during an episode of active infection, when there is actual virus replication. The practical advantages of the pp67 NASBA assay are: same day results, sample stability in lysis buffer allowing shipment, storage and re-testing, minimum patient sample volume required (100 microliter) which makes the assay also suitable for pediatric use, the possibility to re-use remaining reagents twice within a two week period, the possibility to automate the isolation and the automated detection [87].

Besides these practical advantages, in our hands as described in chapter 2 and 3, pp67 NASBA was almost equivalent to viral culture and antigenemia for the detection of CMV in renal transplant recipients. Compared to antigenemia, in two groups of renal transplant recipients, the sensitivity, specificity, positive predictive value and negative predictive value of pp67 NASBA were $89-100 \%$, $81-88 \%, 67-69 \%$ and $94-100 \%$, respectively. Also the number of positive samples and recipients that were positive for pp67 NASBA, antigenemia or viral culture, were almost similar. Secondly, the distribution of the first day of positivity is similar for these three tests, with mean (and range) values of 42 (26-75), 40 (22-69) and 38 (23-69) for pp67 NASBA, antigenemia and viral culture, respectively. However, a positive result of the viral culture will always take an additional delay of 2 days (for DEAFF) to 6 weeks (for CPE) due to the required incubation time.

In liver transplant recipients, the correlation between pp67 NASBA and antigenemia was less pronounced. Compared to antigenemia, the sensitivity, specificity, positive predictive value and negative predictive value of pp67 NASBA was $71 \%, 88 \%, 92 \%$ and $58 \%$, respectively. In liver transplant recipients with primary infection, all 4 recipients were positive for both antigenemia and pp67 NASBA. In liver transplant recipients with secondary CMV infection, pp67 NASBA was less frequently positive (47\%) compared to antigenemia (68\%). In addition, in 6 liver transplant recipients treated with ganciclovir, some pp67 NASBA-negative samples were seen although the antigenemia was highly positive in these samples. 
In this way, and from an analytical point of view, the pp67 NASBA assay appeared not to be the most sensitive assay. On the other hand, various comparative studies showed that the assay had the best positive predictive value for CMV disease $[8,31,150]$. Latency and abortive or transient infection signals were not detected by the assay, while other assays could become positive in these stages of CMV infection [87]. In addition, since mRNA has a very short half-life in vivo, pp67 mRNA disappears rapidly as antiviral drug therapy takes effect [87]. Therefore, and from a therapeutical point of view, pp67 NASBA is a very promising tool for monitoring the effect of antiviral treatment. Recently, also direct quantification of CMV pp67 mRNA in blood using competitive NASBA has been described [52].

\section{IE1 NASBA}

Differential analysis of CMV gene expression may provide a means to closely monitor relevant CMV activity in vivo. The expression of late pp67 mRNA in blood may be considered as a specific and direct marker of viral replication $[9,10,15,47,49,72,84,86,90,92]$. On the other hand, immediate early mRNA detection may reflect either early stages of disseminating infection or, alternatively, reflect abortive infection $[48,72,86,98,139]$.

Detection of IE1 mRNA expression by NASBA is very similar to the pp67-NASBA assay except for the primers that are directed to exon 4 of the immediate early gene. Therefore, the practical advantages of the pp67-NASBA assay are also true for the IE1-NASBA. In practice, the performance of IE1NASBA is based on the NucliSense Basic Kit (BioMérieux) in combination with specific IE1 primers [138].

In chapter 2 we compared the value of different diagnostic tests for early detection of CMV infection in renal transplant recipients. For this purpose the following tests were used: DNA detection by PCR, detection of immediate early 1 mRNA and pp67 mRNA by NASBA, detection of pp65 protein by antigenemia assay, and detection of CMV by culturing the virus on fibroblasts. We found that viral culture, pp65-antigenemia, and pp67 mRNA NASBA were comparable for detection of CMV in renal transplant recipients. Both the first day of detection, i.e. mean day 37, 38, and 41 respectively, and number of positive samples and positive patients were similar for viral culture, pp65-antigenemia, and pp67 NASBA.

Compared to these three tests, PCR performed better and detected CMV in more patients and in more samples. Also the first day of detection (mean day 35) was slightly earlier for PCR than for the other tests. However, PCR missed some recipients that were positive in other tests. IE1 NASBA was the most sensitive test and detected approximately $90 \%$ of all positive samples and positive patients. In most patients, IE1 NASBA preceded PCR and all other positive test results. Of 7 patients positive for all tests used, in six of these patients, IE1 NASBA was the first positive test, whereas, in one patient, the result of the positive conventional culture was obtained only after IE1 NASBA was already positive in the next samples. Fiftheen other patients were positive in one or more of the tests used, but were missed by at least one test. Within these 15 patients, IE1 NASBA was positive in 13 patients, and in each of these 13 patients, IE1 NASBA was always the first positive signal. This makes IE1 NASBA the first diagnostic clue for detection of $\mathrm{CMV}$ infection and permits intensified diagnostic investigation and, subsequently, early antiviral treatment. However, eighteen of 291 samples were positive only for IE1 NASBA. For 10 of these samples, the positive IE1 NASBA results were confirmed by positive PCR results in following samples. In 5 patients, only IE1 NASBA became positive, whereas all other tests remained negative during the first 2 month postoperatively. The relevance of these isolated positive IE1 NASBA results was not clear and became one of the aims of the following studies that were described in chapters 3 and 4 . 
In chapter 3 we focused on the diagnostic value of NASBA for the detection of CMV infection, not only in renal transplant recipients, but also in liver transplant recipients and compared these data with results obtained by other tests, among them antigenemia and antibody response. We found that, not only in renal transplant recipients, but also in liver transplant recipients, IE1 NASBA was the most sensitive test and detected $96 \%$ of the positive samples. With the high sensitivity and negative predictive value of IE1 NASBA, a negative result rules out a CMV infection.

Although IE1 NASBA has advantages compared to other tests, the significance of a positive IE1 NASBA result is not always clear. In both groups of renal and liver transplant recipients, a positive signal with IE1 NASBA was not always an indication of an active or symptomatic infection with CMV. The question was raised whether IE1 NASBA is perhaps too sensitive for practical use and detects too many asymptomatic or subclinical infections. Indeed, some IE1 NASBA results could not be confirmed by other tests. Therefore, as the clinical significance of some positive IE1 NASBA results is not clear, a positive IE1 NASBA should be used in combination with assays that are more specific for the detection of symptomatic CMV infection. Nevertheless, as representative for immediate early gene products, IE1 NASBA may provide more insight into the pathogenesis of CMVrelated immunopathology.

\section{RNA expression and CMV IgM serology}

We studied the relationship between specific CMV IgM antibodies and the expression of IE1 and pp67 mRNAs in renal transplant recipients. In the past, different formats have been used to detect CMV specific antibodies in blood of CMV infected subjects. These have included immune hemagglutination, latex agglutination, immunofluorescence, virus neutralization, radioimmunoassay, and enzymimmunoassays [123]. Antigenic substrate for these assays consists mostly of lysates of virus-infected cells. Variations in the relative amounts of viral antigens produced during growth and purification of the virus can result in a different stoichiometric composition of the viral antigens used in the various tests, leading to discordant results. As a result, recent efforts have been directed toward utilizing recombinant-derived CMV proteins as antigenic substrates in these assays. The use of recombinant antigens has proven of great value in dissecting the human immune response to CMV $[19,83,100]$. More recently, several reports have demonstrated the suitability of recombinant antigens as well as peptide fragments of CMV proteins in diagnostic assays of CMV-specific antibodies [71, $75,76,141]$.

However, because - per definition - antibody responses develop only after viral exposure, serology is usually a late diagnostic marker, only indirectly reflecting prior events (i.e. viral protein expression) during earlier stages of infection. In the immunocompromised host, however, these responses may be affected or obscured by immune suppression and blood transfusions, thus making serology a suboptimal tool for early diagnosis and monitoring.

For most viral infections, the detection of specific $\operatorname{IgM}$ antibodies has been somewhat problematic by lack of sensitivity and specificity $[25,115]$. Especially the introduction of hybridoma technology for the production of monoclonal antibodies has improved greatly serologic reagents for the diagnosis of viral infections [25], including the detection of human CMV specific IgM antibodies. Since 1982, radioimmunoassays for the detection of CMV-specific IgM antibodies have been developed [23, 53, $54,55,99]$. Unfortunately, the safety concerns surrounding the use of radioactive iodine have restricted the use of these assays. 
Current CMV-specific IgM utilizes an enzymimmunoassay format in most commercially available assays. Estimated sensitivity varies in different populations, but, overall, the sensitivity of the assays range between 50\% and 90\% in immunocompetent adults with acute CMV infection $[79,122]$. In an effort to increase their sensitivity, many modifications have resulted in increased sensitivity but at the cost of specificity. Therefore, CMV IgM serology has always been hampered by the fact that the correlation of results obtained with different commercial kits is poor, and contradictory results are obtained if a serum sample is tested with different kits $[79,80]$. The key serological targets for detection of CMV-specific IgM include both structural $[63,70,74,73,76]$, and nonstructural $[75,107$, $142,143]$ viral proteins. Antigenic materials composed of peptides or purified recombinant proteins produced through molecular biology offer an attractive alternative for the detection of CMV-specific $\operatorname{IgM}[63,69,77,79,96,107,108,142,143]$.

Previously in our lab, Kraat et al. [70] showed that during acute CMV infections predominantly IgM antibodies against pp150 and p38 are developed. The pp150 antigen stands for the UL32-encoded basic phosphoprotein (ppUL32) and the p38 antigen stands for the UL80a-encoded capsid assembly protein. Using NASBA for detection of IE1 mRNA expression and/or late pp67 mRNA expression, we found that the expression of CMV mRNAs was correlated with the presence of anti-p38 and antipp150 IgM antibodies (chapter 4). In patients without active CMV infection as indicated by persistently negative results for viral culture, antigenemia, IE1-NASBA and pp67-NASBA, anti-CMV IgM antibodies were not detected. Expression of late viral pp67 mRNA was correlated with the presence of infectious virus and a higher frequency of anti-p38 IgM antibodies compared with antipp150 IgM antibodies. In contrast, in recipients with only expression of IE1 mRNA and therefore without a productive infection, there was a higher frequency of anti-pp150 IgM antibodies compared with anti-p38 IgM antibodies. Otherwise, the presence of anti-p38 IgM antibodies (with or without anti-pp150 IgM) was highly predictive (16 out of 18 patients) for a productive CMV infection, whereas in patients positive for anti-pp150 IgM antibodies but negative for anti-p38 IgM antibodies, no productive CMV infection could be demonstrated. In this way, monitoring the IgM response to p38 and pp150 may be of value for diagnosis and prognosis of CMV infected transplant recipients.

\section{Onset and duration of IE1 mRNA expression}

In chapter 5 the IE1 mRNA expression in kidney transplant recipients was studied in more detail. Especially the onset and duration of IE1 mRNA expression was followed and was related to patient characteristics and immunosuppressive therapy. In addition, and for the first time as far as we know, attention was given to the expression of IE1 mRNA in different CMV glycoprotein B (gB) genotypes in a transplant setting.

Of 69 recipients, 58 (84\%) recipients became positive for CMV immediate early 1 (IE1) mRNA as detected by NASBA after transplantation. The median onset of IE1 expression started at day 22 after transplantation and continued for a median duration of 82 days. IE1 mRNA expression started significantly earlier in recipients that developed an active CMV infection $(p=0.001)$ and in mycophenolate mofetil (MMF) treated recipients $(\mathrm{p}=0.002)$. The duration of IE1 mRNA expression was significantly longer in recipients that previously had an early onset of IE1 mRNA expression $(p=0.001)$ and in recipients with an active CMV infection $(p=0.007)$. Remarkably, longer prednisolone intake was correlated with a significantly $(\mathrm{p}=0.02)$ shorter duration of IE1 expression compared to a longer duration of IE1 expression in recipients with only a short prednisolone intake. In recipients infected with glycoprotein $\mathrm{B}(\mathrm{gB})$ type $1 \mathrm{CMV}$ strains, the duration of IE1 expression was significantly $(\mathrm{p}=0.04)$ shorter compared to recipients infected with non-gB type $1 \mathrm{CMV}$ strains (64 versus 150 days). 
MMF is an immunosuppressive agent that exerts relatively selective antiproliferative effects on $\mathrm{T}$ and B lymphocytes and has been successfully introduced into clinical practice with evident benefits for renal transplant recipients. MMF treatment not only results in a reduction of the incidence of acute rejections but also leads to reduction of late allograft loss. MMF also prevents CMV-induced chronic graft dysfunction. Although various multicentre clinical MMF trials failed to show an increase of the overall incidence of CMV infection, it does appear that MMF increases the incidence of tissue invasive CMV disease [113]. Recently it was also reported that the onset of CMV infection could be detected significantly earlier in MMF treated patients [125]. In our study, we found a similar correlation between MMF therapy and early CMV detection as expressed by early IE1 mRNA expression. Although our results suggest that MMF treatment may induce differences in IE1 mRNA expession, the exact mechanism by which MMF plays a role in CMV infection remains unclear.

Our findings concerning the influence of prednisolone on the IE1 mRNA expression are surprisingly. A potential role of prednisolone intake in the IE1 mRNA expression was suggested by the fact that the median day of prednisolone stop coincidenced with the median day of disappearence of IE1 NASBA positivity. However, median values of the duration of IE1 mRNA expression indicated a correlation between longer prednisolone use and a decreased IE1 duration. This was confirmed by multivariate analysis revealing that prolonged prednisolone treatment was significantly associated with a shorter duration of IE1 mRNA expression.

In the current literature, there is little information available about the interaction of glucocorticoids and CMV mRNA expression in human blood cells. In vitro, pharmacological concentrations of glucocorticoids stimulate the synthesis of human CMV immediate early antigens in human embryonic lung cells [127], and in differentiated monocytes [78, 81]. In vivo, a protective effect of glucocorticoids against lethal CMV-induced disease was described, although only in glucocorticoid deficient mice [112]. Nevertheless, detailed information is available about the interaction between glucocorticoids and nuclear factor kappa B (NFkB) and also about the interaction between NFkB and IE1 mRNA expression. The expression of IE1 in human CMV is under the control of a strong transcriptional enhancer [20,131] referred to as the major immediate early (MIE) promoter-enhancer. The unusually strong activity of this MIE promoter-enhancer is due to the presence of multiple binding sites for cellular transcription factors, e.g. NFkB [65, 88, 97, 152]. However, NFkB activation is inhibited by corticosteroids $[1,4,114,147]$. This means that in CMV infected patients without prednisolone intake, NFkB can activate the MIE promoter-enhancer resulting in increased expression of IE1 mRNA. Otherwise, we hypothesize that in CMV infected patients with prednisolone intake, activation of the MIE promoter-enhancer by NFkB will be blocked resulting in a decreased expression of IE1 mRNA. This hypothesis is in agreement with two recent studies describing a reduced stimulation of the IE1/2 enhancer/promoter by specific inhibition of NFkB signalling [152] and an attractive anticytomegaloviral potential of NFkB blockade [153].

An interesting finding is that statistically significant differences in the duration of IE1 mRNA expression were found between patients that were infected with either gB1 CMV strains and those infected with non-gB1 CMV strains. Although no many data are available on strain difference, some studies have shown that gB1 CMV strain is associated with a lower mortality compared to infection with non-gB1 types $[17,43]$. Later on, this was confirmed by a significant predominance of gB type 2 in bone marrow transplant recipients with CMV disease [58, 148], but not in renal transplant recipients [148]. In patients with advanced human immunodeficiency virus disease, viremia caused by gB group $2 \mathrm{CMV}$ strains is associated with higher risk of CMV retinitis than viremia caused by other CMV $\mathrm{gB}$ groups [116]. Also a significant association of CMV gB type 3 and 4 with death from myelosuppression after marrow transplantation was found [135]. All these studies suggest that, at least in some groups of immunocompromised patients, there is a more favorable clinical outcome in $\mathrm{gB}$ type 1 infected patients and a higher risk for symptomatic CMV infection in patients infected with $\mathrm{gB}$ types 2,3 , or 4 . How gB contributes to these virulence differences is unknown but it has been mentioned that $\mathrm{gB}$ type $1 \mathrm{CMV}$ did not infect $\mathrm{T}$ lymphocytes whereas gB types 2 and 3 did [124]. 
Further in vitro studies on the $\mathrm{gB}$ glycoprotein indicate that the interaction of $\mathrm{gB}$ with a yet unidentified cellular receptor, is an important mechanism by which CMV alters cellular gene expression [118]. The onset and/or duration of CMV IE1 mRNA expression, and especially the precise role herein of $\mathrm{CMV} \mathrm{gB}$ types and of the immune suppressive regimen, has to be evaluated further.

\section{CMV seropositivity and CD4 cell response}

In chapter 6 we studied whether seropositivity for CMV and other herpesviruses (HSV-1 and HSV-2) influenced the CD4 cell response after successful initiation of highly active antiretroviral therapy (HAART) in HIV-1 infected patients. Combined antiretroviral therapy of HIV positive patients with reduced CD4 cell counts in blood dramatically reduces viral replication and results in an increase in both CD4 and CD8 lymphocytes in the blood [3, 66].

Our study demonstrated that the upward trend in CD4 cell counts differs significantly between CMV seropositive and CMV seronegative patients that respond to HAART with undetectable viral loads after 24 weeks. This difference was unrelated to other factors known to influence CD4-cell counts, such as HIV-related factors like antiretroviral drugs, base-line plasma viral load and CD4 cell count, as well as non-specific factors like age and gender [111, 146]. CMV seropositive subjects have a temporarily (mean 32 weeks; confidence interval: 1-94 weeks) but significant delay in CD4 cell response. The maximal difference in CD4 cell counts was noticed 76 weeks after the initiation of HAART. Although this difference disappeared gradually, the normalisation of CD4 cell numbers took significantly longer in CMV seropositive patients than in CMV seronegative patients. This is in agreement with the findings of Kovacs et al. [68] in infants who were born to HIV-1 infected women. In this study lower CD4 counts and CD4 percentages were temporarely i.e. until 15 months of age, found in CMV infected children compared to CMV uninfected children. In contrast with CMV, we found no differences in CD4 cell counts with regard to HSV-1 or HSV-2 serostatus.

The interaction between CMV and CD4 cells may occur at different levels in HIV infected individuals. Possible levels of interaction include at least 3 mechanisms: (i) induction of cell death, (ii) suppression of clonal expansion or lymphopoiesis in peripheral and primary lymphoid organs, and (iii) alteration in lymphocyte trafficking. In lymphocytes infected with CMV, only immediate early antigen expression and early antigen expression has been reported $[22,35,106]$ without production of infectious virus or direct cytopathogenicity. It is therefore unlikely that CD4 cell decline is a result of direct killing by CMV or by CMV-mediated lytic mechanisms. The second possible mechanism is a diminished CD4-lymphopoiesis by CMV. CMV infection could, by infecting stromal cells in the bone marrow, indirectly affect primitive myeloid progenitor cells [134] which may result in leukopenia [119] and a reduction in proliferative T-cell response [91]. The third, and possibly most important mechanism, is CMV induced reduction in recirculating lymphocytes. Lymphocytes stay in the circulatory blood for only 30 minutes and the blood lymphocyte pool contains only $2 \%$ of all lymphocytes in the body at any given time. For that reason, minute changes in the rate of re-entry of lymphocytes into the blood can easily result in dramatic changes in the number within each subset of lymphocytes in the blood [111]. The widespread presence of CMV antigens, unlike HSV, in various organs $[95,145]$ in HIV-1 infected individuals may sequester CD4-cells by several mechanisms [41, $62,85,110,119,132,144]$ until the level of cellular immunity is sufficient to control viral replication. This may explain the temporarily effect of CMV on CD4 cell restoration after initiation of HAART, as was found in our study. Regardless of the exact mechanism by which CMV alters CD4 cell restoration during HAART, our finding reinforces the objective of preventing CMV disease in HAART-treated patients through (pre-emptive) antiviral therapy. 


\section{General conclusions and directions for further study}

In conclusion, infection with human CMV is very common and primary infection is followed by a lifelong persistence of the virus in a latent state. Reactivation of CMV may occur especially in immunocompromised individuals, such as renal transplant recipients, liver transplant recipients and HIV-infected patients. Both primary infection and reactivation of CMV can be detected in blood using a variety of diagnostic assays, e.g. viral culture, antigenemia, serology, PCR and NASBA.

Ideally, a diagnostic assay, or a selected combination of diagnostic assays, should: i) allow to detect an infection with CMV as early as possible, and ii) discriminate between a non-productive CMV infection versus a productive CMV infection potentially evolving to a symptomatic CMV infection or CMV disease. This information is helpful for the clinician to decide whether a patient with a productive CMV infection ought to be treated, e.g. with antiviral drugs, as opposed to a patient with a non-productive CMV infection without need for antiviral treatment. In our hands, early detection of CMV infection and discrimination between non-productive and productive CMV infection was possible using a combination of two NASBA tests, e.g. the IE1 NASBA test with a high negative predictive value and the pp67 NASBA test with a high positive predictive value.

However, for daily clinical practice, economical aspects of medical care cannot be neglected. In general, our health care system is increasingly searching for an optimal balance between effect (e.g. diagnostic information) and costs. This may imply that in patients at risk for CMV infection, diagnostic means will be restricted to as minimal diagnostic assays as possible. Accordingly, in most clinical laboratories a trend for a restriction of CMV diagnostic measures to the quantitative CMV DNA PCR as single test in use is observed.

The results of this thesis contribute to the knowledge and application of diagnostic tests in daily clinical practice. In addition, in this thesis several areas for further study have been indicated. Among these the role of the gB strain type in the pathogenesis of CMV disease, for example in transplant recipients and in AIDS patients, is an important finding that merits further attention. Another important finding described in this thesis is the effect of mycophenolate and prednisone on the course of CMV infection. This should be further explored since both compounds are commonly used in the clinic. The main point in this thesis was the study of the clinical relevance of CMV mRNA detection in blood of transplant recipients. Although the importance of detection of both immediate early and late mRNA for diagnostic purposes are rather clear, no full explanation for the presence of IE1 mRNA in the absence of late mRNA has been found. Further research on this issue will give us more insight in the interaction between CMV and the immune system of the host, and thus in the pathogenesis of CMV disease. 


\section{References}

1. Almawi WY, Melemedjian OK. Negative regulation of nuclear factor-kappa B activation and function by glucocorticoids. J Molec Endocrin 2002; 28: 69-78.

2. Aspin MM, Gallez Hawkins GM, Giugni TD, Tegtmeier B, Lang DJ, Schmidt GM, Forman SJ, Zaia JA. Comparison of plasma PCR and bronchoalveolar lavage fluid culture for detection of cytomegalovirus infection in adult bone marrow transplant recipients. J Clin Microbiol 1994;32:2266-2269.

3. Autran B, Carcelain G, Li TS, Blanc C, Mathez D, Tubiana R, Katlama C, Debre P, Leibowitch J. Positive effects of combined antiretroviral therapy on CD4+ T cell homeostasis and function in advanced HIV disease. Science 1997, 277:112116

4. Barnes PJ. Molecules in focus: Nuclear Factor Kappa B. Int J Biochem Cell Biol 1997; 29: 867-870.

5. Bein G, Bitsch A, Hoye J, Kirchner H. The detection of human cytomegalovirus immediate early antigen in peripheral blood leucocytes. J Immunol Methods 1991;137:175-180.

6. Bitsch A, Kirchner H, Dennin R, Hoyer J, Fricke L, Steinhoff J, Sack K, Bein G. The long persistence of CMV DNA in the blood of renal transplant patients after recovery from CMV infection. Transplantation 1993;56:108-113.

7. Bitsch A, Kirchner H, Dupke R, Bein G. Cytomegalovirus transcripts in peripheral blood leukocytes of actively infected transplant patients detected by reverse transcription polymerase chain reaction. J Infect Dis 1993;167:740-743.

8. Blank BS, Meenhorst PL, Pauw W, Mulder JW, van Dijk WC, Smits PH, Roeles F, Middeldorp JM, Lange JM. Detection of late pp67-mRNA by NASBA in peripheral blood for the diagnosis of human cytomegalovirus disease in AIDS patients. J Clin Virol 2002;25:29-38.

9. Blok MJ, Goossens VJ, Vanherle SJV, Top B, Tacken N, Middeldorp JM, Christiaans MHL, van Hooff JP, Bruggeman CA. Diagnostic value of monitoring human cytomegalovirus (CMV) late pp67 mRNA expression in renal allograft recipients by nucleic acid sequence based amplification. J Clin Microbiol $1998 ; 36: 1341-1346$.

10. Blok MJ, Christiaans MHL, Goossens VJ, van Hooff JP, Sillekens P, Middeldorp JM, Bruggeman CA. Early detection of human cytomegalovirus infection after kidney transplantation by nucleic acid sequence-based amplification. Transplantation $1999 ; 67: 1274-1277$

11. Boeckh M, Bowden RA, Goodrich JM, Pettinger M, Meyers JD. Cytomegalovirus antigen detection in peripheral blood leukocytes after allogeneic marrow transplantation. Blood 1992;80:1358-1364.

12. Boeckh M, Gooley TA, Myerson D, Cunningham T, Schoch G, Bowden RA. Cytomegalovirus pp65 antigenemia-guided early treatment with ganciclovir versus ganciclovir at engraftment after allogeneic marrow transplantation: a randomized double-blind study. Blood 1996;88:4063-4071.

13. Boeckh M, Gallez Hawkins GM, Myerson D, Zaia JA, Bowden R. Plasma polymerase chain reaction for cytomegalovirus DNA after allogenic marrow transplantation: comparison with polymerase chain reaction using peripheral blood leukocytes, pp65 antigenemia, and viral culture. Transplantation 1997;64:108-113.

14. Boeckh M, Boivin G. Quantitation of cytomegalovirus: Methodologic aspects and clinical applications. Clin Microbiol Rev 1998;11:533-554.

15. Boivin G, Hanfield J, Toma E, Lalonde R, Bergeron MG. Expression of the late cytomegalovirus (CMV) pp150 transcript in leukocytes of AIDS patients is associated with high viral DNA load in leukocytes and the presence of CMV-DNA in plasma. J Infect Dis 1999;179:1101-1107.

16. Boivin G, Belanger R, Delage R, Beliveau C, Demers C, Goyette N, Roy J. Quantitative analysis of cytomegalovirus (CMV) viremia using the pp65 antigenemia assay and the COBAS AMPLICOR CMV MONITOR PCR test after blood and marrow allogeneic transplantation. J Clin Micrbiol 2000;38:4356-4360.

17. Bongarts A, von Laer D, Vogelberg C, Ebert K, Van Lunzen J, Garweg J, Vaith P, Hufert FT, Haller O, Meyer-Konig U. Glycoprotein B genotypes of human cytomegalovirus; distribution in HIV-infected patients. Scand J Infect Dis 1996; 28: 447-449. 
18. Boom R, Sol CJ, Schuurman T, Van Breda A, Weel JF, Beld M, Ten Berge IJ, Wertheim-Van Dillen PM, De Jong MD. Human cytomegalovirus DNA in plasma and serum specimens of renal transplant recipients is highly fragmented. J Clin Microbiol 2002;40:4105-4113.

19. Boppana SB, Pass RF, Britt WJ: Virus-specific antibody responses in mothers and their newborn infants with asymptomatic congenital cytomegalovirus infections. J Infect Dis 1993;167: 72-77.

20. Boshart M, Weber F, Jahn G, Dorsch-Hasler K, Fleckenstein B, Schaffner W. A very strong enhancer is located upstream of an immediate early gene of human cytomegalovirus. Cell 1985; 41: 521-530.

21. Bowen EF, Sabin CA, Wilson P, Griffiths PD, Davey CC, Johnson MA, Emery VC. Cytomegalovirus (CMV) viraemia detected by polymerase chain reaction identifies a group of HIV-positive patients at high risk of CMV disease. AIDS 1997;11:889-893.

22. Braun RW, Reiser HC. Replication of human cytomegalovirus in human peripheral blood T cells. J Virol 1986, 60:29-36.

23. Britt WJ, Vugler L. Antiviral antibody responses in mothers and their newborn infants with clinical and subclinical congenital cytomegalovirus infections. J Infect Dis 1989; 161:214-219.

24. Britt WJ, Alford CA. Cytomegalovirus. In: Fields BN, Knipe DM, Chanock RM, et al, eds. Fields Virology. $3^{\text {rd }}$ ed. Vol.2 New York: Raven Press 1996; 3:2493-2523.

25. Bryan JA. The serologic diagnosis of viral infection. An update. Arch Pathol Lab Med 1987;111:1015-1023.

26. Brytting $\mathrm{M}, \mathrm{Xu} \mathrm{W}$, Wahren $\mathrm{B}$, Sundqvist VA. Cytomegalovirus DNA detection in sera from patients with active cytomegalovirus infections. J Clin Microbiol 1992;30:1937-1941.

27. Chee MS, Bankier AT, Beck S, Bohni R, Brown CM, Cerny R, Horsnell T, Hutchison III CA, Kouzarides T, Martignetti JA, Preddie E, Satchwell SC, Tomkinson P, Weston KM, Barrell BG. Analysis of the protein-coding content of the sequence of human cytomegalovirus strain AD169. Current Topics in Microbiol Immunology 1990;154:126-169.

28. Cox F, Hughes WT. Fecal excretion of cytomegalovirus in disseminated cytomegalic inclusion disease. J Infect Dis 1974;129:732-736.

29. Cunningham R, Harris A, Frankton A, Irving W. Detection of cytomegalovirus using PCR in serum from renal transplant recipients. J Clin Pathol 1995;48:575-577.

30. De Gast GC, Boland GJ, Vlieger AM, de Weger RA, Verdonck LF, Zwaan FE, Jiwa NM. Abortive human cytomegalovirus infection in patients after allogeneic bone marrow transplantation. Bone Marrow Transplant 1992;9:221225

31. Degre M, Kristiansen KI, Rollag H, Holter E, Nordal KP. Detection of human cytomegalovirus (HCMV) pp67-mRNA and pp65 antigenemia in relation to development of clinical HCMV disease in renal transplant recipients. Clin Microbiol Infect 2001;7:254-260

32. Delgado R, Lumbreras C, Alba C, Pedraza MA, Otero JR, Gomez R, Moreno E, Noriega AR, Paya VC. Low predictive value of polymerase chain reaction for diagnosis of cytomegalovirus disease in liver transplant recipients. J Clin Microbiol 1992;30:1876-1878

33. Docke WD, Simon HU, Fietze E, Prosch S, Diener C, Reinke P, Stein H, Volk HD. Cytomegalovirus infection and common variable immunodeficiency (Letter). Lancet 1991;338:1597.

34. Eckart P, Brouard J, Vabret A, Freymuth F, Guillot M, Ryckelynck JP, Hurault de Ligny B. Detection of human cytomegalovirus in renal transplantation: comparison of four diagnostic methods: DNA in sera by polymerase chain reaction (PCR), DNA in leukocyte by PCR, pp65 leukocytic antigenemia, and viremia. Transplant Proc 1997;29:2387-2389.

35. Einhorn L, Ost A. Cytomegalovirus infection of human blood cells. J Infect Dis 1984, 149:207-214.

36. Einsele H, Steidle M, Vallbracht A, Saal JG, Ehninger G, Muller CA. Early occurrence of human cytomegalovirus infection after bone marrow transplantation as demonstrated by the polymerase chain reaction technique. Blood 1991;77:1104-1110

37. Einsele H, Ehninger G, Steidle M, Vallbracht A, Muller M, Schmidt H, Saal JG, Waller HD, Muller CA. Polymerase chain reaction to evaluate antiviral therapy for cytomegalovirus disease. Lancet 1991;338:1170-1172. 
38. Einsele H, Ehninger G, Hebart H, Wittkowski KM, Schuler U, Jahn G, Mackes P, Herter M, Klingebiel T, Loffler J et al. Polymerase chain reaction monitoring reduces the incidence of cytomegalovirus disease and the duration and side effects of antiviral therapy after bone marrow transplantation. Blood 1995;86:2815-2820.

39. Einsele H, Hebart H, Kauffmann-Schneider C, Sinzger C, Jahn G, Bader P, Klingebiel T, Dietz K, Loffler J, Bokemeyer C, Muller CA, Kanz L. Risk factors for treatment failures in patients receiving PCR-based preemptive therapy for CMV infection. Bone Marrow Transplant 2000;25:757-763.

40. Evans PC, Soin A, Wreghitt TG, Alexander GJ. Qualitative and semiquantitative polymerase chain reaction testing for cytomegalovirus DNA in serum allows prediction of CMV related disease in liver transplant recipients. J Clin Pathol 1998;51:914-921.

41. Fietze E, Prosch S, Reinke P, Stein J, Docke WD, Staffa G, Loning S, Devaux S, Emmrich F, von Baehr R. Cytomegalovirus infection in transplant recipients. The role of tumor necrosis factor. Transplantation 1994, 58:675-680.

42. Fox JC, Griffiths PD, Emery VC. Quantification of human cytomegalovirus DNA using the polymerase chain reaction. Journal of General Virology 1992;73:2405-2408.

43. Fries BC, Chou S, Boeckh M, Torok-Storb B. Frequency distribution of cytomegalovirus envelope glycoprotein genotypes in bone marrow transplant recipients. J Infect Dis 1994; 169: 769-774.

44. Gerna G, Zipeto D, Parea M, Revello MG, Silini E, Percivalle E, Zavattoni M, Grossi P, Milanesi G. Monitoring of human cytomegalovirus infections and ganciclovir treatment in heart transplant recipients by determination of viremia, antigenemia, and DNAemia. J Infect Dis 1991;164:488-498.

45. Gerna G, Revello MG, Percivalle E, Morini F. Comparison of different immunostaining techniques and monoclonal antibodies to the lower matrix phosphoprotein (Pp65) for optimal quantitation of human cytomegalovirus antigenemia. J Clin Microbiol 1992;30:1232-1237.

46. Gerna G, Zavattoni M, Percevalle E, Grossi P, Torsellini M, Revello MG. Rising levels of human cytomegalovirus (HCMV) antigenemia during initial antiviral treatment of solid organ transplant recipients with primary HCMV infection. J Clin Microbiol 1998;36,1113-1116.

47. Gerna G, Baldanti F, Middeldorp JM, Furione M, Zavattoni M, Lilleri D, Revello MG. Clinical significance of expression of human cytomegalovirus pp67 late transcript in heart, lung, and bone marrow transplant recipients as determined by nucleic acid sequence-based amplification. J Clin Microbiol 1999;37:902-911.

48. Gerna G, Baldanti F, Lilleri D, Parea M, Alessandrino E, Pagani A, Locatelli F, Middeldorp J, Revello MG. Human cytomegalovirus immediate-early mRNA detection by nucleic acid sequence-based amplification as a new parameter for preemptive therapy in bone marrow transplant recipients. J Clin Microbiol 2000;38:1845-1853.

49. Gozlan J, Salord JM, Chouaid C, Duvivier C, Picard O, Mejohas MC, Petit JC. Human cytomegalovirus (HCMV) late mRNA detection in peripheral blood of AIDS patients: diagnostic value for HCMV disease compared to those of viral culture and HCMV DNA detection. J Clin Microbiol $1993 ; 31: 1943-1945$.

50. Grefte A, van der Gun BTF, Schmolke S, van der Giesen M, van Son WJ, Plachter B, Jahn G, The TH. The lower matrix protein pp65 is the principal viral antigen present in peripheral blood leukocytes during active cytomegalovirus infection. $\mathrm{J}$ Gen Virol 1992;73:2923-2932.

51. Grefte A, Harmsen MC, van der Giesen M, Knollema S, van Son WJ, The TH. Presence of human cytomegalovirus immediate early mRNA but not ppUL83 (lower matrix protein pp65) mRNA in poly-morphonuclear and mononuclear leukocytes during active HCMV infection. J Gen Virol 1994;75:1989-1998.

52. Greijer AE, Verschuuren EA, Harmsen MC, Dekkers CA, Adriaanse HM, The TH, Middeldorp JM. Direct quantification of human cytomegalovirus immediate-early and late mRNA levels in blood of lung transplant recipients by nucleic acid sequence-based amplification. J Clin Microbiol 2001;39:251-259.

53. Griffiths PD. The presumptive diagnosis of primary cytomegalovirus infection in early pregnancy by means of a radioimmunoassay for specific IgM antibodies. Br J Obstet Gynaecol 1981;88:582-587.

54. Griffiths PD, Stagno S, Pass RF, Smith RJ, Alford CA. Congenital cytomegalovirus infection: diagnostic and prognostic significance of the detection of specific IgM antibodies in cord serum. Pediatrics 1982;69:544-549. 
55. Griffiths PD, Stagno S, Pass RF, Smith RJ, Alford CA. Infection with cytomegalovirus during pregnancy: specific IgM antibodies as a marker of recent primary infection. J Infect Dis 1982;145:647-653.

56. Griffiths PD, Panjwani DD, Stirk PR, Ball MG, Ganczakowski M, Blacklock HA, Prentice HG. Rapid diagnosis of cytomegalovirus infection in immunocompromised patients by detection of early antigen fluorescent foci. Lancet 1984 ; $2: 1242-1245$.

57. Grossi P, Minoli L, Percivalle E, Irish W, Vigano M, Gerna G. Clinical and virological monitoring of human cytomegalovirus infection in 294 heart transplant recipients. Transplantation 1995;59:847-851.

58. Hebart H, Greif M, Krause H, Kanz L, Jahn G, Muller CA, Einsele H. Interstrain variation of immediate early DNA sequences and glycoprotein B genotypes in cytomegalovirus clinical isolates. Med Microbiol Immunol (Berl) 1997; 186: $135-138$.

59. Ho M. Virological diagnosis and infections in cells and tissues. In: Cytomegalovirus: Biology and Infection (second edition). Plenum Medical Book Company 1991;2:75-99.

60. Hudson JB, Misra V, Mosmann TR. Cytomegalovirus infectivity: analysis of the phenomenon of centrifugal enhancement of infectivity. Virology 1976;72:235-243.

61. Humar A, Gregson D, Caliendo AM, McGeer A, Malkan G, Krajden M, Corey P, Greig P, Walmsley S, Levy G, Mazzulli T. Clinical utility of quantitative cytomegalovirus viral load determination for predicting cytomegalovirus disease in liver transplant recipients. Transplantation 1999;68:1305-1311.

62. Humbert M, Roux Lombard P, Cerrina J, Magnan A, Simonneau G, Dartevelle P, Galanaud P, Dayer JM, Emilie D. Soluble TNF receptors (TNF-sR55 and TNF-sR75) in lung allograft recipients displaying cytomegalovirus pneumonitis. Am J Respir Crit Care Med 1994, 149:1681-1685.

63. Jahn G, Scholl BC, Traupe B, Fleckestein B. The two major structural phosphoproteins (pp65 and pp150) of human cytomegalovirus and their antigenic properties. J Gen Virol 1987;68:1237-1337.

64. Jiwa NM, van de Rijke FM, Mulder A, van der Bij W, The TH, Rotbarth PH, Velzing J, van der Ploeg M, Raap AK. An improved immunochemical method for the detection of human cytomegalovirus antigens in peripheral blood leukocytes. Histochemistry 1989;91:345-349.

65. Kanekiyo M, Itoh N, Kawasaki A, Tanaka J, Nakanishi T, Tanaka K. Zinc-induced activation of the human cytomegalovirus major immediate-early promoter is mediated by metallothionein and nuclear factor-kappaB. Toxocol Appl Pharmacol 2001; 173: 146-153.

66. Kelleher AD, Carr A, Zaunders J, Cooper DA. Alterations in the immune response of human immunodeficiency virus (HIV)-infected subjects treated with an HIV-specific protease inhibitor, ritonavir. J Infect Dis 1996, 173:321-329.

67. Kidd IM, Fox JC, Pillay D, Charman H, Griffiths PD, Emery VC. Provision of prognostic information in immunocompromised patients by routine application of the polymerase chain reaction for cytomegalovirus. Transplantation 1993;56:867-871.

68. Kovacs A, Schluchter M, Easley K, Demmler G, Shearer W, La Russa P, Pitt J, Cooper E, Goldfarb J, Hodes D, Kattan M, McIntosh K. Cytomegalovirus infection and HIV-1 disease progression in infants born to HIV-1 infected women. Pediatric Pulmonary and Cardiovascular Complications of Vertically Transmitted HIV Infection Study Group. N Engl J Med 1999;341:77-84.

69. Kraat YJ, Stals S, Landini MP, Bruggeman CA: Cytomegalovirus IgM antibody detection. Comparison of five assays. New Microbiol 1993;16:297-307.

70. Kraat YJ, Stals FS, Christiaans MH, Lazzarotto T, Landini MP, Bruggeman CA. IgM antibody detection of ppUL80a and ppUL32 by immunoblotting: An early parameter for recurrent cytomegalovirus infection in renal transplant recipients. J Med Virol 1996;48:289-294.

71. Kropff B, Landini MP, Mach M. An ELISA using recombinant proteins for the detection of neutralizing antibodies against human cytomegalovirus. J Med Virol 1993;39:187-195.

72. Lam KMC, Oldenburg N, Khan MA, Gaylore V, Mikhail GW, Strouhal PD, Middeldorp JM, Banner N, Yacoub M. Significance of reverse transcription polymerase chain reaction in the detection of human cytomegalovirus gene transcripts in thoracic organ transplant recipients. J Heart-Lung Transplant 1998;17:555-565. 
73. Landini MP, Mirolo G, Baldassari B, La Placa M. Human immune response to cytomegalovirus structural proteins studied by immunoblotting. J Med Virol 1985;17:303-311.

74. Landini MP, Lazzarotto T, Ripalti A, Guan MX, La Placa M. Antibody response to recombinant lambda gt11 fusion proteins in cytomegalovirus infection. J Clin Microbiol 1989;27:2324-2327.

75. Landini MP, Guan MX, Jahn G, Lindenmeier W, Mach M, Ripalti A, Necker A, Lazzarotto T, Plachter B. Large scale screening of human sera with cytomegalovirus recombinant antigens. J Clin Microbiol 1990;28:1375-1379.

76. Landini MP, Ripalti A, Sra K, Pouletty P. Human cytomegalovirus structural proteins: immune reaction against pp 150 synthetic peptides. J Clin Microbiol 1991;29:1868-1872.

77. Landini MP. Antibody responses to human cytomegalovirus proteins. Rev Med Virol 1992;2:63-72.

78. Lathey JL, Spector SA. Unrestricted replication of human cytomegalovirus in hydrocortisone-treated macrophages. J Virol 1991; 65: 6371-6375.

79. Lazzarotto T, Dalla Casa B, Campisi B, Landini MP. Enzyme-linked immunoadsorbent assay for the detection of cytomegalovirus-IgM: comparison between eight commercial kits, immunofluorescence and immunoblotting. J Clin Lab Anal 1992;6:216-218.

80. Lazzarotto T, Brojanac S, Maine GT, Landini MP. Search for cytomegalovirus-specific immunoglobulin M: Comparison between a new western blot, conventional western blot, and nine commercially available assays. Clin Diagn Lab Immunol $1997 ; 4: 483-486$

81. Lee CH, Lee GC, Chan YJ, Chiou CJ, Ahn JH, Hayward GS. Factors affecting human cytomegalovirus gene expression in human monocyte cell lines. Mol Cells 1999; 9: 37-44.

82. Ljungman P, Lore K, Aschan J, Klaesson S, Lewensohn-Fuchs I, Lonnqvist B, Ringden O, Winiarski J, Ehrnst A. Use of a semi-quantitative PCR for cytomegalovirus DNA as a basis for pre-emptive antiviral therapy in allogeneic bone marrow transplant patients. Bone Marrow Transplant 1996;17:583-587.

83. Marshall GS, Rabalais GP, Stout GG, Waldeyer SL. Antibodies to recombinant-derived glycoprotein B after natural human cytomegalovirus infection correlate with neutralizing activity. J Infect Dis 1992;165:381-384.

84. Meyer T, Reischl U, Wolf H, Schuller C, Arndt R. Identification of active cytomegalovirus infection by analysis of immediate early, early and late transcripts in peripheral blood cells of immunodeficient patients. Mol Cell Probes $1994 ; 8: 267-271$

85. Michelson S. Mechanisms of immunosuppression by human cytomegalovirus; in Doerr HW (ed): CMV-Related Immunopathology. Basel, Karger 1998, vol 21.

86. Middeldorp JM. Direct quantification of human cytomegalovirus (HCMV) immediate early and late mRNA levels in the blood of HCMV-infected individuals using competitive NASBA. J Clin Virol 1999;12:103

87. Middeldorp JM, Sillekens P, Lunenberg J. Diagnosis of active HCMV infection: the mRNA approach. Organs and Tissues 2000; 2:99-107.

88. Mocarski ES. Cytomegaloviruses and their replication. In: Fields BN, Knipe DM, Chanock RM, et al., eds. Fields Virology. $3^{\text {rd }}$ ed. Vol.2 New York: Raven Press 1996; 3: 2447-2492.

89. Monte PD, Lazzarotto T, Ripalti A, Landini MP. Human cytomegalovirus infection: a complex diagnostic problem in which molecular biology has induced a rapid evolution. Intervirology 1996;39:193-203.

90. Nelson PN, Kawal BK, Boriskin YS, Mathers KE, Powles RL, Steel HM, Tryhorn YS, Butcher PD, Booth JC. A polymerase chain reaction to detect a spliced late transcript of human cytomegalovirus in the blood of bone marrow transplant recipients. J Virol Meth 1996;56:139-148.

91. Odeberg J, Söderberg-Nauclér C. Reduced expression of HLA class II molecules and interleukin-10- and transforming growth factor beta1-independent suppression of T-cell proliferation in human cytomegalovirus-infected macrophage cultures. J Virol 2001, 75:5174-5181. 
92. Oldenburg N, Lam KM, Khan MA, Top B, Tacken NM, McKie A, Mikhail GW, Middeldorp JM, Wright A, Banner NR, Yacoub M. Evaluation of human cytomegalovirus gene expression in thoracic organ transplant recipients using nucleic acid sequence-based amplification. Transplantation 2000;70:1209-1215.

93. Osborne JE, Walker DL. Enhancement of infectivity of murine cytomegalovirus in vitro by centrifugal inoculation. J Virol 1968;2:853-858.

94. Patel R, Klein DW, Espy MJ, Harmsen WS, Ilstrup DM, Paya CV, Smith TF. Optimization of detection of cytomegalovirus viremia in transplantation recipients by shell vial assay. J Clin Microbiol 1995;33:2984-2986.

95. Pillay D, Lipman MC, Lee CA, Johnson MA, Griffiths PD, McLaughlin JE. A clinico-pathological audit of opportunistic viral infections in HIV-infected patients. AIDS 1993, 7:969-974.

96. Plachter B, Wieczorek L, Scholl BC, Ziegelmaier R, Jahn G. Detection of cytomegalovirus antibodies by an enzymelinked immunosorbent assay using recombinant polypeptides of the large phosphorylated tegument protein pp150. J Clin Microbiol 1992;30:201-206.

97. Prosch S, Staak K, Stein J, Liebenthal C, Stamminger T, Volk HD, Kruger DH. Stimulation of the human cytomegalovirus IE enhancer/promoter in HL-60 cells by TNF alpha is mediated via induction of NF-kappa B. Virology 1995; 208: 197-206.

98. Randhawa PS, Manez R, Frye B, Ehrlich GD. Circulating immediate-early mRNA in patients with cytomegalovirus infection after solid organ transplantation. J Infect Dis 1994;170:1264-1267.

99. Rasmussen L, Kelsall D, Nelson R, Carney W, Hirsch M, Winston D, Preiksaitis J, Merigan TC. Virus-specific IgG and IgM antibodies in normal and immunocompromised subjects infected with cytomegalovirus. J Infect Dis 1982;145:191-199.

100. Rasmussen L, Matkin C, Spaete R, Pachl C, Merigan TC. Antibody response to human cytomegalovirus glycoproteins $\mathrm{gB}$ and $\mathrm{gH}$ after natural infection in humans. J Infect Dis 1991;164:835-842.

101. Reagen KJ, Cabradilla C, Shuman B, Stollar N, Laudemann J, Bai X, Hosler G, Scheuermann RH. Analytical performance of a quantitative CMV DNA detection method. Monogr Virol. Basel, Karger, 1998; 21: 252-261.

102. Reina J, Saurina J, Fernandez-Baca V, Blanco I, Munar M. An increase in the number of polymorphonuclear leukocytes inoculated on shell-vial culture increases the sensitivity of this assay in the detection of cytomegalovirus in the blood of immunocompromised patients. Diagn Microbiol Infect Dis 1998;31:425-428.

103. Reusser P. Oral valganciclovir: a new option for treatment of cytomegalovirus infection and disease in immunocompromised hosts. Expert Opin Investig Drugs 2001;10:1745-1753.

104. Revello MG, Percivalle E, Zavattoni M, Parea M, Grossi P, Gerna G. Detection of human cytomegalovirus immediate early antigen in leukocytes as a marker of viremia in immunocompromised patients. J Med Virol 1989;29:88-93.

105. Revello MG, Percivalle E, Arbustini E, Pardi R, Sozzani S, Gerna G. In vitro generation of human cytomegalovirus pp65 antigenemia, viremia and leukoDNAemia. J Clin Invest 1998;101,2686-2692.

106. Rice GP, Schrier RD, Oldstone MB. Cytomegalovirus infects human lymphocytes and monocytes: virus expression is restricted to immediate-early gene products. Proc Natl Acad Sci USA 1984, 81:6134-6138.

107. Ripalti A, Dal Monte P, Boccuni MC, Campanini F, Bergamini G, Lazzarotto T, Campisi B, Ruan Q, Landini MP. Prokaryotic expression of a large fragment of the most antigenic cytomegalovirus DNA-binding protein (ppUL44) and its reactivity with human antibodies. J Virol Methods 1994;46:39-50.

108. Ripalti A, Ruan Q, Boccuni C, Campanini F, Bergamini G, Landini MP. Construction of polypeptide fusion antigens of human cytomegalovirus ppUL32: Reactivity with human antibodies. J Clin Microbiol 1994;32:358-363.

109. Roberts TC, Buller RS, Gaudreault-Keener M, Sternhell KE, Garlock K, Singer GG, Brennan DC, Storch GA. Effects of storage temperature and time on qualitative and quantitative detection of cytomegalovirus in blood specimens by shell vial culture and PCR. J Clin Microbiol 1997;35:2224-2228.

110. Rosenberg YJ, Cafaro A, Brennan T, Greenhouse JG, Villinger F, Ansari AA, Brown C, McKinnon K, Bellah S, YalleyOgunro J, Elkins WR, Gartner S, Lewis MG. Virus-induced cytokines regulate circulating lymphocyte levels during primary SIV infections. Int. Immunol 1997, 9:703-712. 
111. Rosenberg YJ, Anderson AO, Pabst R. HIV-induced decline in blood CD4/CD8 ratios: viral killing or altered lymphocyte trafficking? Immunology Today 1998, 19:10-17.

112. Ruzek MC, Pearce BD, Miller AH, Biron CA. Endogenous glucocorticoids protect against cytokine-mediated lethality during viral infection. J Immunol 1999; 162: 3527-3533.

113. Sarmiento JM, Dockrell DH, Schwab TR, Munn SR, Paya CV. Mycophenolate mofetil increases cytomegalovirus invasive organ disease in renal transplant patients. Clin Transplant 2000; 14: 136-138.

114. Scheinman R, Cogswell P, Lofquist A, Baldwin A. Role of transcriptional activation of 1 kappa B alpha in mediation of immunosuppression by glucocorticoids. Science 1995; 270: 283-286.

115. Schmidt NJ. Rapid viral diagnosis. Med Clin North Am 1983;67:953-972.

116. Shepp DH, Match ME, Ashraf AB, Lipson SM, Millan C, Pergolizzi R. Cytomegalovirus glycoprotein B groups associated with retinitis in AIDS. J Infect Dis 1996; 174: 184-187.

117. Shuster EA, Beneke JS, Tegtmeier GE, Pearson GR, Gleaves CA, Wold AD, Smith TF. Monoclonal antibody for rapid laboratory detection of cytomegalovirus infections : Characterization and diagnostic application. Mayo Clinic Proc 1985; 60:577-585.

118. Simmen KA, Singh J, Luukkonen BGM, Lopper M, Bittner A, Miller NE, Jackson MR, Compton T, Fruh K. Global modulation of cellular transcription by human cytomegalovirus is initiated by viral glycoprotein B. Proc Natl Acad Sci USA 2001; 98: 7140-7145.

119. Söderberg-Nauclér C, Fish KN, Nelson JA. Cytomegalovirus; in Chen SY, Rafi A (eds): Persistent viral infections. Chichester, Wiley 1999.

120. Spector SA, Spector DH. The use of DNA probes in studies of human cytomegalovirus. Clin Chem 1985;31:1514-1520.

121. Spector SA, Merrill R, Wolf D, Dankner WM. Detection of human cytomegalovirus in plasma of AIDS patients during acute visceral disease by DNA amplification. J Clin Microbiol 1992;30:2359-2365.

122. Stagno S, Tinker MK, Elrod C, Fuccillo D, Cloud G, O'Beirne AJ. Immunoglobulin M antibodies detected by enzymelinked immunosorbent assay and radioimmunoassay in the diagnosis of cytomegalovirus infections in pregnant women and newborn infants. J Clin Microbiol 1985;21:930-935.

123. Stagno S, Pass RF, Britt WJ: Cytomegalovirus. In: Schmidt NJ, Emmons RW, eds. Diagnostic procedures for viral, ricketsial and chlamydial infections. 6th ed. Washington, DC: American Public Health Association; 1989:321-378.

124. Sweet C. The pathogenicity of cytomegalovirus. FEMS Microbiology Reviews 1999; 23: 457-482.

125. Szymczakiewicz-Multanowska AM, Kuzniewski M, Zawilinska B, Zgorniak-Nowosielska I, Uracz D, Ignacak E, Betkowska-Prokop A, Sulowicz W. Factors influencing prevalence and clinical course of cytomegalovirus (CMV) infection in kidney transplant patients. Przegl Lek 2001; 58: 772-777.

126. Tanabe K, Tokumoto T, Ishikawa N, Koyama I, Takahashi K, Fuchinoue S, Kawai T, Koga S, Yagisawa T, Toma H, Ota K, Nakajima H. Comparative study of cytomegalovirus (CMV) antigenemia assay, polymerase chain reaction, serology, and shell vial assay in the early diagnosis and monitoring of CMV infection after renal transplantation. Transplantation 1997;64:1721-1725

127. Tanaka J, Ogura T, Kamiya S, Sato H, Yoshie T, Ogura H, Hatano M. Enhanced replication of human cytomegalovirus in human fibroblasts treated with dexamethasone. J Gen Virol 1984; 65: 1759-1767.

128. The TH, van der Ploeg M, van den Berg AP, Vlieger AM, van der Giessen M, van Son WJ. Direct detection of cytomegalovirus in peripheral blood leukocytes - A review of the antigenemia assay and polymerase chain reaction. Transplantation 1992;54:193-198.

129. The TH, van den Berg AP, van Son WJ, Klompmaker IJ, Harmsen MC, van der Giessen M, Sloff MJ. Monitoring for cytomegalovirus after organ transplantation: A clinical perspective. Transplant Proc 1993;25(suppl 4):5-9.

130. The TH, van den Berg AP, Harmsen MC, van der Bij W, van Son W. The cytomegalovirus antigenemia assay: a plea for standardization. Scand J Infect Dis Suppl 1995;99:25-29. 
131. Thomsen DR, Stenberg RM, Goins WF, Stinski MF. Promoter-regulatory region of the major immediate early gene of human cytomegalovirus. Proc Natl Acad Sci USA 1984; 81: 659-663.

132. Tilg H, Vogel W, Aulitzky WE, Herold M, Konigsrainer A, Margreiter R, Huber C. Evaluation of cytokines and cytokine-induced secondary messages in sera of patients after liver transplantation. Transplantation 1990, 49:1074-1080.

133. Tong CY, Cuevas L, Williams H, Bakran A. Use of laboratory assays to predict cytomegalovirus disease in renal transplant recipients [published erratum in J Clin Microbiol 1999;37:881]. J Clin Microbiol 1998;36:2681-2685.

134. Torok-Storb B, Simmons P, Khaira D, Stachel D, Myerson D. Cytomegalovirus and marrow function. Ann Hematol $1992,64: 4128-4131$.

135. Torok-Storb B, Boeckh M, Hoy C, Leisenring W, Myerson D, Gooley T. Association of specific cytomegalovirus genotypes with death from myelosuppression after marrow transplantation. Blood 1997; 90: 2097-2102.

136. Toyoda M, Carlos JB, Galera A, Galfayan K, Zhang X, Sun Z, Czer LS, Jordan SC. Correlation of cytomegalovirus DNA levels with response to antiviral therapy in cardiac and renal allograft recipients. Transplantation 1997;63:957-963.

137. van den Berg AP, Klompmaker IJ, Haagsma EB, Scholten-Sampson A, Bijleveld CM, Schirm J, van der Giessen M, Slooff MJ, The TH. Antigenemia in the diagnosis and monitoring of active cytomegalovirus infection after liver transplantation. J Infect Dis 1991;164:265-270.

138. van der Bij W, Torensma R, van Son WJ, Anema J, Schirm J, Tegzess AM, The TH. Rapid immunodiagnosis of active cytomegalovirus infection by monoclonal antibody staining of blood leucocytes. J Med Virol 1988; 25:179-188.

139. Velsing J, Rothbarth PH, Kroes ACM, Quint WGV. Detection of cytomegalovirus mRNA and DNA encoding the immediate early gene in peripheral blood leukocytes from immunocompromised patients. J Med Virol 1994;42:164-169.

140. Vonsover A, Gotlieb-Stematsky T, Sayar Y, Bardov L, Manor Y, Siegal B. Detection of CMV in urine: comparison between DNA-DNA hybridization, virus isolation, and immunoelectron microscopy. J Virol Methods 1987;16:29-37.

141. Vornhagen R, Baur A, Jahn G, et al. Recombinant antigens in viral diagnostics. Bietr Infusionsther Tranfusionsmed 1992;30:78-81.

142. Vornhagen R, Plachter B, Hinderer W, The TH, Van Zanten J, Matter L, Schmidt CA, Sonneborn HH, Jahn G. Early serodiagnosis of acute human cytomegalovirus infection by enzyme-linked immunosorbent assay using recombinant antigens. J Clin Microbiol 1994; 32:981-986.

143. Vornhagen R, Hinderer W, Sonneborn HH, Bein G, Matter L, The TH, Jahn G, Plachter B. The DNA-binding protein pUL57 of human cytomegalovirus is a major target antigen for the immunoglobulin $\mathrm{M}$ antibody response during acute infection. J Clin Microbiol 1995;33:1927-1930.

144. Waldman WJ, Knight DA. Cytokine-mediated induction of endothelial adhesion molecule and histocompatibility leukocyte antigen expression by cytomegalovirus-activated T-cells. Am J Pathol 1996, 148:105-119.

145. Webster A, McLaughlin JE, Johnson MA, Emery VC, Griffiths PD. Use of the polymerase chain reaction to detect genomes of human immunodeficiency virus and cytomegalovirus in post-mortem tissues. J Med Virol 1995, 47:23-28.

146. Westermann J, Pabst R. Lymphocyte subsets in the blood: a diagnostic window on the lymphoid system? Immunol Today 1990, 11: 406-410.

147. Wissink S, van Heerde EC, van der Burg B, van der Saag PT. A dual mechanism mediates repression of NF-kappaB activity by glucocorticoids. Mol Endo 1998; 12: 355-363.

148. Woo PC, Lo CY, Lo SK, Siau H, Peiris JS, Wong SS, Luk WK, Chan TM, Lim WW, Yuen KY. Distinct genotype distributions of cytomegalovirus (CMV) envelope glycoprotein in bone marrow and renal transplant recipients with CMV disease. Clin Diagn Lab Immunol 1997; 4: 515-518.

149. Wunderli W, Kagi MK, Gruter E, Auracher JD. Detection of cytomegalovirus in peripheral leukocytes by different methods. J Clin Microbiol 1989;27:1916-1917.

150. Zhang F, Tetali S, Wang XP, Kaplan MH, Cromme FV, Ginocchio CC. Detection of cytomegalovirus pp67 late gene transcripts in cerebrospinal fluid of human immunodeficiency virus type 1-infected patients by nucleic acid sequence-based amplification. J Clin Microbiol 2000; 38:1920-1925. 
151. Zipeto D, Revello MG, Silini E, Parea M, Percivalle E, Zavattoni M, Milanesi G, Gerna G. Development and clinical significance of a diagnostic assay based on the polymerase chain reaction for detection of human cytomegalovirus DNA in blood samples from immunocompromised patients. J Clin Microbiol 1992;30:527-530.

152. Prosch S, Wuttke R, Kruger DH, Volk HD. NF-kappa B--a potential therapeutic target for inhibition of human cytomegalovirus (re)activation? Biol Chem 2002;383:1601-1609.

153. Caposio P, Di Nicola A, Riera L, Dreano M, Garotta G, Gribaudo G, Landolfo S. 2003. Inhibition of IKK2 activity inhibits human cytomegalovirus replication and virus-induced NF-kB activity. Abstract J.03 (p81) in the Abstract Book of the $9^{\text {th }}$ International Cytomegalovirus Workshop and $1^{\text {st }}$ International Betaherpesvirus Workshop May 20-25, 2003, Maastricht, the Netherlands. 


\section{SAMENVATTING}





\section{Samenvatting}

Cytomegalovirus (CMV) is het vijfde lid van een familie van (minstens) acht herpesvirussen die ziekte kunnen veroorzaken bij mensen. Net als de andere herpesvirussen blijft ook CMV, na een eerste besmetting, verder levenslang aanwezig in de gastheer. Infecties met dit virus komen veelvuldig voor. Wereldwijd is, afhankelijk van de gekozen regio, 60 tot meer dan 95\% van de bevolking geïnfecteerd met CMV. Infectie met CMV veroorzaakt nauwelijks of geen symptomen bij 'gezonde' personen, d.w.z. bij personen met een normale afweer tegen infecties. Heel anders is het bij personen met een verminderde afweer. Dit is o.a. het geval bij AIDS-patiënten en bij personen die, bijvoorbeeld omwille van een transplantatie, langdurig afweerremmende medicatie moeten innemen. Bij zulke personen kan een infectie met CMV wel leiden tot ernstige ziektebeelden met ontstekingsverschijnselen in longen, lever, darm, oog en hersenweefsel, eventueel zelfs met dodelijke afloop. Behandeling met specifieke antivirale middelen is mogelijk doch is enkel effectief als de behandeling vroegtijdig gestart wordt. Dit betekent dat het nodig is om de infectie vroegtijdig te detecteren. Vandaar dat het uiterst belangrijk is om te beschikken over laboratorium-onderzoeken die het mogelijk maken een infectie met CMV zo vroegtijdig mogelijk op te sporen.

In dit proefschrift hebben we dan ook bijzondere aandacht geschonken aan het vergelijken van een aantal laboratorium-bepalingen voor: i) het aantonen van levend, infectieus virus via viruskweek; ii) het aantonen van virus via detectie van (aanmaak van) virale bestanddelen, zoals viraal DNA, viraal RNA en/of virale eiwitten; iii) het aantonen van lichaamseigen antistoffen, specifiek gericht tegen CMV. Dit vergelijkend onderzoek werd uitgevoerd bij verschillende groepen van patiënten, namelijk bij patiënten met een getransplanteerde nier en bij patiënten met een getransplanteerde lever. Daarnaast deden we ook onderzoek naar het effect van CMV bij patiënten die geïnfecteerd waren met het humaan immunodeficientie virus (HIV).

De resultaten van deze studies zijn echter beter te begrijpen als we, zoals in hoofdstuk 1, voorafgaandelijk eerst ingaan op de historiek van CMV, de ontwikkeling van diagnostische testen, de opbouw van het virus en de algemene kenmerken van de virusreplicatie.

In de historiek van CMV is 1904 een belangrijke mijlpaal; in dat jaar namelijk werd voor het eerst de aanwezigheid van 'abnormale' cellen beschreven in de nieren, longen en lever van doodgeboren kinderen met syfilis. Bij microscopisch onderzoek werden deze abnormale cellen gekenmerkt door hun grootte en enkele bijzondere afwijkingen: insluitlichaampjes omgeven door heldere omkadering in de celkern. Tegenwoordig wordt dit beeld herkend als het typische microscopische beeld van cellen geïnfecteerd met CMV. In 1921 werd de term 'cytomegalia' voor het eerst als beschrijvende term gebruikt van dergelijke cellen met abnormale grootte. In 1926 werd, met behulp van filters met bijzonder kleine porieopeningen, voor het eerst aangetoond dat de verwekker een virus was. De kweek van het virus bleef echter lange tijd onmogelijk totdat in 1956, de isolatie van CMV via viruskweek, quasi gelijktijdig beschreven werd door 3 onafhankelijke groepen van Amerikaanse onderzoekers.

Aansluitend aan de isolatie van CMV volgde de ontwikkeling van serologische testen voor het opsporen van antistoffen tegen CMV. Met behulp van deze testen was het mogelijk om verschillende types antistoffen aan te tonen, o.a. IgM en IgG antistoffen. Door het gebruik van dergelijke serologische testen bleek al vlug dat infecties met CMV niet enkel voorkwamen bij doodgeboren kinderen, maar ook bij levendgeboren kinderen, bij jongeren en bij vele volwassenen. Hierbij werd het duidelijk dat, hoewel infecties met CMV blijkbaar zeer frequent zijn, deze infecties slechts zelden aanleiding geven tot symptomen en dat symptomatische infecties hoofdzakelijk bij personen met een verminderde afweer optreden. Tabel 3 van hoofdstuk 1 geeft een overzicht van de meest voorkomende ziektebeelden en aangetaste organen die voorkomen tengevolge van een (eventuele) CMV infectie. Een 
bijzonder illustratief voorbeeld is paus Johannes-Paulus II die het slachtoffer was van een moordaanslag op 13 mei 1981, en waarbij tijdens een dringende chirurgische ingreep o.a. de milt werd verwijderd. Bij de daaropvolgende bloedtransfusies raakte de paus besmet met CMV en ontwikkelde een - bijna fatale - infectie met CMV.

CMV is, net als de andere herpesvirussen, opgebouwd uit DNA omgeven door meerdere lagen, namelijk van binnen naar buiten toe achtereenvolgens: een eiwitkapsel (= capside) met een diameter van ongeveer 100 nanometer, een eiwitrijke matrix ( $=$ tegument) en een dubbellagige buitenmantel (= enveloppe). In deze enveloppe zijn dan nog virale eiwitten verankerd die naar buiten uitsteken (zie fig. 2 van hoofdstuk 1). Volledige viruspartikels hebben een grootte van 150 tot 200 nanometer. Het virale DNA bevat de genetische informatie die, via een tussenstap met aanmaak van mRNA, kan resulteren in de aanmaak van meer dan 200 verschillende virale eiwitten. De belangrijkste virale eiwitten die in deze thesis besproken worden zijn: het naar buiten uitstekende glycoproteine $\mathrm{B}(\mathrm{gB})$ dat verankerd is in de enveloppe, drie eiwitten van het tegument, namelijk pp65, pp67 en pp150, en het capsideeiwit pp38. In deze thesis gaat verder ook veel aandacht uit naar het immediate early 1 (IE1) mRNA dat codeert voor het IE1-eiwit. Dit IE1-eiwit heeft een belangrijke regulerende rol in de virusreplicatie.

Virusreplicatie gebeurt noodzakelijkerwijs in een gastheercel. Allereerst moet het virus dus in contact komen met een gastheercel en er in binnendringen. Zodra het virus de cel is binnengedrongen begint de virale replicatie. Deze replicatie kan onderverdeeld worden in drie fasen, achtereenvolgens: de 'immediate early' fase die ongeveer de eerste 4 uur na binnendringen van het virus in de cel in beslag neemt, aansluitend volgt de 'early' fase en vervolgens de 'late' fase die start ongeveer 24 uur na binnendringen van het virus in de cel. Het virale IE1 eiwit wordt als een van de eerst geproduceerde eiwitten aangemaakt in de immediate early fase en speelt een belangrijke regulerende rol in het verdere verloop van de virale replicatie. Laattijdig in de virusreplicatie wordt, via aanmaak van pp67 mRNA, ook het pp67 eiwit aangemaakt. In de geïnfecteerde cel is het in principe mogelijk om rechtstreeks alle gevormde eiwitten aan te tonen. Dit geldt dus ook voor het pp67 en het IE1-eiwit. Momenteel zijn er echter moleculair biologische amplificatie-technieken voor het opsporen van IE1 en/of pp67 mRNA beschikbaar. Deze technieken zijn veel gevoeliger dan de technieken voor rechtstreekse eiwit-detectie. In deze thesis is er dan ook voor gekozen om de virale replicatie te bestuderen gebruik makend van de gevoelige IE1 en pp67 mRNA technieken.

In hoofdstuk 2 en 3 beschrijven we onze bevindingen bij niertransplantatie- en bij levertransplantatie-patiënten. Bij deze patiënten gebruikten we een nieuwe RNA-amplificatiemethode, namelijk de NASBA (nucleic acid sequence based amplification) voor het opsporen van boodschapper of 'messenger' RNA's (mRNA). Twee mRNAs werden geselecteerd, namelijk het IE1 en het pp67 mRNA. De gekozen mRNAs zijn duidelijk verschillend waarbij het IE1 mRNA reeds aantoonbaar wordt in de allereerste fase van de virusreplicatie en het pp67 mRNA slechts laat in de replicatie verschijnt. We vergeleken de NASBA-resultaten van beide mRNAs met de resultaten van andere diagnostische testen, namelijk kweek, detectie van DNA en detectie van het virale pp65-eiwit.

In hoofdstuk 2 beschrijven we de resultaten van een follow-up studie van 2 maanden bij 30 opeenvolgende patiënten die een niertransplantatie ondergingen. In deze periode werden 291 bloedmonsters verzameld voor het aantonen van CMV-infectie met behulp van: i) viruskweek, ii) de aanwezigheid van het virale pp65 eiwit in granulocyten met behulp van de zogenaamde 'pp65-antigenemie' test, iii) de aanwezigheid van IE1 mRNA en/of pp67 mRNA in bloed met behulp van de NASBA, en iv) de detectie van CMV-DNA met behulp van de polymerase-ketting-reactie onderzoek (PCR). Uit dit onderzoek blijkt dat voor het aantonen van een CMV-infectie drie bepalingsmethoden erg vergelijkbaar waren. Bij de viruskweek, de pp65-antigenemie en de pp67-NASBA waren zowel het eerste positieve resultaat 
(respectievelijk gemiddeld op dag 37, 38 en 41 na transplantatie), het aantal positieve bloedmonsters $(26,33$ en 33$)$ alsook het aantal positieve patiënten (10, 9 en 12) quasi gelijk. In vergelijking hiermee was de PCR een gevoeliger test. Met deze test werden er meer positieve monsters (49) en meer positieve patiënten gevonden (13). In vergelijking met de drie andere testen werd de PCR bepaling ook iets vroeger positief, namelijk gemiddeld op dag 35 na transplantatie. De meest gevoelige test was echter de IE1-NASBA bepaling die positief bevonden werd in 66 monsters afkomstig van 25 patiënten. Bij 20 patiënten, waarbij naast IE1-NASBA ook andere testen positief waren, viel het eerste positieve IE1-NASBA resultaat ofwel op dezelfde dag, ofwel 3 tot 28 dagen eerder in vergelijking met het eerste positief resultaat van de andere testen. Bij 5 patiënten was enkel de IE1-NASBA positief in één of meerdere monsters zonder confirmatie door andere testen. Mede hierdoor was de klinische betekenis van een positief IE1-NASBA resultaat niet helemaal duidelijk.

In hoofdstuk 3 is verder onderzoek naar het belang en de bruikbaarheid van de IE1-NASBA, de pp67-NASBA en de pp65-antigenemie bij twee groepen niertransplantatie-patiënten (groep 1 met 42 patiënten en groep 2 met 30 patiënten ook reeds besproken in hoofdstuk 2) en één groep van 25 levertransplantatie-patiënten beschreven. In vergelijking met de antigenemie vonden we in de drie groepen patiënten voor pp67-NASBA een sensitiviteit van $87 \%$, specificiteit van $86 \%$, positief voorspellende waarde van $76 \%$ en negatief voorspellende waarde van $84 \%$. In beide groepen niertransplantatie-patiënten was er een grote overeenkomst in resultaten tussen pp67-NASBA, pp65-antigenemie en viruskweek. Voor deze drie testen werd het eerste positief resultaat gemiddeld bekomen op dag 41 na de transplantatie. In de praktijk echter waren de positieve resultaten van de viruskweek pas later beschikbaar gezien de cytopathologische effecten in de viruskweek slechts waarneembaar werden na een incubatie-duur variërend van 2 dagen tot 6 weken. In de groep levertransplantatie-patiënten echter was de correlatie tussen pp67-NASBA en de pp65-antigenemie test opvallend minder goed. Mogelijk hield dit verband met de verschillen tussen patiënten met niertransplantatie en patiënten met levertransplantatie voor wat betreft de graad van toegepaste immuunsuppressie (duidelijk meer uitgesproken bij levertransplantatie) en de frequentie van antivirale therapie (die hoger was bij patiënten met levertransplantatie). In overeenstemming met de eerdere bevinding bij niertransplantatie-patiënten bleek dat ook bij levertransplantatie-patiënten de IE1-NASBA de meest gevoelige test was. Hierbij leverde de IE1-NASBA niet alleen het grootst aantal positieve monsters en positieve patiënten op, maar ook was deze test in vrijwel alle gevallen als eerste positief. In vergelijking met de antigenemie vertoonde de IE1-NASBA een sensitiviteit van $100 \%$ alsook een negatieve voorspellende waarde van $100 \%$. Anderzijds, net zoals bij niertransplantatie-patiënten, vonden we ook bij een aantal levertransplantatiepatiënten positieve IE1-NASBA resultaten zonder verdere aanwijzingen voor een actieve infectie met CMV.

Globaal toonden de resultaten van hoofdstuk 2 en hoofdstuk 3 aan dat beide mRNA bepalingen bijzonder interessante doch verschillende informatie gaven. Zo was de IE1NASBA test niet alleen de meest gevoelige test, maar was het ook de test die als eerste positief werd tijdens het verloop van de CMV infectie. De opvallend hoge sensitiviteit en negatieve voorspellende waarde van de IE1-NASBA lieten toe om een infectie met CMV uit te sluiten in geval van een negatief IE1-NASBA resultaat. Een positief IE1-NASBA resultaat gaf echter geen informatie over de ernst van de infectie. Dit was wel mogelijk met behulp van de pp67-NASBA bepaling. De pp67-NASBA test bleef negatief indien de patiënt een nietproductieve infectie doormaakte. Een niet-productieve infectie betekent dat niet alle stappen van de virusreplicatie doorlopen worden zodat er geen nieuwe intacte viruspartikels worden aangemaakt. Een positieve pp67-NASBA test daarentegen wijst er op dat er wel nieuwe intacte viruspartikels gevormd worden en dat de infectie zich verder uitbreidt of kan uitbreiden. Deze combinatie kan volgens ons dan ook vergeleken worden met de interpretatie van verkeerslichten waarbij: i) groen overeenkomt met IE1 negatief en pp67 negatief en beschouwd kan worden als veilig, geen CMV gevaar, ii) oranje overeenkomt met IE1 positief en pp67 negatief en beschouwd kan worden als een sluimerende CMV-infectie waarbij 
waakzaamheid geboden is, iii) rood overeenkomt met IE1 positief en pp67 positief en beschouwd kan worden als een infectie met CMV in volle actie met gevaar voor ontwikkeling van CMV-ziekte.

In de volgende hoofdstukken onderzochten we of een aantal virus- en patiënt-gebonden factoren verband kunnen houden met het klinisch verloop van de CMV-infectie. In hoofdstuk 4 onderzochten we of er individuele verschillen zijn in de aanmaak van antistoffen gericht tegen specifieke virale eiwitten. Hiervoor bestudeerden we in 46 niertransplantatie-patiënten, de aanmaak van IgM-antistoffen tegen het CMV p38 eiwit en tegen het CMV pp150 eiwit en dit met behulp van 2 nieuwe 'in-huis' ontworpen ELISA-testen. Op basis van de resultaten van IE1-NASBA, pp67-NASBA, pp65-antigenemie en viruskweek werden de patiënten onderverdeeld in drie groepen, namelijk: i) groep I patiënten waarbij IE1 positief was naast tenminste 1 andere positieve test, ii) groep II patiënten waarbij IE1 positief was en alle andere testen negatief bleven, iii) groep III patiënten waarbij IE1 negatief was alsook alle andere testen negatief waren. We constateerden opvallende verschillen tussen groep I en groep II voor wat betreft aanwezigheid van IgM-antistoffen tegen p38 (100\% in groep I versus $50 \%$ in groep II) en aanwezigheid van IgM-antistoffen tegen pp 150 (17\% in groep I versus $83 \%$ in groep II). In groep III konden geen IgM-antistoffen aangetoond worden. Volgens deze resultaten was de aanwezigheid van IgM-antistoffen tegen p38 (met of zonder IgMantistoffen tegen pp150) in hoge mate voorspellend voor een productieve CMV-infectie. Anderzijds werd de combinatie van een positief resultaat voor IgM antistoffen tegen pp150 en een negatief resultaat voor IgM-antistoffen tegen p38, enkel waargenomen bij patiënten zonder een productieve CMV-infectie. Monitoring van CMV IgM-antistoffen tegen p38 en pp150 kan blijkbaar zowel diagnostische als prognostische waarde hebben bij patiënten met niertransplantatie.

In hoofdstuk 5 beschreven we de resultaten bekomen bij 69 patiënten die we volgden gedurende 12 maanden na niertransplantatie. In deze studie werd aandacht besteed aan het (eerste) tijdstip waarop IE1-mRNA positief werd en aan de duur van IE1-mRNA aanwezigheid in het bloed. Van deze 69 patiënten werden er 58 (84\%) patiënten positief voor IE1-NASBA gedurende de studie. De eerste dag waarop de IE1-test positief werd situeerde zich op dag 22 (mediaan waarde) na de transplantatie. IE1-mRNA werd significant vroeger positief in patiënten die behandeld werden met mycofenolaat mofetil $(\mathrm{p}=0.002)$ dan bij patiënten zonder behandeling met mycofenolaat mofetil. Dit was ook het geval bij patiënten die een productieve $\mathrm{CMV}$-infectie ontwikkelden $(\mathrm{p}=0.001)$. Deze bevinding kan belangrijk zijn gezien mycofenolaat mofetil een stof is die vaak gebruikt wordt bij (nier-) transplantatiepatiënten om de immuniteit (deels) te onderdrukken waardoor de kans op afstoting van het getransplanteerde orgaan vermindert. Globaal gezien bleek de duur van de IE1-mRNA positieve periode significant langer te zijn bij patiënten waarbij de IE1 reeds vroegtijdig positief werd $(\mathrm{p}=0.001)$ dan bij patiënten waarbij IE1-mRNA eerder laattijdig positief werd. Gelijkaardig was de duur van de IE1-mRNA positieve periode significant langer bij patiënten die een productieve CMV-infectie ontwikkelden $(\mathrm{p}=0.007)$ in vergelijking met patiënten zonder productieve CMV-infectie. Bijzonder opvallend was de bevinding dat bij patiënten die langdurig behandeld werden met prednisolon de duur van de IE1-positieve periode significant korter was $(\mathrm{p}=0.02)$ dan bij patiënten die slechts kortdurend behandeld werden met prednisolon. Een mogelijke verklaring hiervoor zou kunnen zijn dat prednisolon ervoor zorgt dat de activatie van de 'major immediate early promoter-enhancer' door NF-kappa B wordt afgeremd, wat op zijn beurt resulteert in een verminderde expressie en aanmaak van IE1mRNA. Gezien, net zoals mycofenolaat mofetil, ook prednisolon vaak gebruikt wordt bij transplantatie-patiënten, is aanvullend wetenschappelijk onderzoek zeker nog aangewezen.

Alhoewel CMV maar uit 1 type bestaat, zijn er binnen de CMV virusstammen die we bij patiënten kunnen isoleren, verdere onderverdelingen in subtypen mogelijk. Zulke onderverdeling is bijvoorbeeld beschreven op basis van de verschillende varianten van het virale glycoproteine-B $(\mathrm{gB})$. Het $\mathrm{gB}$-eiwit dat verankerd is in de enveloppe van het virus 
speelt een rol bij het binnendringen van het virus in de cel. Tenminste 4 verschillende subtypen op basis van $\mathrm{gB}$ eiwitten zijn er aangetoond: namelijk subtype gB1, gB2, gB3 en gB4. In hoofdstuk 5 onderzochten we of infecties met deze verschillende CMV subtypen (gB1 subtype versus niet-gB1 subtypen) gecorreleerd waren met verschillen in IE1-mRNA positiviteit. We constateerden dat IE1-mRNA minder lang aantoonbaar was in bloed van patiënten geïnfecteerd met CMV subtype gB1 (met een mediane duur van 64 dagen IE1mRNA positiviteit) dan bij patiënten geïnfecteerd met een niet-gB1 subtype (met een mediane duur van 150 dagen IE1-mRNA positiviteit). Ook bij multivariaat statistisch onderzoek was dit verschil significant $(\mathrm{p}=0.04)$. Deze bevinding kan klinisch belangrijk zijn in de mate dat, tenminste in bepaalde groepen van immuun-gecompromiteerde patiënten, infecties met CMV van het subtype gB1 in het algemeen milder kunnen verlopen en dat infecties met niet-gB1 subtypen ernstiger kunnen verlopen.

Naast het feit dat CMV invloed heeft op het beloop van het genezingsproces na een orgaantransplantatie zijn er ook aanwijzingen dat CMV van invloed kan zijn op het beloop van het ziekteproces na een HIV infectie. Het omgekeerde, namelijk een invloed van HIV op het beloop van een CMV infectie is algemeen bekend. In hoofdstuk 6 stelden we ons de vraag of deze interactie ook opgaat in de andere richting. Kan een infectie met CMV een HIV infectie ernstiger doen verlopen, m.a.w. heeft CMV een effect op HIV? We onderzochten dit bij 62 HIV-geïnfecteerde patiënten. Het onderzoek vond plaats na de start van een bijzonder effectieve vorm van therapie, bekend als 'highly active anti-retroviral therapy' of HAART. Tijdens HAART-behandeling was er bij vrijwel alle patiënten een (gedeeltelijk) herstel van de immunologische afweer waarneembaar. Dit herstel was gekenmerkt door o.a. een toename van het aantal CD4 cellen in het bloed. In ons onderzoek stelden wij vast dat dit herstel snel optrad bij patiënten zonder CMV-infectie. Zo was er, na 76 weken HAART-behandeling, bij HIV-patiënten zonder CMV-infectie een stijging van gemiddeld 264 CD4 cellen tot gemiddeld 598 CD4 cellen per microliter bloed. In tegenstelling hiermee was het herstel van de CD4 cellen na 76 weken HAART-behandeling opvallend traag bij HIV-patiënten met CMV-infectie, namelijk een stijging van gemiddeld 289 CD4 cellen tot (slechts) 435 CD4 cellen per microliter bloed. Na 76 weken werd het verschil terug progressief kleiner zodat na 124 weken HAART-behandeling de gemiddelde waardes voor CD4 cellen in bloed quasi gelijk werden in beide groepen. Dit verschil in snelheid van herstel van CD4 cellen in beide groepen patiënten is ook grafisch weergegeven in fig. 1a van hoofdstuk 6. Deze bevinding werpt een nieuw licht op het idee om bij CMV-seropositieve HIV-patiënten, specifieke antiCMV behandeling toe te voegen aan de HAART-behandeling. Dit in de hoop dat hierdoor ook een snel herstel van de CD4 cellen in bloed bekomen kan worden bij HIV-patiënten met CMV infectie. Vooraleer dit in de patiëntenzorg kan of zal worden toegepast, is echter zeker aanvullend onderzoek nog noodzakelijk.

Globaal gezien draagt deze thesis bij aan een betere kennis en gebruik van beschikbare CMVonderzoeken in de dagelijkse patiëntenzorg. We toonden aan dat gecombineerd gebruik van de IE1-NASBA en pp67-NASBA bepalingen de mogelijkheid bieden om: i) CMV-infecties vroegtijdig op te sporen en ii) tevens onderscheid te maken tussen enerzijds niet-productieve CMV-infecties, die waarschijnlijk klinisch niet zo belangrijk zijn en anderzijds de klinisch wel belangrijke productieve CMV-infecties waarbij behandeling met specifieke antivirale middelen noodzakelijk kan zijn. Daarnaast zijn in deze thesis, meerdere van de bevindingen bijzonder uitnodigend voor verder wetenschappelijk onderzoek met als uiteindelijk doel te komen tot een beter inzicht in de interactie tussen CMV en het afweersysteem van de gastheer en deze kennis toe te passen in de patiëntenzorg. 
DANKWOORD / ACKNOWLEDGMENTS 



\section{Dankwoord/Acknowledgments}

Net zoals het promotieboekje start met een historisch overzicht, wil ik ook dit dankwoord benaderen vanuit historisch overzicht. Allereerst dus dank aan mijn ouders die mij reeds als kind stimuleerden tot hobbies waarbij ik me de allereerste beginselen van biologie, genetica en infecties eigen maakte. Zowel 'zorgen voor' alsook 'hoe zit dat in mekaar' maakten toen reeds deel uit van de dagdagelijkse activiteiten.

Niet helemaal onverwacht resulteerde dit in een opleiding geneeskunde. Het is echter dankzij onze huisarts Dr. Jules Bouts, dat een en ander in een stroomversnelling geraakte. Mede op zijn advies werden, reeds tijdens de kandidatuursjaren, de zomervakanties besteed aan bacteriologisch vakantiewerk in het Centraal Laboratorium te Hasselt. Na een eerste 'faecale' zomer steeg het niveau tot 'urine' en uiteindelijk zelfs tot 'varia'. Min of meer tegelijkertijd raakte ik, in een keuzevak gegeven door professor Billiau van het Rega-Instituut Leuven, geboeid door het "mooie" van de immunologie. Zelfs een eerste schuchtere poging tot bijdrage aan de interferon-research binnen het Rega-Instutuut ontbrak niet. Dit alles moet wel zo bijzonder geweest zijn, dat een verdere specialisatie tot klinische biologie/medische microbiologie niet kon uitblijven. De opleiding klinisch biologie, waarvoor veel dank aan prof. Vandepitte, werd op bijzondere wijze gekruid door enerzijds het Yersinia-onderzoek onder begeleiding van prof. Georges Wauters (UCL) en dr. Robert Tauxe (CDC, Atlanta) en anderzijds het Torulopsis glabrata-proefschrift als onderdeel van de mycologie-kursus van prof. Charles de Vroey en dr. Danielle Swinne aan het Instituut voor Tropische Geneeskunde te Antwerpen.

Binnen het domein van de virologie, en meer bepaald voor het wetenschappelijk onderzoek binnen dit proefschrift, gaat mijn dank in de eerste plaats uit naar mijn promotor Prof. Dr. Cathrien Bruggeman. Beste Cathrien, naar mijn gevoel klikte er reeds iets tijdens onze allereerste kennismakings-gesprekken. De daaropvolgende aanstelling tot arts-microbioloog binnen een academische setting resulteerde in een niet-aflatende concurrentie-strijd tussen patientenzorg, onderwijs en wetenschappelijk onderzoek. Volgens een volksgezegde, en zelfs volgens de bijbel, kan je geen twee heren dienen. Toch mag ik met enige voldoening zeggen dat ik, weliswaar niet zonder moeite, enigzins de vaardigheid heb verkregen om, als het ware drie heren te dienen. Het dienen van de derde heer, t.t.z. het wetenschappelijk onderzoek, was echter niet mogelijk zonder me te spiegelen aan jou Cathrien en aan Ellen Stobberingh en Kees Vink. Met woord en daad hebben jullie mij begeleid en gemotiveerd om te komen tot dit proefschrift.

Verder is dit proefschrift zodanig gebaseerd op en verweven met patientenzorg, dat ik zeker ook mijn dank wil uitdrukken voor de aangename samenwerking met de nefrologen Prof. Dr. Johannes van Hooff en Dr. Maarten Christiaans, met de AIDS-behandelaren Dr. Gerrit Schreij, Dr. Siebe van der Geest en Dr. André van der Ven.

Als staflid aan promotie-onderzoek doen is sowieso ook altijd ten nadele van de andere stafleden en assistenten. Op een of andere manier blijken er toch altijd taken te zijn die door anderen moeten overgenomen worden. Dank dus aan alle huidige stafleden, o.a. Jan Jacobs, Marlea Slobbe, Annick Smismans, Frank van Tiel, Annelies Verbon en voormalige stafleden Henk Bruning en Jeroen Tjhie. Verder kwam heel wat tijd ter beschikking via de hulp van de voormalige assistenten Nico Meesen en Els De Brauwer, beide intussen reeds erkend als artsmicrobioloog, en momenteel nog in opleiding: Teysir Halaby, Jeroen Keijman en Kitty Linssen.

Bijzonder belangrijk is ook de hulp die ik gekregen heb van alle analisten en administratie van het virologie-diagnostiek lab. Ik denk hierbij o.a. aan: Anita van de Berg, Magdalena Garcia Perdomo, Annick Hermans, Selma Herngreen, Frank Heusschen, Ron Horbach, 
Martine Hulsbosch, Anita Jacobs, Maddy Kerckhoffs, Ella Klomp-Berens, Steve Lake, Vera van Melick, Judith Nelissen, Sikko Oosterhoff, Henk Pieters, Olga Reinders, Jozien Spits, Sabine Stevens, Jef Strijthaegen en Bart Wulms. Zonder jullie was het verzamelen en het geordend verwerken van duizenden monsters, letterlijk een monsterachtig werk, compleet onmogelijk geweest. De bijhorende NASBA-draak werd als het ware vertroeteld door Bieke Vanherle. Ik ben ook bijzonder blij dat Bieke, tesamen met Nicole Leyssens, graag het paranymf-schap op zich wilden nemen.

De voorbije jaren heb ik ook meegedraaid binnen de groep van virologie-research aangestuurd door Cathrien Bruggeman en Kees Vink. Dank aan alle research-medewerkers voor de tussentijdse discussie- en overlegmomenten. Bijzondere dank ook aan Rien Blok en aan de mensen van BioMérieux (toenmalig Organon Teknika) Peter Sillekens en Jaap Middeldorp voor de aangename samenwerking binnen heel het NASBA-gebeuren. Wil Mullers en Peter Terporten waren bijzonder behulpzaam bij de statistische verwerking van onderzoeksresultaten en Patrick Beisser en Martijn Kwaijtaal bij de grafische vormgeving van het promotie-boekje. Eveneens dank aan Albert Ramon voor zijn hulp in woord en daad.

Wat betreft secretariële ondersteuning heb ik in toenemende mate beroep kunnen doen op beschikbare tijd van Fia Claus-Hahn, José Curfs, Angèle Eerens-Heuts en Patricia ZubiaurLucassen. Ook de talrijke overleg-momenten met mijn promoter waren enkel mogelijk via het zoeken van vrije (?) momenten in Cathriens agenda.

Natuurlijk wil ik mijn familie, vrienden en bekenden niet vergeten die ieder op hun eigen manier, en vaak zonder het zelf te beseffen, een bijdrage aan dit proefschrift hebben geleverd. Hierbij reken ik zeker de vele actievelingen binnen het verenigingsleven die mij geholpen hebben om niet te verdrinken in deze thesis. Pingpong liet mij toe om 'uit te zweten' en muziek liet mij toe om 'uit te blazen'. Binnen mijn familie zijn het vooral Marleen, Geert en Pieter die mij op bijzondere wijze het vermogen bijbrachten tot relativering en prioritering. Daarnaast zijn zij ook een zodanig krachtige en bijzondere motor geweest, dat ik zonder hen dit werk nooit op deze wijze had kunnen voltooien.

Bijna aan het einde van dit nawoord gekomen wil ik niet nalaten om ook de beoordelingscommissie, samengesteld Prof. Dr. Cohen Tervaert (voorzitter) en Prof. Dr. Donckerwolcke, Dr. van de Geest, Prof. Dr. Goubau en Prof. Dr. Leunissen, te bedanken voor het lezen van dit proefschrift en hun positieve beoordeling ervan.

Tenslotte ook dank aan U, lezer van dit proefschrift, en voor de toekomst alle goeds aan allen. 


\section{CURRICULUM VITAE}





\section{Curriculum vitae}

Valère Goossens werd geboren op 25 augustus 1958 te Bree. Na het doorlopen van de middelbare school (afdeling Latijn-Wiskunde) aan het Heilig Kruiscollege te Maaseik (19701976), volgde hij de studie Geneeskunde aan de Katholieke Universiteit Leuven (1976-1983) en behaalde in juni 1983 de graad van doctor in de genees-, heel- en verloskunde. Aansluitend doorliep hij ook in Leuven de opleiding Klinische Biologie (1983-1988) waarbij 24 maanden opleiding in de Klinische Chemie onder leiding van Dr. W. Lissens, 6 maanden opleiding in de Hematologie onder leiding van Prof. Dr. R. Verwilghen, 6 maanden Microbiologie onder leiding van Dr. K. Van Den Abbeele (in de Sint-Michielskliniek te Brussel) en 24 maanden Microbiologie onder leiding van Prof. Dr. J. Vandepitte.

Tussentijds volgde hij ook nog de post-universitaire specialisatie Mycologie-cursus + proefschrift 'Vindplaatsen van Torulopsis glabrata' (eindbeoordeling: grote onderscheiding) tot het bekomen van de graad van 'Specialist in de Medische en Veterinaire Mycologie' aan het Instituut voor Tropische Ziekten te Antwerpen (1986) en de opleiding Nucleaire Geneeskunde in Vitro (1987-1988) resulterend in een 'RIA-erkenning'.

In de periode 1988-1996 was hij als 'klinisch-bioloog met RIA-erkenning' werkzaam als diensthoofd van de 'RIA-afdeling' in Labo Rigo te Maasmechelen/Genk. In deze periode droeg hij eraan bij om, binnen dit laboratorium, een kwaliteitssysteem uit te werken zodanig dat dit resulteerde in een van de allereerste Beltest-accreditaties voor medische laboratoria in België.

Sinds november 1996 maakt hij deel uit van de staf van de Afdeling Medische Microbiologie van het Academisch Ziekenhuis Maastricht (azM). Na een bijkomende opleiding in de virologie (waarvan 3 maanden in Maastricht onder leiding van Frank van Tiel en Cathrien Bruggeman en 3 maanden in Leiden onder leiding van Louis Kroes) behaalde hij de erkenning als 'arts-microbioloog' in Nederland. Naast onderwijs aan de faculteit der Geneeskunde en aan de faculteit der Gezondheidswetenschappen, opleiding van artsassistenten, is het zijn belangrijkste taak om als 'klinisch viroloog' bij te dragen aan de academische patiëntenzorg binnen het azM.

Gedurende deze periode, met inbegrip van avonden en weekends, verrichtte hij verder wetenschappelijk onderzoek binnen de onderzoekschool CARIM en binnen de vakgroep Medische Microbiologie van de Universiteit Maastricht onder begeleiding van Prof. Dr. Cathrien Bruggeman. Dit resulteerde in het proefschrift getiteld "Cytomegalovirus mRNA transcripts and anti-cytomegalovirus antibodies as markers of the balance between cytomegalovirus and host immunity".

Valère Goossens is sinds 1982 getrouwd met Marleen Sijbers. Samen met hun twee zonen, Geert ( $\left.{ }^{\circ} 1984\right)$ en Pieter $\left({ }^{\circ} 1986\right)$ wonen ze sinds 1990 in Zutendaal. 


\section{PUBLICATIONS}





\section{Publications (for this thesis and as first author)}

Goossens VJ, Christiaans MHL, Blok MJ, Terporten PHW, Sillekens P. Van Hooff JP, Bruggeman CA. Onset and duration of cytomegalovirus immediate early 1 mRNA expression in blood of renal transplant recipients. Journal of Medical Virology (in press)

Goossens VJ, Schreij G, van der Geest S, Van Leeuwen DM, Baas DC, Bruggeman CA, van der Ven AJ. A delay in CD4 cell response after initiation of highly active antiretroviral therapy is associated with the presence of anti-cytomegalovirus but not with anti-herpes simplex virus antibodies. AIDS. 2002;16(12):1682-4.

Goossens VJ, Vink C, Mullers W, Middeldorp JM, Bruggeman CA. Different profiles of cytomegalovirus RNA transcripts and anti-cytomegalovirus IgM antibodies in renal transplant recipients. J Clin Virol. 2001;23(1-2):87-95.

Goossens VJ, Blok MJ, Christiaans MH, Sillekens P, Middeldorp JM, Bruggeman CA. Early detection of cytomegalovirus in renal transplant recipients: comparison of PCR, NASBA, pp65 antigenemia, and viral culture. Transplant Proc. 2000;32(1):155-8.

Goossens VJ, Blok MJ, Christiaans MH, van Hooff JP, Sillekens P, Höckerstedt K, Lautenschlager I, Middeldorp JM, Bruggeman CA. Diagnostic value of nucleic-acid-sequence- based amplification for the detection of cytomegalovirus infection in renal and liver transplant recipients. Intervirology. 1999;42(56):373-81.

\section{Abstracts (for this thesis and as first author)}

Goossens VJ, Christiaans MHL, Blok MJ, Terporten PHW, Sillekens P, Van Hooff JP, Bruggeman CA. Onset and duration of cytomegalovirus immediate early 1 mRNA expression in blood of renal transplant recipients. $9^{\text {th }}$ International Cytomegalovirus Workshop May 20-25, 2003 in Maastricht. Abstract F.23 in Abstract book p64.

Goossens VJ, van Leeuwen DM, Baas DC, Bruggeman CA, van der Ven AJ. Bij HIV-1 patiënten is er, na aanvang van 'highly active antiretroviral therapy', een tijdelijke vertraging in de CD4-respons bij cytomegalovirusseropositieve patiënten. Najaarsvergadering NVMM, 15 November, 2001 te Utrecht. Abstract in Nederlands Tijdschrift voor Medische Microbiologie 2002;146:695.

Goossens VJ, van Leeuwen DM, Baas DC, Bruggeman CA, van der Ven A. Delay in CD4 cell response after initiation of HAART in HIV-1 seropositive subjects is associated with the presence of anticytomegalovirus IgG-antibodies. 41 ${ }^{\text {st }}$ ICAAC, December 16-19, 2001 Chicago, Illinois. Abstract 1893 in $41^{\text {st }}$ ICAAC Abstracts Book.

Goossens VJ, Blok MJ, Christiaans MHL, Sillekens P, Middeldorp JM, Bruggeman CA. Onset and duration of CMV IE1 mRNA expression in blood of renal transplant recipients. Winter Meeting of the ESCV January 11-13, 2001 in Gent, België. Abstract book p26.

Goossens VJ, Vink C, Mullers W, Kraat YJ, Blok MJ, Sillekens P, Middeldorp JM, Bruggeman CA. Detection of anti-cytomegalovirus IgM antibodies and cytomegalovirus mRNAs in kidney transplant recipients. European Virology 2000, September 17-21, 2000 at Glasgow, Scotland. Abstract P-033 in Journal of Clinical Virology 2000;18:71

Goossens VJ, Blok MJ, Christiaans MHL, Sillekens P, Middeldorp JM, Bruggeman CA. Early detection of cytomegalovirus in renal transplant recipients: comparison of PCR, NASBA, pp65-antigenemia 
and viral culture. $5^{\text {th }}$ Congress of the International Society for Organ Sharing. April 14-16, 1999 at Maastricht. Published in the book of abstracts.

Goossens V. Early detection of cytomegalovirus in renal transplant recipients: additional value of PCR and NASBA. 7th International Cytomegalovirus Workshop April 28-May 1, 1999 at Brighton, UK. Abstract G016 in Journal of Clinical Virology 1999;12:100.

Goossens VJ. Comparison of PCR, antigenemia and viral culture for early detection of CMV infection in renal transplant recipients. Progress in Clinical Virology IV, $2^{\text {nd }}$ European Congress on Clinical Virology (ESCV), August 30-September 02, 1998 at Hamburg, Germany. Abstract K160 in Abstract Book.

\section{Publications (other)}

van Duijnhoven EM, Christiaans MH, Boots JM, Goossens VJ, Undre NA, van Hooff JP. A late episode of post-transplant diabetes mellitus during active hepatitis $\mathrm{C}$ infection in a renal allograft recipient using tacrolimus. Am J Kidney Dis. 2002;40(1):195-201.

Gijsen AP, Land JA, Goossens VJ, Slobbe ME, Bruggeman CA. Chlamydia antibody testing in screening for tubal factor subfertility: the significance of IgG antibody decline over time. Hum Reprod. 2002;17(3):699-703.

Schrander-Stumpel C, Goossens V, Koek G. Letter to the Editor: Hemofilie, hepatitis C en interferon alfa. Patient Care 2002;29:23.

Goossens VJ, van de Vusse AC. Letter to the Editor. Clin J Pain. 2001;17:378-9.

van de Vusse AC, Goossens VJ, Kemler MA, Weber WE. Screening of patients with complex regional pain syndrome for antecedent infections. Clin J Pain. 2001;17(2):110-4.

Gijsen AP, Land JA, Goossens VJ, Leffers P, Bruggeman CA, Evers JL. Chlamydia pneumoniae and screening for tubal factor subfertility. Hum Reprod. 2001;16(3):487-91.

Blok MJ, Lautenschlager I, Goossens VJ, Middeldorp JM, Vink C, Höckerstedt K, Bruggeman CA. Diagnostic implications of human cytomegalovirus immediate early-1 and pp67 mRNA detection in wholeblood samples from liver transplant patients using nucleic acid sequence-based amplification. J Clin Microbiol. 2000;38(12):4485-91.

Blok MJ, Lautenschlager I, Christiaans MH, Van Hooff JP, Goossens VJ, Middeldorp JM, Sillekens P, Höckerstedt K, Bruggeman CA. Sensitive detection of cytomegalovirus infection in transplant recipients using nucleic acid sequence-based amplification. Transplant Proc. 2000;32(1):149-51.

Blok MJ, Christiaans MH, Goossens VJ, van Hooff JP, Sillekens P, Middeldorp JM, Bruggeman CA. Early detection of human cytomegalovirus infection after kidney transplantation by nucleic acid sequencebased amplification. Transplantation. 1999;67(9):1274-7.

Blok MJ, Lautenschlager I, Christiaans MH, Van Hooff JP, Goossens VJ, Middeldorp JM, Sillekens P, Ramon A, Höckerstedt K, Bruggeman CA. Nucleic acid sequence-based amplification: a new technique for monitoring cytomegalovirus infection in transplant recipients. Transplant Proc. 1999;31(12):308-9.

Land JA, Evers JLH, Goossens VJ. Letter to the Editor: Chlamydia antibody titres. Hum Reprod. 1999;14(1):269-270. 
Blok MJ, Christiaans MH, Goossens VJ, van Hooff JP, Top B, Middeldorp JM, Bruggeman CA. Evaluation of a new method for early detection of active cytomegalovirus infections. A study in kidney transplant recipients. Transpl Int. 1998;11 Suppl 1:S107-9.

Land JA, Evers JL, Goossens VJ. How to use Chlamydia antibody testing in subfertility patients. Hum Reprod. 1998;13(4):1094-8.

Blok MJ, Goossens VJ, Vanherle SJ, Top B, Tacken N, Middeldorp JM, Christiaans MH, van Hooff JP, Bruggeman CA. Diagnostic value of monitoring human cytomegalovirus late pp67 mRNA expression in renal-allograft recipients by nucleic acid sequence-based amplification. $J$ Clin Microbiol. 1998;36(5):1341-6.

Goossens V, Vandepitte J, Lemmens P. Yersinia-leverabces: Gevalstudie en Literatuuroverzicht. Tijdschrift voor Gastro-Enterologie 1989;(20):3-14.

Wauters G, Goossens V, Janssens M, Vandepitte J. New enrichment method for isolation of pathogenic Yersinia enterocolitica serogroup O:3 from pork. Appl Environ Microbiol. 1988;54(4):851-4.

Goossens V, Gallant F, Ferdinande P, Lemmens P, Vandepitte J. Posttraumatische sepsis en meningitis door Yersinia enterocolitica. Tijdschrift voor Geneeskunde 1988;44:305-307.

Tauxe RV, Vandepitte J, Wauters G, Martin SM, Goossens V, De Mol P, Van Noyen R, Thiers G. Yersinia enterocolitica infections and pork: the missing link. Lancet. 1987;1(8542):1129-32.

\section{Abstracts (other)}

Van der Ven AJAM, Goossens VJ, van Leeuwen DM, Baas DC, Bruggeman CA. De toename van het aantal CD4 cellen is vertraagd na het succesvol starten van HAART bij HIV seropositieve patienten met anti-CMV IgG-antilichamen. Abstract in Nederlands Tijdschrift voor Geneeskunde 2001;145:1712.

Blok R, Lautenschlager I, Goossens VJ, Middeldorp JM, Vink C, Höckerstedt K, Bruggeman CA. Monitoring of HCMV IE1 and pp67 mRNA expression in liver transplant patients using NASBA. European Virology 2000, September 17-21, 2000 at Glasgow, Scotland. Abstact P-177 in Journal of Clinical Virology 2000;18:160

Gijsen AP, Goossens VJ, Land JA, Evers JLH, Bruggeman CA. The predictive value of Chlamydia antibody testing (CAT) in screening for tubal subfertility: micro-immunofluorescence (MIF) versus ELISA. Proceedings $4^{\text {th }}$ meeting of the European Society for Chlamydia Research 2000;4,101.

Gijsen AP, Land JA, Bruggeman CA, Goossens VJ, Evers JL. Chlamydia (C.) antibody testing (CAT) in screening for tubal factor subfertility: added value of determining C. pneumoniae antibodies? Annual Meeting of the American Society for Reproductive Medicine, September 25-30, 1999 at Toronto, Ontario, Canada. Abstract P-371 with citation in Fertility and Sterility 1999;72:S209.

Blok M, Goossens V, Ramon A, Sillekens P, Middeldorp J, Bruggeman C. Diagnostic value of NASBA for detection of cytomegalovirus (CMV) infection in renal and liver transplant recipients. ${ }^{\text {nd }}$ Symposium on CMV-related Immunopathology. September 17-18,1999 at Maastricht. Abstract 1 in Abstract Book.

Goossens VJ, Van de Vusse AC, Kemler MA, Weber WEJ. Screening of reflex sympathetic dystrophy (RSD) patients for antecedent infections. Thirth Annual Meeting of the ESCV September 1-5, 1999 at Budapest, Hungary. Abstract in Acta Microbiologica et Immunologica Hungarica 1999;46:400. 
Van de Vusse AC, Kemler MA, Goossens V, Weber WEJ. No evidence for an infectious cause of reflex sympathetic dystrophy. Peripheral Nerve Society Meeting, July 21-25, 1999 at San Diego, California. Abstract at http://pns.ucsd.edu/posta.abstracts.html\#vandeVusseAC.

Goossens VJ, Van de Vusse AC, Kemler MA, Weber WEJ. Is there an etiological role for infections in reflex sympathetic dystrophy? Voorjaarsvergadering NVMM, 20-21 April, 1999 te Veldhoven. Abstract P16 in Nederlands Tijdschrift voor Medische Microbiologie 1999;7:S41.

Goossens VJ, Luijckx GJ, De Baets M, Troost J. Guillain-Barré: deelgebied van neuroloog, immunoloog en microbioloog. Voorjaarsvergadering NVMM, 22-23 April, 1997 te Lunteren. Abstract C-6 in Nederlands Tijdschrift voor Medische Microbiologie 1997;5:S15.

Goossens V, Swinne D, De Vroey Ch, Vandepitte J. Oecology of Candida (Torulopsis) glabrata in hospitalized patients. Jaarlijkse Vergadering Belgische Vereniging voor Menselijke en Dierlijke Mycologie te Brugge, 19-20 september 1987. Abstract book p19-20.

\section{Thesis}

Goossens V. Vindplaatsen van Torulopsis glabrata: thesis tot het bekomen van de graad van 'Specialist in de Medische en Veterinaire Mycologie' aan het Instituut voor Tropische Ziekten te Antwerpen, 1986. 
FINALE 



\section{Virus in Zutendaal}
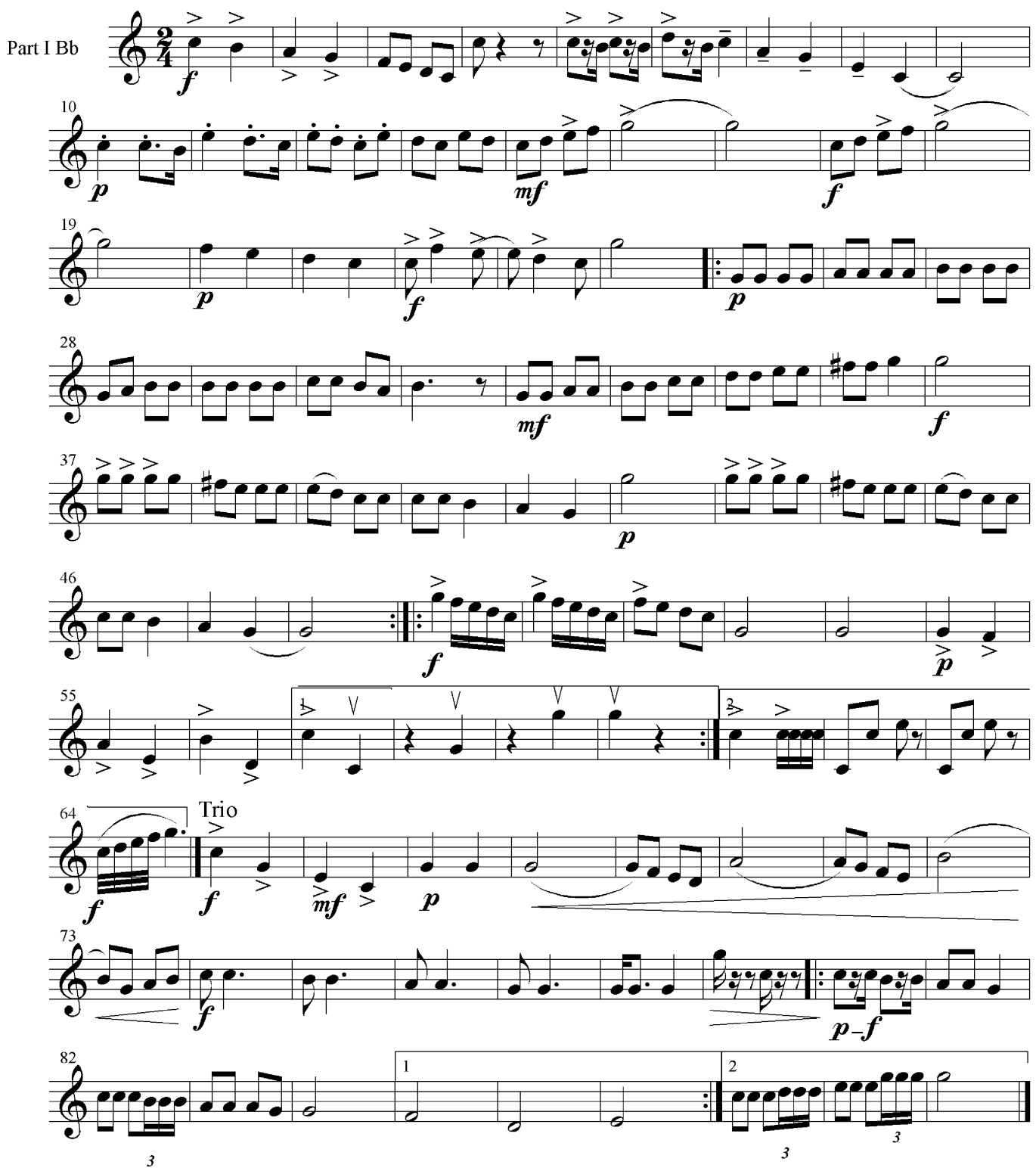
Virus in Zutendaal
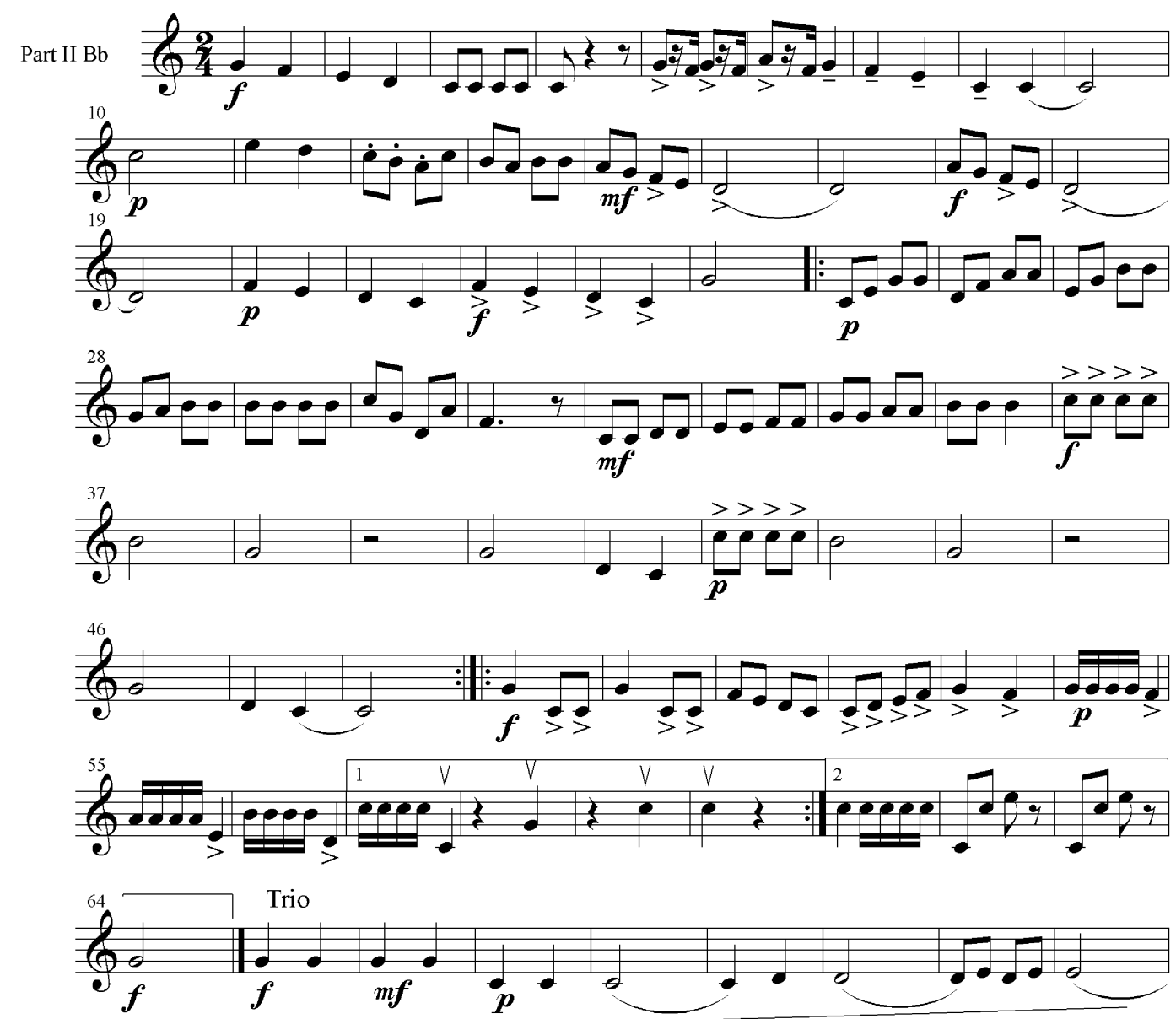

(6)

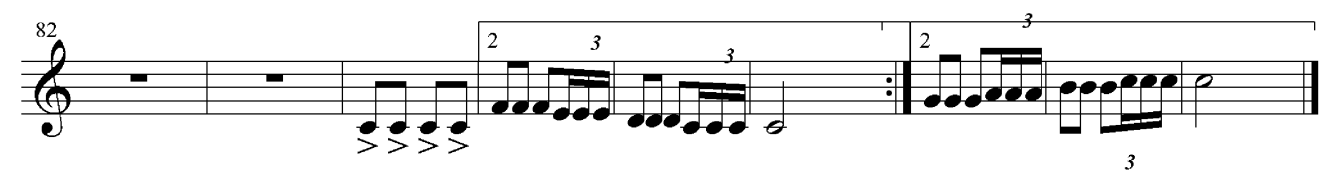


Virus in Zutendaal

Part III Bb

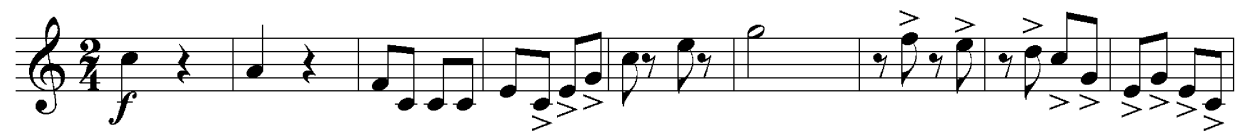

10
0

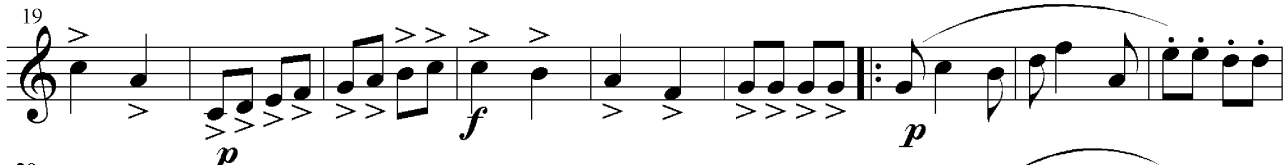

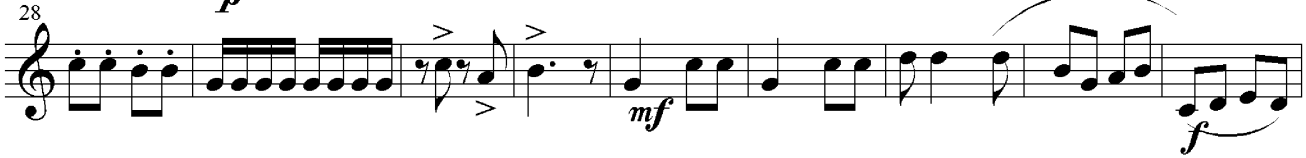

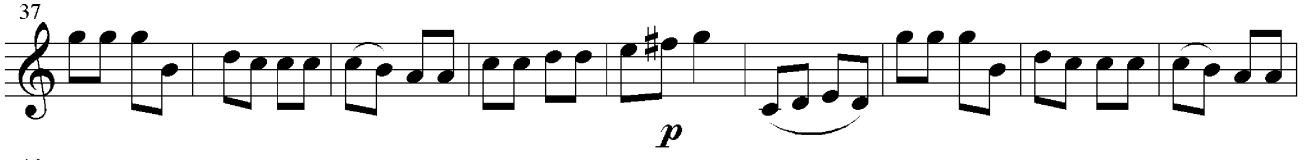

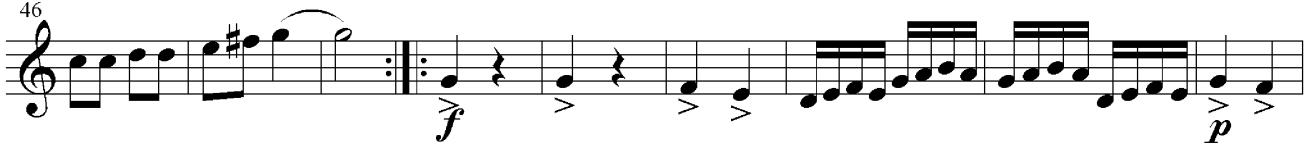

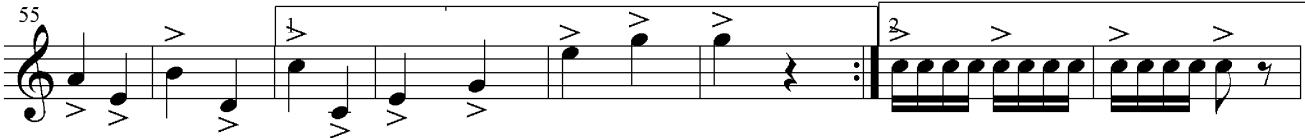

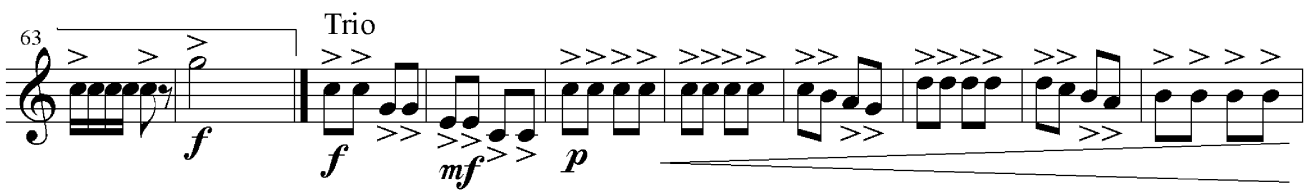

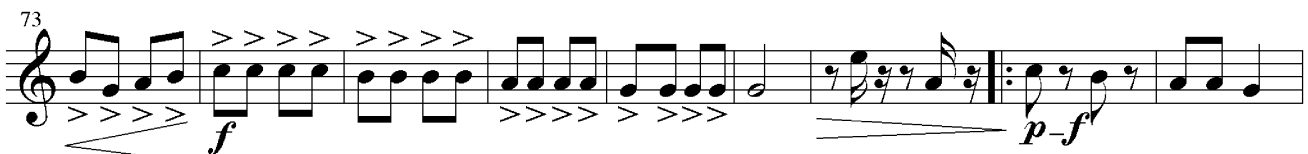
(g) Part III 


\section{Virus in Zutendaal}

Part IV Bb
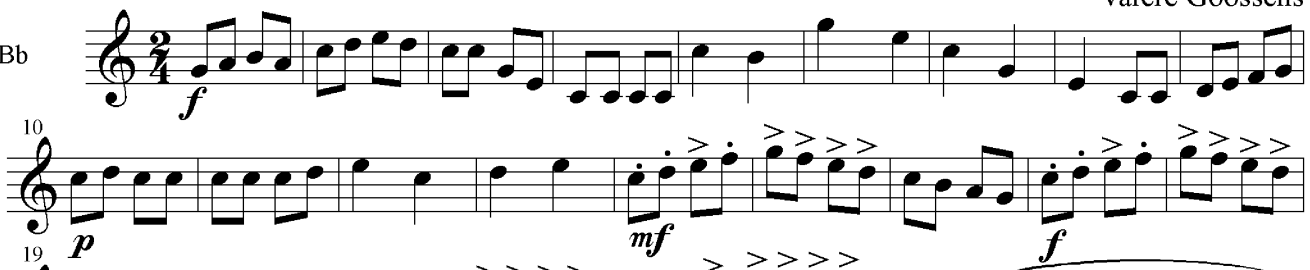

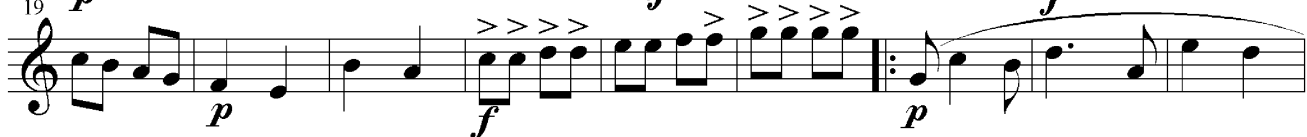
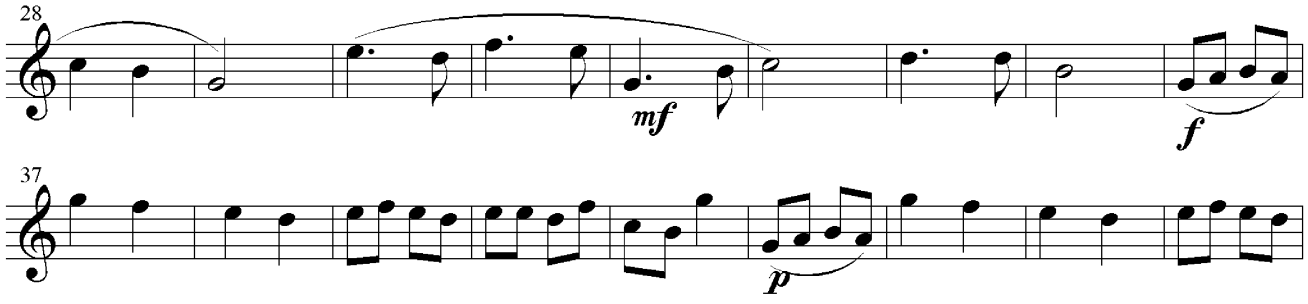

$\overbrace{0}^{46}$

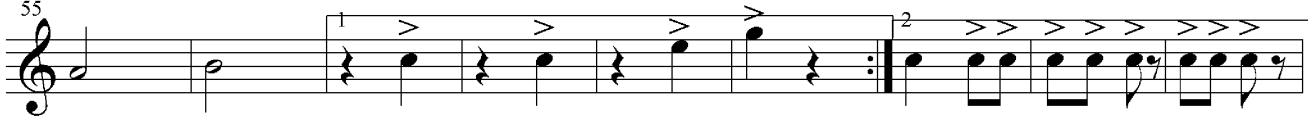

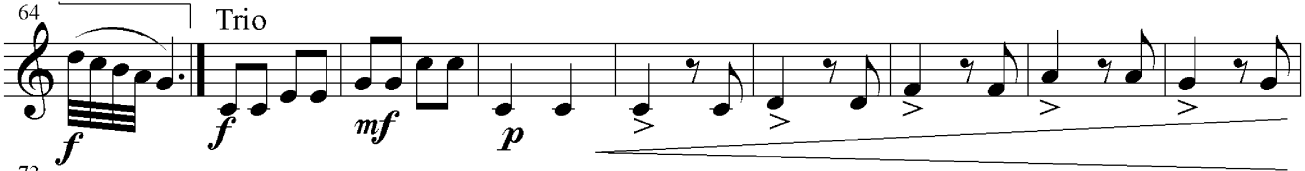

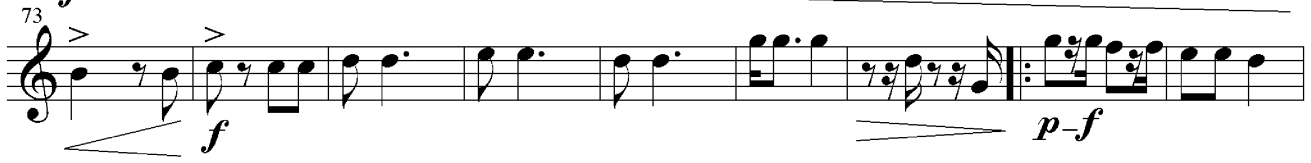

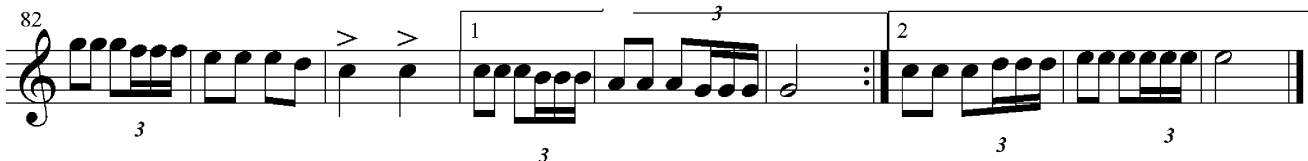


